United States Department of Commerce Technology Administration

National Institute of Standards and Technology

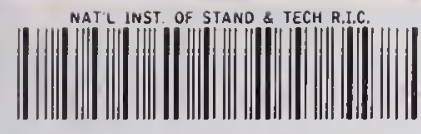

A】】】ロ3 965924

NIST

PUBLICATIONS

NIST Special Publication 366

Supplement 4

\title{
Bibliography on Atomic Line Shapes and Shifts \\ (July 1978 through March 1992)
}


he National Institute of Standards and Technology was established in 1988 by Congress to "assist industry in the development of technology ... needed to improve product quality, to modernize manufacturing processes, to ensure product reliability ... a and to facilitate rapid commercialization ... of products based on new scientific discoveries."

NIST, originally founded as the National Bureau of Standards in 1901, works to strengthen U.S. industry's competitiveness; advance science and engineering; and improve public health, safety, and the environment. One of the agency's basic functions is to develop, maintain, and retain custody of the national standards of measurement, and provide the means and methods for comparing standards used in science, engineering, manufacturing, commerce, industry, and education with the standards adopted or recognized by the Federal Government.

As an agency of the U.S. Commerce Department's Technology Administration, NIST conducts basic and applied research in the physical sciences and engineering and performs related services. The Institute does generic and precompetitive work on new and advanced technologies. NIST's research facilities are located at Gaithersburg, MD 20899, and at Boulder, CO 80303. Major technical operating units and their principal activities are listed below. For more information contact the Public Inquiries Desk, 301-975-3058.

\section{Technology Services}

- Manufacturing Technology Centers Program

- Standards Services

- Technology Commercialization

- Measurement Services

- Technology Evaluation and Assessment

- Information Services

\section{Electronics and Electrical Engineering} Laboratory

- Microelectronics

- Law Enforcement Standards

- Electricity

- Semiconductor Electronics

- Electromagnetic Fields ${ }^{1}$

- Electromagnetic Technology ${ }^{1}$

\section{Chemical Science and Technology} Laboratory

- Biotechnology

- Chemical Engineering ${ }^{1}$

- Chemical Kinetics and Thermodynamics

- Inorganic Analytical Research

- Organic Analytical Research

- Process Measurements

- Surface and Microanalysis Science

- Thermophysics ${ }^{2}$

\section{Physics Laboratory}

- Electron and Optical Physics

- Atomic Physics

- Molecular Physics

- Radiometric Physics

- Quantum Metrology

- Ionizing Radiation

- Time and Frequency

- Quantum Physics ${ }^{1}$
Manufacturing Engineering Laboratory

- Precision Engineering

- Automated Production Technology

- Robot Systems

- Factory Automation

- Fabrication Technology

Materials Science and Engineering Laboratory

- Intelligent Processing of Materials

- Ceramics

- Materials Reliability ${ }^{1}$

- Polymers

- Metallurgy

- Reactor Radiation

Building and Fire Research Laboratory

- Structures

- Building Materials

- Building Environment

- Fire Science and Engineering

- Fire Measurement and Research

Computer Systems Laboratory

- Information Systems Engineering

- Systems and Software Technology

- Computer Security

- Systems and Network Architecture

- Advanced Systems

\section{Computing and Applied Mathematics} Laboratory

- Applied and Computational Mathematics ${ }^{2}$

- Statistical Engineering ${ }^{2}$

- Scientific Computing Environments ${ }^{2}$

- Computer Services ${ }^{2}$

- Computer Systems and Communications ${ }^{2}$

- Information Systems

\footnotetext{
${ }^{1}$ At Boulder, CO 80303.
}

${ }^{2}$ Some elements at Boulder, CO 80303. 


\section{Bibliography on Atomic Line Shapes and Shifts}

(July 1978 through March 1992)

J. R. Fuhr and A. Lesage *

Atomic Physics Division

Physics Laboratory

National Institute of Standards and Technology

Gaithersburg, MD 20899

January 1993

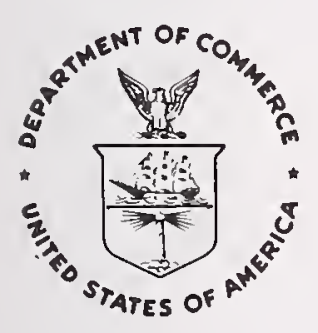

U.S. Department of Commerce

Ronald H. Brown, Secretary

National Institute of Standards and Technology

John W. Lyons, Director
* Observatoire de Paris Meudon, France 
National Institute of Standards and Technology

Special Publication 366, S4 Natl. Inst. Stand. Technol.

Spec. Publ. 366, S4

296 pages (Jan. 1993)

CODEN: NSPUE2
U.S. Government Printing Office Washington: 1993
For sale by the Superintendent of Documents U.S. Government Printing Office Washington, DC 20402 


\section{CONTENTS}

TITLE AND ABSTRACT $\ldots \ldots \ldots \ldots \ldots \ldots \ldots \ldots \ldots$ vii

A. INTRODUCTION .................... viii

B. ACKNOWLEDGMENTS .................... viii

C. REFERENCES ...................... ix

D. TABLE OF CODE LETTERS AND ABBREVIATIONS .......... ix

E. BIBLIOGRAPHICAL MATERIAL ............... 1

1. LITERATURE REFERENCES OF GENERAL INTEREST . . . . . . . . 1

1.0. GENERAL ARTICLES ON LINE SHAPES AND SHIFTS . . . . . 1

1.1. PRESSURE BROADENING . . . . . . . . . . . . 1

1.1.1. Stark broadening and shifts $\ldots \ldots \ldots \ldots \ldots \ldots \ldots$

1.1.1.1. Hydrogen and hydrogen-like (overlapping) lines 2

1.1.1.2. Isolated lines of neutral spectra . . . . . . . 2

1.1.1.3. Isolated lines of ionic spectra . . . . . . . 2

1.1.1.4. Topics of particular interest:

[Line wings; Effects of collective electric

fields; Asymmetries; Microfield distributions;

Magnetic fields; Turbulent plasmas; Ion

dynamic effects; Plasma polarization shifts;

Stark effect on states above the ionization

threshold, autoionization effects; Small field

limit, fine structure; Relativistic effects;

Dielectronic satellites; Rydberg atoms] . . 3

1.1.2. van der Waals broadening $\ldots \ldots \ldots \ldots \ldots \ldots$

1.1.2.1. Satellite bands . . . . . . . . . . 7

1.1.2.2. Polarization effects ........... 7

1.1.2.3. Fine structure; hyperfine structure . . . . . 8

1.1.3. Resonance broadening $\ldots \ldots \ldots \ldots \ldots \ldots$

1.2. BASIC ARTICLES ON DOPPLER AND NATURAL LINE

SHAPES $\ldots \ldots \ldots \ldots \ldots \ldots \ldots \ldots \ldots \ldots$ 
1.2.1. Doppler broadening and Doppler-free spectroscopy . . . . . 8 8

1.2.2. Natural line broadening . . . . . . . . . . . . 9

1.2.3. Radiation induced broadening $\ldots \ldots \ldots \ldots \ldots \ldots$

1.3. BASIC PAPERS ON INSTRUMENTAL BROADENING, DECONVOLUTION, SUPERPOSITION OF TWO OR MORE SIMULTANEOUSLY ACTING BROADENING MECHANISMS . 9

1.3.1. Determination of instrumental line profiles; techniques for determining line shapes $\ldots \ldots \ldots \ldots \ldots \ldots \ldots$

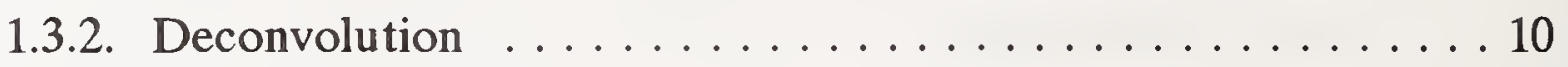

1.3.3. Superposition of broadening mechanisms $\ldots \ldots \ldots \ldots 10$

1.3.4. Multiphoton spectroscopy and saturation methods . . . . . . 11

1.4. IMPORTANT LINE BROADENING APPLICATIONS $\ldots . . .11$

1.4.1. Laser \& maser applications . . . . . . . . . . . 11

1.4.2. Astrophysical applications . . . . . . . . . . . 12

1.4.3. Plasma diagnostics $\ldots \ldots \ldots \ldots \ldots \ldots \ldots \ldots \ldots$

1.4.4. Other applications . . . . . . . . . . . . . 14

1.4.5. Plasma chemistry . . . . . . . . . . . . . . 14

1.5. OTHER TOPICS INVOLVING LINE SHAPES AND SHIFTS . . 14

1.5.1. The line shape in the presence of self absorption; effects of radiative transfer . . . . . . . . . . . . . . . . . 14

1.5.2. Broadening of scattered radiation; redistribution of radiation. 14

1.5.3. Some important papers on molecular line broadening . . . . 15

1.5.4. Miscellaneous topics: [Broadening of $x$-ray lines; Light shifts, relaxation; Zeeman broadening; New anomalous redshifts; Laser field-induced broadening; Charge-exchange effects; Linenarrowing mechanisms $] \ldots \ldots \ldots \ldots \ldots \ldots$

1.6. REVIEW ARTICLES . . . . . . . . . . . . . . . . . . . 16

1.6.1. General line broadening reviews $\ldots \ldots \ldots \ldots \ldots$

1.6.2. Reviews on pressure broadening ........... 16

1.6.2.1. Reviews on Stark broadening ......... 16 
1.6.2.2. Reviews on foreign gas broadening . . . . . 17

1.6.2.3. Reviews on resonance broadening . . . . . 17

1.6.3. Reviews on Doppler broadening and Doppler-free spectroscopy . . . . . . . . . . . . . . . . . . 17

1.6.4. Studies of regularities $\ldots \ldots \ldots \ldots \ldots \ldots \ldots \ldots \ldots$

1.7. REFERENCES ON LINE BROADENING TABLES AND BIBLIOGRAPHIES . . . . . . . . . . . . . . 18

1.7.1. General line broadening tables $\ldots \ldots \ldots \ldots \ldots \ldots$

1.7.2. Pressure broadening tables $\ldots \ldots \ldots \ldots \ldots \ldots \ldots$

1.7.2.1. Special Stark broadening tables ......... 18

1.7.2.2. Special foreign gas broadening tables ...... 18

1.7.3. Doppler and natural line broadening tables $\ldots \ldots \ldots \ldots 18$

1.7.4. Tables of Voigt functions . . . . . . . . . . . 18

1.7.5. Line broadening bibliographies $\ldots \ldots \ldots \ldots \ldots \ldots$

2. A. LITERATURE REFERENCES CONTAINING NUMERICAL DATA:

[All mechanisms except van der Waals] . . . . . . . . . . . . . 19

2. B. LITERATURE REFERENCES CONTAINING NUMERICAL DATA:

[Mechanism: van der Waals] . . . . . . . . . . . . . . . 30

3. CHRONOLOGICAL LISTING OF ALL REFERENCES WITH FULL TITLES . . . . . . . . . . . . . . . . . . . 44

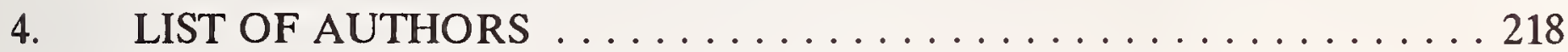

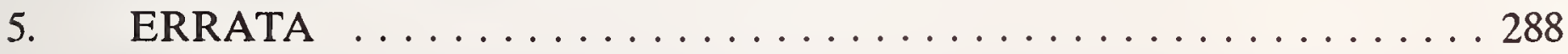





\section{BIBLIOGRAPHY ON ATOMIC LINE SHAPES AND SHIFTS}

(July 1978 through March 1992)

\section{J. R. Fuhr and A. Lesage}

This is the fourth supplement to the original NBS Special Publication 366, Bibliography on Atomic Line Shapes and Shifts (1889 through March 1972). It contains 1964 references and covers the literature from July 1978 to March 1992. As in our previous publications, the bibliography consists of five major parts: (1) Part 1 is a section containing papers of general interest, many without numerical data. These papers are catalogued according to the broadening mechanisms (and further, according to special topics under several of the mechanisms) and as to whether the work is a general theory, a general review, a table of profiles or parameters, a comment on existing work, a study of general experimental measurement techniques, or an experimental effort of general importance. Also included are selected papers on important applications of line broadening and on miscellaneous topics related to atomic spectral line shapes and shifts. (2) In Part 2, all papers containing numerical data are ordered according to element, ionization stage, and broadening mechanism. This section is divided into two parts: Part A--All mechanisms except for van der Waals broadening, and Part B--van der Waals broadening. In the case of foreign gas (van der Waals) broadening, the perturbing species are listed. Furthermore, it is indicated whether the data are experimentally or theoretically derived. (3) While in the two preceding parts of the bibliography the references are listed for brevity by identification numbers only, in Part 3 all references are listed completely by journal, authors, and title. In addition, the papers are arranged by year of publication and alphabetically by the first author's name within the year. (4) Part 4 contains a listing of all authors and their papers, as identified by the reference numbers from Part 3. (5) Part 5 provides corrections and/or additions to the third supplement of the original bibliography.

Key words: Atomic; instrumental broadening; line shapes; line shifts; pressure broadening; resonance broadening; Stark broadening; van der Waals broadening. 


\section{A. INTRODUCTION}

Since 1978, when our last bibliography [1] was published, the Data Center on Atomic Line Shapes and Shifts has continuously monitored the literature and collected relevant papers in the field. This process included scanning approximately 140 journals plus Chemical Abstracts on a weekly basis. This is the fourth supplement to our original bibliography [2], and it contains 1964 papers in the field of atomic spectral line broadening, including all papers that were received by the Data Center between July 1, 1978 and March 31, 1992. These references provide numerical data, reviews, or comments of general interest. Included here are a few older references that were omitted from our earlier publications. As before, we have provided an errata section (Part 5), which consists of corrections and additions to Supplement 3.

\section{B. ACKNOWLEDGMENTS}

We would like to express our great appreciation to Mme. J. Jorand and Mr. F. Leysour of the Observatoire de Paris at Meudon, France. Mme. Jorand diligently entered all references into the database, while Mr. Leysour was the principal programmer and "trouble-shooter." Mr. Leysour helped design the database, as well as organize the sorting and printing of the bibliography. Finally, we gratefully acknowledge the help of Mrs. Helen Felrice of NIST in the preparation of the bibliography. This work was supported in part by the Office of Standard Reference Data at NIST and the CNRS in Paris. 


\section{REFERENCES}

[1] Fuhr, J. R., Miller, B. M., and Martin, G. A., Bibliography on Atomic Line Shapes and Shifts (June 1975 through June 1978), Natl. Bur. Stand. (U.S.), Spec. Publ. 366, Suppl. 3, 83 pages (Dec. 1978).

[2] Fuhr, J. R., Wiese, W. L., and Roszman, L. J., Bibliography on Atomic Line Shapes and Shifts (1889 through March 1972), Natl. Bur. Stand. (U.S.), Spec. Publ. 366, 165 pages (Sept. 1972).

\section{TABLE OF CODE LETTERS AND ABBREVIATIONS}

A. Description

1. T--theoretical method

2. E--experimental method

3. C--comment
B. Language

1. Fr.--French

2. Ger.--German

3. Pol.--Polish

4. Russ.--Russian

5. Span.--Spanish 



\section{E. BIBLIOGRAPHICAL MATERIAL}

\section{UTERATURE REFERENCES OF GENERAL INTEREST}

\subsection{GENERAL ARTICLES ON LINE SHAPES AND SHIFTS}

Theoretical: 3632

\subsection{PRESSURE BROADENING}

Comment: 4527

Combined comments-theoretical: 3217, 4936

Combined experimental-theoretical: 4004

Theoretical: $3139,3227,3228,3270,3342,3410,3514,3554,3572$, $3611,3747,3784,3795,3882,3886,3891,3903,3908$, $3911,3928,4009,4010,4072,4090,4091,4198,4218$, $4228,4229,4246,4283,4285,4296,4335,4368,4390$, $4397,4444,4483,4659,4753,4815,4986,5012$

\subsubsection{Stark broadening and shifts}

Comments: 3872,4157

Combined comments-theoretical:

$3726,3745,3833$, $3934,3997,4375$, 4396,4804

Combined experimental-theoretical: 4563 Theoretical: $3091,3133,3274,3280,3299,3334,3488,3505$, $3587,3593,3594,3665,3692,3741,3747,3750$, $3752,3776,3799,3834,3841,3887,3897,3911$, 3957, 4020, 4027, 4029, 4049, 4121, 4137, 4155, $4185,4187,4204,4214,4220,4237,4289,4290$, $4372,4397,4435,4436,4437,4454,4464,4482$, 
$4491,4546,4566,4568,4586,4593,4628,4704$, $4712,4717,4759,4791,4793,4802,4803,4832$, $4841,4856,4858,4872,4873,4884,4894,4974$, 5014

1.1.1.1. Hydrogen and hydrogen-like (overlapping) lines Comments: $\quad 3730,4379$

Combined comment-experimental-theoretical: 4562

Combined comments-theoretical: $\quad 3726,3745$, 3805,4235

Experimental: $\quad 3322$

Combined experimental-theoretical: 3549

Theoretical: $\quad 3125,3206,3226,3298,3332,3342$, $3458,3576,3602,3662,3718,3719$, $3723,3733,3744,3747,3764,3779$, $3888,3965,3985,4013,4142,4143$, $4238,4253,4300,4303,4349,4387$, 4447, 4448, 4456, 4491, 4517, 4537, 4598, 4672, 4717, 4719, 4762, 4790, 4836, 4865, 4929, 4935. 4987, 5017

\subsubsection{Isolated lines of neutral spectra}

Combined comments-theoretical: $\quad 3162,3745$ Experimental: $\quad 3123,3687$

Theoretical: $\quad 3160,3171,3196,3747,4041,4533$, 4710

1.1.1.3. Isolated lines of ionic spectra

Comment: 3084

Combined comments-theoretical: $\quad 3817,4804$

Combined experimental-theoretical: 3137 
Theoretical:

$3181,3398,3460,3477,3478,3638$, $3640,3660,3671,3844,4027,4270$, $4546,4565,4685,4696,4758,4784$, $4863,4897,4999,5013$

\subsubsection{Topics of particular interest}

A. Line wings

Experimental: $\quad 3152,4269,4661$

Combined experimental-theoretical: $\quad 3222$

Theoretical: 3095, 3227, 3317, 3597, 3889, 4179, $4217,4518,4533,4676,4861$

B. Effects of collective electric fields

Comments: 3426,4118

Combined comments-experimental: 3283,3366 , 3548,3696 , 3729

Combined comments-theoretical: $\quad 3306,3431$, 3484,3485 , 3740,4462

Experimental: $\quad 3242,3467,3480,3558$, $4018,4019,4074,4075,4269$

Combined experimental-comment: 3365

Combined experimental-theoretical: 4165,4443

Theoretical: $3334,3523,3541,3641,3680,3819$, 389.7, 3914, 4495, 4592, 4621, 4767, $4768,4868,4993$

\section{Asymmetries}

Comment: 3730

Combined comments-theoretical: $\quad 3431,3484$ 
Experimental:

$$
\begin{aligned}
& 3152,3248,3534,4136, \\
& 4189,4242,4429,4596, \\
& 4613,4843,4910
\end{aligned}
$$

Combined experimental-theoretical: 4468, 4479,

$$
\text { 4699, } 4902
$$

Theoretical: $3095,3317,3841,3889,4092,4348$, $4598,4714,4903$

D. Microfield distributions

Comment: 3520

Combined comments-theoretical: 3507,3745 ,

3934

Combined experimental-theoretical: 3222,3350

Theoretical: $3390,3504,3527,3562,3668,3669$, $3697,3703,3799,3842,3843,3849$, $3850,3956,3972,4028,4029,4030$, $4031,4050,4052,4092,4100,4127$, $4153,4177,4178,4179,4185,4186$, 4187, 4204, 4234, 4237, 4238, 4256, $4270,4295,4311,4312,4318,4343$, $4369,4370,4415,4422,4433,4454$, $4460,4461,4466,4475,4533,4535$, $4558,4569,4590,4606,4612,4641$, $4702,4717,4719,4721,4759,4767$, $4768,4791,4793,4803,4833,4834$, $4851,4858,4876,4898,4904,4911$, $4927,4934,4949,5026$

E. Magnetic fields

Combined comment-experimental: 3283 
Experimental:

$3205,3284,3433,3645,5002$

Combined experimental-theoretical: 3290

Theoretical: $3252,3441,3527,3541,3719,3724$, 4065, 4207, 4208, 4243, 4356, 4357, 4924,4985

F. Turbulent plasmas

Theoretical: 3523

G. Ion dynamic effects

Comments: $3520,4265,4379,4385$

Combined comments-experimental: 3316, 3666

Combined comments-theoretical: 3402,3726 , 3740,4209 , 4235,4386

Experimental: $\quad 3169,3288,3292,3468$, $3469,3687,3950,3989$, $4078,4079,4374,4626$

Combined experimental-theoretical: 4115,4634 , 4707,4810

Theoretical: $3298,3333,3336,3345,3394,3587$, $3744,3764,3766,3835,3904,4100$, 4208, 4236, 4237, 4238, 4496, 4510, $4511,4516,4517,4552,4580,4641$, $4675,4732,4733,4775,4796,4859$, 4894,4913

H. Plasma polarization shifts

Comments: $3481,3730,4470$

Combined comments-theoretical: $\quad 4375,4564$ 
Experimental: $\quad 3248,3720,3906,4080$, $4136,4166,4499,4910$

Combined experimental-theoretical: 3549,3782 , 4479

Theoretical: $3458,3802,3810,3999,4014,4015$, $4185,4491,4536,4696,4724,4867$. 4899

I. Stark effect on states above the ionization threshold, autoionization effects

Experimental: $\quad 3558,5040$

J. Small field limit; fine structure

K. Relativistic effects

L. Dielectronic satellites

Experimental: $\quad 3618$

Theoretical: $3256,3257,4581$

M. Rydberg atoms

Experimental: $\quad 4395$

Combined experimental-theoretical: 4409

Theoretical: 4194, 4445, 4456, 4610, 4667, 4859, 5018

\subsection{2. van der Waals broadening}

Comments: 3173,3949

Combined comment-experimental: $\quad 3739$

Combined comment-theoretical: 4055

Experimental: $\quad 3560,5037$

Combined experimental-theoretical: $\quad 3509,3627,3668$, 4004, 4082, 4241, 4354,4426 
Theoretical: $3114,3127,3203,3253,3310,3362,3383,3424$, $3518,3557,3597,3610,3611,3721,3785,3800$, $3811,3902,3908,3988,3995,4016,4071,4094$, $4169,4191,4194,4227,4250,4263,4285,4335$, $4368,4378,4392,4413,4509,4540,4541,4658$, $4703,4752,4827,4874,4953,4965$

1.1.2.1. Satellite bands

Combined comment-experimental: $\quad 3465$

Combined comment-theoretical: 4056

Experimental: $\quad 3199,3473,3529,3584,3655,3682$, $3717,3925,4109$

Combined experimental-theoretical: 3168,3207 , 3233,3266 , 3321,3440 , 3583,3688 , 3796, 3862, 4407, 4635, 4842

Theoretical: $\quad 3364,3427,3453,3506,3523,3572$, $3622,3751,3785,4111,4263,4430$, $4541,4660,4852,4853,4854,4862$, $4947,4950,4951$

\subsubsection{Polarization effects}

Combined comments-theoretical: $\quad 3162,4056$

Experimental: $\quad 3417,3606,3939,4167$

Combined experimental-theoretical: 3290,3503 , 4082, 4129, 4543 
Theoretical:

$3274,3314,3628,3891,4057,4071$, 4072, 4191, 4296

1.1.2.3. Fine structure; hyperfine structure

Combined comment-experimental-theoretical: 3921

Combined comment-theoretical: $\quad 3335$

Experimental: $\quad 3311,3413,3417,3486,3710,3769$, $3771,3773,3984,4003,4008,4321$, $4553,4646,4840,4969$

Combined experimental-theoretical: 3355,3416 , 3437,3772 , 3963,4211 , 4502

Theoretical: $\quad 3104,3105,3106,3127,3134,3135$, $3215,3252,3382,3383,3412,3434$, $3435,3483,3516,3552,3610,3677$, $3793,3896,3899,3946,3947,4088$, $4388,4537,4647,4731.4940$

\subsubsection{Resonance broadening}

Theoretical: $3127,3611,4155,4176$

\subsection{BASIC ARTICLES ON DOPPLER AND NATURAL LINE SHAPES}

\subsubsection{Doppler broadening and Doppler-free spectroscopy}

Comment: 3268

Combined comment-experimental: $\quad 4455$

Combined comment-theoretical: 3485

Experimental:

$3297,3330,3349,3369,3384,3418,3419$, $3489,3569,3672,3700,3715,3749,3769$, $3806,3885,3898,3901,4000,4135,4139$, $4167,4323,4367,4421,4542,4607,4754$ 
Combined experimental-theoretical: $\quad 3261,3337,3487$, 4096, 4115, 4543, $4643,4644,4698$, $4744,4773,5039$

Theoretical: $3090,3153,3201,3249,3301,3314,3376,3550$, $3620,3675,3712,3821,3861,4091,4097,4428$, $4511,4827,4963$

1.2.2. Natural line broadening

Theoretical: $3158,3277,3488,3944,4045,4446,4579,4823$, 5015

\subsubsection{Radiation induced broadening}

Combined comment-theoretical: 3109

Experimental: $\quad 3367,3456,3820,3980,4184,4215$

Combined experimental-theoretical: $\quad 3920,3935$

Theoretical: $3131,3462,3543,3643,3652,3707,3738,3775$,

$$
\begin{aligned}
& 3851,3877,3894,3948,3991,3992,4106,4219, \\
& 4228,4353,4410,4771,4985,4993
\end{aligned}
$$

1.3. BASIC PAPERS ON INSTRUMENTAL BROADENING,

DECONVOLUTION, SUPERPOSITION OF TWO OR MORE

SIMULTANEOUSLY ACTING BROADENING MECHANISMS

1.3.1. Determination of instrumental line profiles; techniques for determining line shapes

Combined comments-theoretical: $\quad 3110,3485$

Experimental: $\quad 3083,3097,3251,3259,3329,3381,3404$, $3474,3513,3517,3684,3714,3859,4210$, $4488,4556,4671,4680$

Combined experimental-theoretical: $\quad 3130,3261,3313$, $3358,3359,3360$, 
$3482,3509,3546$,

$4171,4309,4557,4846$

Theoretical: $3082,3129,3167,3218,3220,3254,3258,3305$, $3309,3319,3320,3340,3411,3412,3471,3523$, $3539,3547,3556,3573,3575,3600,3620,3626$, 3706, 3731, 3905, 3912, 3913, 3915, 3951, 3990, $4001,4026,4146,4149,4160,4168,4219,4247$, $4277,4406,4494,4806,4925$

\subsubsection{Deconvolution}

Combined comment-theoretical: 3110

Experimental: $\quad 3087,4297,4726$

Combined experimental-theoretical: $\quad 3244,3308,3358$, $3500,4138,4821,4846$

Theoretical: $3138,3167,3220,3320,3340,3344,3361,3411$, $3470,3620,3648,3756,3812,3883,4034,4081$, 4108, 4147, 4200, 4201, 4314, 4515, 4605, 4608, $4615,4774,4808$

\subsubsection{Superposition of broadening mechanisms}

Comments: $3428,3566,4931$

Combined comments-theoretical:

3577,3857

Experimental: $\quad 3083,3097,3243,3259,3327,3341,3714$, $3859,4297,4959$

Combined experimental-theoretical: $\quad 3244,3429,3482$, $3570,4175,4309,4750$

Theoretical: $3082,3086,3128,3129,3184,3185,3201,3218$, $3272,3285,3304,3319,3340,3375,3377,3407$, $3462,3483,3497,3515,3516,3533,3537,3542$, $3547,3552,3601,3605,3607,3650,3675,3691$, 
$3708,3711,3712,3732,3774,3780,3787,3837$, $3845,3847,3848,3856,4026,4043,4104,4125$, $4150,4159,4168,4212,4264,4277,4293,4299$, $4359,4408,4560,4568,4599,4638,4653,4677$. $4678,4683,4727,4761,4765,4806,4807,4820$, 5004,5029

1.3.4. Multiphoton spectroscopy and saturation methods

Comment: 3178

Experimental:

$3115,3146,3187,3199,3230,3349,3389$, $3405,3417,3418,3422,3489,3561,3569$, $3579,3614,3659,3749,3827,3885,3898$, $3959,4453,4575,4754$

Combined experimental-theoretical: $\quad 3261,3337,3338$, $3408,3487,3509$, $4174,4643,4896$

Theoretical: $3101,3127,3166,3202,3238,3258,3301,3314$, $3412,3531,3881,3911,4097,4188,4792$

1.4. IMPORTANT LINE BROADENING APPLICATIONS

\subsubsection{Laser \& maser applications}

Comments: 3760,4713

Combined comment-experimental: $\quad 4455$

Combined comment-experimental-theoretical: 4562

Combined comment-theoretical: 4901

Experimental:

$3148,3149,3200,3230,3232,3243,3251$, $3269,3312,3343,3367,3389,3393,3405$, $3413,3417,3436,3456,3480,3489,3545$, $3561,3579,3582,3624,3690,3743,3769$, $3820,3846,3853,3980,4042,4132,4323$, 
$4336,4345,4346,4403,4463,4572,4582$, $4728,4843,4941,5037$

Combined experimental-theoretical: $\quad 3165,3222,3261$, $3313,3318,3355$, $3360,3423,3487$, 3503, 3509, 3567, $3592,3619,3651$, $3664,4066,4133$, 4484, 4498, 4559, $4563,4906,4943$

Theoretical: $3090,3166,3189,3307,3363,3528,3543,3565$, $3719,3775,3787,3799,3800,3819,3877,4020$, $4106,4143,4188,4195,4216,4227,4267,4353$, $4476,4491,4585,4600,4609,4647,4658,4759$, $4798,4827,4988,5012$

\subsubsection{Astrophysical applications}

Comment: 4288

Combined comments-theoretical: $\quad 3136,4254,4383,4921$ Experimental: $\quad 4075,4233,4382,4577,4825$

Combined experimental-theoretical: $\quad 3117,3374,3535$, $3536,4165,4409,4747$

Theoretical: $3179,3231,3395,3580,3581,3724,3733,3779$, $3878,3996,4089,4102,4251,4305,4356,4399$, $4400,4401,4587,4591,4593,4637,4715,4811$, $4812,4820,4836,4837,4838,4847,4848,4860$, 4862, 4950, 4951

1.4.3. Plasma diagnostics

Comment: 3289 
Combined comments-experimental: $\quad 3354,3563,4226$

Combined comment-experimental-theoretical: 4562

Combined comments-theoretical: $\quad 3110,3507$

Experimental: $\quad 3087,3122,3126,3174,3176,3192,3209$,

$3236,3243,3245,3248,3264,3265,3267$,

$3273,3296,3322,3331,3343,3387,3396$,

$3397,3400,3404,3415,3430,3457,3463$,

$3466,3472,3502,3519,3564,3612,3667$,

$3672,3676,3687,3690,3701,3743,3803$,

$3806,3853,3865,3880,3952,4000,4076$,

4078, 4117, 4119, 4132, 4135, 4203, 4252,

4257, 4266, 4281, 4284, 4294, 4344, 4345,

4346, 4393, 4412, 4414, 4421, 4463, 4481,

4530, 4572, 4649, 4695, 4743, 4764, 4776,

4824, 4826, 4829, 4866, 4955, 4957, 5002,

$5006,5019,5025,5036$

Combined experimental-theoretical: $\quad 3100,3198,3222$,

$3235,3276,3315$,

$3318,3355,3359$,

$3501,3538,3586$,

3592, 3651, 3653,

$3664,3742,3868$,

3923, 4037, 4066,

$4138,4148,4165$,

4172, 4306, 4319,

4330, 4391, 4431,

$4559,4563,4633$, 
$4773,4831,4922$,

4943,5043

Theoretical: $3086,3125,3191,3219,3225,3325,3420,3462$, $3527,3544,3565,3573,3620,3680,3725,3873$, $3931,3987,4050,4060,4121,4123,4153,4193$, $4216,4461,4467,4491,4576,4612,4719,4790$, $4859,4865,4875,4912,4914,4954$

1.4.4. Other applications

Experimental:

3351

Theoretical: $3091,3116,3161,3274,3324$

1.4.5. Plasma chemistry

Experimental:

$4279,4347,4425,4555,4693,4716$

Theoretical: 4879

1.5. OTHER TOPICS INVOLVING LINE SHAPES AND SHIFTS

1.5.1. The line shape in the presence of self-absorption; effects of radiative transfer

Combined comment-experimental-theoretical: 4562

Combined comment-theoretical: 3968

Experimental: $\quad 3200,3405,3494,4038,4313,4322,4420$, 4735

Combined experimental-theoretical: $\quad 3495,3619,3852$, $4037,4138,4330$, $4391,4431,4750$

Theoretical: $3226,3231,3399,3406$ 3675, 3733, 3931, 3981, $3995,4022,4023,4035,4089,4248,4526,4576$, $4639,4640,4674,4798$

1.5.2. Broadening of scattered radiation; redistribution of radiation Combined comment-experimental-theoretical: 3574 
Combined comments-theoretical: $\quad 3154,4524$

Experimental: $\quad 3381,3606,3824,3863,3939,4523,4624$, 4663,4839

Combined experimental-theoretical: $\quad 3503,3629,4061$, 4066, 4129, 4262, $4355,4502,4548$, 4611,4750

Theoretical: $3089,3092,3103,3158,3274,3357,3444,3445$, $3446,3451,3452,3530,3532,3628,3704,3713$, $3722,3784,3800,3804,3808,3854,3911,3927$, 4020, 4044, 4057, 4071, 4072, 4089, 4227, 4248, $4258,4259,4260,4267,4334,4404,4419,4465$, $4469,4519,4525,4528,4529,4544,4545,4549$, $4594,4639,4640,4673,4674,4749,4753,4777$, $4778,4834,4968,4995,5009$

1.5.3. Some important papers on molecular line broadening Experimental: $\quad 3421,3474,4726$

Combined experimental-theoretical: $\quad 3960,4427,4484$

Theoretical: $3143,3263,3340,3539,3607,3738,3809,3854$, $3962,4141,4198,4474,4984$

1.5.4. Miscellaneous topics

A. Broadening of $x$-ray lines

Experimental: $\quad 3265,4284$

Combined experimental-theoretical: 3318,3423 , 3482,3501 , 3619

Theoretical: $3544,3565,3718,4204$

B. Light shifts; relaxation 
Experimental:

$$
\begin{aligned}
& \text { 3187, з262, з293, з367, } \\
& 3384,3413,3454,3545 \text {, } \\
& 3614,3820,3892,3898 \text {, } \\
& \text { 3922, } 4058
\end{aligned}
$$

Combined experimental-theoretical: 3118,3142 ,

Theoretical: $3153,3301,3302,3307,3362,3383$, $3531,3910,3942,4296$

C. Zeeman broadening

Combined experimental-theoretical: 4664

D. New anomalous redshifts

Combined comment-theoretical: 3392

E. Laser field-induced broadening

Experimental: $\quad 3455$

F. Charge-exchange effects

Combined experimental-theoretical: 4067

G. Line-narrowing mechanisms

Theoretical: 4763

1.6. REVIEW ARTICLES

1.6.1. General line broadening reviews $3108,3255,3623$

Theoretical: 3410,4674

1.6.2. Reviews on pressure broadening $3508,4107,4550,4742,4818,4880,4888,4972$

Comment: 3760

Theoretical: 3725,3881

1.6.2.1. Reviews on Stark broadening 
$3147,4196,4197,4310,4603,4782,4880,4917$

Comment: 3520

Experimental: $\quad 4916$

Combined experimental-theoretical: 3124,3234

Theoretical: $\quad 3641,3725,3744,4715,4913,4974$

1.6.2.2. Reviews on foreign gas broadening

$3786,3967,4880$

Experimental: $\quad 3582,4373$

Theoretical: $\quad 3902,3908$

1.6.2.3. Reviews on resonance broadening 3728,3967

1.6.3. Reviews on Doppler broadening and Doppler-free spectroscopy

4818

Combined experimental-theoretical: $\quad 3112$

1.6.4. Studies of regularities

3096, 3099, 3213, 3237, з379, 3380, 3694, 3698, з734, з735,

3737, 3932, 4046, 4785, 4933, 4982, 5010, 5045

Comment: 3893

Combined comment-theoretical: 5011

Experimental: $\quad 3098,3522,3879,4033,4047,4084,4086$, 4358, 4366, 4500, 4631, 4737, 4738, 4740, 4788, 4816, 4878, 4960, 4979, 4996, 5034

Combined experimental-theoretical: $\quad 3326,3736,4604$, 4736, 4739, 4756

Theoretical: 3196, 3212, 3553, 3818, 3976, 3977, 3978, 4156, 4158, 4289, 4291, 4292, 4372, 4566, 4886, 4887. $4889,4973,4975,4976$ 
1.7. REFERENCES ON LINE BROADENING TABLES AND

BIBLIOGRAPHIES

1.7.1. General line broadening tables

1.7.2. Pressure broadening tables

1.7.2.1. Special Stark broadening tables 4046, 4196, 4197, 4917, 5045

Theoretical: $\quad 4041,4342,4357,4533,4684,4786$, $4837,4855,4882,4883,5031,5032$

1.7.2.2. Special foreign gas broadening tables 3786

1.7.3. Doppler and natural line broadening tables

1.7.4. Tables of Voigt functions

Theoretical: 4150

1.7.5. Line broadening bibliographies

$3172,4888,4972,5028$ 
2. A. LITERATURE REFERENCES CONTAINING NUMERICAL DATA.

All mechanisms except van der Waals.

Element, mechanism, type, reference number as in part 3 .

Al I

Stark

E

3291,3386 , 3646

$\mathrm{E}, \mathrm{T}$

3792,4093

$\mathrm{T}$

3406

Al II

Stark

E

3699,4602

E, T

3736,4371

$\mathrm{T}$

4437

Al III

Stark

$\mathrm{T}$

3212,3460 ,

3640,3750 ,

4685

Al IV

Stark

$\mathrm{T}$

3752

Stark

$\mathrm{T}$

3544

Al X

Stark

$\mathrm{T}$

3544

Al IX
A1 XI

Stark

E

4824

$\mathrm{T}$

3544,3884 , 4873

Al XII

Stark

C.

4670

E

4257

$\mathrm{E}, \mathrm{T}$

3276

$\mathrm{T}$

3544,3799 , 4767, 4768, 4863

Stark-Doppler $\mathrm{T}$

4767

Al XIII

Stark

C

4670

C, T

4235

E

4053, 4203, 4257

E, T

3501
$\mathrm{T}$

3188,3300 , 3544,4187 ,

4256,4552

Ar I

Resonance

E

3192,3909 , $4616 ; 4870$

E, T

4098

T

4230

Stark

E

3387,3388 , 3969,4032 , 4033,4120 , 4192, 4316, 4501, 4596, 4649, 4655, 4656, 4657, 4766, 4770, 4805, 4864, 4923,4956 , 5000

E, T

$3591,37.16$, 4468, 4756, 4902

$\mathrm{T}$

4230,4280 , 4464,4832

Ar II

Stark

E

3152,3180 , 3248,3461 , 3906,4202 ,
4366, 4394, 4500, 4649, 4657, 4755, 4787,4813

E, T. 3137,4492 , 4814

$\mathrm{T}$

3750,4437 , 4439,4440

Ar III

Stark

E

3248,4738

E, T

4604,4915

$\mathrm{T}$

3279,3281 ,

3460,3640 , 3670,4565 , 4685

Ar IV

Stark

E

4738

E, T

4905,4915

$\mathrm{T}$

3279,3281 , 3460,3640 , 3670,4565 , 4685

Ar XII

Stark

E, T

4134 
Al1 mechanisms except van der Waals.

Element, mechanism, type, reference number as in part 3 .

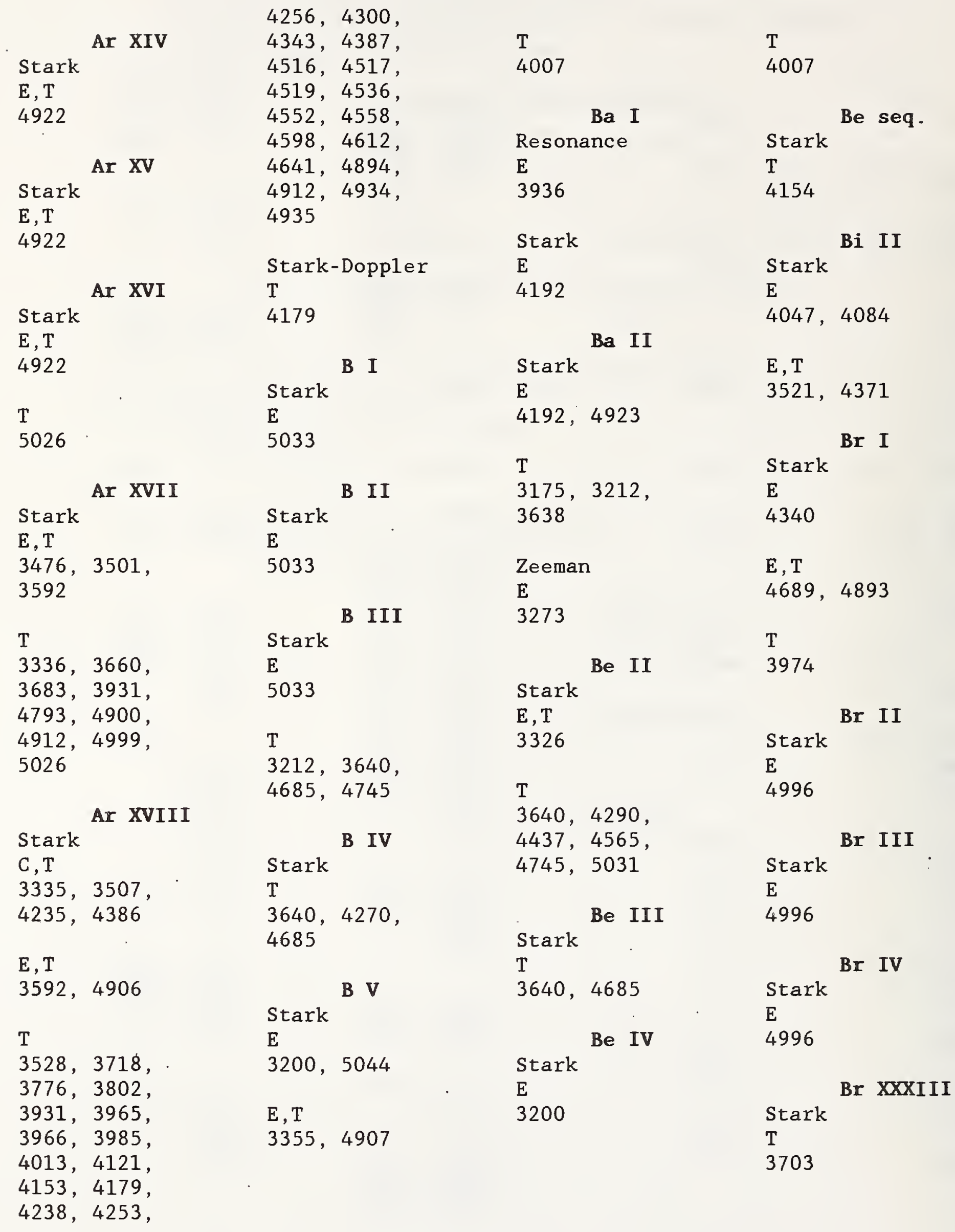


All mechanisms except van der Waals.

Element, mechanism, type, reference number as in part 3.

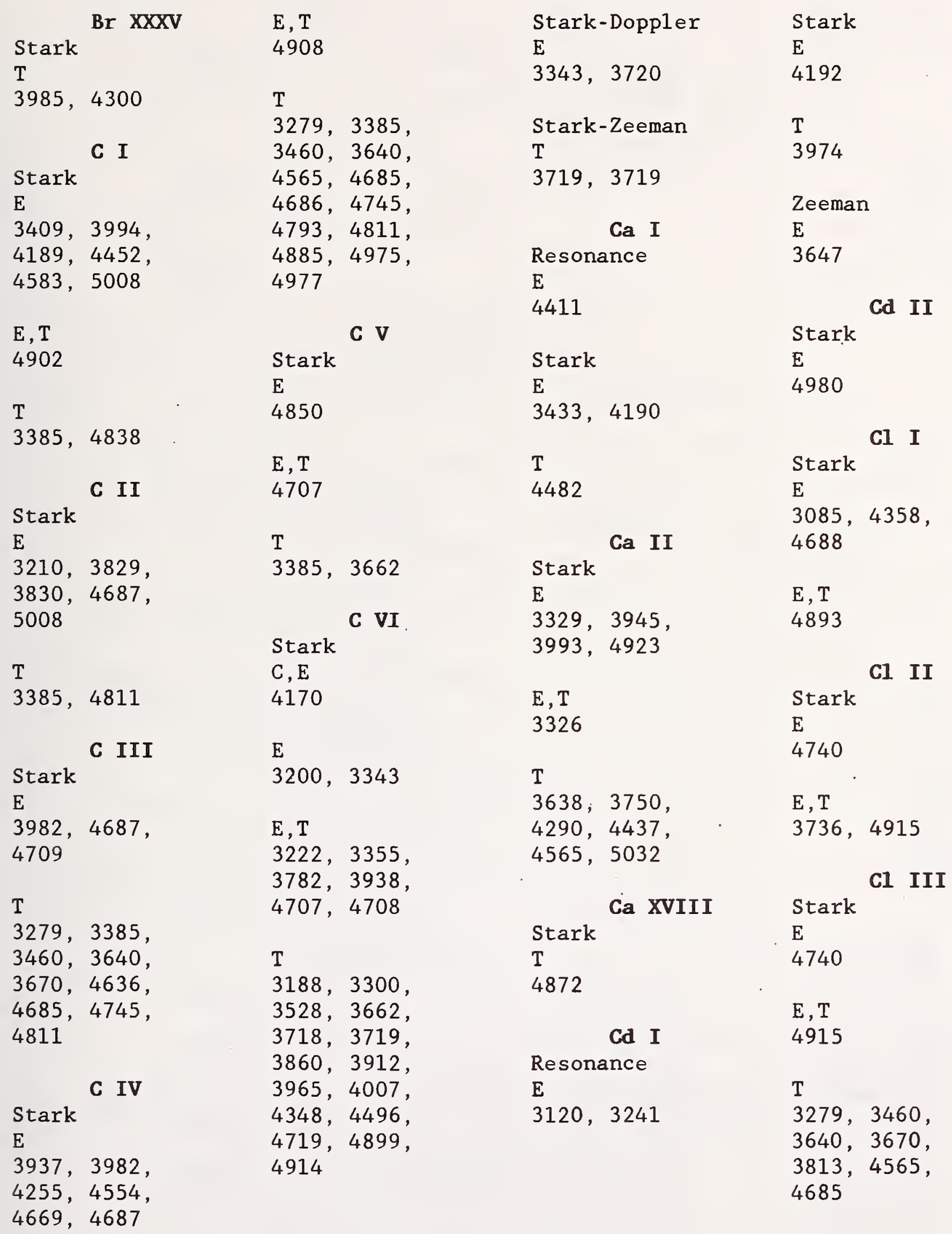


All mechanisms except van der Waals.

Element, mechanism, type, reference number as in part 3.

CI IV

Stark

E

4740

$\mathrm{T}$

3640,4685

CI XVII

Stark

$\mathrm{T}$

4954

Co I

Stark

E

4083,4223

Cr I

Stark

E

3466

Cr II

Stark

E

4048,4224

Cs I

Resonance

E

3190,3356 ,

3418,3783 ,

4666,4772

$\mathrm{E}, \mathrm{T}$

3233,3583

$\mathrm{T}$

3498,3526

Resonance-Doppler

E

3783
Stark

E

3699,3871 ,

4252,4344 ,

4381,4666 ,

4706,4751 ,

4772

E, T

4371

$\mathrm{T}$

3196

Stark-Resonance

$\mathrm{T}$

4252

$\mathrm{Cu}$ I

Line broadening

E

5040

Stark

E

4192, 4298,

4365,4622

E, T

4831

T

4472,4793

Stark-Zeeman

E

5025

Cu II

Stark

$\mathrm{E}$

4298, 4622,

4835
$\mathrm{Cu}$ IV

Stark

$\mathrm{T}$

4783

D I

Stark

C, E

3316

E

3126,3287 ,

3463,3642 ,

3952 , 3989 ,

4626,4830

E, T

3100,4895

Eu I

Resonance

E

4512

F I

Stark

E

4481,4688

E, T

4113, 4893

$\mathrm{T}$

4434

F II

Stark

E.

4979

E, T

3736

$\mathrm{T}$

3640,3670
F III

Stark

E

4740,4979

T

4685

F IX

Stark

C, E, T

4562

E, T

3355

F VII

Stark

E

4095

T

4619, 4714, 4758

F VIII

Stark-Doppler

$\mathrm{E}, \mathrm{T}$

3482

Stark

E

3294,4920 , 4923

Fe II

Stark

$\mathrm{E}$

4923

Fe XV

Stark

$\mathrm{T}$

3496 
Al1 mechanisms except van der Waals.

Element, mechanism, type, reference number as in part 3 .

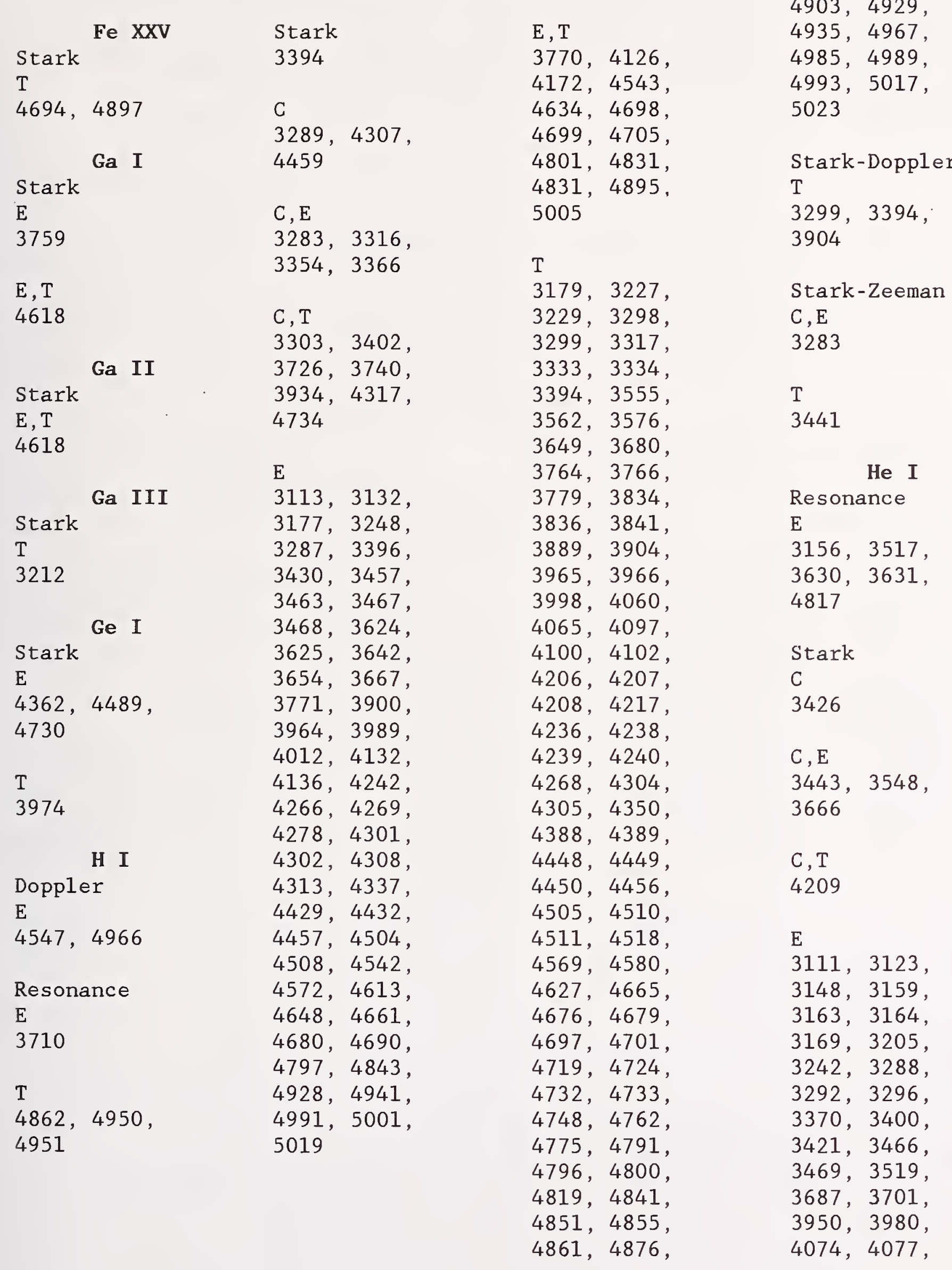


All mechanisms except van der Waals.

Element, mechanism, type, reference number as in part 3 .

4078,4079

4112,4117 ,

4249,4374 ,

4405,4522 ,

4799, 4849,

4938,5007 ,

5024

$\mathrm{E}, \mathrm{T}$

3350,3359 ,

3360 , 3368,

3538,3653 ,

4498, 4810,

4948

$\mathrm{T}$

3133,3278 ,

3282,3334 ,

3345,3432 ,

3598,3603 ,

3765,3791 ,

3801,3816 ,

3878,3976 ,

3977,3978 ,

4156, 4158,

4287, 4435,

4436, 4621,

4675,4786 ,

4793, 4838,

4876,4881

Stark-Zeeman

E

3284

Zeeman

E

5002

He II
Doppler
C,E
3563,3573
Stark
C
3493

C, E T

$3563,4068 \quad 3622,4103$

E

3094, 3197 ,

3221,3400 ,

3612,3803 ,

3840,4080 ,

4131,4166 ,

4221, 4255,

4414, 4418,

4499,4617 ,

4695,4711 ,

4723,4822

$\mathrm{E}, \mathrm{T}$

3315,3538 ,

3549,4794

$\mathrm{T}$

3332,3593 ,

3594,3778 ,

3802,3835 ,

3965,3999 ,

4092, 4451,

4521,4665 ,

4697, 4724,

4732, 4762,

4836,4837 ,

4867, 4871,

4929,4942 ,

5017

Hg I

Resonance

C

3447

E

3328,3571 , 4503

E, T

3440,4502
Stark

E

4038

E, T

3970,4891

$\mathrm{T}$

3974,4103

Zeeman

E

3647

Hg II

Stark

E, T

4891

I I

Resonance

$\mathrm{E}$

3389

Stark

E

4788

E, T

4893

I II

Stark

E

4919

$\begin{array}{ll}\text { Stark } & \text { I III } \\ \text { E } & \\ 4919 & \end{array}$

I LIII

Stark

$\mathrm{T}$

3985,4300

In I

Stark

E, T

4618

In II

Stark

$\mathrm{E}, \mathrm{T}$

4618

In III

Stark

$\mathrm{T}$

3212

K I

Resonance

E

3749

E, T

4326

$\mathrm{T}$

3498,3526 ,

3858,4610

Stark

C

4315

C, T

4338

E

3098,3433 , 4182,4183

$\mathrm{T}$

3196,4438 , 4567,4883 
All mechanisms except van der Waals.

Element, mechanism, type, reference number as in part 3.

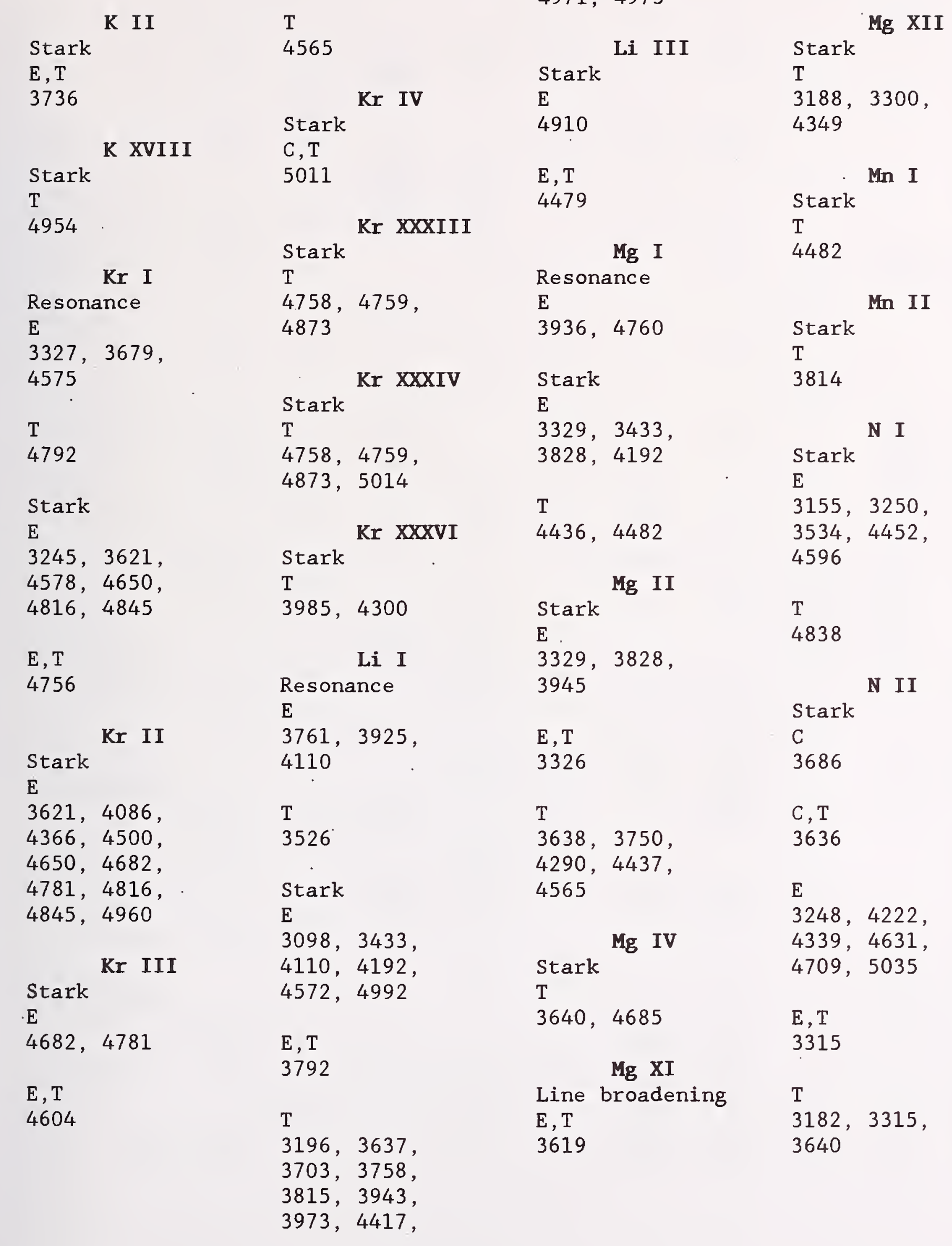


All mechanisms except van der Waals.

Element, mechanism, type, reference number as in part 3 .

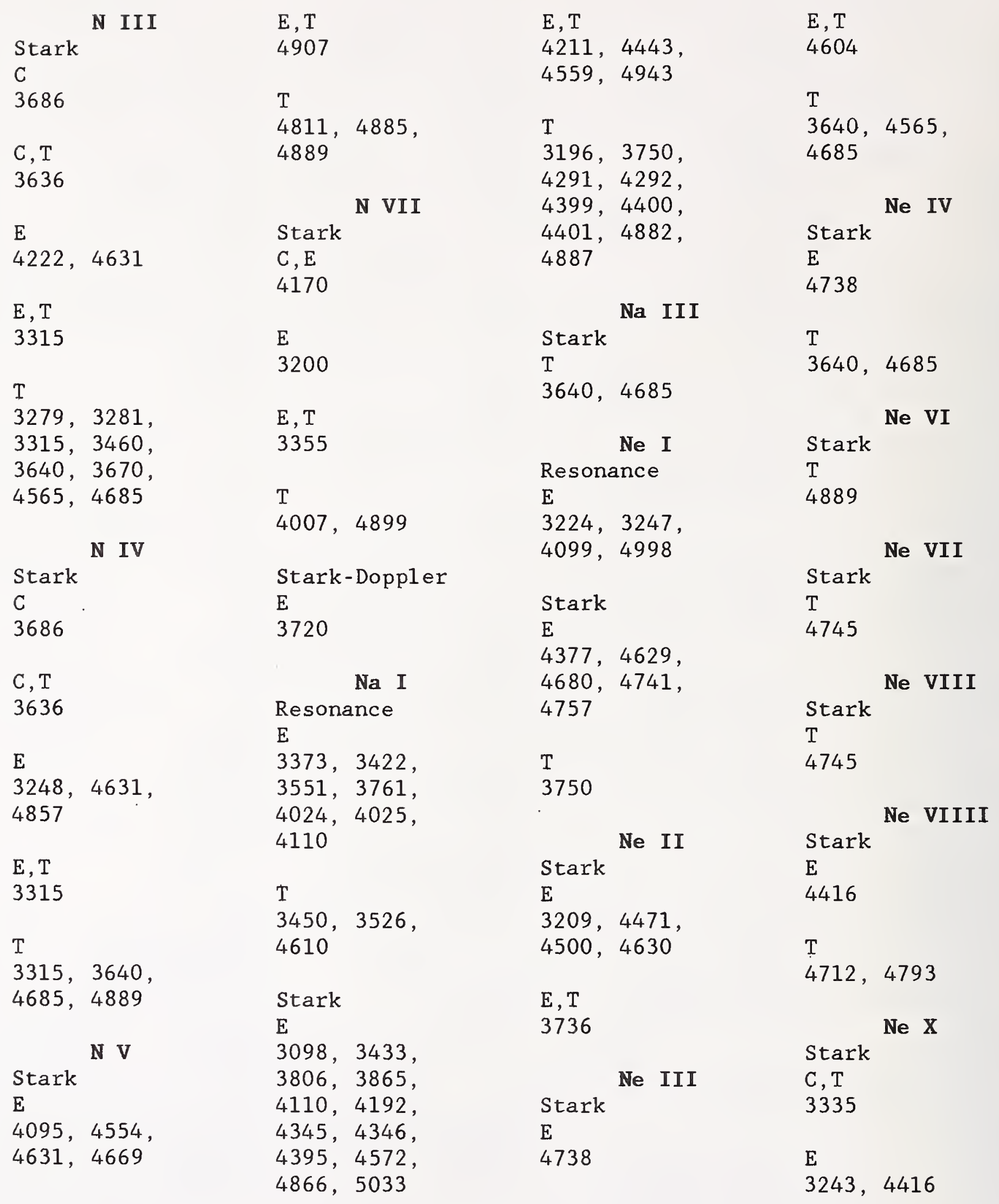


All mechanisms except van der Waals.

Element, mechanism, type, reference number as in part 3 .

\begin{tabular}{|c|c|c|c|c|c|}
\hline $\mathrm{E}, \mathrm{T}$ & & $\mathrm{T}$ & & $\mathrm{T}$ & $\mathrm{Pb}$ II \\
\hline 3423, & 3501 & 3279 , & 3281 & 3188,3300 , & Stark \\
\hline 4906 & & 3460 & 3479 & 4899 & \\
\hline $\mathrm{T}$ & & $\begin{array}{l}3635, \\
3670\end{array}$ & $\begin{array}{l}3640 \\
4565\end{array}$ & P I & 4047,4084 , \\
\hline 3188, & 3300 & 4685 & & Stark & $43 / 6$ \\
\hline 3332 , & 3527 & & & & $E, T$ \\
\hline 3528, & 3565 & & o IV & 4358 & 3347,4371 \\
\hline 3718, & 3802 & Stark & & & \\
\hline 3810 & 4013 & & & P II & $\mathbf{R b ~ I}$ \\
\hline 4123, & 4153 & 4737 & & Stark & Line broadening \\
\hline 4179, & 4214 & & & & $E, T$ \\
\hline 4256, & 4348 & T & & 4047, 4084, & 3495 \\
\hline 4491, & 4516 & 3640 & 4685 & 4358 & \\
\hline 4536 & & & & $E, T$ & $\begin{array}{l}\text { Resonance } \\
3569\end{array}$ \\
\hline Stark & -Doppler & & $0 \mathrm{~V}$ & 3736,4371 & \\
\hline E & & Stark & & & $\mathrm{C}, \mathrm{T}$ \\
\hline 3243 & & & & P III & 4055 \\
\hline & & 4737 & & Stark & \\
\hline T & & & & $\mathrm{T}$ & $\mathrm{E}$ \\
\hline 4179 & & $\begin{array}{l}\mathrm{T} \\
4745,\end{array}$ & 4889 & 3640,4685 & $\begin{array}{l}3190,3356, \\
3403,3419,\end{array}$ \\
\hline & $0 \mathrm{I}$ & 5013 & & P IV & 3569,3749 , \\
\hline Stark & & & & Stark & 3933,4064 , \\
\hline E & & & $0 \mathrm{VI}$ & & 4324 \\
\hline 3994, & 4583 & $\begin{array}{l}\text { Stark } \\
\text { E }\end{array}$ & & 3640,4685 & $E, T$ \\
\hline $\begin{array}{l}\mathrm{T} \\
4662,\end{array}$ & 4838, & 4095, & 4669 & $\begin{array}{r}\mathrm{Pb} \mathrm{I} \\
\text { Resonance }\end{array}$ & 3583 \\
\hline 4859 & & $\mathrm{~T}$ & & $\mathrm{E}$ & $\mathrm{T}$ \\
\hline & 0 II & $\begin{array}{l}4745, \\
4885\end{array}$ & $\begin{array}{l}4811 \\
4889\end{array}$ & 4983 & $\begin{array}{l}3526,3895 \\
4610\end{array}$ \\
\hline Stark & & & & Stark & \\
\hline E & & & 0 VIII & & Stark \\
\hline 4737 , & 4981 & $\begin{array}{l}\text { Stark } \\
C, E\end{array}$ & & 4376,4835 & $\begin{array}{l}\mathrm{E}, \mathrm{T} \\
3326\end{array}$ \\
\hline $\mathrm{T}$ & & 4170 & & $E, T$ & \\
\hline 3479 & 3639 & & & 3347 & $\mathrm{~T}$ \\
\hline 3670 & 3818 & $\begin{array}{l}E \\
3200\end{array}$ & & & 3212,3974 \\
\hline & 0 III & & & 3974 & S I \\
\hline Stark & & $\mathrm{E}, \mathrm{T}$ & & & Stark \\
\hline $\begin{array}{l}E \\
4737\end{array}$ & & 3355 & & & $\begin{array}{l}\mathrm{E} \\
3994,4358,\end{array}$ \\
\hline & & & & & 4393,4481 \\
\hline
\end{tabular}


A11 mechanisms except van der Waals.

Element, mechanism, type, reference number as in part 3 .

S II

Stark

$\mathrm{E}$

4282,4358 , 4481,4890

$\mathrm{E}, \mathrm{T}$

3736,4915

S III

Stark

E

3211,4890

$\mathrm{E}, \mathrm{T}$

3371

$\mathrm{T}$

3460,3478 ,

3640,3670 ,

3813,4565 ,

4685

$\begin{array}{ll}\text { Stark } & \\ \text { E } & \end{array}$

3211

E, T

3371

$\mathrm{T}$

3460,3478 ,

3640,3670 , 3813,4565 , 4685

Sb II

Stark

E

4047,4084

E, T

4371
Si I

Stark

E, T

3374,3792

Si II

Stark

E

3151,3214

3869,4054 ,

4926

$\mathrm{T}$

3975,4715 , 4811

Si III

Stark

E

3869,5034

$\mathrm{T}$

3279,3460 ,

3640 , 3975,

4565,4685 ,

4811,4889

Stark

Si IV

E

5034

$\mathrm{T}$

3279,3460 , 3640,3750 , 4565, 4685, 4811,4976 , 4978,5013

Zeeman

$\mathrm{E}, \mathrm{T}$

4664
Si XIII

Stark

$\mathrm{E}, \mathrm{T}$

3318,3501

$\mathrm{T}$

3334,3336 ,

4092

Si XIV

Stark

E, T

3501

$\mathrm{T}$

3188,3300 ,

3332,4092

Sn I

Stark

E

3348

$\mathrm{T}$

3974

E

3348,4047 ,

4084, 4892

E, T

4371

$\mathrm{T}$

$3477, \quad 3670$

Sr I

Stark

E

4192

Stark-Doppler

E

3494
Stark

E

3329,4192 , 4923

$\mathrm{T}$

3212,3638 ,

3640

Stark-Doppler

E

3494

Stark

$\mathrm{T}$

3814

Stark

$\mathrm{E}, \mathrm{T}$

4507

Stark

$\mathrm{T}$

3703

T1 I

Doppler

E

3341

Resonance

E

3121,3208 , 3571

Stark

$\mathrm{T}$

3212
Ti IV

Ti $X X$

T1 III

Ti II 
A11 mechanisms except van der Waals.

Element, mechanism, type, reference number as in part 3 .

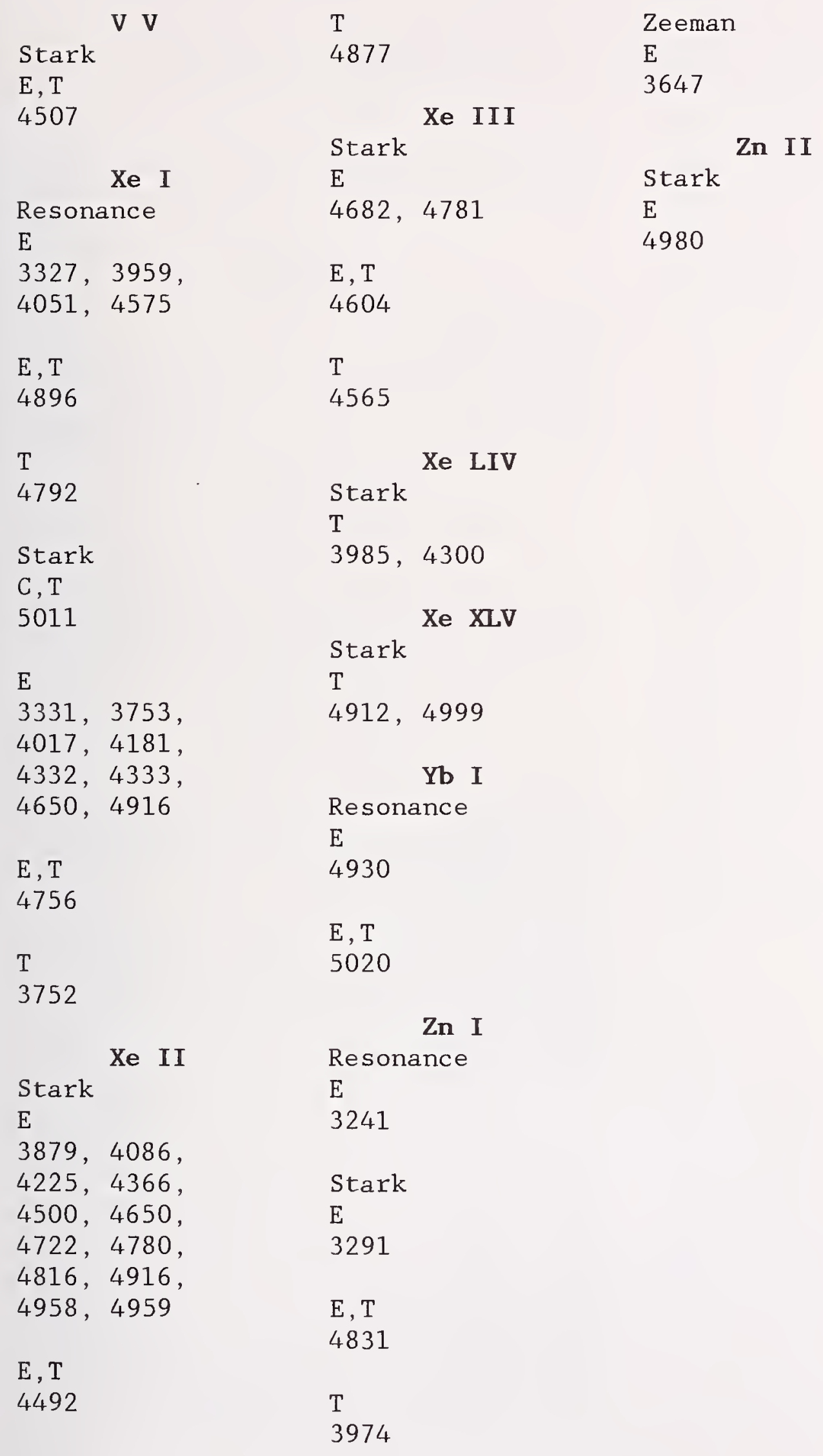




$$
\text { Mechanism : van der Waals. }
$$

Perturbed element; pertubing element; reference number as in part 3 .

\section{$\operatorname{Ag} I$}

E

3596 by Ar, $\mathrm{Kr}$, Xe

\section{Al I}

E

3216 by $\mathrm{He}$, Ar

\section{Ar I}

$\mathrm{C}, \mathrm{T}$

4779 by $\mathrm{He}, \mathrm{Ne}$

E

4486 by Ar

4725 by Ar

3192 by Ar

3909 by Ar

4316 by Ar

4501 by Ar

4616 by Ar

4962 by $\mathrm{Ar}, \mathrm{He}, \mathrm{Ne}$

4531 by $\mathrm{Ar}, \mathrm{Ne}, \mathrm{He}$

4273 by $\mathrm{He}, \mathrm{Ne}, \mathrm{Ar}$

4532 by $\mathrm{He}, \mathrm{Ne}, \mathrm{Ar}$

4870 by $\mathrm{He}, \mathrm{Ne}, \mathrm{Ar}$

4652 by $\mathrm{He}, \mathrm{Ne}, \mathrm{Ar}$

E, T

4124 by Ar
4098 by Ar

4945 by $\mathrm{Ar}, \mathrm{He}$

$\mathrm{T}$

4946 by $\mathrm{He}$

4853 by $\mathrm{He}, \mathrm{Ne}$

4122 by $\mathrm{He}, \mathrm{Ne}, \mathrm{Ar}$

4947 by $\mathrm{Ne}$

B I

$\mathrm{T}$

4520 by $\mathrm{Ne}, \mathrm{Ar}, \mathrm{Kr}$

$\mathrm{Ba} I$

E

3693 by Ar

4004 by Ar

4271 by $\mathrm{Ar}, \mathrm{Kr}$, Xe

4918 by $\mathrm{He}, \mathrm{Ar}$

4244 by $\mathrm{He}, \mathrm{Ar}, \mathrm{Kr}$

3838 by $\mathrm{He}, \mathrm{Ne}, \mathrm{Ar}, \mathrm{Kr}, \mathrm{Xe}$ 3295 by $\mathrm{Kr}$

3578 by $\mathrm{Kr}$

E, T

4262 by Ar

3425 by $\mathrm{Ar}, \mathrm{Kr}, \mathrm{Xe}$

4129 by $\mathrm{Ar}, \mathrm{Xe}$

5022 by $\mathrm{Ba}$

5021 by $\mathrm{He}, \mathrm{Ne}, \mathrm{Ar}, \mathrm{Kr}, \mathrm{Xe}$ 
Mechanism : van der Waals.

Perturbed element; pertubing element; reference number as in part 3.

\section{$\mathrm{T}$}

4392 by $\mathrm{He}, \mathrm{Ar}, \mathrm{Kr}$

4286 by $\mathrm{He}, \mathrm{Ne}$

\section{Ba II}

E

4373 by $\mathrm{Ar}, \mathrm{Ne}$

4654 by $\mathrm{He}$, Ar

Bi I

E

4424 by $\mathrm{He}, \mathrm{Ar}, \mathrm{Xe}$

4553 by $\mathrm{He}, \mathrm{N}_{2}$, Ar, $\mathrm{Xe}$

\section{Br I}

E

3958 by $\mathrm{Br}_{2}, \mathrm{O}_{2}, \mathrm{WF}_{6}, \mathrm{UF}_{6}, \mathrm{C}_{3} \mathrm{~F}_{7} \mathrm{I}$, $\mathrm{CO}_{2}$

\section{Ca I}

E

3352 by Ar

3807 by Ar

4004 by Ar

4561 by $\mathrm{Ar}, \mathrm{Kr}$

4411 by $\mathrm{Ar}, \mathrm{Kr}, \mathrm{Xe}$

4272 by $\mathrm{Ar}, \mathrm{Ne}$

3746 by $\mathrm{He}$

3918 by $\mathrm{He}$

4453 by $\mathrm{He}$

3144 by $\mathrm{He}$, Ar
3656 by $\mathrm{He}, \mathrm{Ar}$

3826 by $\mathrm{He}, \mathrm{Ar}$

4589 by $\mathrm{He}$, Ar, Xe

5041 by $\mathrm{He}, \mathrm{Ne}, \mathrm{Ar}$

3916 by $\mathrm{He}, \mathrm{Ne}, \mathrm{Ar}, \mathrm{Kr}, \mathrm{Xe}$

4006 by $\mathrm{He}, \mathrm{Ne}, \mathrm{Ar}, \mathrm{Kr}, \mathrm{Xe}$

4601 by $\mathrm{He}, \mathrm{Ne}, \mathrm{Ar}, \mathrm{Kr}, \mathrm{Xe}$

4458 by $\mathrm{He}, \mathrm{Ne}, \mathrm{Ar}, \mathrm{Kr}, \mathrm{Xe}$

4754 by $\mathrm{Ne}$

E, T

3604 by air $-\mathrm{C}_{2} \mathrm{H}_{2}$

3627 by Ar

3540 by $\mathrm{Ar}-\mathrm{O}_{2}-\mathrm{H}_{2}$

3919 by $\mathrm{Ar}, \mathrm{Kr}$

4514 by $\mathrm{Ar}, \mathrm{Kr}$, Xe

3535 by $\mathrm{Ar}, \mathrm{Ne}, \mathrm{He}, \mathrm{H}$

4747 by $\mathrm{H}$

4869 by $\mathrm{He}, \mathrm{Ar}$, Xe

3825 by $\mathrm{He}, \mathrm{Ne}, \mathrm{Ar}, \mathrm{Kr}, \mathrm{Xe}$

3917 by $\mathrm{Kr}$

4175 by $\mathrm{Kr}$

3540 by $\mathrm{N}_{2}-\mathrm{O}_{2}-\mathrm{H}_{2}$

$\mathrm{T}$

3203 by Ar

3605 by $\mathrm{Ar}, \mathrm{He}$

4932 by $\mathrm{H}$

3536 by $\mathrm{H}$

5016 by $\mathrm{H}$

4392 by $\mathrm{He}, \mathrm{Ar}, \mathrm{Kr}$

4286 by $\mathrm{He}, \mathrm{Ne}$ 


\section{Mechanism : van der Waals.}

Perturbed element; pertubing element; reference number as in part 3 .

\section{Ca II}

E

3754 by Ar

3144 by $\mathrm{He}, \mathrm{Ar}$

3656 by $\mathrm{He}$, Ar

3826 by $\mathrm{He}$, Ar

$\mathrm{E}, \mathrm{T}$

4004 by Ar

$\mathrm{T}$

3605 by $\mathrm{Ar}, \mathrm{He}$

4729 by $\mathrm{H}$

4485 by $\mathrm{He}$

4614 by $\mathrm{He}$

\section{Cd I}

E

3120 by $\mathrm{Cd}$

3102 by $\mathrm{Cd}, \mathrm{Ne}$

3459 by $\mathrm{He}, \mathrm{Ar}$

3119 by $\mathrm{Xe}$

3475 by $\mathrm{Xe}, \mathrm{Kr}, \mathrm{Ar}, \mathrm{He}, \mathrm{Ne}$

E, T

4426 by $\mathrm{Cd}, \mathrm{Kr}$

$\mathrm{T}$

4380 by $\mathrm{Ar}$

4152 by $\mathrm{Ar}, \mathrm{Kr}, \mathrm{Xe}$
Cd II

E

3789 by Cd

C1 I

E

4840 by $\mathrm{He}, \mathrm{Ar}, \mathrm{Kr}, \mathrm{Xe}, \mathrm{O}_{2}, \mathrm{CO}, \mathrm{CO}_{2}$ $, \mathrm{H}_{2}, \mathrm{~N}_{2}, \mathrm{D}_{2}, \mathrm{Cl}_{2}, \mathrm{I}, \mathrm{Cl}$

Gr I

E

4021 by $\mathrm{C}_{2} \mathrm{H}_{2}-\mathrm{air}$

3378 by $\mathrm{He}, \mathrm{Ar}, \mathrm{N}_{2}, \mathrm{H}_{2}$

Cs I

C, E

3739 by Cs

3465 by $\mathrm{He}$

C, T

3107 by $\mathrm{He}, \mathrm{Ne}, \mathrm{Ar}$

E

3199 by Ar

3717 by Ar

3827 by Ar

3655 by $\mathrm{Ar}, \mathrm{He}, \mathrm{Xe}$

4373 by $\mathrm{Ar}, \mathrm{Ne}$

4011 by $\mathrm{Cs}$

3644 by $\mathrm{H}_{2}$ 
Mechanism : van der Waals.

Perturbed element; pertubing element; reference number as in part 3 .

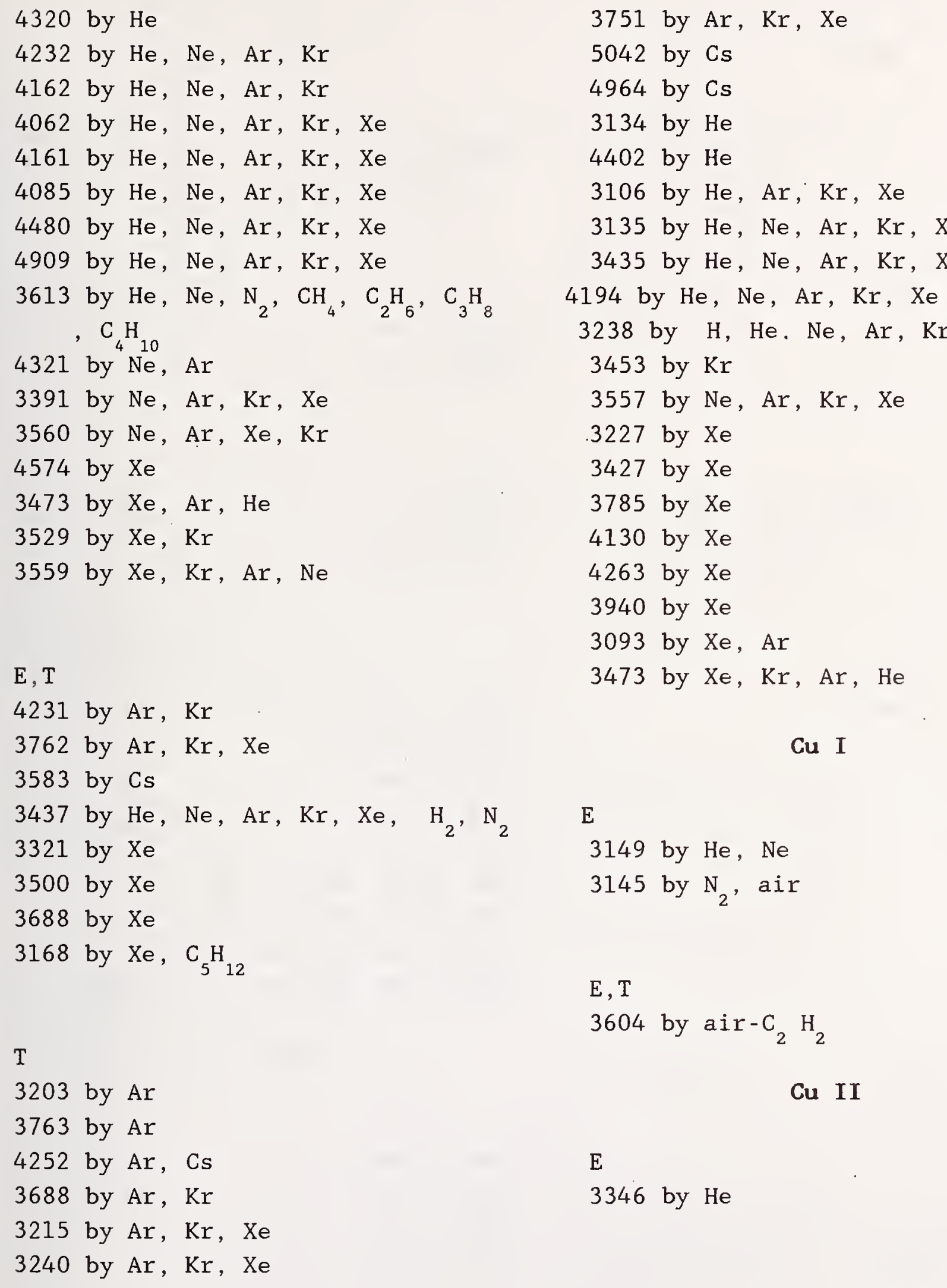

3751 by $\mathrm{Ar}, \mathrm{Kr}$, Xe

5042 by $\mathrm{Cs}$

4964 by Cs

3134 by $\mathrm{He}$

4402 by $\mathrm{He}$

3106 by $\mathrm{He}, \mathrm{Ar}, \mathrm{Kr}$, Xe

4194 by $\mathrm{He}, \mathrm{Ne}, \mathrm{Ar}, \mathrm{Kr}$, Xe 3453 by $\mathrm{Kr}$

3557 by $\mathrm{Ne}, \mathrm{Ar}, \mathrm{Kr}, \mathrm{Xe}$

.3227 by $\mathrm{Xe}$

3427 by Xe

3785 by $\mathrm{Xe}$

4130 by $\mathrm{Xe}$

4263 by $X e$

3940 by $\mathrm{Xe}$

3093 by $\mathrm{Xe}, \mathrm{Ar}$

3473 by $\mathrm{Xe}, \mathrm{Kr}, \mathrm{Ar}, \mathrm{He}$

\section{Cu I}

E

3149 by $\mathrm{He}, \mathrm{Ne}$

3145 by $\mathrm{N}_{2}$, air

$\mathrm{E}, \mathrm{T}$

3604 by air $-\mathrm{C}_{2} \mathrm{H}_{2}$

\section{Cu II}

$\mathrm{E}$

3346 by $\mathrm{He}$

3135 by $\mathrm{He}, \mathrm{Ne}, \mathrm{Ar}, \mathrm{Kr}, \mathrm{Xe}$

3435 by $\mathrm{He}, \mathrm{Ne}, \mathrm{Ar}, \mathrm{Kr}, \mathrm{Xe}$ 3238 by $\mathrm{H}$, He. Ne, $\mathrm{Ar}, \mathrm{Kr}, \mathrm{Xe}$ 


$$
\text { Mechanism : van der Waals. }
$$

Perturbed element; pertubing element; reference number as in part 3 .

Eu I

Ga I

E

4513 by $\mathrm{Ne}$

$\mathrm{T}$

4681 by $\mathrm{He}, \mathrm{Ne}, \mathrm{Xe}$

4965 by $\mathrm{Sr}$

\section{F I}

E

4101 by $\mathrm{He}, \mathrm{Ar}, \mathrm{N}_{2}$

$\mathrm{T}$

4101 by $\mathrm{Ar}$

Fe I

C, T

3136 by $\mathrm{H}$

E

3568 by Ar

E, T

3536 by $\mathrm{H}$, $\mathrm{He}$

$\mathrm{T}$

4584 by $H$

3580 by $\mathrm{H}, \mathrm{H}-\mathrm{He}$
T

3382 by $\mathrm{Ar}, \mathrm{Kr}, \mathrm{Xe}$

H I

E

3417 by $\mathrm{He}$

3769 by $\mathrm{He}$

$\mathrm{E}, \mathrm{T}$

3286 by $\mathrm{H}$

3416 by $\mathrm{He}$

4115 by $\mathrm{He}$

T

4430 by Ar

3271 by Ar II

3104 by $\mathrm{He}$

3946 by $\mathrm{He}$

4940 by $\mathrm{He}$

3106 by $\mathrm{He}, \mathrm{Ar}, \mathrm{Kr}, \mathrm{Xe}$

3135 by $\mathrm{He}, \mathrm{Ne}, \mathrm{Ar}, \mathrm{Kr}, \mathrm{Xe}$

3435 by $\mathrm{He}, \mathrm{Ne}, \mathrm{Ar}, \mathrm{Kr}, \mathrm{Xe}$

3238 by $\mathrm{H}, \mathrm{He}, \mathrm{Ne}, \mathrm{Ar}, \mathrm{Kr}, \mathrm{Xe}$

He I

E

3448 by $\mathrm{He}$ 4087 by $\mathrm{He}$

4632 by $\mathrm{He}$

4937 by $\mathrm{He}$ 
Mechanism : van der Waals.

Perturbed element; pertubing element; reference number as in part 3 .

$\mathrm{T}$

4122 by $\mathrm{He}$

5003 by $\mathrm{He}$

\section{$\mathrm{Hg} \mathrm{I}$}

C

3447 by $\mathrm{Ar}, \mathrm{Kr}$, Xe

E

3727 by $\mathrm{Ar}$

4503 by Ar

4144 by $\mathrm{Ar}, \mathrm{Kr}$

3269 by $\mathrm{Ar}, \mathrm{N}_{2}$

3492 by $\mathrm{He}$

3890 by $\mathrm{He}, \mathrm{Ne}$

3788 by $\mathrm{He}, \mathrm{Ne}, \mathrm{Ar}, \mathrm{Kr}, \mathrm{Xe}$

3589 by $\mathrm{Hg}$

3328 by $\mathrm{Hg}$

3661 by $\mathrm{Kr}$

3571 by $\mathrm{Ne}, \mathrm{Kr}, \mathrm{Xe}$

4002 by Xe

\section{$\mathrm{E}, \mathrm{T}$}

3207 by Ar

3266 by $\mathrm{He}, \mathrm{Ne}, \mathrm{Ar}, \mathrm{Kr}, \mathrm{Xe}$ 3695 by $\mathrm{He}, \mathrm{Ne}, \mathrm{Ar}, \mathrm{Kr}, \mathrm{Xe}$

3157 by $\mathrm{Hg}$

3440 by $\mathrm{Hg}$

4330 by $\mathrm{Hg}$

3970 by $\mathrm{Hg}$
$\mathrm{T}$

3702 by $\mathrm{Ar}, \mathrm{Kr}, \mathrm{Xe}$

4286 by $\mathrm{He}, \mathrm{Ne}$

4852 by $\mathrm{He}, \mathrm{Ne}$

3926 by $\mathrm{He}, \mathrm{Ne}, \mathrm{Ar}, \mathrm{Kr}, \mathrm{Xe}$

3585 by $\mathrm{He}, \mathrm{Ne}, \mathrm{Ar}, \mathrm{Kr}, \mathrm{Xe}$

3506 by $\mathrm{Hg}$

4103 by $\mathrm{Hg}$

\section{I}

E

3983 by $\mathrm{Ar}, \mathrm{O}_{2}, \mathrm{I}_{2}, \mathrm{I}$

4969 by $\mathrm{Ar}, \mathrm{O}_{2}, \mathrm{I}_{2}$

3339 by $\mathrm{He}, \mathrm{O}_{2}, \mathrm{H}^{2}$

4728 by $I$

4069 by $\mathrm{O}_{2}$

$\mathrm{T}$

3339 by $\mathrm{He}$

4969 by $\mathrm{Ne}, \mathrm{Ar}, \mathrm{Kr}, \mathrm{Xe}, \mathrm{O}_{2}$

In I

3223 by $\mathrm{Hg}$

$\mathrm{E}$

3223 by $\mathrm{Hg}$

$\mathrm{E}, \mathrm{T}$

3540 by $\mathrm{Ar}-\mathrm{O}_{2}-\mathrm{H}_{2}$

4163 by $\mathrm{He}, \mathrm{Ne}, \mathrm{Ar}, \mathrm{Kr}, \mathrm{Xe}, \mathrm{H}_{2}, \mathrm{~N}_{2}$

3540 by $\mathrm{N}_{2}-\mathrm{O}_{2}-\mathrm{H}_{2}$ 


\section{Mechanism : van der Waals.}

Perturbed element; pertubing element; reference number as in part 3 .

$\mathrm{T}$

3382 by $\mathrm{Ar}, \mathrm{Kr}$, Xe

K I

E

3673 by Ar

3846 by Ar

3822 by $\mathrm{Ar}$

4970 by Ar

3755 by $\mathrm{Cs}$

3195 by $\mathrm{He}, \mathrm{Ne}, \mathrm{Ar}, \mathrm{Kr}, \mathrm{Xe}, \mathrm{N}_{2}$

4327 by $\mathrm{He}, \mathrm{Ne}, \mathrm{Ar}, \mathrm{Kr}, \mathrm{Xe}$

4328 by $\mathrm{He}, \mathrm{Ne}, \mathrm{Ar}, \mathrm{Kr}, \mathrm{Xe}$

4360 by $\mathrm{N}_{2}, \mathrm{CO}_{2}$

3971 by $\mathrm{Ne}$

4011 by $\mathrm{Rb}$

$\mathrm{E}, \mathrm{T}$

3604 by $\operatorname{air}-\mathrm{C}_{2} \mathrm{H}_{2}$

3867 by Ar

3797 by $\mathrm{Cs}$

3689 by $\mathrm{He}$, Ar

3862 by $\mathrm{He}, \mathrm{Ne}, \mathrm{Ar}, \mathrm{Kr}, \mathrm{Xe}$

3117 by $\mathrm{He}, \mathrm{Ne}, \mathrm{Ar}, \mathrm{Kr}$, Xe

3401 by $\mathrm{He}, \mathrm{Ne}, \mathrm{Ar}, \mathrm{Xe}$

3796 by $\mathrm{K}$

4643 by $\mathrm{K}, \mathrm{Rb}$

3633 by $\mathrm{Ne}$

3634 by $\mathrm{Ne}$

4842 by $\mathrm{Ne}$

4140 by $\mathrm{Rb}$
$\mathrm{T}$

4994 by Ar

3093 by Ar

4952 by $\mathrm{H}$

4540 by $\mathrm{He}, \mathrm{Ne}, \mathrm{Ar}, \mathrm{Kr}, \mathrm{Xe}$

3195 by $\mathrm{He}, \mathrm{Ne}, \mathrm{Ar}, \mathrm{Kr}, \mathrm{Xe}$

4746 by $\mathrm{He}, \mathrm{Ne}, \mathrm{Ar}, \mathrm{Kr}, \mathrm{Xe}, \mathrm{N}_{2}, \mathrm{~K}$

3238 by $\mathrm{H}, \mathrm{He}, \mathrm{Ne}, \mathrm{Ar}, \mathrm{Kr}$, Xe

4213 by $\mathrm{K}$

5030 by $\mathrm{K}, \mathrm{Rb}$

4274 by $\mathrm{Na}$

4964 by $\mathrm{Rb}, \mathrm{K}$

\section{$\operatorname{Kr} I$}

$\mathrm{E}$

3679 by $\mathrm{He}, \mathrm{Kr}$

4122 by $\mathrm{He}, \mathrm{Ne}, \mathrm{Kr}$

$\mathrm{T}$

4946 by $\mathrm{He}$

4853 by $\mathrm{He}, \mathrm{Ne}$

4122 by $\mathrm{He}, \mathrm{Ne}, \mathrm{Ar}, \mathrm{Kr}$

3327 by $\mathrm{Kr}$

4947 by $\mathrm{Ne}$

\section{Li I}

E

3353 by Ar

4114 by $\mathrm{Ar}, \mathrm{Kr}, \mathrm{Xe}$

3790 by $\mathrm{He}$, Ne

3855 by $\mathrm{He}, \mathrm{Ne}, \mathrm{Ar}, \mathrm{Kr}, \mathrm{Xe}$

3685 by $\mathrm{He}, \mathrm{Ne}, \mathrm{Ar}, \mathrm{Kr}, \mathrm{Xe}$ 
Mechanism : van der Waals.

Perturbed element; pertubing element; reference number as in part 3.

3839 by $\mathrm{He}, \mathrm{Ne}, \mathrm{Ar}, \mathrm{Kr}, \mathrm{Xe}$

4534 by $\mathrm{He}, \mathrm{Ne}, \mathrm{Ar}, \mathrm{Kr}, \mathrm{Xe}$

4109 by $\mathrm{Li}$

3925 by $\mathrm{Li}$

$\mathrm{T}$

3605 by $\mathrm{Ar}, \mathrm{He}$

4286 by $\mathrm{He}, \mathrm{Ne}$

E, T

Mg I I

4105 by $\mathrm{Cs}$

3117 by $\mathrm{He}, \mathrm{Ne}, \mathrm{Ar}, \mathrm{Kr}, \mathrm{Xe}$

E

3656 by He, Ar

3826 by $\mathrm{He}$, Ar

$\mathrm{T}$

4952 by $\mathrm{H}$

3093 by $\mathrm{He}$

$\mathrm{T}$

4094 by $\mathrm{He}, \mathrm{Ne}$

3605 by $\mathrm{Ar}, \mathrm{He}$

4540 by $\mathrm{He}, \mathrm{Ne}, \mathrm{Ar}, \mathrm{Kr}, \mathrm{Xe}$

4729 by $H$

3238 by $\mathrm{H}, \mathrm{He}, \mathrm{Ne}, \mathrm{Ar}, \mathrm{Kr}, \mathrm{Xe}$

4485 by $\mathrm{He}$

3896 by $\mathrm{Li}, \mathrm{He}, \mathrm{Ne}$

4213 by $\mathrm{Li}, \mathrm{Na}, \mathrm{K}$

Mn I

\section{Mg I}

E, T

E

3604 by air $-\mathrm{C}_{2} \mathrm{H}_{2}$

4760 by $\mathrm{Ar}$

$\mathrm{Na} I$

4336 by $\mathrm{H}_{2}$

3656 by $\mathrm{He}$, Ar

3826 by $\mathrm{He}$, $\mathrm{Ar}$

4795 by $\mathrm{He}, \mathrm{Ne}, \mathrm{Ar}, \mathrm{Kr}, \mathrm{Xe}$

3178 by $\mathrm{Ar}$

4493 by $\mathrm{H}$

E, T

C, T

4750 by Ar

4383 by $\mathrm{H}$

3425 by $\mathrm{Ar}, \mathrm{Kr}$, Xe

3709 by $\mathrm{He}, \mathrm{Ne}$

4611 by $\mathrm{H}_{2}$, He

E

3115 by Ar 
Perturbed element; pertubing element; reference number as in part 3 .

3170 by Ar

3606 by Ar

3353 by Ar

4008 by Ar

4351 by $\mathrm{Ar}, \mathrm{H}, \mathrm{H}_{2}$

3681 by $\mathrm{Ar}, \mathrm{N}_{2}, \mathrm{H}_{2}, \mathrm{H}_{2} \mathrm{O}, \mathrm{H}_{2}-\mathrm{O}_{2}$

- Ar, $\mathrm{H}_{2}-\mathrm{O}_{2}-\mathrm{N}_{2}^{2}, \mathrm{C}_{2} \mathrm{H}_{2}-\mathrm{O}_{2}-\mathrm{N}_{2}, \quad \mathrm{CO}-\mathrm{CO}_{2}$

3682 by $\mathrm{Ar}, \mathrm{N}_{2}, \mathrm{H}_{2} \mathrm{O}, \mathrm{H}_{2}-\mathrm{O}_{2}-\mathrm{N}_{2}$,

$\mathrm{H} 2-\mathrm{O} 2$ - Ar

3579 by $\mathrm{H}_{2}-\mathrm{O}_{2}-\mathrm{Ar}$

3183 by $\mathrm{H}_{2}-\mathrm{O}_{2}-\mathrm{N}_{2}, \mathrm{H}_{2}-\mathrm{O}_{2}-\mathrm{Ar}, \mathrm{C}_{2} \mathrm{H}_{2}$

$-\mathrm{O}_{2}-\mathrm{N}_{2}$

3524 by $\mathrm{He}$

3781 by $\mathrm{He}$

3773 by $\mathrm{He}$

4477 by $\mathrm{He}$

4478 by $\mathrm{He}$

3373 by $\mathrm{He}$, Ar, $\mathrm{H}_{2}, \mathrm{~N}_{2}$

3551 by $\mathrm{He}, \mathrm{Ar}, \mathrm{H}_{2}^{2}, \mathrm{~N}_{2}^{2}, \mathrm{~N}_{2} \mathrm{O}, \mathrm{CO}, \mathrm{NO}$

3866 by $\mathrm{He}, \mathrm{Ar}, \mathrm{Kr}$

4003 by $\mathrm{He}, \mathrm{Ar}, \mathrm{Kr}$

3146 by $\mathrm{He}, \mathrm{Ar}, \mathrm{N}_{2}$

4828 by $\mathrm{He}, \mathrm{Ar}, \mathrm{Xe}, \mathrm{N}_{2}$

3984 by $\mathrm{He}, \mathrm{N}_{2}$, Ar, Kr

3349 by $\mathrm{He}, \mathrm{Ne}$

3293 by $\mathrm{He}, \mathrm{Ne}, \mathrm{Ar}$

3490 by $\mathrm{He}, \mathrm{Ne}, \mathrm{Ar}, \mathrm{Kr}$, Xe

3449 by $\mathrm{He}, \mathrm{Ne}, \mathrm{Ar}, \mathrm{Kr}$, Xe

3491 by $\mathrm{He}, \mathrm{Ne}, \mathrm{Ar}, \mathrm{Kr}, \mathrm{Xe}$

3525 by $\mathrm{He}, \mathrm{Ne}, \mathrm{Ar}, \mathrm{Kr}, \mathrm{Xe}$

3499 by $\mathrm{He}, \mathrm{Ne}, \mathrm{Ar}, \mathrm{Kr}$, Xe

3262 by $\mathrm{He}, \mathrm{Ne}, \mathrm{Ar}, \mathrm{Kr}$, Xe

3768 by $\mathrm{He}, \mathrm{Ne}, \mathrm{Ar}, \mathrm{Kr}, \mathrm{Xe}$

3715 by $\mathrm{He}, \mathrm{Ne}, \mathrm{Ar}, \mathrm{Kr}, \mathrm{Xe}$

3246 by $\mathrm{He}, \mathrm{Ne}, \mathrm{H}$

3986 by $\mathrm{N}_{2}$

4073 by $\mathrm{N}_{2}^{2}, \mathrm{H}_{2} \mathrm{O}$
3824 by $\mathrm{N}_{2}, \mathrm{Na}_{2}$

3907 by $\mathrm{Ne}$

3590 by $\mathrm{Ne}, \mathrm{Ar}, \mathrm{Xe}$

4595 by $\mathrm{Ne}, \mathrm{Ar}, \mathrm{Xe}$

3658 by $\mathrm{Ne}, \mathrm{Kr}, \mathrm{Xe}$

4624 by $\mathrm{Ne}$, Xe

3659 by $\mathrm{Ne}, \mathrm{Xe}, \mathrm{Kr}$

3372 by NO, $\mathrm{CO}, \mathrm{N}_{2} \mathrm{O}$

4036 by $\mathrm{Rb}$, $\mathrm{Cs}$

3767 by Xe

$\mathrm{E}, \mathrm{T}$

3604 by air $-\mathrm{C}_{2} \mathrm{H}_{2}$

3503 by Ar

3540 by $\mathrm{Ar}-\mathrm{O}_{2}-\mathrm{H}_{2}$

3772 by $\mathrm{He}$

4573 by $\mathrm{He}, \mathrm{Ar}$

3823 by $\mathrm{He}$, $\mathrm{Ne}$, Ar

3588 by $\mathrm{He}, \mathrm{Ne}, \mathrm{Ar}, \mathrm{Kr}, \mathrm{Xe}$

3142 by $\mathrm{He}, \mathrm{Ne}, \mathrm{Ar}, \mathrm{Kr}$, Xe

4082 by $\mathrm{He}, \mathrm{Ne}, \mathrm{Ar}, \mathrm{Kr}, \mathrm{Xe}$

3509 by $\mathrm{He}, \mathrm{Ne}, \mathrm{Kr}$

3570 by $\mathrm{Hg}$

4407 by $\mathrm{Hg}$

4245 by $\mathrm{K}, \mathrm{Rb}, \mathrm{Cs}$

3338 by $\mathrm{Kr}$

3540 by $\mathrm{N}_{2}-\mathrm{O}_{2}-\mathrm{H}_{2}$

3941 by $\mathrm{Ne}$

4174 by $\mathrm{Ne}, \mathrm{Kr}, \mathrm{Xe}$

4623 by $\mathrm{Ne}, \mathrm{Xe}$

4625 by $\mathrm{Ne}, \mathrm{Xe}$

4597 by Xe

$\mathrm{T}$

3203 by Ar 
Mechanism : van der Waals.

Perturbed element; pertubing element; reference number as in part 3.

3275 by Ar

3464 by Ar

Ne I

4809 by Ar

4720 by Ar

C, T

3681 by Ar

4779 by $\mathrm{He}$

4828 by Ar

4173 by $\mathrm{Ar}, \mathrm{Kr}$, $\mathrm{He}, \mathrm{Xe}$

3777 by $\mathrm{Ar}, \mathrm{Kr}, \mathrm{Xe}$

E

3919 by $\mathrm{Ar}, \mathrm{Kr}$, Xe

3140 by $\mathrm{He}$

4827 by $\mathrm{Ar}$, Xe

3595 by $\mathrm{He}-\mathrm{Ne}, \mathrm{Ne}$

4361 by $\mathrm{H}$

4399 by $\mathrm{H}$

4400 by $\mathrm{H}$

3323 by $\mathrm{He}, \mathrm{Ne}$

3616 by $\mathrm{He}, \mathrm{Ne}$

3615 by $\mathrm{He}, \mathrm{Ne}$

4401 by $\mathrm{H}$

4122 by $\mathrm{He}, \mathrm{Ne}$

4953 by $\mathrm{H}$

3979 by $\mathrm{He}, \mathrm{Ne}$

3748 by $\mathrm{He}$

3953 by $\mathrm{He}, \mathrm{Ne}$

4016 by $\mathrm{He}$

3954 by $\mathrm{He}, \mathrm{Ne}$

3899 by $\mathrm{He}$

3864 by $\mathrm{He}, \mathrm{Ne}$

4088 by $\mathrm{He}$

3617 by $\mathrm{He}, \mathrm{Ne}$

3093 by $\mathrm{He}$

4718 by $\mathrm{He}$, Ar

3106 by $\mathrm{He}, \mathrm{Ar}, \mathrm{Kr}, \mathrm{Xe}$

4276 by $\mathrm{He}, \mathrm{Ne}$

4423 by $\mathrm{He}, \mathrm{Ne}$

4952 by $\mathrm{He}, \mathrm{H}, \mathrm{Ne}, \mathrm{Ar}, \mathrm{Kr}, \mathrm{Xe}$

4961 by $\mathrm{He}, \mathrm{Ne}$

3302 by $\mathrm{He}, \mathrm{Ne}, \mathrm{Ar}, \mathrm{Kr}, \mathrm{Xe}$

4473 by $\mathrm{He}, \mathrm{Ne}, \mathrm{Ar}, \mathrm{Kr}$

3260 by $\mathrm{He}, \mathrm{Ne}, \mathrm{He}-\mathrm{Ne}$

3141 by $\mathrm{Ne}$

3832 by $\mathrm{He}, \mathrm{Ne}, \mathrm{Ar}, \mathrm{Kr}, \mathrm{Xe}$

4384 by $\mathrm{Ne}$

4194 by $\mathrm{He}, \mathrm{Ne}, \mathrm{Ar}, \mathrm{Kr}, \mathrm{Xe}$

4551 by $\mathrm{Ne}$

4180 by $\mathrm{Ne}$

4540 by $\mathrm{He}, \mathrm{Ne}, \mathrm{Ar}, \mathrm{Kr}, \mathrm{Xe}$

4087 by $\mathrm{Ne}$

4272 by $\mathrm{Ne}$

4055 by $\mathrm{He}, \mathrm{Ne}, \mathrm{Ar}, \mathrm{Xe}$

4632 by $\mathrm{Ne}$

3238 by $\mathrm{H}, \mathrm{He}, \mathrm{Ne}, \mathrm{Ar}, \mathrm{Kr}$, Xe

4274 by $\mathrm{K}$

4213 by $\mathrm{Na}, \mathrm{K}$

E, T

3364 by $\mathrm{Ne}$

4744 by $\mathrm{He}, \mathrm{Ar}, \mathrm{Ne}$

4731 by $\mathrm{Ne}, \mathrm{Xe}$

3438 by $\mathrm{He}, \mathrm{Ne}$

3372 by NO, CO

3487 by $\mathrm{Ne}$ 


$$
\text { Mechanism : van der Waals. }
$$

Perturbed element; pertubing element; reference number as in part 3 .

3567 by $\mathrm{Ne}$

$\mathrm{T}$

4854 by $\mathrm{He}$

4946 by $\mathrm{He}$

4341 by $\mathrm{He}-\mathrm{Ne}, \mathrm{Ne}$

3088 by $\mathrm{He}, \mathrm{Ne}$

3599 by $\mathrm{He}, \mathrm{Ne}$

4122 by $\mathrm{He}, \mathrm{Ne}$

3439 by $\mathrm{Ne}, \mathrm{He}$

3204 by $\mathrm{Ne}, \mathrm{He}-\mathrm{Ne}$

\section{$\mathrm{Pb} \mathrm{I}$}

E

4199 by air $-\mathrm{C}_{2} \mathrm{H}_{2}$, air $-\mathrm{H}_{2}$ 4983 by $\mathrm{Pb}$

E, T

5038 by $\mathrm{Ar}, \mathrm{He}$

\section{$\mathrm{Rb} \mathrm{I}$}

C

4063 by $\mathrm{He}, \mathrm{Ne}, \mathrm{Ar}, \mathrm{Kr}, \mathrm{Xe}$

C, E, T

3921 by $\mathrm{Ar}, \mathrm{N}_{2}$

E

4441 by $\mathrm{Ar}, \mathrm{He}$

3794 by $\mathrm{CH}$

4011 by $\mathrm{Cs}^{4}, \mathrm{~K}$
3674 by $\mathrm{He}$

4487 by $\mathrm{He}$

4997 by $\mathrm{He}$

3486 by $\mathrm{He}, \mathrm{Ar}$

4442 by $\mathrm{He}, \mathrm{Ar}$

3929 by $\mathrm{He}, \mathrm{Ar}, \mathrm{Xe}$

3933 by $\mathrm{He}, \mathrm{Ne}, \mathrm{Ar}$

3311 by $\mathrm{He}, \mathrm{Ne}, \mathrm{Ar}, \mathrm{Kr}$

3608 by $\mathrm{He}, \mathrm{Ne}, \mathrm{Ar}, \mathrm{Kr}$

3186 by $\mathrm{He}, \mathrm{Ne}, \mathrm{Ar}, \mathrm{Kr}$, Xe

3678 by $\mathrm{He}, \mathrm{Ne}, \mathrm{Ar}, \mathrm{Kr}, \mathrm{Xe}$

4062 by $\mathrm{He}, \mathrm{Ne}, \mathrm{Ar}, \mathrm{Kr}, \mathrm{Xe}$

4325 by $\mathrm{He}, \mathrm{Ne}, \mathrm{Ar}, \mathrm{Kr}, \mathrm{Xe}$

4329 by $\mathrm{He}, \mathrm{Ne}, \mathrm{Ar}, \mathrm{Kr}, \mathrm{Xe}$

4642 by $\mathrm{Ne}, \mathrm{Kr}, \mathrm{H}_{2}$

3569 by $\mathrm{Rb}$

3885 by $\mathrm{Rb}$

3403 by $\mathrm{Rb}$

4116 by $\mathrm{Xe}$

4070 by $\mathrm{Xe}$

3609 by $\mathrm{Xe}, \mathrm{N}_{2}, \mathrm{CH}_{4}$

$\mathrm{E}, \mathrm{T}$

3798 by $\mathrm{He}, \mathrm{Ar}$

3442 by $\mathrm{He}, \mathrm{Ne}, \mathrm{Ar}, \mathrm{Kr}$, Xe

3118 by $\mathrm{N}_{2}$, Ar

3193 by $\mathrm{N}_{2}$, $\mathrm{He}$

4643 by $R b$

$\mathrm{T}$

3215 by $\mathrm{Ar}, \mathrm{Kr}, \mathrm{Xe}$

3240 by $\mathrm{Ar}, \mathrm{Kr}, \mathrm{Xe}$

3134 by $\mathrm{He}$

3106 by $\mathrm{He}, \mathrm{Ar}, \mathrm{Kr}, \mathrm{Xe}$

4939 by $\mathrm{He}, \mathrm{Ar}, \mathrm{Kr}, \mathrm{Xe}$ 
Perturbed element; pertubing element; reference number as in part 3 .

3135 by $\mathrm{He}, \mathrm{Ne}, \mathrm{Ar}, \mathrm{Kr}, \mathrm{Xe}$

3435 by $\mathrm{He}, \mathrm{Ne}, \mathrm{Ar}, \mathrm{Kr}, \mathrm{Xe}$

4746 by $\mathrm{He}, \mathrm{Ne}, \mathrm{Ar}, \mathrm{Kr}, \mathrm{Xe}, \mathrm{N}_{2}, \mathrm{Rb} \quad \mathrm{E}$ 3831 by $\mathrm{He}, \mathrm{Xe}$

E

3832 by $\mathrm{He}, \mathrm{Xe}$

3150 by Ar

4173 by $\mathrm{He}, \mathrm{Xe}$

3656 by $\mathrm{He}$, Ar

3238 by $\mathrm{H}, \mathrm{He}, \mathrm{Ne}, \mathrm{Ar}, \mathrm{Kr}, \mathrm{Xe}$

3826 by $\mathrm{He}, \mathrm{Ar}$

5030 by $\mathrm{K}, \mathrm{Rb}$

3961 by $\mathrm{He}, \mathrm{Ar}, \mathrm{Kr}, \mathrm{Xe}$

4352 by $\mathrm{Kr}$

3939 by $\mathrm{He}, \mathrm{Ne}, \mathrm{Ar}, \mathrm{Kr}, \mathrm{Xe}$

3093 by $\mathrm{Kr}$

4700 by $\mathrm{He}, \mathrm{Ne}, \mathrm{Ar}, \mathrm{Kr}, \mathrm{Xe}$

3324 by $\mathrm{N}_{2}$, $\mathrm{He}$

4005 by $\mathrm{He}, \mathrm{Ne}, \mathrm{Kr}$

4964 by $\mathrm{Rb}, \mathrm{K}, \mathrm{Cs}$

3414 by $\mathrm{He}, \mathrm{Xe}$

3254 by $\mathrm{Xe}$

3930 by $\mathrm{He}, \mathrm{Xe}$

3955 by $\mathrm{Xe}$

4070 by $\mathrm{Xe}$

4275 by $\mathrm{Xe}$

\section{E, T}

Si I

3540 by $\mathrm{Ar}-\mathrm{O}_{2}-\mathrm{H}_{2}$

3663 by Ar, Xe

$\mathrm{E}, \mathrm{T}$

3374 by $\mathrm{H}$

3540 by $\mathrm{N}_{2}-\mathrm{O}_{2}-\mathrm{H}_{2}$

$\mathrm{T}$

3203 by Ar

$\mathrm{T}$

3203 by Ar

4469 by Ar

4506 by Ar

Sm I

4286 by $\mathrm{He}, \mathrm{Ne}$

5018 by $\mathrm{Xe}$

E

4769 by $\mathrm{He}$

Sr II

4398 by $\mathrm{He}, \mathrm{Ar}$

4646 by $\mathrm{He}, \mathrm{Ne}, \mathrm{Ar}, \mathrm{Kr}, \mathrm{Xe}$

E

4645 by $\mathrm{Kr}$

4588 by $\mathrm{Ar}$

3656 by $\mathrm{He}, \mathrm{Ar}$

Sr I

3826 by $\mathrm{He}, \mathrm{Ar}$

4373 by $\mathrm{He}, \mathrm{Ne}, \mathrm{Ar}$

C, T

4056 by Ar, Kr, Xe 
Perturbed element; pertubing element; reference number as in part 3 .

T1 I

\section{E}

3381 by Ar

4363 by Ar

3571 by $\mathrm{Ar}$

4844 by $\mathrm{Ar}, \mathrm{He}$

4205 by $\mathrm{CO}$

3876 by $\mathrm{CO}_{2}$

3510 by $\mathrm{H}_{2}^{2}$

3341 by $\mathrm{H}_{2}$

4620 by $\mathrm{He}$, Ar

4490 by $\mathrm{He}, \mathrm{N}_{2}$

3924 by $\mathrm{He}, \mathrm{Ne}, \mathrm{Ar}, \mathrm{Kr}, \mathrm{Xe}$

4539 by $\mathrm{He}, \mathrm{Ne}, \mathrm{Ar}, \mathrm{Kr}$, Xe

4261 by $\mathrm{He}, \mathrm{Ne}, \mathrm{Ar}, \mathrm{Kr}, \mathrm{Xe}, \mathrm{H}_{2}, \mathrm{~N}_{2}$, $\mathrm{CO}_{2}$

3121 by $\mathrm{He}, \mathrm{Ne}, \mathrm{Ar}, \mathrm{Kr}, \mathrm{Xe}$

3223 by $\mathrm{Hg}$

3875 by $\mathrm{N}_{2}$

4364 by $\mathrm{N}_{2}^{2}$, He

4570 by $\mathrm{Ne}, \mathrm{Ar}$

4571 by $\mathrm{Ne}$, Ar

3571 by $\mathrm{Ne}, \mathrm{Kr}, \mathrm{Xe}$

4059 by $S F$

3208 by $\mathrm{T} 1$

$\mathrm{E}, \mathrm{T}$

3512 by $\mathrm{D}_{2}$

3705 by $\mathrm{He}, \mathrm{Ne}, \mathrm{Ar}$

3874 by $\mathrm{He}, \mathrm{Ne}, \mathrm{Ar}, \mathrm{Kr}, \mathrm{Xe}$

4354 by $\mathrm{He}, \mathrm{Ne}, \mathrm{Ar}, \mathrm{Kr}, \mathrm{Xe}, \mathrm{H}_{2}, \mathrm{D}_{2}$, $\mathrm{O}_{2}, \mathrm{~N}_{2}, \mathrm{CO}_{2}, \mathrm{SF}_{6}, \mathrm{CO}$

4668 by $\mathrm{He}, \mathrm{Ne}, \mathrm{Ar}, \mathrm{Kr}, \mathrm{Xe}$

4651 by $\mathrm{He}, \mathrm{Ne}, \mathrm{Ar}, \mathrm{Kr}, \mathrm{Xe}$
3570 by $\mathrm{Hg}$

3511 by $\mathrm{Kr}$, $\mathrm{Xe}$

4692 by $\mathrm{Kr}, \mathrm{Xe}$

4691 by $\mathrm{Kr}$, $\mathrm{Xe}$

4789 by $\mathrm{Ne}$, Ar

4331 by $\mathrm{T} 1$

4039 by $\mathrm{Xe}$

4040 by $\mathrm{Xe}$

$\mathrm{T}$.

4703 by Ar

3239 by $\mathrm{Ar}, \mathrm{Kr}, \mathrm{Xe}$

3382 by $\mathrm{Ar}, \mathrm{Kr}, \mathrm{Xe}$

4151 by $\mathrm{Ar}, \mathrm{Kr}, \mathrm{Xe}$

3947 by $\mathrm{He}, \mathrm{Kr}, \mathrm{Xe}$

4247 by $\mathrm{He}, \mathrm{Ne}, \mathrm{Ar}, \mathrm{Kr}, \mathrm{Xe}$

4497 by $\mathrm{He}, \mathrm{Ne}, \mathrm{Ar}, \mathrm{Kr}$, Xe

\section{$\operatorname{Tm} I$}

E

4398 by $\mathrm{Ar}$

4128 by $\mathrm{He}$

4539 by $\mathrm{He}$

4645 by $\mathrm{Kr}$

4944 by Xe

\section{U I}

E, T

4241 by $\mathrm{He}$, Xe

\section{$\mathrm{Xe} I$}

E

4990 by $\mathrm{He}$, Ne, Ar 


\section{Mechanism : van der Waals.}

Perturbed element; pertubing element; reference number as in part 3.

3232 by $\mathrm{He}, \mathrm{Ne}, \mathrm{Ar}, \mathrm{Xe}$

5027 by $\mathrm{He}, \mathrm{Ne}, \mathrm{Ar}, \mathrm{Xe}$

3393 by $\mathrm{He}, \mathrm{Xe}$

4122 by $\mathrm{He}, \mathrm{Xe}$

3657 by Xe

4051 by Xe

4145 by $\mathrm{Xe}$

3959 by Xe

E, T

3194 by $\mathrm{He}$

3757 by $\mathrm{He}, \mathrm{Ne}, \mathrm{Ar}, \mathrm{Xe}$

3870 by $\mathrm{Xe}$

T

4946 by $\mathrm{He}$

4853 by $\mathrm{He}, \mathrm{Ne}$

4122 by $\mathrm{He}, \mathrm{Ne}, \mathrm{Ar}, \mathrm{Kr}, \mathrm{Xe}$

4947 by $\mathrm{Ne}$

3327 by $\mathrm{Xe}$

\section{$\mathrm{Yb} I$}

E

5020 by $\mathrm{He}, \mathrm{Ne}, \mathrm{Ar}, \mathrm{Kr}, \mathrm{Xe}, \mathrm{Yb}$

$\mathrm{E}, \mathrm{T}$

5043 by $\mathrm{He}$

4538 by $\mathrm{He}, \mathrm{Ar}, \mathrm{Xe}$ 
3082. THE LINE WIDTH IN PHOTOGRAPHIC SPECTROPHOTOMETRY. II.THE OPTICAL LINE PROFILE. Junkes J., Salpeter E. W., Ric. Spettrosc., Lab. Astrofis. Specola Vaticana 2 No. 7, 255.(Ger.)

\section{0}

3083. SPECTROPHYSICAL PROPERTIES OF THE PLASMA OF A HIGH FREQUENCY LOW POWER DISCHARGE IN ARGON AT ATMOSPHERICAL PRESSURE. Kleinmann I., Cajko J., Spectrochim. Acta, Part B 25, 657.

3084. A STUDY OF THE STARK BROADENING OF ISOLATED ION LINES IN PLASMA. Konjevic N., Grujic P., Cirkovic Lj., Labat J., Fizika (Zagreb) 2, Supp1. 1, 81.

3085. MEASUREMENTS OF THE STARK BROADENING PARAMETERS OF SEVERAL CI I LINES. Konjevic N., Platisa M., Fizika (Zagreb) 2, Suppl. 1, 83.

3086. DETERMINATION OF ELECTRON DENSITY IN PLASMA BY THE NUMBER OF THE EXTREME RESOLVED LINE. Kurochka L. N., Maslennikova L. B., Sol. Phys. 11, 33.

3087. AN INTERFEROMETRIC ANALYSIS OF THE PROFILES OF SPECTRAL LINES EMITTED BY A LOW TEMPERATURE ARC. Mejaski-Tonejc A., Vujnovic V., Fizika (Zagreb) 2, 73.

\section{1}

3088. THEORETICAL CROSS SECTIONS FOR ALIGNMENT DESTROYING COLLISIONS IN THE $2 \mathrm{p}$ LEVEL OF NEON. Carrington C. G., Corney A., J. Phys. B 4, 869.

3089. NARROWING OF LEVEL-CROSSING SIGNALS BY RADIATIVE TRANSFER IN DIFFUSE REFLECTION. I. THEORY. Dodsworth B., Omont A., Phys. Rev. A 3, 1901.

1973

3090. ABSORPTION MULTIPHOTON SPECTROSCOPY WITHOUT DOPPLER EFFECT. Cagnac B., Grynberg G., Biraben F., J. Phys. (Paris) 34, 845.(Fr.) 
3091. CALCULATION OF INELASTIC TRANSITION CROSS SECTIONS ON THE BASIS OF SPECTRAL LINE BROADENING THEORY. Demura A. V., Leneva A. E., Lisitsa V. S., Ordena Lenina Institut Atomnoi Energii im I. V. Kurchatova Report IAE 2269 (1973). (Russ.)

3092. REDISTRIBUTION OF RESONANCE RADIATION. II. THE EFFECT OF MAGNETIC FIELDS. Omont A., Smith E. W., Cooper J., Astrophys. J. 182, 283.

1974

3093. EXCITED MOLECULAR TERMS OF THE ALKALI-RARE GAS ATOM PAIRS. Pascale J., Vandeplanque J., J. Chem. Phys. 60, 2278.

1975

3094. STARK-SHIFT IN THE SPECTRUM OF He II. Murakawa K., Kaku Yogo Kenkyu 34, 51.

3095. ON THE RESONANCE LINE SHAPE MEASUREMENTS IN AXIALLY SYMMETRIC PLASMA SOURCE. Popovic S., Konjevic N., "Proceedings of the Twelfth Int. Conf. on Phenomena in Ionized Gases, Eindhoven, The Netherlands, Part.1, Contributed Papers," 381 (1975).

\section{6}

3096. SOME MEASURED REGULARITIES IN THE STARK BROADENING OF NEUTRAL NITROGEN LINES. Helbig V., Kelleher D. E., Wiese W. L., "Physics of Ionized Gases 1976: Contributions, " 412-415 (Ed. B. Navinsek, J. Stefan Institute, Ljub1 jana, Yugoslavia, 1976).

3097. THE SHAPES OF SPECTRAL LINES EMITTED BY AN INDUCTIVELY COUPLED PLASMA. Human H. G. C., Scott R. H., Spectrochim. Acta, Part B 31, 459.

3098. REGULARITIES IN STARK BROADENING PARAMETERS OF SPECTRAL LINES OF HOMOLOGOUS ALKALINE METALS. Puric J., Labat J., Cirkovic Lj. M., "Physics of Ionized Gases, 1976: Contributions, 420-423, (Ed. B. Navinsek, J. Stefan Institute, Ljubl jana, Yugoslavia 1976).

3099. REGULARITIES IN THE STARK WIDTHS OF ISOLATED LINES. Wiese W. L., Konjevic N., "Physics of Ionized Gases 1976: Contributions," 416-419 (Ed., B. Navinsek, J. Stefan Institute, Ljubl jana, Yugoslavia, 1976). 
3100. DETERMINATION OF ELECTRON DENSITY FROM THE SELF-REVERSED DEUTERIUM D LINE. Aleksandrovich K. V., Berezin I. A., Opt. Spectrosc. (USSR) 43, 13.

3101. INFLUENCE OF COLLISIONS ON THE SATURATION OF A DOPPLER LINE PROFILE. Alekseev V. A., Malyugin A. V., Sov. J. Quantum Electron. 7, 1416.

3102. RELAXATION OF THE ALIGNMENT AND POPULATION OF THE $6{ }^{3} \mathrm{P}_{1}$ LEVEL OF CADMIUM. Alipieva E. A., Boyarskii K. K., Kotlikov E. N., Opt. Spectrosc. (USSR) 43,240 .

3103. THE ANGULAR DEPENDENCE OF PARTIALLY REDISTRIBUTED RESONANCE RADIATION. Ballagh R. J., Cooper J., Astrophys. J. 213, 479.

3104. COMMUTATOR-METHOD FOR COMPUTING SHIFTS OF THE HYPERFINE STRUCTURE OF ATOMIC HYDROGEN ATOM IN A HELIUM MEDIUM. Batygin V. V., Gornyi M. B., Ivanov A. M., Matisov B. G., Sov. Phys.--Tech. Phys. 22, 1397.

3105. QUANTUM CORRECTIONS TO THE SPECTRAL LINE SHIFTS OF HYPERFINE TRANSITIONS. Batygin V. V., Guzhva Yu. G., Matisov B. G., Toptygin I. N., Opt. Spectrosc. (USSR) 43, 479.

3106. QUANTUM THEORY OF SPECTRAL-LINE SHIFTS AND BROADENING FOR HYPERFINE ATOMIC TRANSITIONS IN A BUFFER GAS MEDIUM. Batygin V. V., Guzhva Yu. G., Matisov B. G., Toptygin I. N., Sov. Phys.--JETP 46, 1104.

3107. ALKALI METAL-(INERT) GAS INTERACTIONS. SHAPE OF SPECTRAL LINES AND OPTICAL PUMPING. Bernabeu E., Amare J. C., Alvarez J. M., Pelayo J., Opt. Pura Ap1. 10, 239.(Span.)

3108. THE WIDTH AND SHAPE OF SPECTRAL LINES. Corney A., "Atomic and Laser Spectroscopy" Ch. 8, 229-270 (Clarendon Press, Oxford, England, 1977).

3109. PERTURBATION OF THE ATOMIC SPECTRUM BY A STRONG LIGHT FIELD. Delone N. B., Bul1. Acad. Sci. USSR, Phys. Ser. 41, No. 12, 76.

3110. SPECTRAL LINE WIDTHS IN HIGH FREQUENCY PLASMA DIAGNOSTICS. Djulgerova R., Kapicka V., Folia. Fac. Sci. Nat. Univ. Purkynianae Brun. 18, 7. 
3111. PROFILE OF THE He I $4471 \AA$ LINE AT HIGH ELECTRON DENSITIES IN HELIUM AND HELIUM-NEON PLASMAS. Fleurier C., Chapelle J., Proc. Int. Conf. Phenom. Ioniz. Gases, 13th, 129-130, (Eds. P. Bachmann \& H. Kastelewicz, Buch Export: Leipzig, E. Germany, 1977).

3112. DOPPLER-FREE MULTIPHOTONIC SPECTROSCOPY. Grynberg G., Cagnac B., Rep. Prog. Phys. 40, 791.

3113. ON THE RED SHIFTS OF HYDROGEN SPECTRAL LINES IN DENSE PLASMAS. Halenka J., Musielok J., "Proceedings of the XIIIth Int. Conf. on Phenomena in Ionized Gases - Part I: Contributed Papers" p. 135 (Physical Soc. of the German Democratic Rep., Berlin, 1977).

3114. PERTURBATION OF DEGENERATE ATOMIC LEVELS BY NEUTRAL PARTICLES. IVanov G. K., Opt. Spectrosc. (USSR) 43, 617.

3115. TWO-PHOTON NEAR-RESONANCE LIGHT SCATTERING FROM AN ATOMIC LEVEL. Liran J., Levin L. A., Erez G., Jortner J., Phys. Rev. Lett. 38, 390.

3116. THEORETICAL CALCULATION OF OPTICAL COLLISIONAL CROSS SECTIONS AND $\alpha$ - PARAMETER VALUES FOR TRANSITIONS OF INTEREST IN ATOMIC ABSORPTION SPECTROMETRY. Lovett R. J., Parsons M. L., Appl. Spectrosc. 31, 424.

3117. THE DETERMINATION OF COLLISION DAMPING CONSTANTS. Lwin N., McCartan D. G., Lewis E. L., Astrophys. J. 213, 599.

3118. ${ }^{87} \mathrm{Rb}$ RESONANT FREQUENCY CHANGE DUE TO THE SPECTRAL PROFILE OF THE PUMPING LIGHT. Matsuda I., Shiomi N., Kuramochi N., Fukuyo H., Bull. Res. Lab. Precis. Mach. Electron. 40, 7.

3119. EFFECT OF TEMPERATURE AND CONCENTRATION OF Xe ON THE PARAMETERS OF THE $\mathrm{Cd}^{114} \lambda=326.1 \mathrm{~nm}$ RESONANCE LINE CONTOUR. Misyunas A. A., Norkunas V. K., Stul'pinene N. A., Valuzhis A. D., Sov. Phys.--Collect. 17, No. 2, 76.

3120. TEMPERATURE DEPENDENCE OF THE PARAMETERS OF THE SELF-BROADENED Cd ${ }^{114} \lambda$ $326.1 \mathrm{~nm}$ RESONANCE LINE. Misyunas A. A., Stul'pinene N. A., Valuzhis A. D., Sov. Phys.--Collect. 17, No. 6, 81 .

3121. INFLUENCE OF PERTURBING FOREIGN GASES AND OF TEMPERATURE ON THE SELF-BROADENING OF THALLIUM LINES. Misyunas A. A., Stul'pinene N. A., Sov. Phys.--Collect. 17, 78. 
3122. NON-EQUILIBRIUM EFFECTS IN He-Ar-H ARC PLASMA. Musielok J., Plasma Phys. 17,135 .

3123. LINE BROADENING MEASUREMENT IN HIGH DENSITY PLASMA. II. NEUTRAL HELIUM LINES. Okasaka R., Shimizu M., Fukuda K., J. Phys. Soc. Jpn. 43, 1708.

3124. SPECTROSCOPY OF HIGH DENSITY PLASMAS. Peacock N. J., "Proceedings of the XIIth Int. Conf. on Phenomena in Ionized Gases--Invited Lectures," p. 383 (Physical Soc. of the German Dem. Republic, Berlin, 1977).

3125. TECHNIQUE OF OPTICAL POLARIZATION MEASUREMENTS OF PLASMA LANGMUIR TURBULENCE SPECTRUM. Zhuzhunashvili A. I., Oks E. A., Sov. Phys. JETP 46, 1122 .

\section{8}

3126. SPECTRAL DIAGNOSTICS OF THE PLASMA OF HIGH-CURRENT PULSED DISCHARGES IN DEUTERIUM. Aleksandrovich K. V., Berezin I. A., J. Appl. Spectrosc. (USSR) 28, 146.

3127. RESONANCE BROADENING OF TWO-PHOTON S-S TRANSITIONS. Alekseev V. A., Yatsenko L. P., Sov. Phys.--JETP 48, 1020.

3128. SPECTRAL PROFILE ANALYSIS USING A VOIGT PROFILE ANALYTICAL APPROXIMATION. Alvarez J. M., Bernabeu E., Opt. Pura Ap1. 11, 99.(Span.)

3129. INSTRUMENT CONTOUR OF A NONIDEAL FABRY-PEROT INTERFEROMETER. 3 : INVESTIGATION OF THE SIMULTANEOUS EFFECT OF MANY FACTORS ON THE INSTRUMENT AND OBSERVED CONTOUR. Babaev V. S., Kuchinskii V. V., Opt. Spectrosc. (USSR) 45, 208.

3130. INSTRUMENTAL CONTOUR OF A NONIDEAL FABRY-PEROT INTERFEROMETER. 4. INSTRUMENTAL CONTOUR OF A DEVICE CONTAINING A REAL INTERFEROMETER. BabaeV V. S., Zatsepa L. F., Kuchinskii V. V., Fafurina E. N., Opt. Spectrosc. (USSR) 45, 795 .

3131. LINE SHAPE OF RADIATIVE COLLISIONS IN AN EXTERNAL MAGNETIC FIELD. Bakaev D. S., Vdovin Yu. A., Opt. Spectrosc. (USSR) 44, 380.

3132. VUV ABSORPTION PROFILES OF PRESSURE BROADENED LINES IN DENSE LABORATORY PLASMAS. Baker E. A. M., Burgess D. D., "Physics of Ionized Gases 1978: Contributions," 387-391 (Ed. R. K. Janev, Institute of Physics, Beograd, Yugoslavia, 1978). 
3133. ELECTRON-IMPACT WIDTHS AND SHIFTS OF NEUTRAL HELIUM LINES IN A PLASMA. Bassalo J. M., Cattani M., Phys. Rev. A 18, 2488.

3134. INTERATOMIC POTENTIALS, HYPERFINE SHIFTS, AND DIFFUSION OF RUBIDIUM AND CESIUM ATOMS IN HELIUM. Batygin V. V., Gornyi M. B., Gurevich B. M., Sov. Phys.--Tech. Phys. 23, 613.

3135. HYPERFINE SHIFT AND INTERATOMIC POTENTIALS OF ALKALI AND HYDROGEN ATOMS IN A BUfFER GAS. Batygin V. V., Gornyi M. B., Sov. Phys.--Tech. Phys. 23, 1413.

3136. SOME COMMENTS ON THE LIMB SHIFT OF SOLAR LINES. Beckers J. M., Vegvar P. de, Sol. Phys. 58, 7.

3137. ELECTRON IMPACT WIDTHS OF SOME Ar(II)-U.V.-MULTIPLETS. Behringer K., Thoma P., J. Quant. Spectrosc. Radiat. Transfer 20, 615.

3138. DECONVOLUTION OF SPECTRAL LINES BY FOURIER ANALYSIS. Bennett W. R. Jr., App1. Opt. 17, 3344 .

3139. EFFECTS OF COLLISIONS ON LINEAR AND NON-LINEAR SPECTROSCOPIC LINE SHAPES. Berman P. R., Phys. Rep. 43C, 101.

3140. BROADENING OF THE $2 p^{5} 3 p-2 p^{5} 4 d$ NEON SPECTRAL LINES BY HELIUM. Bielski A., Lisicki E., Nesterov M., Wolnikowski J., Acta Phys. Pol. A 54, 611.

3141. SELF BROADENING OF THE $2 p^{5} 3 p-2 p^{5} 4 d$ SPECTRAL LINES OF NEON. Bielski A. Wolnikowski J., Acta Phys. Pol. A 54, 601.

3142. RELAXATION OF THE ${ }^{4} \mathrm{D}_{3 / 2}$ AND ${ }^{4} \mathrm{D}_{5 / 2}$ LEVELS OF SODIUM ATOM PERTURBED BY NOBLE GASES. Biraben F., Beroff K., Giacobino E., Grynberg G., J. Phys. (Paris), Lett. 39, L108.

3143. ON CALCULATION OF THE MOLECULAR LINE SHAPE IN THE WINGS. Boulet C., Robert D., Galatry L., J. Quant. Spectrosc. Radiat. Transfer 20, 371.

3144. COLLISION BROADENING AND SHIFTS IN THE SPECTRA OF NEUTRAL AND SINGLY IONIZED CALCIUM. Bowman N. J., Lewis E. L., J. Phys. B 11, 1703.

3145. RELATIVE TRANSITION PROBABILITY AND PRESSURE BROADENING PARAMETERS OF COPPER ATOMIC LINES. Boyer D. W., Wurster W. H., Russo A. L., Treanor C. E., Technical Report AFFDL-TR-78-82 (U. S. Air Force, Wright-Patterson Air Force Base, Ohio, 1978). 
3146. COLLISION BROADENING AND SHIFT OF THE SODIUM 3S-4D AND 3S-5S LINES BY He, Ar AND $\mathrm{N}_{2}$. Bruce D. M., Mirza M. Y., Duley W. W., Opt. Commun. 27, 76.

3147. SPECTROSCOPIC EFFECTS IN DENSE AND ULTRA-DENSE PLASMAS. Burgess D. D., "Physics of Ionized Gases, 1978: Invited Lectures and Progress Reports," 501-541 (Ed., R. K. Janev, Institute of Physics, Beograd, Yugoslavia, $1978)$.

3148. SUB-KILOMETER OPTICAL PATH LASER-SPECTROSCOPIC STUDIES OF PRESSURE BROADENED LINES IN $H$ AND He PLASMAS. Burgess D. D., Kolbe G., Playford C. St. Q., "Physics of Ionized Gases 1978: Contributions," 393-396 (Ed. R. K. Janev, Institute of Physics, Beograd, Yugoslavia, 1978).

3149. MEASUREMENT OF INDUCED-EMISSION CROSS SECTION AND LINE BROADENING OF COPPER LASER LINES $4 \mathrm{p}{ }^{2} \mathrm{P}_{3 / 2}-4 \mathrm{~S}^{2} \mathrm{D}_{5 / 2}$ and $4 \mathrm{p}{ }^{2} \mathrm{P}_{1 / 2}-4 \mathrm{~S}{ }^{2} \mathrm{D}_{3 / 2}$. Chen $\mathrm{C}$. J., Phys. Rev. A 18, 2192 .

3150. THE EFFECTS OF ARGON PRESSURE ON THE RESONANCE LINE OF STRONTIUM. Chen $S$. Y., Wang S. Y., Acta Phys. Pol. A 54, 721.

3151. MEASUREMENTS OF THE STARK BROADENING OF IONIZED SILICON LINES FROM A PLASMA. Chiang W. T., Griem H. R., Phys. Rev. A 18, 1169.

3152. OBSERVATIONS OF LINE-CONTINUUM INTERFERENCE EFFECT IN THE WINGS OF ARGON ION LINES. Chiang W. T., Griem H. R., J. Phys. B 11, L761.

3153. COMPENSATING DOPPLER BROADENING WITH LIGHT-SHIFTS. Cohen-Tannoudji C., Hoffbeck F., Reynaud S., Opt. Commun. 27, 71.

3154. COLLISIONAL REDISTRIBUTION Of RADIATION IN THE NON-IMPACT REGION OF SPECTRAL LINES. Cooper J., Ballagh R. J., Smith E. W., Acta Phys. Pol. A $54,729$.

3155. STARK BROADENING OF NITROGEN (I) VACUUM-U.V. LINES USING A WALL-STABILIZED ARC. Cullmann E., Labuhn F., J. Quant. Spectrosc. Radiat. Transfer 20, 205 .

3156. THE PRESSURE BROADENING OF THE HELIUM $2.06 \mu \mathrm{m}\left(2^{1} \mathrm{P}-2^{1} \mathrm{~S}\right)$ LINE. Damaschini R., Malvern A., Verges J., Phys. Lett. A 69, 4. 
3157. EXPERIMENTAL INVESTIGATION OF THE MERCURY $\lambda=5461 \AA$ LINE IN HIGH PRESSURE DISCHARGES AT $50 \mathrm{~Hz}$ : COMPARISON WITH A RADIATION TRANSFER THEORETICAL MODEL. Damelincourt J. J., Karabourniotis D., Karabourniotis M., Scoarnec L., J. Phys. D 11, 2207.

3158. THEORY OF NATURAL LINE SHAPE. Davidovich L., Nussenzveig H. M., Coherence and Quantum Optics IV, 953-974 (Eds., L. Mande1 \& E. Wolf, Plenum Publishing Corp., New York, 1978).

3159. EXPERIMENTAL STUDY OF SOME CHARACTERISTIC PARAMETERS OF He I SPECTRAL LINE PROFILES $\lambda \lambda=4471 \AA$ AND $4922 \AA$ EMITTED IN VARIOUS PLASMA ARCS. Diatta C. S., Czernichowski A., Holys A., Acta Phys. Pol. A 54, 219.

3160. ON THE BEHAVIOR OF HALF-WIDTHS AND SHIFTS OF NEUTRAL LINES IN THE ZERO-TEMPERATURE LIMIT. Dimitrijevic M. S., Grujic P. V., "Physics of Ionized Gases 1978: Contributions," 261-264 (Ed. R. K. Janev, Institute of Physics, Beograd, Yugoslavia, 1978).

3161. ON THE TEMPERATURE DEPENDENCE OF GAUNT FACTORS. Dimitrijevic M. S., Konjevic N., J. Quant. Spectrosc. Radiat. Transfer 20, 223.

3162. INFLUENCE OF THE POLARIZATION POTENTIAL ON THE STARK BROADENING OF NEUTRAL LINES IN THE ADIABATIC LIMIT. Dimitrijevic M. S., Grujic P. V., "Fourth Europhysics Sectional Conference on Atomic and Molecular Physics of Ionized Gases," p. 96 (Essen, Germany, 1978).

3163. STRUCTURE OF THE HELIUM $\lambda=447.15 \mathrm{~nm} \operatorname{LINE}\left(2^{3} \mathrm{P}-4^{3} \mathrm{D},{ }^{3} \mathrm{~F}\right)$ EMITTED AT DIFFERENT PLASMA CONDITIONS. Drawin H. W., Ramette J., "Physics of Ionized Gases 1978: Contributions," 241-244 (Ed. R. K. Janev, Institute of Physics, Beograd, Yugoslavia, 1978).

3164. STRUCTURE OF THE He I $4{ }^{3} \mathrm{D},{ }^{3} \mathrm{~F}-2{ }^{3} \mathrm{P}(\lambda=447.15 \mathrm{~nm}, \lambda=447.0 \mathrm{~nm})$ SPECTRAL LINE EMITTED FROM A LOW-PRESSURE LINEAR DISCHARGE. Drawin $\mathrm{H}$. W. Ramette J., Z. Naturforsch., Teil A 33, 1285.

3165. LASER INDUCED LIGHT SHIFT IN HELIUM: THEORY AND EXPERIMENT. Dubreuil B., Chapelle J., Physica C (Amsterdam) 94, 233.

3166. APPLICATION OF EXTENDED TWO-LEVEL MODEL THEORY TO DOPPLER-, LASER- AND COLLISION-BROADENED BOUND-BOUND MULTIPHOTON ABSORPTION. Eberly J. H., J. Phys. B 11, L611. 
3167. THE BROADENING OF A SPECTRUM LINE BY FINITE SPECTROMETER RESOLUTION. Engleman R. Jr., Los Alamos Scientific Lab. Report LA-7401 (1978).

3168. LINE SHAPES (ABSORPTION COEFFICIENTS) FOR SATELLITES AND INVERSION OF THE DATA TO OBTAIN INTERACTION POTENTIALS. Exton R. J., Snow W. L., J. Quant. Spectrosc. Radiat. Transfer 20, 1.

3169. OBSERVATION OF AN ION EFFECT IN THE PROFILE OF THE $4471 \AA$ LINE OF He I. Fleurier C., Coulaud G., Chapelle J., Phys. Rev. A, 18.

3170. EXCITED-STATE PHOTON-ECHO RELAXATION IN Na VAPOR. Flusberg A., Mossberg T. W., Hartmann S. R., Opt. Commun. 24, 207.

3171. A SIMPLE FORMULA FOR ESTIMATING STARK WIDTHS OF NEUTRAL LINES.. Freudenstein S. A., Cooper J., Astrophys. J. 224, 1079.

3172. BIBLIOGRAPHY ON ATOMIC LINE SHAPES AND SHIFTS. Fuhr J. R., Miller B. J., Martin G. A., "Bibliography on Atomic Line Shapes and Shifts (June 1975 through June 1978)," Nat. Bur. Stand. (U.S.), Spec. Pub1. 366, Supp1. 3 (U.S. Government Printing Office, Washington, D.C., 1978).

3173. FAR-WING LINE BROAdENING. Gallagher A., Acta Phys. Pol. A 54, 761.

3174. DIAGNOSTIC OF DENSE PLASMAS BY INFRARED SCHLIEREN AND ABSORPTION TECHNIQUES. Glasser J., Viladrosa R., Chapelle J., J. Phys. D 11, 1703.

3175. STARK HALFWIDTHS AND SHIFTS OF IONIC SPECTRAL LINES. Gorchakov L. V., Demkin V. P., Sov. Phys. J. 21, 502.

3176. PROBE AND SPECTRAL MEASUREMENTS OF THE PLASMA PARAMETERS OF AN ARC DISCHARGE WITH A HOLLOW CATHODE. Grdlichko D. P., Sakharov V. B., High Temp. (USSR) 16, 597.

3177. STARK BROADENING OF THE HYDROGEN RESONANCE LINE $\mathrm{L}_{\beta}$ IN A DENSE EQUILIBRIUM PLASMA. Grützmacher K., Wende B., Phys. Rev. A 18, 2140.

3178. COMMENT ON COLLISION-PROCESSES INVOLVED IN "TWO-PHOTON NEAR-RESONANCE LIGHT SCATTERING FROM AN ATOMIC LEVEL". Grynberg G., Biraben F., Kolwas M., Cagnac B., Phys. Rev. A 18, 2387. 
3179. PROFILE OF THE Hn $\beta$ RADIO LINES IN A STATIC ION FIELD. Gulyaev S. A., Sov. Astron.--AJ 22, 572 .

3180. MEASUREMENTS OF THE STARK SHIFTS OF SINGLY IONIZED ARGON LINES. Hashimoto S., Orihara S., Proc. Fac. Sci. Tokai Univ. 14, 95.

3181. ON THE VARIATION OF SPECTRAL LINE WIDTHS WITHIN STARK-BROADENED MULTiPlets. Hey J. D., J. Quant. Spectrosc. Radiat. Transfer 20, 403.

3182. STARK BROADENING OF NITROGEN ION LINES FROM STATES OF HIGH ORBITAL ANGULAR MOMENTUM. Hey J. D., Blaha M., J. Quant. Spectrosc. Radiat. Transfer 20, 557 .

3183. WING PROFILE MEASUREMENTS OF THE Na-DOUBLET LINES IN $\mathrm{C}_{2} \mathrm{H}_{2} / \mathrm{O}_{2} / \mathrm{N}_{2}, \mathrm{H}_{2} / \mathrm{O}_{2} / \mathrm{N}_{2}$ AND $\mathrm{H}_{2} / \mathrm{O}_{2} / \mathrm{Ar}$ FLAMES AT 1 ATM. Jongerius $\mathrm{M}$. J., Hollander $\mathrm{T} j$., Alkemade C. Th. J., J. Quant. Spectrosc. Radiat. Transfer 20, 599.

3184. EFFICIENT COMPUTATION OF SPECTRAL LINE SHAPES. Karp A. H., J. Quant. Spectrosc. Radiat. Transfer 20, 379.

3185. CALCULATIONS OF LINE ABSORPTION FOR THE VOIGT PROFILE. Kato I., Iwasaki A., Adachi A., Shimizu T., J. Opt. Soc. Am. 68, 1008.

3186. APPLICATION OF THE MAGNETIC SCANNING TECHNIQUE FOR MEASURING THE BROADENINGS AND SHIFTS OF THE $D_{1}$ RESONANCE LINE OF RUBIDIUM CAUSED BY INERT GASES. Kazantsev S. A., Kaliteevskii N. I., Rish O. M., Opt. Spectrosc. (USSR) 44, 372 .

3187. TWO-PHOTON LIGHT SHIFT AND TWO-PHOTON LAMB DIPS. Keil R., Toschek P. E., Sov. J. Quantum Electron. 8, 949.

3188. STARK PROFILE CALCULATIONS FOR LYMAN SERIES LINES OF ONE-ELECTRON IONS IN DENSE PLASMAS. Kepple P. C., Griem H. R., NRL Memorandum Report, 3634.

3189. HIGH-FREQUENCY STARK EFFECT ON OPTICALLY EXCITED ATOMS OF A PLASMA IN THE STATIC MAGNETIC FIELD. Kim S. H., J. Appl. Phys. 49, 3066.

3190. PROFILE OF THE FAR WINGS OF SELF-BROADENED RESONANCE LINES IN THE FLUORESCENCE SPECTRUM OF OPTICALLY DENSE CESIUM AND RUBIDIUM VAPOR. Klyucharev A. N., Lazarenko A. V., Movre M., Opt. Spectrosc. (USSR) 45, 839. 
3191. CORRECTNESS OF FORMULATION OF THE PROBLEM OF PLASMA DIAGNOSTICS FROM SPECTRAL LINE PROFILES. Kozyrev A. A., Terpugova N. S., Opt. Spectrosc. (USSR) 44, 390.

3192. SHAPE OF ARGON SPECTRAL LINES EMITTED FROM AN ELECTRIC ARC ( $\mathrm{P}=760$ Torr). STUDY AND APPLICATION OF PRESSURE BROADENING. Kretzas D., Thesis, Université P. Sabatier, Toulouse, France (1978).(Fr.)

3193. ANALYSIS OF THE EFFECT OF FOREIGN GASES IN THE FILTERING ACTION OF A 85 Rb CELL. Kuramochi N., Matsuda I., Fukuyo H., J. Opt. Soc. Am. 68, 1087.

3194. A SUITABLE SYSTEM FOR STUDYING THE EFFECT OF VELOCITY-CHANGING COLLISIONS in SATURATED ABSORPTION: Xe He. Le Gouët J. L., J. Phys. B $11,3001$.

3195. COLLISION BROADENING OF THE POTASSIUM RESONANCE LINES BY NOBLE GASES. Lwin N., McCartan D. G., J. Phys. B 11, 3841.

3196. APPLICATION OF THE MODEL MICROFIELD METHOD TO STARK PROFILES OF ALKALI METAL RESONANCE LINES. Mazure A., Nollez G., Z. Naturforsch., Teil A 33, 1575 .

3197. EXPERIMENTAL STUDY .OF THE STARK-SHIFT OF THE SPECTRUM He II. Murakawa K., Bessho S., Kaku Yugo Kenkyu 40, 93.

3198. TWO-DIMENSIONAL SPECTRAL LINE EMISSION RECONSTRUCTION AS A PLASMA DIAGNOSTIC. Myers B. R., Levine M. A., Rev. Sci. Instrum. 49, 610.

3199. OBSERVATION OF NEW SATELLITES IN THE Cs-Ar SYSTEM USING RESONANCE IONIZATION SPECTROSCOPY. Nayfeh M. H., Hurst G. S., Payne M. G., Young J. P., Phys. Rev. Lett. 41, 302.

3200. BROADENING AND SELF-ABSORPTION OF THE RESONANCE LINES OF H-LIKE LIGHT IONS IN LASER-PRODUCED PLASMAS. Nicolosi P., Garifo L., Jannitti E., Malvezzi A. M., Tondello G., Nuovo Cimento B 48, 133.

3201. EFFECTS OF THE RADIATOR MOTION IN THE CLASSICAL AND QUANTUM-MECHANICAL THEORIES OF COLLISIONAL SPECTRAL-LINE BROADENING. Nienhuis G., J. Quant. Spectrosc. Radiat. Transfer 20, 275.

3202. TWO-PHOTON ABSORPTION BY ATOMS PERTURBED BY COLLISIONS. Nienhuis G., Schuller F., Physica C (Amsterdam) 94, 394. 
3203. THE USE OF MULTIPOLE EXPANSIONS IN SPECTRAL LINE-BROADENING THEORY. O'Mara B. J., Gietzel P. C., Mon. Not. R. Astron. Soc. 184, 205.

3204. HOMOGENEOUS SATURATION OF THE $6328 \AA$ NEON LASER TRANSITION DUE TO COLLISIONS IN THE WEAK COLLISION MODEL. Otieno A. V, Opt. Commun. 26, 207.

3205. INVESTIGATION OF NON-THERMAL ELECTRIC FIELD FLUCTUATIONS IN A THETA-DISCHARGE GENERATED HELIUM PLASMA USING THE FORBIDDEN TRANSITIONS $\left(2^{3,1} \mathrm{P}-4^{3,1} \mathrm{~F}\right.$ ) OF NEUTRAL HELIUM. Pal R., Thesis, University of Maryland (1978).

3206. BROADENING AND SHIFT OF HYDROGEN LINES BY PLASMA ELECTRONS. Pargamanik L. E., Ginzburg M. D.; Ukr. Fiz. Zh. 23, 898.(Russ.)

3207. INTERACTION POTENTIALS OF Hg-Ar FROM TEMPERATURE DEPENDENT ABSORPTION SPECTRA. Petzold H. C., Behmenburg W., Z. Naturforsch., Teil A 33, 1461.

3208. SELF-BROADENING OF THE T1 $\lambda=377.6 \mathrm{~nm}$ RESONANCE LINE. Pichler G., Carlsten J. L., J. Phys. B 11, L483.

3209. STARK BROADENING OF Ne II LINES. Platisa M., Dimitrijevic M. S., Konjevic N., Astron. Astrophys. 67, 103.

3210. EXPERIMENTAL STARK WIDTHS OF C II U.V. LINES. Platisa M., Popovic M., Konjevic N., J. Quant. Spectrosc. Radiat. Transfer 20, 477.

3211. STARK BROADENING OF S III AND S IV LINES. Platisa M., Popovic M. V., Dimitrijevic M. S., Konjevic N., "Physics of Ionized Gases 1978: Contributions," 245-248 (Ed. R. K. Janev, Institute of Physics, Beograd, Yugoslavia, 1978).

3212. SOME REGULARITIES WITHIN THE STARK WIDTHS OF RESONANCE LINES OF ALKALI-LIKE HOMOLOGOUS ATOMS AND IONS. Puric J., Dimitrijevic M. S., Lakicévic I. S., Phys. Lett. A 67, 189.

3213. REGULARITIES IN STARK BROADENING PARAMETERS OF RESONANT SPECTRAL LINES FROM He TO Ca. Puric J., Glavonic V., "Physics of Ionized Gases 1978: Contributions," 253-256 (Ed. R. K. Janev, Institute of Physics, Beograd, Yugoslavia, 1978). 
3214. EXPERIMENTAL STUDY OF THE Si II (1) MULTiPlet. Puric J., Lesage A., Knezevic V., "Physics of Ionized Gases 1978: Contributions," 237-240 (Ed. R. K. Janev, Institute of Physics, Beograd, Yugoslavia, 1978).

3215. CALCULATION OF THE COLLISIONAL BROADENING AND SHIFT OF THE HYPERFINE COMPONENTS OF THE D LINES OF RUBIDIUM AND CESIUM DURING COLLISIONS WITH ATOMS OF HEAVY INERT GASES. Rebane V. N., Opt. Spectrosc. (USSR) 44, 376.

3216. BROADENING AND SHIFT OF NEUTRAL ALUMINUM LINES BY van der WAALS-INTERACTION WITH ARGON AND HELIUM ATOMS. Röndigs G., Kusch H. J., Astron. Astrophys. 70, 151.

3217. LOW DENSITY APPROXIMATIONS IN THE ADIABATIC THEORY OF PRESSURE BROADENING. Royer A., Acta Phys. Pol. A 54, 805.

3218. SPECTRUM PROFILES IN THE PRESENCE OF STARK, LORENTZ AND DOPPLER BROADENINGS. Rozsnyai B. F., J. Quant. Spectrosc. Radiat. Transfer 19, 641 .

3219. ON THE ION TEMPERATURE DETERMINATION OF AN INHOMOGENEOUS PLASMA FROM DOPPLER PROFILES. Sato M., J. Phys. D 11, 1739.

3220. ON NUMERICAL METHODS OF CORRECTING AN OBSERVED SPECTRAL LINE PROFILE FOR THE INFLUENCE OF THE INSTRUMENT. Sattarov I., Sov. Astron. 22, 372.

3221. EXPERIMENTAL STUDIES OF STARK BROADENING FOR Hé II 304, 1215 AND $1640 \AA$. Smith C. C., Burgess D. D., J. Phys. B 11, 2087.

3222. ELECTRON DENSITY MEASUREMENTS USING THE STARK-BROADENED LINE WINGS OF HYDROGENIC IONS IN LASER-PRODUCED PLASMAS. Smith C. C., Peacock N. J., J. Phys. B 11, 2749.

3223. ANALYSIS OF THE SHAPES OF SPECTRAL-LINE CONTOURS IN A HIGH-PRESSURE ARC. Solyanikova V. A., Opt. Spectrosc. (USSR) 44, 136.

3224. SPECTRAL LINE BROADENING IN NEON DUE TO THE RESONANCE INTERACTION. Stacey D. N., Thompson R. C., Acta Phys. Pol. A 54, 833.

3225. A METHOD FOR DETERMINING THE ELECTRON CONCENTRATION AND TEMPERATURE IN A He PLASMA DISCHARGE WITH ADDItIONS OF Xe AND $\mathrm{CO}_{2}$. Stotskii G. I., High Temp. (USSR) 16, 1 . 
3226. APPROXIMATE LINE SHAPES FOR HYDROGEN. Sutton K., J. Quant. Spectrosc. Radiat. Transfer 20, 333.

3227. PRESSURE EFFECTS ON SPECTRAL LINES. Szudy J., Acta Phys. Pol. A 54, 261.

3228. INFLUENCE OF TURNING POINTS ON THE SHAPE OF PRESSURE BROADENED SPECTRAL LINES. Szudy J., Acta Phys. Pol. A 54, 841.

3229. STARK PROFILES OF THE WINGS OF THE HYDROGEN LYMAN- $\alpha$ LINE. Szudy J., Bull. Acad. Pol. Sci., Ser. Sci. Math. Astron. Phys. 26, 459.

3230. TWO-PHOTON EXCITATION OF Na ATOMS IN A FLAME BY BROAD-BAND LASER IRRADIATION. Van Dijk C. A., Zeegers P. J. Th., Nienhuis G., Alkemade C. Th. J., J. Quant. Spectrosc. Radiat. Transfer 20, 55.

3231. BROADENING OF SPECTRAL LINES BY ELECTRON SCATTERING. II. PURE ABSORPTION IN THE LINE. Vedmich V. G., Astrophysics (USSR), 13, 277.

3232. PHASE-CHANGING BROADENING OF THE LASER LINE OF Xe I AT $\lambda=3.51 \mu \mathrm{m}$. Vetter R., Marié E., J. Phys. B 11, 2845.

3233. SATELLITE OF SEIJF-BROADENED SPECTRAL LINES OF CESIUM AND RUBIDIUM. Veza D., Pichler G., Movre M., "Physics of Ionized Gases 1978: Contributions," 249-252 (Ed. R. K. Janev, Institute of Physics, Beograd, Yugoslavia, 1978).

3234. POLARIZATION SHIFT EFFECT IN HIGH-DENSITY PLASMAS. Volonté S., J. Phys. D 11,1615 .

3235. DETERMINATION OF THE ELECTRON DENSITY IN A HIGH-PRESSURE Na-Xe DISCHARGE FROM THE PROFILE OF A STARK-BROADENED SPECTRAL LINE. Waszink J. H., Flinsenberg H. J., J. Appl. Phys. 49, 3792.

3236. DETERMINATION OF TEMPERATURE AND PLASMA COMPOSITION IN A HIGH-PRESSURE Cs I-Hg-Ar DischaRgE. Waszink J. H., Greef L. G. M. de, J. Appl. Phys. 49, 5150 .

3237. REGULARITIES IN PLASMA-BROADENED LINE WIDTHS. Wiese W. L., Konjevic N., "Physics of Ionized Gases 1978: Contributions," 257-260 (Ed. R. K. Janev, Institute of Physics, Beograd, Yugoslavia, 1978). 
3238. CALCULATED PRESSURE BROADENING AND SHIFT FOR ALKALI-METAL ATOMS PERTURBED BY RARE GASES: TWO PHOTON S-S TRANSITIONS. Wu C. Y. R., Stwalley W. C., Phys. Rev. A 18, 1066.

3239. LONG-RANGE INTERACTIONS OF THE THALLIUM $7{ }^{2} \mathrm{~S}_{1 / 2}$ STATE AND BROADENING AND SHIFT OF THE THALLIUM VIOLET AND GREEN LINES BY RARE GASES. Wu C. Y. R., Stwalley W. C., Proctor T. R., J. Chem. Phys. 69, 4238.

3240. CALCULATED PRESSURE EFFECTS ON SPECTRAL LINES FOR LONG-RANGE INTERATOMIC POTENTIALS: Rb AND Cs WITH HEAVY RARE GASES. Wu C. Y. R., Stwalley W. C., J. Quant. Spectrosc. Radiat. Transfer 20, 211.

3241. DETERMINATION OF ATOMIC VAPOR PRESSURE BY AN OPTICAL ABSORPTION METHOD USING TWO RESONANCE LINES OF THE ELEMENT INVESTIGATED. Yablochkov E. Yu., Muradov V. G., Opt. Spectrosc. (USSR) 44, 382.

1979

3242. SPECTROSCOPIC INVESTIGATION OF PLASMA TURBULENCE. Al-Shiraida Y. S., Hirose A., Skarsgard H. M., Can. J. Phys. 57, 845.

3243. NEON SPECTRAL LINE BROADENING AS A DIAGNOSTIC FOR COMPRESSED LASERFUSION TARGETS. Auerbach J. M., Bailey D. S., Glaros S. S., Koppel L. N., Pan Y. L., Richards L. M., Slivinsky V. W., Thomson J. J., J. Appl. Phys . 50,5478 .

3244. INTERFEROMETRIC STUDY OF UNRESOLVED COMPONENTS OF SPECTRAL LINES. BabaeV A. S., Babaev V. S., Kuchinskii V. V., Fafurina E. N., Opt. Spectrosc. (USSR). 46, 122 .

3245. EXPERIMENTAL INVESTIGATION OF KRYPTON SPECTRA. Baessler P., Obbarius H. U., Schulz-Gulde E., Physica C (Amsterdam) 96, 147.

3246. THE WIDTH OF THE Na D RESONANCE LINE ( $\lambda 5890 \AA$ ) IN ATMOSPHERES OF HELIUM AND NEON AND ATOMIC HYDROGEN. Baird J. P., Eckart M. J., Sandeman R. J., J. Phys. B 12, 355 .

3247. RESONANCE BROADENING IN NEON AT LOW DENSITIES. Baird P. E. G., Burnett K., Damaschini R., Stacey D. N., Thompson R. C., J. Phys. B 12, L143. 
3248. OBSERVATIONS OF HIGH-DENSITY EFFECTS ON SPECTRAL LINE SHAPES IN A DENSE $\left(\mathrm{n}_{\mathrm{e}}>10^{18} \mathrm{~cm}^{-3}\right)$ Z-PINCH DISCHARGE. Baker E. A. M., Burgess D. D., J. Phys. B 12, 2097.

3249. A LINESHAPE OF THE TRAPPED PARTICLE IN ANHARMONIC POTENTIAL. Baklanov Ye. V., Chebotayev V. P., Titov Ye. A., Appl. Phys. 20, 361.

3250. SPECTROSCOPIC DIAGNOSTICS OF A.D.C. NITROGEN PLASMA JET. Baronnet J. M., Rakowitz J., Coudert J. F., Bourdin E., Fauchais P., Erchov, Pavlov E., J. Phys. (Paris), Colloq. C7, Suppl. 7, 40, 247.

3251. SPECTRAL COMPOSITION OF INDUCED EMISSION FROM A COPPER VAPOR LASER AND ITS TIME EVOLUTION. Batenin V. M., Klimovskii I. I., Morozov A. V., Selezneva L. A., High Temp. (USSR) 17, 406.

3252. NARROWING AND DEFORMATION OF THE HYPERFINE STRUCTURE LINES OF ATOMS IN A MAGNETIC FIELD. Batyghin V. V., Toptyghin I. N., Phys. Lett. A 73, 177.

3253. CALCULATION OF THE COLLISIONAL SHIFTS AND BROADENING OF ALKALI ATOMS IN AN ATMOSPHERE OF LIGHT INERT GASES. Batygin V. V., Gornyi M. B., Matisov B. G., Opt. Spectrosc. (USSR) 46, 572 .

3254. THEORY OF LINE SHAPE FOR NONDEGENERATE OPTICAL TRANSITIONS. Batygin $V$. V., Gornyi M. B., Matisov B. G., Opt. Spectrosc. (USSR) 47, 123.

3255. LINE SHAPE. Behmenburg W., "Progress in Atomic Spectroscopy", Part B, Ch. 27, pp. 1187-1226 (Eds. W. Hanle \& H. Kleinpoppen, Plenum Press, New York, 1979).

3256. DIELECTRONIC SATELLITE SPECTRA FOR HIGHLY CHARGED HELIUM-LIKE IONS - III. CALCULATIONS OF $\mathrm{n}=3$ SOLAR FLARE IRON LINES. Bely-Dubau F., Gabriel A. H., Volonté S., Mon. Not. R. Astron. Soc. 186, 405.

3257. DIELECTRONIC SATELLITE SPECTRA FOR HIGHLY CHARGED HELIUM-LIKE IONS - $V$. EFFECT OF TOTAL SATELLITE CONTRIBUTION ON THE SOLAR FLARE IRON SPECTRA. Bely-Dubau F., Gabriel A. H., Volonté S., Mon. Not. R. Astron. Soc. 189, 801 .

3258. THEORY OF SATURATION SPECTROSCOPY INCLUDING COLLISIONAL EFFECTS. Berman P. R., Liao P. F., Bjorkholm J. E., Phys. Rev. A 20, 2389. 
3259. DETERMINATION OF THE INSTRUMENTAL FUNCTION OF A FABRY-PEROT SPECTROMETER. Bernabeu E., Alvarez J. M., Opt. Pura Ap1. 12, 113.(Span.)

3260. BROADENING EFFECTS OF THE $632.8 \mathrm{~nm}$ Ne I LINE DUE TO A HELIUM-NEON MIXTURE. Bielski A., Darowicki H., Szudy J., Z. Naturforsch., Teil A 34 , 519.

3261. LINE-SHAPES IN DOPPLER-FREE TWO-PHOTON SPECTROSCOPY. THE EFFECT OF FINITE TRANSIT TIME. Biraben F., Bassini M., Cagnac B., J. Phys. (Paris) 40, 445.

3262. RELAXATION OF THE SODIUM ATOM IN THE 4D LEVEL BY COLLISIONS WITH NOBLE GASES. I. EXPERIMENTAL ASPECTS. Biraben F., Beroff K., Grynberg G., Giacobino E., J. Phys. (Paris) 40, 519.

3263. THE SHAPE OF COLLISION BROADENED LINES FROM RESONANCE TO THE FAR WINGS. Birnbaum G., J. Quant. Spectrosc. Radiat. Transfer 21, 597.

3264. DOPPLER-BROADENING MEASUREMENTS OF X-RAY LINES FOR DETERMINATION OF THE ION TEMPERATURE IN TOKAMAK PLASMAS. Bitter M., von Goeler S., Horton R., Goldman M., Hill K. W., Sauthoff N. R., Stodiek W., Phys. Rev. Lett. 42, 304.

3265. THE DETERMINATION OF LASER PLASMA ELECTRON DENSITY BY K SPECTRA OF MULTICHARGED IONS. Boiko V. A., Pikuz S. A., Faenov A. Ya., J. Phys. B 12,1889 .

3266. PRESSURE BROADENED ABSORPTION SPECTRUM OF THE MERCURY $1849 \AA$ LINE BY VARIOUS RARE GASES. DETERMINATION OF THE Hg-Xe INTERACTION POTENTIALS. Bras N., Bousquet C., J. Phys. (Paris) 40, 945.(Fr.)

3267. DETERMINATION OF THE ELECTRON DENSITY IN VARIOUS STAGES OF A SPARK DISCHARGE FROM STARK BROADENING OF SPECTRAL LINES. Brezna E., Acta Fac. Rerum Nat. Univ. Comenianae, Phys. 19, 249.

3268. SUPPRESSION OF DOPPLER BROADENING FOR XUV TRANSITIONS IN DENSE PLASMAS. Burgess D. D., Everett D., Lee R. W., J. Phys. B 12, 2755.

3269. PULSED DYE LASER ABSORPTION SPECTROSCOPY WITH METASTABLE AND EXCITED MERCURY ATOMS. Butaux J., Jeannet J. C., Opt. Commun. 28, 81. 
3270. IMPACT AND QUASISTATIC LIMIT IN THE QUANTUM-PATH THEORY OF PRESSURE BROADENING. Butaux J., Nienhuis G., Schuller F., J. Quant. Spectrosc. Radiat. Transfer 21, 123.

3271. PROFILE OF THE LYMAN- $\alpha$ LINE IN THE PRESENCE OF AN ARGON PLASMA. Chambaud G., Millie Ph., Ridard J., Levy B., J. Phys. B 12, 221.

3272. CONVOLUTION ALGORITHM FOR THE LORENTZ FUNCTION. Clough S. A., Kneizys F. X., Appl. Opt. 18, 2329.

3273. OPTICAL DIAGNOSTICS USING A BARIUM ION BEAM FOR SPATIAL RESOLUTION OF PLASMA PARAMETERS. Cobble J. A., Glowienka J. C., IEEE Trans. Plasma Sci. PS-7, 147.

3274. REDISTRIBUTION OF SCATTERED RADIATION BY COLLISIONS IN THE NONIMPACT REGION OF THE SPECTRAL LINE PROFILE. Cooper J., Astrophys. J. 228, 339.

3275. ON THE CONTRIBUTION OF THE ORIENTATION AND VELOCITY RELAXATION TO THE ATOMIC LINE SHAPE. II. LOW PRESSURE REGION. Czuchaj E., Paul E., Acta Phys. Pol. A 56, 547.

3276. ELECTRON DENSITY MEASUREMENT USING THE STARK PROFILES OF AI XII LINES. Datla R. U., Griem H. R., Phys. Fluids 22, 1415.

3277. LINE WIDTHS AND ENERGY SHIFTS OF SPONTANEOUS EMISSION. Deng C.-H., Acta Phys. Sin. 28, 383. (Chinese)

3278. A MODIFIED ADIABATIC THEORY CALCULATION FOR THE STARK BROADENING OF He I $\left({ }^{1} \mathrm{P}^{\circ}-2^{1} \mathrm{~S}\right)$. Dimitrijevic M. S., Grujic P., J. Phys. (Paris), Colloq. C7, Suppl. 7, 40, 119.

3279. ON THE APPROXIMATE SEMICLASSICAL FORMULA FOR THE ELECTRON-IMPACT WIDTH OF MULTIPLY IONIZED ATOM LINES IN PLASMAS. Dimitrijevic M. S., Konjevic N., J. Phys. (Paris), Colloq. C7, Suppl. 7, 40,815.

3280. QUANTUM MECHANICAL CALCULATIONS OF THE STARK BROADENING OF SOME He I LINES FROM PLASMAS. Dimitrijevic M. S., Grujic P., Koledin D., J. Phys. (Paris), Colloq. C7, Suppl.7, 40, 825.

3281. STARK WIDTHS OF MULTIPLY IONIZED ATOMS OF ASTROPHYSICAL INTEREST. Dimitrijevic M. S., "Proceedings of the 3 rd National Conference of Yugoslav Astronomers," 138-143 (Belgrade, Yugoslavia, 1979). 
3282. APPROXIMATE CLASSICAL TRAJECTORIES AND THE ADIABATIC THEORY OF THE STARK BROADENING OF NEUTRAL-ATOM LINES. Dimitrijevic M. S., Grujic P., Z. Naturforsch., Teil A 34, 1362.

3283. EXPERIMENTAL PROFILES OF THE BALMER LINE $\mathrm{H}_{\beta}$ EMITTED FROM AN AFTERGLOW PLASMA WITHOUT AND WITH A SUPERPOSED MAGNETIC FIELD UP TO 10 TESLA. Drawin H. W., Ramette J., Z. Naturforsch., Teil A 34, 1041.

3284. THE PROFILE OF THE He I $4{ }^{3} \mathrm{D},{ }^{3} \mathrm{~F}-2{ }^{3} \mathrm{P}(\lambda=447.15 \mathrm{~nm} ; \lambda=447.0 \mathrm{~nm})$ SPECTRAL LINE EMITTED FROM A LOW-PRESSURE AFTERGLOW PLASMA SUBMITTED TO A MAGNETIC FIELD OF 10 TESLA. Drawin H. W., Ramette J., Z. Naturforsch., Teil A 34, 1051.

3285. DETERMINATION OF THE PARAMETERS OF A VOIGT PROFILE WITH A NONIDEAL INTERFEROMETER. Dunaev V. V., Kuchinskii V. V., Pavlov S. V., J. Appl. Spectrosc. (USSR) 19, 899.

3286. THE WIDTH OF $\mathrm{H}_{\alpha}$ IN AN ATOMIC HYDROGEN ATMOSPHERE. Eckart M. J., Baldwin K. G. H., J. Phys. B 12, L319.

3287. EXPERIMENTAL STUDY OF BALMER- $\alpha$ STARK BROADENING. Ehrich H., Z. Naturforsch., Teil A 34, 188.

3288. OBSERVATION OF ION DYNAMICS IN THE He I $4026 \AA$ STARK PROFILE. Ehrich H., Helbig V., J. Phys. B 12, 1183.

3289. COMMENTS ON THE SPECTROSCOPIC ANALYSIS OF A HIGH-DENSITY PLASMA. Finken K. H. , J. Appl. Phys. 50, 5518.

3290. SPECTROSCOPIC MEASUREMENT OF THE MAGNETIC FIELD IN A HIGH DENSITY PLASMA. Finken K. H., J. Quant. Spectrosc. Radiat. Transfer 22, 397.

3291. EXPERIMENTAL DETERMINATION OF THE CONSTANTS OF THE BROADENING AND THE DISPLACEMENT OF SPECTRAL LINES FROM THEIR SELF-REVERSAL CONTOURS. Fishman I. S., Semin P. S., Desyatnik G. A., Opt. Spectrosc. (USSR) 47, 245.

3292. EFFECT OF THE ION MOTION AT LOW ELECTRON DENSITIES ON THE PROFILES OF THE LINES $4471 \AA$ AND $4922 \AA$ OF He I. Fleurier C., Coulaud G., Chapelle J., J. Phys. (Paris), Colloq. C7, Suppl. 7, 40, 81. 
3293. FOREIGN-GAS INDUCED RELAXATION OF RYDBERG S AND D STATES IN ATOMIC SODIUM. Flusberg A., Kachru R., Mossberg T., Hartmann S. R., Phys. Rev. A $19,1607$.

3294. STARK BROADENING OF Fe I $5383 \AA$. Freudenstein S., Cooper J., Astron. Astrophys. $71,283$.

3295. OBSERVATIONS OF THE COLLISION-INDUCED DIPOLE TRANSITIONS AND OF A QUADRUPOLE TRANSITION FOR BARIUM IN KRYPTON. Fujimoto T., Ueda K., Fukuda K., J. Quant. Spectrosc. Radiat. Transfer 21, 89.

3296. SPACE AND TIME RESOLVED MEASUREMENTS OF ELECTRON AND ATOMIC EXCITED STATES DENSITIES IN A CO LASER-PRODUCED PLASMA OF HELIUM. Gauthier J. C., Geindre J. P., Grand jouan N., J. Phys. (Paris), Colloq. C7, Suppl. 7, 40,737 .

3297. DOPPLER-FREE TWO-PHOTON OPTOGALVANIC SPECTROSCOPY. Goldsmith J. E. M., Ferguson A. I., Lawler J. E., Schawlow A. L., Opt. Lett, 4, 230.

3298. INCLUSION OF ION DYNAMICS IN THE UNIFIED CLASSICAL PATH THEORY OF STARK BROADENING. Greene R. L., Phys. Rev. A 19, 2002.

3299. BROADENING OF THE LYMAN- $\alpha$ LINE OF HYDROGEN BY LOW-FREQUENCY ELECTRIC FIELDS IN DENSE PLASMAS. Griem H. R., Phys. Rev. A 20, 606.

3300. STARK-PROFILE CALCULATIONS FOR LYMAN-SERIES LINES OF ONE-ELECTRON IONS IN DENSE PLASMAS. Griem H. R., Blaha M., Kepple P. C., Phys. Rev. A 19, 2421.

3301. DOPPLER-FREE MULTI-PHOTON EXCITATION: LIGHT SHIFT AND SATURATION. Gryniberg G., J. Phys. (Paris) 40, 657.

3302. RELAXATION OF THE SODIUM ATOM IN THE 4D LEVEL BY COLLISIONS WITH NOBLE GASES. II. THEORETICAL ASPECTS. Grynberg G., Giacobino E., Biraben F., Beroff K., J. Phys. (Paris) 40, 533.

3303. DEGENERACY OF SPECTRAL SERIES IN HYDROGEN PLASMAS. Gurovich V. Ts., spektorov V. L., Engel'sht V. S., High Temp. (USSR) 17, 929.

3304. NEW RESULTS .CONCERNING THE ANALYSIS OF VOIGT FUNCTIONS. Haubold H. J., John R. W., Astrophys. Space Sci. 65, 477. 
3305. ANALYTICAL DESCRIPTION OF A FABRY-PEROT SPECTROMETER. 5: OPTIMIZATION FOR MINIMUM UNCERTAINTIES IN THE DETERMINATION OF DOPPLER WIDTHS AND SHIFTS. Hernandez G., App1. Opt. 18, 3826; 21, 1528 (1982).

3306. A METHOD OF ESTIMATING THE LEVEL OF COLLECTIVE ELECTRIC FIELD FLUCTUATIONS IN A NONTHERMAL PLASMA WITH A TWO-TEMPERATURE ELECTRON GAS. Himmel G., Sowa L., J. Phys. (Paris), Colloq. C7, Suppl.7, 40, 837.

3307. ABSORPTION PROFILE OF A COLLIMATED ATOMIC BEAM, NON-ORTHOGONAL TO A LASER LIGHT. Hirano I., Arditi M., Bull. Nat. Res. Lab. Metrol., Tokyo, Ser. No $39,16(1979)$.

3308. ON THE DECONVOLUTION OF MEASURED CURVES WITH MEASURED APPARATUS FUNCTIONS AND THE INFORMATION CONTENT OF CURVES. Hühnermann H., Menzel N., Z. Naturforsch., Teil A 34, 399.

3309. AN EFFICIENT METHOD FOR EVALUATION OF. THE COMPLEX PROBABILITY FUNCTION: THE VOIGT FUNCTION AND ITS DERIVATIVES. Humlicek J., J. Quant. Spectrosc. Radiat. Transfer 21, 309.

3310. A SIMPLE FORMULA FOR ATOMIC LINE BROADENING BY NEUTRAL HYDROGEN. Irwin A. W., Mon. Not. R. Astron. Soc. 188, 707.

3311. STUDY OF PERTURBATION OF HYPERFINE COMPONENTS OF THE ${ }^{87}$ Rb $\mathrm{D}_{1}$ LINE BY INERT GASES USING A COMPOUND FABRY-PEROT INTERFEROMETER. I zotova S. L., Kantserov A. I., Frish M. S., Opt. Spectrosc. (USSR) 46, 646.

3312. SPACE-DEPENDENT SHIFT OF SPECTRAL LINES IN LASER-PRODUCED PLASMAS. Jaeglé P., Carillon A., Jamelot G., Wehenkel C., J. Phys. (Paris), Lett 40, L551.

3313. INTENSITY AND SHAPE OF SPECTRAL LINES FROM LASER-PRODUCED PLASMAS. Jamelot G., Jaeglé P., Carillon A., Wehenkel C., J. Phys. (Paris), Colloq. Cl, Suppl. 2, 40, 91 :

3314. TWO PHOTON POLARIZATION SPECTROSCOPY. Kaftandjian V. P., Talin B., Klein L., J. Phys. (Paris) 40, 1037.

3315. EXPERIMENTAL STUDY OF STARK BROADENING OF NITROGEN ION LINES IN A THETA PINCH PLASMA. Kallne E., Jones L. A., Barnard A. J., J. Quant. Spectrosc. Radiat. Transfer 22, 589. 
3316. TEST FOR ION DYNAMIC DEPENDENCE OF PLASMA RED SHIFTS IN NEUTRAL HYDROGEN. Kelleher D. E., Konjevic N., Wiese W. L., Phys. Rev. A 20, 1195.

3317. STARK BROADENING OF $\mathrm{H}_{\beta}$ : WINGS CALCULATION. Kertanguy A. de, Tran Minh N., Feautrier N., J. Phys. B 12, 365.

3318. PLASMA PARAMETERS IN LASER IMPLODED TARGETS FROM SPACE-RESOLVED X-RAY SPECTROSCOPY. Key M. H., Lunney J. G., Ward J. M., Evans R. G., Rumsby P. T., J. Phys. B 12, L213.

3319. ANALYTICAL DETERMINATION OF LINEWIDTHS USING THE FABRY-PEROT SPECTROMETER. Khashan M. A., Physica C (Amsterdam) 98, 93.

3320. DECONVOLUTION OF INSTRUMENTAL RESPONSE FOR ASYMMETRIC SPECTRAL LINES. Kielkopf J. F., J. Opt. Soc. Am. 69, 482.

3321. OBSERVATION OF THE SIMULTANEOUS ADDITIVE EFFECT OF SEVERAL XENON PERTURBERS ON THE Cs 6s-9p DOUBLET. Kielkopf J. F., Allard N. F., Phys. Rev. Lett. 43, 196.

3322. EMISSION FROM A DENSE THERMAL HYDROGEN PLASMA. Kon'kov A. A., High Temp. (USSR) $17,571$.

3323. NONLINEAR ABSORPTION METHOD IN A MAGNETIC FIELD FOR MEASURING HOMOGENEOUS WIDTH AND SHIFTS OF SPECTRAL LINES. Kotlikov E. N., Tokarev V. I., Opt. Spectrosc. (USSR) 47, 13.

3324. ANALYSIS OF Rb OPTICAL PUMPING LIGHT SOURCES. Kuramochi N., Matsuda I., Oura N., Fukuyo H., Jpn. J. App1. Phys. 18, 381.

3325. BLURRING OF LINES AT THE LIMIT OF THE HYDROGEN SERIES. Kurochka L. N., Rybko L. B., Astrophysics (USSR) 15, 93.

3326. SOME REGULARITIES OF STARK WIDTHS OF ALKALI-METAL AND SINGLY IONIZED EARTH ALKALI-METAL RESONANT SPECTRAL LINES. Lakicevic I. S., Puric J., Dimitrijevic M. S., "Proceedings of the 3rd National Conference of Yugoslav Astronomers," 144-149 (Belgrade, Yugoslavia, 1979).

3327. HIGH DENSITY SELF-BROADENING OF THE FIRST XENON AND KRYPTON RESONANCE LINE. Laporte P., Damany H., J. Phys. (Paris) 40, 9. 
3328. HIGH DENSITY SELF-BROADENING OF THE 253,65 nm MERCURY RESONANCE LINE. Laporte P., Damany H., J. Quant. Spectrosc. Radiat. Transfer 22, 447.

3329. LINE BROADENING AND RADIATIVE RECOMBINATION BACKGROUND INTERFERENCES IN INDUCTIVELY COUPLED PLASMA-ATOMIC EMISSION SPECTROSCOPY. Larson G. F., Fassel V. A., Appl. Spectrosc. 33, 592.

3330. DOPPLER-FREE INTERMODULATED OPTOGALVANIC SPECTROSCOPY . Lawler J. E., Ferguson A. I., Goldsmith J. E. M., Jackson D. J., Schawlow A. L., Phys. Rev. Lett. 42, 1046.

3331. SHOCK-TUBE MEASUREMENTS OF THE OSCILLATOR STRENGTHS AND STARK CONSTANTS FOR $s-p$ TRANSITIONS IN ATOMIC XENON. Lazovskaya V. R., Tumakaev G. K., Sov. Phys.--Tech. Phys. 24, 328.

3332. STUDY OF THE PLASMA BROADENING OF SPECTRAL LINES OF HYDROGENIC IONS. Lee R. W., J. Phys. B 12, 1129.

3333. STUDY OF ION DYNAMIC EFFECTS ON LYMAN AND BALMER HYDROGEN LINES. Lee R. W., J. Phys.B 12, 1145.

3334. A MODEL STUDY OF NON-THERMAL EFFECTS IN THE PLASMA BROADENING OF SPECTRAL LINES. Lee R. W., J. Phys. B 12, 1165.

3335. EFFECT OF FINE-STRUCTURE SPLITTING ON THE SHAPE OF THE LYMAN $\alpha$ LINE OF HIGH-Z EMITTERS IN ULTRA DENSE PLASMAS. Lee R. W., Phys. Lett. A 71, 224.

3336. A THEORETICAL STUDY OF THE PLASMA BROADENING OF HELIUM-LIKE TRANSITIONS FOR HIGH-Z EMITTERS. Lee R. W., Bromage G. E., Richards A. G., J. Phys. B 12,3445 .

3337. HIGH RESOLUTION TWO-PHOTON SPECTROSCOPY OF Rb RYDBERG LEVELS. Lee S. A., Helmcke J., Hall J.. L., "Springer Series in Optical Sciences--Vol. 21 Spectroscopy IV," 130-141 (Eds., H. Walther \& K W. Rothe, Springer-Verlag, Berlin, Germany, 1979).

3338. STUDY OF COLLISIONAL REDISTRIBUTION USING TWO-PHOTON ABSORPTION. WITH A NEARLY-RESONANT INTERMEDIATE STATE. Liao P. F., Bjorkholm J. E., Berman P. R., Phys. Rev. A 20, 1489. 
3339. THE ESR SPECTRUM AND LINEWIDTH MEASUREMENTS OF ATOMIC IODINE. Lilenfeld H. V., Richardson R. J., J. Chem. Phys. 70, 3859.

3340. LEAST SQUARES ANALYSIS OF VOIGT-SHAPED LINES. Lin C. L., Shaw J. H., Calvert J. G., J. Quant. Spectrosc. Radiat. Transfer 22, 253.

3341. THE PRESSURE AND DOPPLER LINE BROADENING OF ATOMIC FLUORESCENCE OF THALLIUM IODIDE PERTURBED BY HYDROGEN. Lisicki E., Szudy J., Wolnikowski J., Acta Phys. Pol. A 56, 557.

3342. LINE BROADENING AS LIGHT EMISSION DURING A COLLISION PROCESS. Lisitsa V. S., Acta Phys. Pol. A 55, 87.

3343. XUV SPECTROSCOPIC STUDIES OF A CARBON LASER PRODUCED PLASMA. Malvezzi A. M., Garifo L., Jannitti E., Nicolosi P., Tondello G., J. Phys. B 12, 1437.

3344. DECONVOLUTION OF SPECTRAL LINES: AN IMPROVED METHOD. Mar S., Gigosos M. A., Moreno J. M., Appl. Opt. 18, 2914.

3345. MMM PROFILES OF He I LINES: ION DYNAMICS EFFECT. Mazure A., Goldbach C., Nollez G., Z. Naturforsch., Teil A 34, 773.

3346. COPPER ION LASER: LINE.BROADENING STUDIES. McNeil J. R., Collins G. J., DeHoog F. J., J. Appl. Phys. 50, 6183.

3347. TRANSITION PROBABILITIES AND STARK-BROADENING PARAMETERS OF NEUTRAL AND SINGLY IONIZED LEAD. Miller M. H., Bengtson R. D., Lindsay J. M., Phys. Rev. A 20, 1997.

3348. EXPERIMENTAL TRANSITION PROBABILITIES AND STARK-BROADENING PARAMETERS OF NEUTRAL AND SINGLY IONIZED TIN. Miller M. H., Roig R. A., Bengtson R. D., Phys. Rev. A 20, 499.

3349. TWO-PHOTON OPTICAL FREE INDUCTION DECAY MEASUREMENT BY BROAD-BAND EXCITATION IN UNDIRECTIONAL BEAMS. Mitev V. M., Pavlov. L. I., Stamenov K. V., Phys. Lett. A 72, 209.

3350. DETERMINATION OF THE PLASMA PARAMETERS AND THE SUPRATHERMAL MICROFIELDS IN A CRITICAL VELOCity ROTATing PLASMa. Möbius E., Piel A., Himmel G., Z. Naturforsch., Teil A 34, 405. 
3351. SHAPES OF OPTICAL EMISSION LINES FROM ATOMS EXCITED BY FAST ION IMPACT. II. INITIAL EXPERIMENTAL RESULTS. Morgan F. J., Dugan C. H., Lowe R. P., Can. J. Phys. 57, 1934.

3352. MEASUREMENT OF COLLISION BROADENING OF THE CALCIUM RESONANCE LINE BY LOW RESOLUTION SPECTROSCOPY. Myint H., Hill R. M., Hindmarsh W. R., J. Quant. Spectrosc. Radiat. Transfer 22, 489.

3353. DETERMINATION OF OPTICAL CROSS-SECTIONS FOR SOME Na AND Li LINES WITH A SHOCK TUBE. Nakajima S., Kosasa K., Maruyama Y., Spectrochim. Acta, Part B $34,283$.

3354. REPLY TO "COMMENTS ON THE SPECTROSCOPIC ANALYSIS OF A HIGH-DENSITY PLASMA." Neufeld C. R., J. Appl. Phys. 50, 5520.

3355. FINE STRUCTURE AND SPECTRAL BROADENING OF BALMER LINES IN LASER-PRODUCED PLASMAS. Nicolosi P., Tondello G., Jannitti E., Phys. Rev. A 20, 2574.

3356. NEAR-WING ASYMMETRIES OF THE SELF-BROADENED FIRST Rb AND Cs RESONANCE LINES. Niemax K., Movre M., Pichler G., J. Phys. B 12, 3503.

3357. LINE STRENGTHS IN SPECTRA OF SATURATED NEARLY RESONANT LIGHT SCATTERING FROM COLLISIONALLY PERTURBED ATOMS. Nienhuis G., Schuller F., J. Phys. B 12,3473 .

3358. INFORMATION IN SPECTRA OF COLLISION-BROADENED ABSORPTION LINES. Niple E., Shaw J. H., Appl. Spectrosc. 33, 569.

3359. SUPRATHERMAL FIELD FLUCTUATIONS AND HIGH ENERGY ELECTRONS IN A LOW DENSITY PLASMA: A SPECTROSCOPIC INVESTIGATION. Pal R., Griem H. R., Phys.Fluids 22, 1790 .

3360. LASER-DRIVEN FORBIDDEN TRANSITIONS TO HIGH-L STATES IN He. Panock R., Rosenbluh M., Lax B., Miller T. A., Phys. Rev. Lett. 42, 172.

3361. METHOD FOR DECOMPOSING OBSERVED LINE SHAPES RESULTING FROM MULTIPLE CAUSES; APPLICATION TO PLASMA CHARGE-EXCHANGE NEUTTRAL SPECTRA. Patch R. W. , J. Quant. Spectrosc. Radiat. Transfer 22, 273.

3362. ON THE CONTRIBUTION OF THE ORIENTATION AND VELOCITY RELAXATION TO THE ATOMIC LINE SHAPE. I. MODERATE PRESSURE REgION. Paul E., Acta Phys. Pol. A 55,333 . 
3363. LINE SHAPES FOR LASER-INDUCED COLLISIONS. Payne M. G., Anderson V. E., Turner J. E., Phys. Rev. A 20, 1032.

3364. MODEL-POTENTIAL METHOD FOR THE CALCULATION OF ATOM-RARE-GAS INTERACTIONS: APPLICATION TO THE Na-Ne SYSTEM. Philippe M., Masnou-Seeuws F., Valiron P., J. Phys. B 12, 2493.

3365. THE ROLE OF MOLECULAR LINES IN THE STUDY OF PLASMA SATELLites. Piel A., Pinnekamp F., J. Phys. (Paris), Colloq. C7 40, 813.

3366. THE ROLE OF HYDROGEN MOLECULAR LINES IN THE VICINITY OF $\mathrm{H}_{\beta}$. Piel A., Richter H., Z. Naturforsch., Teil A 34, 516.

3367. SHIFTS OF THE $\mathrm{n}=4$ HYDROGEN AND $3{ }^{3} \mathrm{D}$ HELIUM LEVELS INDUCED BY TEA CO${ }_{2}$ LASER RADIATION. Pignolet P., Bouchoule A., Davy P., Dubreuil B., Wackherr P., J. Phys. (Paris) Lett. 40, L431.

3368. STARK BROADENING OF He I $3965 \AA$. Pilon P. J., Barnard A. J., Can. J. Phys. 57, 1553.

3369. VELOCITY-SELECTIVE OPTICAL PUMPING AND DOPPLER-FREE SPECTROSCOPY. Pinard M., Aminoff C. G., Laloë F., Phys. Rev. A 19, 2366.

3370. THE INFLUENCE OF MOLECULAR TRANSITIONS ON THE SPECTRUM OF THE HELIUM LINE AT $\lambda=447.15 \mathrm{~nm}$ IN A LOW-PRESSURE DISCHARGE. Pinnekamp F., Z. Naturforsch., Teil A 34, 529.

3371. STARK BROADENING OF S III AND S IV LINES. Platisa M., Popovic M., Dimitrijevic M., Konjevic N., J. Quant. Spectrosc. Radiat. Transfer 22, 333 .

3372. BROADENING OF THE $\lambda=589.0 \mathrm{~nm} \mathrm{Na}$ I RESONANCE LINE IN COLLISIONS WITH DIPOLAR MOLECULES. Popov K. G., Ruzov V. P., Salganik Yu. A., Sivkov V. N., Opt. Spectrosc. (USSR) $46,20$.

3373. BROADENING OF THE SODIUM RESONANCE LINE $\lambda-589.0 \mathrm{~nm}$ DUE TO COLLISIONS WITH ATOMS AND MOLECULES. Popov K. G., Ruzov V. P., Vestn. Leningr. Univ. Fiz. Khim. 4, 31.(Ru.)

3374. SHOCK-TUBE STUDIES OF ATOMIC SILICON EMISSION IN THE SPECTRAL RANGE 180 T0 $300 \mathrm{~nm}$. Prakash S. G., Park C., Prog. Astronaut. Aeronaut. 64, 245. 
3375. ACCURACY ATTAINABLE IN DETERMINING THE PARAMETERS OF THE VOIGT CONTOUR OF A SPECTRAL LINE. Preobrazhenskii N. G., Sedelnikov A. I., Opt. Spectrosc. (USSR) 46, 219.

3376. A PARAMETRIC SOLUTION OF THE PROBLEM OF THE "ELIMINATION" OF THE DOPPLER BROADENING OF A SPECTRAL LINE. Preobrazhenskii N. G., Sedel'nikov A. I., J. Appl. Spectrosc. (USSR) 30, 546.

3377. SCHEME FOR EXPANDING A VOIGT PROFILE INTO COMPONENTS. Preobrazhenskii N. G., Sedel'nikov A. I., J. Appl. Spectrosc. (USSR) 30, 697.

3378. BROADENING AND SHIFT OF NEUTRAL CHROMIUM ABSORPTION LINES BY VARIOUS PERTURBING GASES. Pujol G., Weniger S., J. Quant. Spectrosc. Radiat. Transfer 22,145 .

3379. SOME REGULARITIES WITHIN THE STARK WIDTHS AND SHIFTS OF RESONANCE LINES OF NEUTRAL ATOMS FROM He TO Ca. Puric J., Lakicevic I. S., Glavonjic V., J. Phys. (Paris), Colloq. G7, Supp1. 7, 40, 795.

3380. SOME REGULARITIES WITHIN THE STARK WIDTHS AND SHIFTS OF RESONANCE LINES OF SINGLY CHARGED IONS FROM He TO Ca. Puric J., Lakicevic I. S., Glavonjic V., J. Phys. (Paris), Colloq. C7, Supp1.7, 40, 835.

3381. COMPARISON OF COLLISIONAL REDISTRIBUTION AND EMISSION LINE SHAPES. Raymer M. G., Carlsten J. L., Pichler G., J. Phys. B 12, L119.

3382. CALCULATION OF COLLISION BROADENING AND SHIFT OF HYPERFINE COMPONENTS OF HEAD LINES OF THE DIFFUSE SERIES OF GALLIUM, INDIUM, AND THALLIUM ATOMS. Rebane V. N., Opt. Spectrosc. (USSR) 46, 644.

3383. BROADENING AND SHIFT OF HYPERFINE COMPONENTS OF A $j=3 / 2-j_{0}=3 / 2$. SPECTRAL LINE AS THE RESULT OF COLLISIONS WITH NEUTRAL ATOMS. Rebane V. N., Opt. Spectrosc. (USSR) 47, 472 .

3384. EXPERIMENTAL EVIDENCE FOR COMPENSATION OF DOPPLER BROADENING BY LIGHT SHIFTS. Reynaud S., Himbert M., Dupont-Roc J., Stroke H. H., Cohen-Tannoudji C., Phys. Rev. Lett. 42, 756.

3385. SPECTRAL AND MEAN ABSORPTION COEFFICIENTS OF A CARBON PLASMA. Romanov $G$. S., Stepanov K. I., Syrkin M. I., Opt. Spectrosc. (USSR) 47, 476. 
3386. ELECTRON IMPACT BROADENING OF ALUMINUM I-LINES. Röndigs G., Kusch H. J., Astron. Astrophys. 71, 44.

3387. THE STARK WIDTH OF THE Ar I-LINE $3949 \AA$ IN A MEDIUM ELECTRON DENSITY PLASMA. Röndigs G., Kusch H. J., Astron. Astrophys. 75, 182.

3388. CONTINUOUS EMISSION, LOWERING OF THE IONIZATION POTENTIAL AND TOTAL EXCITATION CROSS-SECTIONS OF AN ATMOSPHERIC THERMAL PLASMA. Rosado R. J., Schram D. C., Leclair J., J. Phys. (Paris), Colloq. C7, Suppl. 7, 40, 285 .

3389. PRESSURE AND POWER BROADENINGS OF THE SATURATED ABSORPTION LINES OF IODINE AT $633 \mathrm{~nm}$. Sakurai T., Iwasaki S., Oshida T., Tanaka K., Jpn. J. App1. Phys. 18, 1199.

3390. IONIZATION-INDUCED ATTENUATION OF ATOMIC SPECTRAL LINES IN A PLASMA ELECTRIC MICROFIELD. Savukynas A. J., Ciziunas A. R., Sov. Phys.--Collect: 19, 28 .

3391. EXPERIMENTAL DETERMINATION OF THE CS(7S)-RARE-GAS POTENTIAL ENERGY CURVES AND OF THE 6S-7S COLLISION-INDUCED OSCILLATOR STRENGTHS. Sayer B., Ferray M., Lozingot J., J. Phys. B 12, 227.

3392. ON THE BROADENING OF SPECTRAL LINES BY THE INTERACTION OF PHOTONS WITH A NEW FIELD. Schatzman E., Astron. Astrophys. 74, 12.

3393. PRESSURE SHIFTS OF THE $3.51 \mu \mathrm{m}$ LINE IN XENON. Schwamb D. H., Phys. Lett. A 71,420 .

3394. HYDROGEN STARK BROADENING BY ION IMPACTS ON MOVING EMITTERS. Seidel J., Z. Naturforsch., Teil A 34, 1385.

3395. PRESSURE BROADENING OF RADIO RECOMBINATION LINES FROM MULTIPLE-COMPONENT H II REGIONS. Shaver P: A., Astron. Astrophys. 78, 116.

3396. STARK BROADENING INDUCED BY THE INTENSE ELECTRIC FIELD OF A PULSED RELATIVISTIC MAGNETRON. Shefer R. E., Bekefi G., Phys. Fluids 22, 1584.

3397. ESTABLISHMENT OF SAHA-BOLTZMANN EQUILIBRIUM FOR Ar I LOWER EXCITED ATOMS IN A WALL-CONFINED ARC PLASMA. Shindo H., Imazu S., Jpn. J. Appl. Phys. 18, 2019. 
3398. SPECTRAL LINE BROADENING DUE TO COULOMB INTERACTION. Smirnov G. I., Shapiro D. A., Sov. Phys.--JETP 49, 1054.

3399. EVALUATION OF THE OPTICAL TRANSPARENCY OF A PLASMA. Sokolov A. S., Opt. Spectrosc. (USSR) 47, 563.

3400. EXPERIMENTAL STARK PROFILE DETERMINATION OF SOME PLASMA BROADENED He I AND He II LINES. Soltwisch H., Kusch H. J., Z. Naturforsch., Teil A 34, 300 .

3401. BROADENING AND COLLISIONAL RELAXATION OF THE POTASSIUM $5{ }^{2} \mathrm{P}$ LEVEL PERTURBED BY RARE GASES: COMPARISON OF QUANTAL CALCULATIONS TO SEMICLASSICAL AND EXPERIMENTAL RESULTS. Spielfiedel A., Gilbert D., Roueff E., Rostas F., J. Phys. B 12, 3693.

3402. ON THE ROLE OF ION DYNAMICS IN THE STARK BROADENING OF HYDROGEN LINES. Stamm R., Voslamber D., J. Quant. Spectrosc. Radiat. Transfer 22, 599.

3403. TERM VALUES, PRESSURE BROADENINGS AND SHIFTS IN HIGH RYDBERG LEVELS OF RUBIDIUM. Stoicheff B. P., Weinberger E., "Springer Series in Optical Sciences--Vol. 21 Spectroscopy IV," 264-272 (Eds., H. Walther \& K.W. Rothe, Springer-Verlag, Berlin, Germany, 1979).

3404. DETERMINATION OF ION TEMPERATURE DISTRIBUTIONS FROM DOPPLER BROADENINGS OF IMPURITY LINES IN THE VACUUM UV REGION FOR TOKAMAK DISCHARGES. Sugie T., J. Phys. Soc. Jpn. 46, 250.

3405. EXPERIMENTAL PROFILES OF $6{ }^{2} \mathrm{~S}_{1 / 2}-7{ }^{2} \mathrm{P}_{1 / 2}$ AND $6{ }^{2} \mathrm{~S}_{1 / 2}-7{ }^{2} \mathrm{P}_{3 / 2}$ CESIUM LINES, OBTAINED IN A TWO-PHOTON IONIZATION PROCESS. Toader E. I., Rev. Roum. Phys. 24, 453.

3406. INFLUENCE OF THE BOUNDARY LAYER OF A SHOCK-HEATED PLASMA ON THE STARK PROFILES OF THE AI I RESONANCE LINES. Truong-Bach, Drawin H. W., J. Quant. Spectrosc. Radiat. Transfer 22, 389.

3407. NOMOGRAM FOR THE DETERMINATION OF THE PARAMETERS OF THE VOIGT CONTOUR OF A SPECTRAL LINE. Tskhai N. S., J. Appl. Spectrosc. (USSR) 30, 230.

3408. AC STARK EFFECT ON THE SATURATED ABSORPTION LINE SHAPE IN A PARTIALLY DOPPLER-COMPENSATED SYSTEM. Tsukakoshi M., Shimoda K., Jpn. J. Appl. Phys. 18, 419 . 
3409. MEASUREMENT OF BROADENING PARAMETERS OF NEUTRAL CARBON LINES IN THE VACUUM Ultraviolet. Vadla C., Vujnovic V., Phys. Rev. A. 20, 1573.

3410. BROADENING OF SPECTRAL LINES. Vainshtein L. A., Sobel'man I. I., Yukov E. A., "Excitation of Atoms and Broadening of Spectral Lines," Ch. 7 , 250-319 (Nauka, Glav. Red. Fiz.--Mat. Lit., Moskva, 1979).(Russ.)

3411. THE SHAPE OF SATELLITE LINES IN CLASSICAL BROADENING THEORY INCLUDING DOPPLER EFFECT. Vallee 0., Tran Minh N., Chapelle J., J. Phys. B 12, L9.

3412. THE $3{ }^{2} \mathrm{~S}_{1 / 2}-3^{2} \mathrm{D}_{5 / 2}$ INTERVAL IN ATOMIC HYDROGEN. I. TWO-PHOTON LINE-SHAPE THEORY. Van Baak D. A., Clark B. O., Pipkin F. M., Phys. Rev. A 19,787 .

3413. STUDY OF THE EFFECT OF LIGHT SHIFTS AND BUFFER GAS SHIFTS ON THE HYPERFINE TRANSITION OF ${ }^{87} \mathrm{Rb}$ : INFLUENCE OF THE LONG TERM FREQUENCY STABILITY OF THE RUBIDIUM MASER. Vanier J., Nguyen D. H., Busca G., Tetu M., Can. J. Phys. 57, 1380.

3414. PRESSURE EFFECTS OF He AND Xe ON THE RESONANCE LINE OF STRONTIUM. Wang $S$. Y., Ch'en S. Y., J. Quant. Spectrosc. Radiat. Transfer 22, 87.

3415. SPECTROSCOPIC INVESTIGATION OF AN ARGON PLASMA. Watanabe Y., Hirabayashi N., Trans. Jpn. Soc. Aeronaut. Space Sci. 22, 104.

3416. SHIFT AND BROADENING OF RESOLVED HYDROGEN BALMER- $\alpha$ FINE-STRUCTURE LINES IN HELIUM. Weber E. W., Phys. Rev. A 20, 2278.

3417. ANOMALOUS SHIFTS OF HYDROGEN BALMER- $\alpha$ FINE STRUCTURE LINES IN HELIUM. Weber E. W., Goldsmith J. E. M., Phys. Lett. A 70, 95.

3418. SELF-BROADENING OF DOPPLER-FREE TWO-PHOTON LINES OF Cs. Weber K. H., Niemax K., Opt. Commun. 28, 317.

3419. SELF-BROADENING AND SHIFT OF DOPPLER-FREE TWO-PHOTON LINES OF Rb. Weber K: H. , Niemax K., Opt. Commun. 31, 52 .

3420. PHOTON ESCAPE PROBABILITIES FOR STARK-BROADENED LYMAN SERIES LINES. Weisheit J. C., J. Quant. Spectrosc. Radiat. Transfer 22, 585. 
3421. ON THE RELEVANCE OF MOLECULAR LINES FOR THE MEASUREMENT OF THE HIGH-FREQUENCY STARK EFFECT IN HELIUM. Wiegart N. J., Lins G. A. W., Kunze H. J., J. Phys. B 12, 3495.

3422. SELF-BROADENING OF THE Na 3S-5S and 3S-4D TWO-PHOTON TRANSITIONS. Woerdman J. P., Opt. Commun. 28, 69.

3423. EXPLOSIVE-PUSHER-TYPE LASER COMPRESSION EXPERIMENTS WITH NEON-FILLED MICROBALlOONS. Yaakobi B., Steel D., Thorsos E., Hauer A., Perry B., Skupsky S., Geiger J., Lee C. M., Letzring S., Rizzo J., Mukaiyama T., Lazarus E., Halpern G., Deckman H., Delettrez J., Soures J., McCrory R., Phys. Rev. A 19, 1247.

3424. THEORY OF COLLISIONALLY AIDED RADIATIVE EXCITATION. Yeh S., Berman P. R., Phys. Rev. A 19, 1106.

3425. ABSORPTION CROSS SECTIONS IN THE TAILS OF MAGNESIUM AND BARIUM RESONANCE LINES IN THE PRESENCE OF INERT GASES. Zhuvikin G. V., Penkin N. P., Shabanova L. N., Opt. Spectrosc. (USSR) 46, 642.

\section{0}

3426. REPLY TO COMMENTS ON "SPECTROSCOPIC INVESTIGATION OF PLASMA TURBULENCE." Al-Shiraida Y. S., Hirose A., Skarsgard H. M., Can. J. Phys. 58, 430.

3427. ALKALI RARE-GAS LINE PROFILE IN A SQUARE-WELL POTENTIAL APPROXIMATION: WIDTH, SHIFT, AND ASYMMETRY. Allard N. F., Biraud Y. G., J. Quant. Spectrosc. Radiat. Transfer 23, 253.

3428. ON PATH LENGTHS OF INTEGRATION IN THE COMPUTATION OF THE VOIGT FUNCTION. Andersen T. B., J. Quant. Spectrosc. Radiat. Transfer 24, 341.

3429. SIMULTANEOUS SPECTROSCOPIC DETERMINATION OF SEVERAL INTRINSIC PROFILE PARAMETERS OF A COMPLEX SPECTRAL LINE. Babaev V. S., Zhiglinskii A. G., Izmailov A. M., Kuchinski.i V. V., Fafurina E. N., J. Appl. Spectrosc. (USSR) $32,440$.

3430. AN INTERFEROMETRIC AND SPECTROSCOPIC STUDY ON A HIGH-CURRENT ARGON ARC. Baessler P., Kock M., J. Phys. B 13, 1351. 
3431. ASYMMETRY OF STARK PROFILES OF HYDROGENLIKE LINES CAUSED BY DIFFERENTIATED POPULATION OF ATOMIC STATES. Baryshnikov F. F., Sholin G. V., Opt. Spectrosc. (USSR) 48, 571.

3432. SEMICLASSICAL CONVERGENT CALCULATIONS FOR THE ELECTRON-IMPACT BROADENING AND SHIFT OF SOME LINES OF NEUTRAL HELIUM IN A HOT PLASMA. Bassalo J. M., Cattani M., Walder V. S., Phys. Rev. A 22, 1194.

3433. EFFECT OF A MAGNETIC FIELD ON LORENTZ COLLISIONS IN ACETYLENE-AIR FLAMES. Bassyouni A. H., Issa M. A. A., Hafez A. F., J. Quant. Spectrosc. Radiat. Transfer 23, 503 .

3434. SHIFT AND ADIABATIC BROADENING OF THE HYPERFINE-TRANSITION LINES OF ATOMS ON THE WALL OF A GAS CELL. Batygin V. V., Ostryakov V. M., Sokolov I. M., Sov. Phys.--Tech. Phys. 25, 969.

3435. HYPERFINE SHIFTS, BROADENING AND TEMPERATURE COEFFICIENTS OF THE FREQUENCY: THEORY AND ANALYSIS OF EXPERIMENTAL DATA. Batygin Vit. V., Batygin V1. V., Gornyi M. B., Gurevich B. M., Sov. Phys.--Tech Phys. 25, 31.

3436. APPLICATION OF LASER SPECTROSCOPY TO COLLISIONAL STUDIES. Berman P. R., Ann. Phys. (Paris) 5, 199.

3437. SHIFT AND BROADENING OF HYPERFINE COMPONENTS OF THE FIRST DOUBLET OF CESIUM PERTURBED BY FOREIGN GASES. Bernabeu E., Alvarez J. M., Phys. Rev. A 22,2690 .

3438. LOW PRESSURE BROADENING AND SHIFT OF THE $540.06 \mathrm{~nm}$ LINE OF NEON. Bielski A., Dokurno W., Szudy J., Wolnikowski J., Physica C (Amsterdam) 101, 113.

3439. HARTREE-FOCK CALCULATIONS OF THE INTERACTION POTENTIAL PARAMETERS FOR NOBLE-GAS ATOMS. Bielski A., Wasilewski J., Z. Naturforsch., Teil A 35 , 1112 .

3440. THE SELF-BROADENED PROFILE OF THE MERCURY $1849 \AA$ LINE. DETERMINATION OF Hg-Hg INTERACTION POTENTIALS. Bousquet C., Bras N., J. Phys. (Paris) 41, 19. (Fr.)

3441. H $\alpha$ AND $\mathrm{H} \beta$ SPECTRAL PROFILES FROM NEUTRAL BEAMS AND PLASMAS IN HIGH MAGNETIC FIELDS. Breton C., De Michelis C., Finkenthal M., Mattioli M., J. Phys. B 13, 1703. 
3442. INERT-GAS COLLISIONAL BROADENING AND SHIFTS OF Rb RYDBERG STATES. Brillet W. -Ü L., Gallagher A., Phys. Rev. A 22, 1012.

3443. OBSERVATIONS OF THE COLLISION-INDUCED He I $2{ }^{3} \mathrm{P}-3{ }^{1}$ D INTERCOMBINATION LINE IN A LABORATORY PLASMA. Burgess D. D., Playford C. St. Q., J. Phys. B 13, L245.

3444. COLLISIONAL REDISTRIBUTION OF RADIATION. III. THE EQUATION OF MOTION FOR THE CORRELATION FUNCTION AND THE SCATTERED SPECTRUM. Burnett K., Cooper J., Phys. Rev. A 22, 2044.

3445. - COLLISIONAL REDISTRIBUTION OF RADIATION. II. THE EFFECTS OF DEGENERACY ON THE EQUATIONS OF MOTION FOR THE DENSITY MATRIX. Burnett K., Cooper J., Phys. Rev. A 22, 2027.

3446. COLLISIONAL REDISTRIBUTION OF RADIATION. I. THE DENSITY MATRIX. Burnett K., Cooper J., Ballagh R. J., Smith E. W., Phys. Rev. A 22, 2005.

3447. SPECTRAL PROFILE ANALYSIS AT THE ATOMIC SPECTROSCOPY LABORATORY (DRP Paris): PURPOSES AND METHODS. Butaux J., Ann. Phys. (Paris) 5, 301.(Fr.)

3448. PRESSURE BROADENING STUDIES ON THE $3{ }^{3} \mathrm{D}_{1}-2{ }^{3} \mathrm{P}_{0}$ HELIUM LINE BY SATURATED-ABSORPTION TECHNIQUES. Cahuzac Ph., Damaschini R., Opt. Commun. $32,251$.

3449. BROADENING OF THE SODIUM D LINES BY RARE GASES. Chatham R. H., Gallagher A., Lewis E. L., J. Phys. B 13, L7.

3450. ON THE SHIFTS OF SELF-REVERSED MAXIMA OF THE SODIUM RESONANCE RADIATION. Chien Y. M., J. Appl. Phys. 51, 2965.

3451. EFFECTS OF BLACKBODY RADIATION ON HIGHLY EXCITED ATOMS. Cooke W. E., Gallagher T. F., Phys. Rev. A 21, 588.

3452. ZEEMAN DEGENERACY EFFECTS IN COLLISIONAL INTENSE-FIELD RESONANCE FLUORESCENCE. Cooper J., Ballagh R. J., Burnett K., Phys. Rev. A 22, 535.

3453. STUDY OF COLLISION-INDUCED ABSORPTION IN DIPOLE ELECTRONIC TRANSITIONS OF ALKALI-RARE GAS ATOM PAIRS. Czuchaj E., Z. Phys. A 298, 237. 
3454. EXPERIMENTAL EVIDENCE FOR LIGHT-SHIFT INDUCED ZERO-FIELD LEVEL CROSSING ("OPTICAL HANLE EFFECT"). Delsart C., Keller J. C., Kaftand jian V. P., Opt. Commun. 32, 406.

3455. QUENCHING OF HIGH RYDBERG STATES OF SODIUM IN STRONG $1.06 \mu \mathrm{m}$ LASER FIELDS. Dewhurst R. J., Pert G. J., Scott A. M., J. Phys. B 13, 2759.

3456. THE DISAPPEARANCE AND BROADENING OF RYDBERG STATES OF SODIUM IN A STRONG LASER FIELD. Dewhurst R. J., Pert G. J., Scott A. M., "Laser Advances and Applications," 99-102 (J. Wiley \& Sons, Chichester, Great Britain, 1980).

3457. ELECTRON DENSITIES IN LASER-TRIGGERED HYDROGEN SPARKS. Dhali S. K., Williams P. F., Crumley R. J., Gundersen M. A., IEEE Trans. Plasma Sci. PS-8, 164 .

3458. EXCHANGE AND POLARIZATION EFFECTS IN THE ELEMENTARY EXCITATION SPECTRUM OF A HYDROGEN ATOM IMMERSED IN A HOT PLASMA. Dharma-wardana M. W. C., Grimaldi F., Lecourt A., Pellissier J. L., Phys. Rev. A 21, 379.

3459. PRESSURE BROADENING AND PRESSURE SHIFT OF THE CADMIUM INTERCOMBINATION LINE AT $\lambda=3261 \AA$. Dietz K. J., Dabkiewicz P., Kluge H. J, Kühl T., Schuessler H. A., J. Phys. B 13, 2749.

3460. STARK WIDTHS OF DOUBLY- AND TRIPLY-IONIZED ATOM LINES. Dimitrijevic M. S., Konjevic N., J. Quant. Spectrosc. Radiat. Transfer 24, 451.

3461. BROADENING OF IONIC LINES OBSERVED ALONG THE AXIS OF A HIGH-CURRENT DISCHARGE OF AN ARGON LASER. Donin V. I., Opt. Spectrosc. (USSR) 48, 583.

3462. LINE EMISSION FROM HOT, DENSE, ALUMINUM PLASMAS. Duston D., Davis J., Phys. Rev. A 21, 1664.

3463. EXPER IMENTAL INVESTIGATION OF PLASMA-BROADENED HYDROGEN BALMER LINES AT LOW ELECTRON DENSITIES. Ehrich H., Kelleher D. E., Phys. Rev. A 21, 319.

3464. MOLECULAR-DYNAMICS SIMULATION OF PRESSURE BROADENING OF SODIUM RESONANCE LINE BY ARGON. Erickson G. J., Sando K. M., Phys. Rev. A 22, 1500.

3465. SPECTROSCOPIC INVESTIGATION OF THE $\operatorname{Cs}\left({ }^{7} \mathrm{~S}_{1 / 2}\right.$ AND $\left.{ }^{5} \mathrm{D}_{5 / 2 ; \mathrm{m}=1 / 2}\right)$ - He INTERACTION. Ferray M., Visticot J. P., Lozingot J., Sayer B., J. Phys. B $13,2571$. 
3466. KINETIC TEMPERATURES AND ELECTRON DENSITIES IN THE PLASMA OF A SIDE VIEW GRIMM-TYPE GLOW DISCHARGE. Ferreira N. P., Human H. G. C., Butler L. R. P., Spectrochim. Acta, Part B 35, 287.

3467. INVESTIGATION OF THE H $\alpha$ LINE IN DENSE PLASMAS. Finken K. H., Buchwald R., Bertschinger G., Kunze H. J. , Phys. Rev. A 21, 200.

3468. ION-MOTION EFFECT IN THE STARK PROFILES OF H $\alpha$ AND H $\beta$. Fleurier C., Coulaud G., Ranson P., Chapelle J., Phys. Rev. A 21, 851.

3469. STUDY OF ION DYNAMICS EFFECTS AT LOW ELECTRON DENSITIES ON THE LINES He I 447. I AND $492.2 \mathrm{~nm}$. Fleurier C., Coulaud G., Chapelle J., Physica C (Amsterdam) 100, 127.

3470. DETERMINATION OF ATOMIC PROFILES BY FOURIER ANALYSIS AND DECONVOLUTION OF PEROT-FABRY INTERFEROGRAMS. COMPARISON OF TWO METHODS OF INTERFEROGRAM PROCESSING. Fourcade N., J. Opt. (Paris) 11, 57 (1980).(Fr.)

3471. CONVOLUTION OF A DOPPLER LINE BY A GAUSSIAN INSTRUMENT FUNCTION. Fridovich B., Devi V. M., Das P. P., J. Mol. Spectrosc. 81, 269.

3472. STUDY OF TURBULENT HEATING EFFECTS IN THE HIGH BETA TOKAMAK TORUS II. Georgiou G. E., Marshall T. C., Weber P. G., Phys. Fluids 23, 2085.

3473. INTERPRETATION OF MEASURED SPECTRAL LINE SHAPES USING A SQUARE-WELL POTENTIAL: THE ABSORPTION LINES OF CESIUM BROADENED BY RARE GASES. Gilbert D. E., Allard N. F., Ch'en S. Y., J. Quant. Spectrosc. Radiat. Transfer 23, 201 .

3474. SECOND DERIVATIVE TUNABLE DIODE LASER SPECTROMETRY FOR LINE PROFILE DETERMINATION. II. EXPERIMENTAL RESULTS. Grieble D. L., Olson M. L., Sun J. N.-P., Griffiths P. R., Appl. Spectrosc. 34, 56.

3475. FOREIGN GAS BROADENING OF THE $5{ }^{1} \mathrm{P}_{1}$ LEVEL OF Cd. Hanle W., Scharmann A., Wirz P., Phys. Lett. A 77, 240.

3476. SPECTROSCOPIC MEASUREMENT OF HIGH-DENSITY $\mathrm{CO}_{2}$-LASER-DRIVEN IMPLOSION. Hauer A., Mitchell K. B., van Hulsteyn D. B., Tan T. H., Linnebur E. J., Mueller M. M., Kepple P. C., Griem H. R., Phys. Rev. Lett. 45, 1495. 
3477. STARK BROADENING OF ISOLATED LINES EMITTED BY SINGLY-IONIZED TIN. Hey $\mathrm{J}$. D., Breger P., J. Quant. Spectrosc. Radiat. Transfer 23, 311.

3478. CALCULATED STARK WIDTHS OF ISOLATED S III AND S IV LINES. Hey J. D., Breger P., J. Quant. Spectrosc. Radiat. Transfer 24, 427.

3479. CALCULATED STARK WIDTHS OF OXYGEN ION LINES. Hey J. D., Breger P., J. Quant. Spectrosc. Radiat. Transfer 24, 349.

3480. MEASUREMENT OF THE SPECTRUM OF ELECTRIC-FIELD FLUCTUATIONS IN A PLASMA BY LASER-FLUORESCENCE SPECTROSCOPY. Hildebrandt J., Kunze H. J., Phys. Rev. Lett. 45,183 .

3481. SHIFT OF X-RAY LINES IN LASER-COMPRESSED PLASMAS FOR DIRECT MEASUREMENT OF THE DENSITY. Hora H., Atomkernenergie 35, 64.(Ger.)

3482. LEAST SQUARES METHOD FOR ANALYZING BROADENED X-RAY LINE SHAPES. Howe11 R. H., Matthews D. L., J. Quant. Spectrosc. Radiat. Transfer 23, 513.

3483. CALCULATION OF THE HYPERFINE SPLITTING AND THE SHIFT OF A SPECTRAL LINE IN THE THEORY OF ATOMIC FLUORESCENCE ANALYSIS. II'in G. G., Razumov V. A., Fishman I. S., J. Appl. Spectrosc. (USSR) 31, 1203.

3484. AN INTERPRETATION OF THE BLUE SATELLITE TO RESONANCE LINES OF HELIUM-LIKE IONS OF THIRD SEQUENCE ELEMENTS IN LASER-PRODUCED PLASMAS. Irons F. E., Aust. J. Phys. 33, 25.

3485. AN INTERPRETATION OF ANOMALOUS INTENSITY RATIOS WITHIN THE HYDROGEN-LIKE L- $\alpha$ DOUBLET IN OPTICALLY THICK LASER-PRODUCED PLASMAS. Irons F. E., Aust. J. Phys. 33, 283.

3486. DETERMINATION OF THE SHIFTS AND BROADENING OF THE HYPERFINE COMPONENTS OF THE ${ }^{87} \mathrm{Rb} \mathrm{D}_{2}$ LINE DUE TO COLLISIONS WITH ATOMS OF THE INERT GASES He AND Ar. Izotova S. L., Kantserov A. I., Frish M. S., Opt. Spectrosc. (USSR) 49, 546 .

3487. DOPPLER-FREE SPECTROSCOPY OF THE $5882 \AA$ LINE OF ${ }^{20} \mathrm{Ne}$ I. Jabr S. N., Bennett W. R. Jr., Phys. Rev. A 21, 1518.

3488. THE BROADENING OF SPECTRAL LINES BY AUTOIONIZATION, RADIATIVE TRANSITIONS, AND COLLISIONS. Jacobs V. L., Davis J., Naval Research Laboratory Report 4365 (1980). 
3489. DOPPLER-FREE TWO-PHOTON LASER SPECTROSCOPY OF BARIUM I: HYPERFINE SPLITTING AND ISOTOPE SHIFT OF HIGH LYING LEVELS. Jitschin W., Meisel G., Z. Phys. A 295, 37.

3490. NOBLE-GAS-INDUCED BROADENING OF TRANSITIONS TO RYDBERG S AND D STATES IN ATOMIC SODIUM. Kachru R., Mossberg T. W., Hartmann S. R., Phys. Rev. A 21,1124 .

3491. NOBLE-GAS BROADENING OF THE SODIUM D LINES MEASURED BY PHOTON ECHOES. Kachru R., Mossberg T. W., Hartmann S. R., J. Phys. B 13, L363.

3492. SHAPE OF THE Hg $2537 \AA$ RESONANCE LINE IN THE PRESENCE OF Hg $\left(6{ }^{3} \mathrm{P}_{1}\right)$ -Hg $\left(6^{1} \mathrm{~S}_{0}\right)$ InTERACTIONS. Kacprzyk M., Acta Phys. Pol. A 57, 773.

3493. STARK BROADENING OF He II $4686 \AA$ : A DIRECT COMPARISON OF PREDICTIONS FROM TWO THEORIES WITH EXPERIMENT. Källne E., Jones L. A., J. Phys. B 13, L437.

3494. DYNAMICS OF STRONTIUM LINE SHAPES DURING A PULSED DISCHARGE IN A MIXTURE WITH HELIUM. Karabut E. K., Kravchenko V. F., Mikhalevskii V. S., Opt. Spectrosc. (USSR) 48, 386.

3495. ANALYSIS OF THE TEMPERATURE DEPENDENCE OF ${ }^{87}$ Rb LAMP PROFILES. Karamochi N., Matsuda I., Oura N., Fukuyo H., J. Opt. Soc. Am. 70, 1504.

3496. USE OF GENERALIZED POPULATION RATIOS TO OBTAIN Fe XV LINE INTENSITIES AND LINEWIDTHS AT HIGH ELECTRON DENSITIES. Kastner S. O., Bhatia A. K., Phys. Rev. A 22, 560 .

3497. CALCULATIONS OF LINE ABSORPTION FOR THE VOIGT PROFILE AND SOME SPECIFIC LINES OF HELIUM. Kato I., Yonehara A., J. Opt. Soc. Am. 70, 866.

3498. RELATION BETWEEN THE BROADENING OF RYDBERG LEVELS AND RESONANCES IN THE SCATTERING OF SLOW ELECTRONS BY ATOMS. Kaulakis B. P., Opt. Spectrosc. (USSR) 48, 574.

3499. MEASUREMENT OF THE WIDTH, SHIFT AND ASYMMETRY OF THE SODIUM D LINES BROADENED BY NOBLE GASES. Kielkopf J. F., J. Phys. B 13, 3813.

3500. DETERMINATION OF Cs(np)-Xe INTERACTIONS FROM SPECTRAL LINE PROFILE MEASUREMENTS. Kielkopf J. F., Allard N. F., J. Phys. B 13, 709. 
3501. X-RAY SPECTROSCOPIC DIAGNOSIS OF LASER-PRODUCED PLASMAS, WITH EMPHASIS ON LINE BROADENING. Kilkenny J. D., Lee R. W., Key M. H., Lunney J. G., Phys. Rev. A 22, 2746.

3502. SPECTROSCOPIC MEASUREMENT OF THE ELECTRON PLASMA DENSITY OF THE "HOT SPOT" IN A LOW-INDUCTANCE VACUUM SPARK. Kononov E. Ya., Koshelev K. N., Safronova U. I., Sidel'nikov Yu. V., Churilov S. S., JETP Lett. 31, 679.

3503. COLLISIONAL DEPOLARIZATION AND REDISTRIBUTION OF LASER RADIATION IN NEAR RESONANCE WITH A ${ }^{2} \mathrm{P}_{3 / 2}-{ }^{2} \mathrm{~S}_{1 / 2}$ TRANSITION. Kroop V., Behmenburg W., Z . Phys. A 294, 299.

3504. PERTURBATION THEORY FOR MICROFIELD DISTRIBUTION IN A NONIDEAL PLASMA. Kurilenkov Yu. K., Filinov V. S., High Temp. (USSR) 18, 345.

3505. STARK SHIFT BY INHOMOGENEOUS STRONG E FIELD. Lambert D., Opt. Commun. 34, 209.

3506. VAN DER WAALS INTERACTION IN TERMS OF THE $\mathrm{Hg} 6{ }^{1} \mathrm{~S}_{0}-\mathrm{Hg} 6{ }^{1} \mathrm{P}_{1}$ POTENTIAL. Leboucher E., Nguyen Hoe, J. Phys. (Paris), Lett. 41, L57.(Fr.)

3507. THE EFFECTS OF DIFFERENT ION SPECIES ON THE SHAPE OF THE HYDROGENIC $\mathrm{n}=4$ TO $\mathrm{n}=1$ PROFILES OF HIGH Z EMITTERS IN ULTRA DENSE PLASMAS. Le $\mathrm{R}$. W., Freeman A. J., J. Quant. Spectrosc. Radiat. Transfer 24, 43.

3508. COLLISIONAL RELAXATION OF ATOMIC EXCITED STATES, LINE BROADENING AND INTERATOMIC INTERACTIONS. Lewis E. L., Phys. Rep. 58, 1.

3509. EFFECTS OF VELOCITY-CHANGING COLLISIONS ON TWO-PHOTON AND STEPWISE-ABSORPTION SPECTROSCOPIC LINE SHAPES. Liao P. F., Bjorkholm J. E., Berman P. R., Phys. Rev A 21, 1927.

3510. SHIFT OF THE T1 I $535.0 \mathrm{~nm}$ LINE BY HYDROGEN. Lisicki E., Z. Naturforsch., Teil A 35, 773 .

3511. COLLISION BROADENING AND SHIFT OF THE $535.0 \mathrm{~nm}$ T1 LINE ACCOMPANYING THE PHOTODISSOCIATION OF THALLIUM IODIDE PERTURBED BY NOBLE GASES Part I: EFFECTS DUE TO Kr AND Xe. Lisicki E., Bielski A., Szudy J., Z. Naturforsch., Teil A 35, 1249. 
3512. EFFECTS OF DEUTERIUM PRESSURE ON THE WIDTH AND SHIFT OF ATOMIC FLUORESCENCE OF THALLIUM IODIDE. Lisicki E., Szudy J., Wolnikowski J., Acta Phys.Pol. A 58, 105.

3513. APPARATUS FUNCTION OF A SPHERICAL INTERFEROMETER. List E., Chaika M. P., Opt. Spectrosc. (USSR) 49, 597.

3514. SYMMETRIZED LIOUVILLE BASIS FOR INDISTINGUISHABLE PARTICLES. APPLICATION TO SPECTRAL LINEWIDTH. Liu W. K., J. Chem. Phys. 72, 4869.

3515. DETERMINATION OF THE TRUE TOTAL LINE INTENSITY AND THE TRUE HALFWIDTH OF THE LORENTZ COMPONENT FOR THE CLASS OF VOIGT PROFILES FROM GRAPHICAL ANALYSIS OF SPECTRUM. Lokner V., Movre M., Fizika (Zagreb) 12, 61.

3516. ATOMIC SPECTRAL OVERLAPS: A MATHEMATICAL MODEL AND ITS USE FOR STUDYING LINE SHAPE PARAMETERS. Lovett R. J., Parsons M. L., Spectrochim. Acta, Part B 35, 615.

3517. SELF-BROADENING IN SINGLET SPECTRAL LINES OF HELIUM. Malvern A. R., Pinder A. C., Stacey D. N., Thompson R. C., Proc. R. Soc. London, Ser. A $371,259$.

3518. THERMODYNAMICAL MEANING OF THE LINE SHIFTS INDUCED BY A FOREIGN GAS. Mayer G., Phys. Lett. A 79, 65.

3519. EXPERIMENTAL RATES OF COLLIDING TRANSITIONS BETWEEN EXCITED LEVELS OF HELIUM ATOMS. Mazing M. A, Slemzin V. A., Shevel'ko A. P., Tr. Fiz. Inst. im. P. N. Lebedeva, Akad. Nauk SSSR 119, 169.(Russ.)

3520. MODEL MICROFIELD METHOD. RECENT APPLICATIONS OF STARK BROADENING OF NEUTRAL LINES. Mazure A., Goldbach Cl., Nollez G., Ann. Phys. (Paris) 5, 219. (Fr.)

3521. EXPERIMENTAL TRANSITION PROBABILITIES AND STARK BROADENING FOR SINGLY-IONIZED BISMUTH. Miller M. H., Bengtson R. D., J. Quant. Spectrosc. Radiat. Transfer 23, 411.

3522. STARK BROADENING TRENDS IN HOMOLOGOUS IONS. Miller M. H., Lesage A., Puric J., Astrophys. J. 239, 410. 
3523. LINE SHAPE OF OPTICAL SATELLITES IN A MAGNETIZED TURBULENT PLASMA. Mizuta Y., J. Phys. Soc. Jpn. 48, 1691.

3524. OBSERVATION OF COLLISIONAL VELOCITY CHANGES ASSOCIATED WITH ATOMS IN A SUPERPOSITION OF DISSIMILAR ELECTRONIC STATES. Mossberg T. W., Kachru R., Hartmann S. R., Phys. Rev. Lett. 44, 73.

3525. NOBLE-GAS - INDUCED COLLISIONAL BROADENING OF THE ${ }^{3} \mathrm{P}_{1 / 2}-{ }^{3} \mathrm{P}_{3 / 2}$ TRANSITION OF SODIUM MEASURED BY THE TRILEVEL-ECHO TECHNIQUE. Mossberg T. W., Whittaker E., Kachru R., Hartmann S. R., Phys. Rev. A 22, 1962.

3526. RESONANCE INTERACTION AND SELF-BROADENING OF ALKALI RESONANCE LINES II. QUASI-STATIC WING PROFIles. Movre M., Pichler G., J. Phys. B 13, 697.

3527. BROADENING OF ATOMIC AND IONIC LINES EMITTER BY PLASMAS. Nguyen Hoe, Caby M., Grumberg J., Coulaud G., J. Phys. (Paris), Colloq. C3, Suppl. 4, 41, 203. (Fr.)

3528. BROADENING OF HYDROGENIC X RAYS EMITTED BY A LASER-PRODUCED PLASMA. Nguyen Hoe, Grumberg J., Caby M., Leboucher E., Coulaud G., Ann. Phys. (Paris) 5, 227.(Fr.)

3529. INVESTIGATIONS ON THREE-BODY Cs-NOBLE-GAS INTERACTION AND SECONDARY SATELLITES. Niemax K., J. Phys. B 13, 1791.

3530. COLLISIONAL BROADENING OF RESONANCE FLUORESCENCE WITH EXCITATION BY INTENSE RADIATION OF FINITE BANDWIDTH. Nienhuis G., J. Phys. B 13, 2217.

3531. SATURATED TWO-PHOTON ABSORPTION BY ATOMS IN A PERTURBER GAS. Nienhuis G.. Physica C (Amsterdam) 101, 259.

3532. COLLISIONAL BROADENING OF SATURATED RESONANCE FLUORESCENCE SPECTRA BY TWO-STATE ATOMS IRRADIATED BY MONOCHROMATIC LIGHT. Nienhuis G., Schuller F., J. Phys. B 13, 2205.

3533. A NEW NONLINEAR LEAST SQUARE ALGORITHM FOR VOIGT SPECTRAL LINES. NOII R. J., Pires A., Appl. Spectrosc. 34, 351.

3534. EXPERIMENTAL ION CONTRIBUTION TO THE STARK BROADENING OF NEUTRAL-NITROGEN SPECTRAL LINES IN THE VACUUM UV. Nubbemeyer H., Phys. Rev. A 22, 1034. 
3535. COLLISIONAL BROADENING OF SPECTRAL LINES IN LABORATORY AND SOLAR SPECTRA I. THE 6162, 6122, $6102 \AA$ MULTIPLET OF NEUTRAL CALCIUM. O'Neil1 J. A., Smith G., Astron. Astrophys. 81, 100.

3536. COLLISIONAL BROADENING OF SPECTRAL LINES IN LABORATORY AND SOLAR SPECTRA II.LOW EXCITATION LINES OF NEUTRAL IRON. O'Neill J. A., Smith G., Astron. Astrophys. 81, 108.

3537. DETERMINATION OF THE PARAMETERS OF AN ABSORPTION SPECTRAL LINE SUBJECT TO PRESSURE EFFECTS. Occelli R., Bachet G., Moynault J. M., J. Phys. (Paris) Lett. 41, L527.(Fr.)

3538. STARK PROFILE MEASUREMENT OF THE He II $4686 \AA$ LINE IN A HIGH DENSITY PLASMA. Oda T., Kiriyama S. I., J. Phys. Soc. Jpn 49, 385.

3539. SECOND DERIVATIVE TUNABLE DIODE LASER SPECTROMETRY FOR LINE PROFILE DETERMINATION I. THEORY. Olson M. L., Grieble D. L., Griffiths P. R., App1. Spectrosc. 34, 50 .

3540. A THEORETICAL AND EXPERIMENTAL APPROACH TO LASER SATURATION BROADENING IN FLAMES. Omenetto N., Bower J., Bradshaw J., Van Dijk C. A., Winefordner J. D., J. Quant. Spectrosc. Radiat. Transfer 24, 147; 25, 189 (1981).

3541. EFFECTS OF INTENSE MAGNETIC AND MOTIONAL STARK FIELDS ON STATE MIXING AND TRANSITION LINE SHAPES. Panock R., Rosenbluh M., Lax B., Miller T. A., Phys. Rev. A 22, 1041.

3542. THE EVALUATION AND CHARACTERIZATION OF VOIGT LINESHAPE. Parthasarathi V., Ganapathy S., McDowell C. A., J. Mol. Struct. 64, 29.

3543. STARK BROADENING OF SPECTRAL LINES OF ATOMS IN THE FIELD OF MULTIMODE LASER RADIATION. Perel'man N. F., Sov. Phys.--JETP 52, 395.

3544. X-RAY LINE RADIATION FROM A CYLINDRICAL ALUMINUM PLASMA. Perez J. D., Payne G. L., Phys. Rev. A 21, 968.

3545. OBSERVATION OF UNIDIRECTIONAL AMPLIFIED SPONTANEOUS EMISSION INDUCED BY VELOCITY-DEPENDENT LIGHT SHIFTS. Petite G., Johnson B. C., Lange W. K. H., Salour M. M., Phys. Rev. Lett. 45, 1242; 45, 1659 (1980). 
3546. DETERMINATION OF COLLISIONAL LINEWIDTHS AND SHIFTS BY A CONVOLUTION METHOD. Pickett H. M., Appl. Opt. 19, 2745.

3547. EFFECTS OF VELOCITY AVERAGING ON THE SHAPES OF ABSORPTION LINES. Pickett H. M., J. Chem. Phys. 73, 6090 .

3548. COMMENTS ON "SPECTROSCOPIC INVESTIGATION OF PLASMA TURBULENCE." Piel A., Pinnekamp F., Can. J. Phys. 58, 429.

3549. PLASMA SHIFTS OF HYDROGENIC-ION LINES. Pittman T. L., Voigt P., Kelleher D. E., Phys. Rev. Lett. 45, 723.

3550. DOPPLER-FREE NONLINEAR PROCESSES IN STRONG OPTICAL FIELDS. Popov A. K., Shalaev V. M., Opt. Spectrosc. (USSR) 49, 336.

3551. COLLISION BROADENING OF THE SODIUM D LINE ( $\lambda=589.6 \mathrm{~nm}$ ). Popov K. G., Ruzov V. P., Opt. Spectrosc. (USSR) $48,372$.

3552. STATISTICAL ANALYSIS OF THE PROBLEM OF DETERMINING THE PARAMETERS FOR THE PROFILES OF PRESSURE BROADENED SPECTRAL LINES. Preobrazhenskii N. G., Sedel'nikov A. I., Opt. Spectrosc. (USSR) 49, 5.

3553. STARK WIDTH AND SHIFT DEPENDENCE ON THE IONIZATION POTENTIAL. Puric J., Lakicevic I. S., Glavonjic V., Phys. Lett. A 76, 128.

3554. COLLISION ANISOTROPY AND IMPACT CONTOUR OF SPECTRAL LINES. Rautian S. G., Rudavets A. G., Shalagin A. M., Sov. Phys.--JETP 51, 274.

3555. A NEW CALCULATION FOR LINE BROADENING OF LYMAN- $\alpha$ IN PLASMAS. Reibold R., Phys. Lett. A 75, 363 .

3556. EMISSION LINE SHAPES FROM A ROTATING RING RADIATOR. Rogoff G. L., J. Opt. Soc. Am. 70, 567 .

3557. SHIFT, WIDTH, AND ASYMMETRY OF PRESSURE-BROADENED SPECTRAL LINES AT INTERMEDIATE DENSITIES. Royer A., Phys. Rev. A 22, 1625.

3558. EFFECTS OF ELECTRIC FIELDS ON DOUBLY EXCITED AUTOIONIZING RYDBERG STATES OF BARIUM. Safinya K. A., Delpech J. F., Gallagher T. F., Phys. Rev. A 22,1062 . 
3559. EXPERIMENTAL INVESTIGATION OF THE Cs $\left({ }^{5} \mathrm{D}_{5 / 2, \mathrm{~m}=1 / 2}\right)$ - RARE-GAS INTERACTION: POTENTIAL CURVES AND OSCILLATOR STRENGTH OF THE DIPOLE-INDUCED TRANSITIONS. Sayer B., Ferray M., Visticot J. P., Lozingot J., J. Phys. B 13,177 .

3560. FAR WINGS OF THE CESIUM FORBIDDEN LINES IN THE PRESENCE OF RARE GASES: INTERACTION POTENTIALS AND OSCILLATOR STRENGTHS OF THE COLLISION INDUCED TRANSITIONS. Sayer B., Ferray M., Visticot J. P., Lozingot J., Ann. Phys. (Paris) 5, 291.(Fr.)

3561. SPECTRAL NARROWING AND SATURATION-INDUCED REBROADENING IN $3.51 \mu \mathrm{m}$ XENON LASER AMPLIFIERS. Schwamb D. H., Smith S. R., Phys. Rev. A 21, 896.

3562. HYDROGEN STARK BROADENING BY DIFFERENT KINDS OF MODEL MICROFIELDS. Seidel J., Z. Naturforsch., Teil A 35, 679.

3563. OBSERVATION OF ANOMALOUSLY BROAD GAUSSIAN He II $4686 \AA$ SPECTRAL LINES IN TORMAC. Shaw R. S., Coonrod J., Greenwald M., Levine M. A., Myers B. R., Vella M. C., Plasma Phys. 22, 843.

3564. AN EXPERIMENTAL INVESTIGATION OF PARTIAL LTE FOR LOWER EXCITED LEVELS OF Ar I IN A WALL-CONFINED, ARGON ARC PLASMA. Shindo H., Imazu S., J. Quant. Spectrosc. Radiat. Transfer 23, 605.

3565. X-RAY LINE SHIFT AS A HIGH-DENSITY DIAGNOSTIC FOR LASER-IMPLODED PLASMAS. Skupsky S., Phys. Rev. A 21, 1316.

3566. NOTE ON THE PAPER BY T.ANDERSEN ENTITLED "THE DIFFERENTIAL EQUATIONS OF THE VOIGT FUnCTIONS." Squire W., J. Quant. Spectrosc. Radiat. Transfer 23, 531 .

3567. INVESTIGATION OF THE RED LASER TRANSITION IN NEON BY MODE-CROSSING AND ZERO-FIELD LEVEL-CROSSING. Stahlberg B., Weckström K., Phys. Scr. 22, 483.

3568. SPECIFIC LINE-BROADENING OF THE IRON RESONANCE-LINE 3859,91 $\AA$ BY COLLISIONS WITH ARGON ATOMS AT HIGH TEMPERATURES. Steinwandel J., Joos V. E., Hauser M., Dietz Th., Z. Naturforsch., Teil A 35, 828.(Ger.)

3569. FREQUENCY SHIFTS, LINE BROADENINGS, AND PHASE-INTERFERENCE EFFECTS IN $\mathrm{Rb}^{* *}+\mathrm{Rb}$ COLLISIONS, MEASURED BY DOPPLER-FREE TWO-PHOTON SPECTROSCOPY. Stoicheff B. P., Weinberger E., Phys. Rev. Lett. 44, 733. 
3570. LINE BROADENING AND RADIATIVE TRANSPORT IN HIGH-PRESSURE MERCURY DISCHARGES WITH Na I AND T1 I AS ADDITIVES. Stormberg H. P., J. App1. Phys. 51, 1963.

3571. MERCURY AND THALLIUM LINE SHAPES PERTURBED BY NOBLE GASES. Stulpinene N., Sov. Phys.--Collect. 20, No. 3, 54.

3572. QUASI-MOLECULAR TREATMENT OF PRESSURE BROADENING OF SPECTRAL LINES BY NEUTRAL PERTURBERS. Szudy J., Ann. Phys. (Paris) 5, 255.

3573. AN INVESTIGATION OF THE POTENTIAL OF OPTICALLY THICK LINE PROFILES FOR DETERMINING LASER-PRODUCED PLASMA PARAMETERS. Tallents G. J., J. Phys. B 13,3057 .

3574. OBSERVATION OF DYNAMIC CORRELATIONS IN COLLISIONAL REDISTRIBUTION AND DEPOLARIZATION OF LIGHT. Thomann P., Burnett K., Cooper J., Phys. Rev. Lett. 45, 1325.

3575. DETERMINATION OF WIDTHS OF ATOMIC LEVELS FROM SPECTRA OF WEAK WAVE ABSORPTION BY ATOMS SITUATED IN A STRONG MONOCHROMATIC FIELD. Toptygina G. I., Filatov P. P., Fradkin E. E., Opt. Spectrosc. (USSR) 49.

3576. SHORT-RANGE POTENTIALS IN QUANTAL AND SEMI-CLASSICAL GALCULATIONS FOR THE Ly $\alpha$ LINE. Tran Minh N., Feautrier N., Edmonds A. R., J. Quant. Spectrosc. Radiat. Transfer 23, 377.

3577. A COMPARISON OF FAST CODES FOR THE EVALUATION OF THE VOIGT PROFILE FUnCTION. Twitty J. T., Rarig P. L., Thompson R. E., J. Quant. Spectrosc. Radiat. Transfer 24, 529.

3578. COLLISION BROADENING OF PRINCIPAL SERIES LINES OF BARIUM IN THE PRESENCE OF KRYPTON. Ueda K., Fujimoto T., Fukuda K., J. Phys. Soc. Jpn 49, 2089.

3579. SODIUM RESONANCES IN FLUORESCENCE FROM WIDE-RANGE LASER SCAN IN $\mathrm{H}_{2}-\mathrm{O}_{2}$-Ar FLAME. Van Dijk C. A., Alkemade G. Th. J., J. Quant. Spectrosc. Radiat. Transfer 23, 445 .

3580. ON THE DETERMINATION OF DAMPING CONSTANTS FOR Fe I LINES IN THE SOLAR PHOTOSPHERE. van Rensbergen W., Deridder G., Sol. Phys. 67, 5. 
3581. BROADENING OF SPECTRAL LINES BY ELECTRON SCATTERING III. EMISSION LINES. Vedmich V. G., Astrophysics (USSR) 16, 91.

3582. LINE SHAPES IN LASER SPECTROSCOPY. Vetter R., Ann. Phys. (Paris) 5, $187 .(\mathrm{Fr}$.

3583. THE SHAPE OF THE INNER-WING SATELLITES OF SELF-BROADENED FIRST RESONANCE LINES OF CAESIUM AND RUBIDIUM. Veza D., Movre M., Pichler G., J. Phys. B 13, 3605 .

3584. A TRIPLET SATELLITE BAND IN THE VERY FAR BLUE WING OF THE SELF-BROADENED SODIUM D LINES. Veza D., Rukavina J., Movre M., Vujnovic V., Pichler G., Opt. Commun. 34, 77 .

3585. RARE GAS COLLISIONAL PERTURBATION OF THE $\left(6{ }^{3} \mathrm{D}_{1}, 6{ }^{1} \mathrm{D}_{2}\right)$ LEVELS OF MERCURY: A THEORETICAL ESTIMATE. Vienne-Casalta D., Margerie J., Gay J. C., J. Phys. (Paris) 41, 503.

3586. DETERMINATION OF NONISOTHERMAL-PLASMA PARAMETERS USING THE PROFILES OF SELF-REVERSED SPECTRAL LINES. Volkova L. M., Devyatov A. M., Kidravov F. Kh., Opt. Spectrosc. (USSR) 49, 122.

3587. THE ION DYNAMIC PROBLEM IN THE STARK BROADENING FIELD. Voslamber D., Ann. Phys. (Paris) 5, 207.(Fr.)

3588. OBSERVATION OF NON-LORENTZIAN SPECTRAL LINE SHAPES IN Na-NOBLE-GAS SYSTEMS. Walkup R. E., Spielfiedel A., Pritchard D. E., Phys. Rev. Lett. $45,986$.

3589. $6{ }^{1} \mathrm{~S}_{0}-6{ }^{3} \mathrm{P}_{0}$ TRANSITION IN ${ }^{199} \mathrm{Hg}$ : DETERMINATION OF THE A COEFFICIENT AND SELF-PRESSURE BROADENING. Wexler B. L., Wilcomb B. E., Djeu N., J. Opt. Soc. Am. 70, 863 .

3590. Na $3{ }^{2} \mathrm{P}-3^{2} \mathrm{D}$ LINE BROADENING BY Ne, Ar, AND Xe. Wildman D. W., Schumann L. W., Gallagher A. C., J. Quant. Spectrosc. Radiat. Transfer 24, 19.

3591. STARK EFFECT OF Ar I LINES. Windholz L., Phys. Scr. 21, 67.

3592. SYMMETRIC LASER COMPRESSION OF ARGON-FILLED GLASS SHELLS TO DENSITIES OF 4-6 g/cm ${ }^{3}$. Yaakobi B., Skupsky S., McCrory R. L., Hooper C. F., Deckman H., Bourke P., Soures J. M., Phys. Rev. Lett. 44, 1072. 
3593. SPECTRAL LINE SHIFTS PRODUCED BY ELECTRON COLLISIONS IN He II PLASMA. Yamamoto K., J. Phys. Soc. Jpn. 49, 730.

3594. QUANTUM SCATTERING THEORY OF THE COMPLEX LEVEL SHIFT OF SPECTRAL LINES IN PLASMAS. Yamamoto K., Narumi H., Prog. Theor. Phys. 64, 436.

3595. DETERMINATION OF THE RELAXATION CONSTANT OF THE $3 s_{2}-3 p_{4}$ TRANSITION IN NEON BY INVESTIGATION OF THE ABSORPTION LINE WINGS. Zhuk V. P., Petrukhin E. A., Savushkin A. F., Sov. J. Quantum Electron. 10, 1441.

\section{1}

3596. OPTICAL PUMPING OF THE HYPERFINE STRUCTURE OF ATOMIC SILVER IN THE GROUND STATE. Aleksandrov E. B., Prilipko V. K., Opt. Spectrosc. (USSR) 51, 121.

3597. THE INFLUENCE OF INTERMEDIATE IONIC STATES ON SPECTRAL-LINE BROADENING. Andreev E. A., Mnatsakanyan A. Kh., Sov. Phys.--Dok1. 26, 508.

3598. STARK BROADENING OF THE NEUTRAL HELIUM LINE 3965 A.. Araujo J. M. R., Bassalo J. M., Cattani M., Walder V. S., Rev. Bras. Fis. 11, 877.

3599. DETERMINATION OF THE RELAXATION CHARACTERISTICS OF THE OPTICALLY FORBIDDEN $3 \mathrm{p}_{4}-3 \mathrm{p}_{2}$ TRANSITION IN NEON. Bakaev D. S., Vdovin Yu. A., Opt. Spectrosc. (USSR) 50, 462.

3600. LINE SHAPES FOR COLLISION BROADENING UNDER ATOMIC-BEAM EXCITATION. Baklanov E. V., Belyaev M. V., Opt. Spectrosc. (USSR) 50, 474.

3601. BROADENING OF SPECTRAL LINES DUE TO OPTICAL TRANSITIONS OF AN ATOM IN A THREE-DIMENSIONAL OSCILLATOR WELL. Baklanov E. V., Titov E. A., Sov. Phys. - JETP 53, 907.

3602. QUANTUM THEORY OF STARK BROADENING OF THE LINES OF HYDROGENLIKE IONS. Baryshenkov F. F., Lisitsa V. S., Sov. Phys.--JETP 53, 471.

3603. STARK PROFILE AND WIDTHS OF THE He I $5016 \AA$ LINE IN A PLASMA. Bassalo J. M., Cattani M., Walder V. S., Rev. Bras. Fis. 11, 881.

3604. SPECTRAL LINE BROADENING AND SHIFT BY COLLISIONS IN AN AIR-ACETYLENE FLAME. Bassyouni A. H., J. Quant. Spectrosc. Radiat. Transfer $26,451$. 
3605. CALCULATIONS OF SOME LINE PROFILES IN ICP-AES ASSUMING A VAN DER WAALS PotentiAl. Batal A., Mermet J. M., Spectrochim. Acta, Part B 36, 993.

3606. FAR WING DEPOLARIZATION OF COLLISION-INDUCED FLUORESCENCE. Behmenburg W., Kroop V., J. Phys. B 14, 427.

3607. ANALYSIS OF COLLISION-BROADENED AND OVERLAPPED SPECTRAL LINES TO OBTAIN INDIVIDUAL LINE PARAMETERS. BelBruno J. J., Zughul M. B., Gelfand J., Rabitz H., J. Mol. Spectrosc. 87, 560 .

3608. MEASUREMENT OF THE CONSTANTS FOR THE BROADENING AND SHIFT OF THE $\mathrm{D}_{2}$ LINE OF RUBIDIUM (780.0 nm) BY INERT GASES. Belov V. N., Opt. Spectrosc. (USSR) $51,209$.

3609. APPLICATION OF THE MAGNETIC-SCANNING METHOD TO THE MEASUREMENT OF THE BROADENING AND SHIFT CONSTANTS OF THE RUBIDIUM $\mathrm{D}_{2} \operatorname{LINE}(780.0 \mathrm{~nm})$ BY FOREIGN GASES. Belov V. N., Opt. Spectrosc. (USSR) 51, 22.

3610. POSSIBILITY OF MEASURING THE COLLISIONAL CONSTANTS OF THE BROADENING AND DISPLACEMENT OF RESONANCE SPECTRAL LINES BY FOREIGN GAS PRESSURE SCANNING. Belov V. N., Chaika M. P., Opt. Spectrosc. (USSR) 50, 334.

3611. REGENT DEVELOPMENTS IN LINE SHAPE THEORY. Ben-Reuven A., "Spectra1 Line Shapes," 867-884 (Ed. B. Wende, Walter de Gruyter \& Co., New York, 1981).

3612. EXPERIMENTAL STARK PROFILES OF He II 3203 AND He II 4686. Bernard J. E., Curzon F. L., Barnard A. J., "Spectral Line Shapes," 153-164 (Ed. B. Wende, Walter de Gruyter \& Co., New York, 1981).

3613. BUFFER GAS PRESSURE SHIFT IN THE $\mathrm{m}_{\mathrm{F}}=0-\mathrm{m}_{\mathrm{F}}=0$ GROUND STATE HYPERFINE LINE IN Cs. Beverini N., Strumia F., Rovera G., Opt. Commun. 37, 394.

3614. TWO-PHOTON LIGHT SHIFT. Bialas J., Firth W. J., Toschek P. E., Opt. Commun. 36,317 .

3615. LOW PRESSURE SHIFT OF THE $2 p^{5} 3 p-2 p^{5} 4 d$ SPECTRAL LINES OF NEON PERTURBED BY NEON AND HELIUM. Bielski A., Bobkowski R., Dokurno W., Szudy J., Acta Phys. Pol. A 59, 107.

3616. LOW PRESSURE BROADENING AND SHIFT OF THE $2 p^{5} 3 p-2 p^{5} 6 s$ NEON SPECTRAL LINES. Bielski A., Bryl K., Dokurno W., Lisicki E., Z. Phys. A 302, 1. 
3617. A DIGITAL FABRY-PEROT SPECTROMETER FOR THE USE IN STUDIES OF PRESSURE BROADENING AND SHIFT OF SPECTRAL LINES. Bielski A., Dokurno W., Lisicki E., Opt. Appl. 11, 151 .

3618. UNRESOLVED DIELECTRONIC SATELLITES OF THE RESONANCE LINE OF HELIUMLIKE IRON ( Fe XXV). Bitter M., von Goeler S., Hill K. W., Horton R., Johnson D., Roney W., Sauthoff N., Silver E., Stodiek W., Phys. Rev. Lett. 47, 921.

3619. SELF-ABSORPTION OF X-RAY SPECTRAL LINES IN AN EXPANDING LASER PLASMA. Boiko V. A., Vinogradov A. V., Ilyukhin A. A., Katulin V. A., Maiorov S. A., Nosach V. Yu., Peregudov G. V., Petrov. A. L., Pikuz S. A., Skobelev I. Yu., Faenov A. Ya., Chirkov V. A., Shilov K. A., Sov. J. Quantum Electron. 11,13 .

3620. HIGH-POWER NEUTRAL-BEAM ANGULAR-DIVERGENCE EVALUATION FROM SPECTRALLY RESOLVED DOPPLER MEASUREMENTS. Bracco G., Breton C., Michelis C. de, Mattioli M., Ramette J., J. Opt. Soc. Am. 71, 1318.

3621. STARK BROADENING OF KRYPTON LINES. Brandt T., Helbig V., Nick K. P., "Spectral Line Shapes," 265-274 (Ed. B. Wende, Walter de Gruyter \& Co., New York, 1981).

3622. STUDY OF THE "BLUE" SATELLITE OBSERVED ON THE SELF-BROADENED $1849 \AA$ MERCURY LINE. EVIDENCE FOR A CHANGE IN THE TRANSITION DIPOLE MOMENT WITH INTERNUCLEAR DISTANCE. Bras N., Bousquet C., J. Phys. (Paris) 42, 215. (Fr.)

3623. THEORIES OF SPECTRAL LINE SHAPE. Breene R. G. Jr., "Theories of Spectral Line Shape," 1-344 (John Wiley \& Sons, New York, 1981).

3624. LASER SPECTROSCOPY OF PLASMAS IN APPLICATION TO MEASUREMENTS OF LINE SHAPES AND COLLISION RATES. Burgess D. D., "Spectral Line Shapes," 473-515 (Ed. B. Wende, Walter de Gruyter \& Co., New York, 1981).

3625. LONG PATH ABSORPTION MEASUREMENTS OF THE PRESSURE-BROADENED BALMER-ALPHA PROFIlE. Burgess D. D., Kolbe G., Playford C. St. Q., "Spectral Line Shapes," 119-133 (Ed. B. Wende, Walter de Gruyter \& Co., New York, 1981).

3626. TABLES FOR DIRECT DETERMINATION OF SPECTRAL LINE PARAMETERS, FROM SPECTROMETRIC DATA- I. PURE LORENTZ BROADENING. Claude M. L., Valentin A., J. Quant. Spectrosc. Radiat. Transfer 26, 349. 
3627. TUNABLE DYE LASER SPECTROSCOPY OF ATOMIC CALCIUM: COLLISIONAL REDISTRIBUTION OF RADIATION. Corney A., McGinley J. V. M., J. Phys. B 14,3047 .

3628. THEORY OF NEAR-RESONANCE SCATTERING OF A LASER BEAM ON ALKALI ATOMS PERTURBED BY A FOREIGN GAS. Czub J., Fiutak J., J. Phys. B 14, 39.

3629. COLLISIONALLY TRIGGERED GENERATION OF A COHERENT SIGNAL. Dagenais M., Phys. Rev. A 24, 1404.

3630. DISCREPANCY WITH THEORETICAL RESONANCE BROADENING ON THE He LINE AT 2.06 $\mu \mathrm{m}$. Damaschini R., Verges J., "Spectral Line Shapes," 857-863 (Ed. B. Wende, Walter de Gruyter \& Co., New York, 1981).

3631. NON-LINEAR BROADENING OBSERVED IN He AT MODERATE DENSITIES. Damaschini R., Verges J., Phys. Lett. A 87, 27.

3632. THE BROADENING OF SPECTRAL LINES BY AUTOIONIZATION, RADIATIVE TRANSITIONS, AND COLLISIONS. Davis J., Jacobs V. L., "Spectral Line Shapes," 275-280 (Ed. B. Wende, Walter de Gruyter \& Co., New York, 1981).

3633. QUASI-STATIC WINGS AND BLUE SATELLITE OF THE K(4S-5P) DOUBLET PERTURBED BY NEON. Delhoume M., Brillet W. -Ü L., Masnou-Seeuws F., Feautrier N., Rostas F., J. Phys. B 14, 3857.

3634. BLUE SATELlite OF THE K(5P-4S) DOUBLET PERTURBED BY NEON. Delhoume M., Brillet W. -Ü L., Masnou-Seeuws F., Feautrier N., Rostas F., "Spectral Line Shapes," 689-694 (Ed. B. Wende, Walter de Gruyter \& Co., New York, 1981).

3635. STARK BROADENING OF SOME O III LINES. Dimitrijevic M. S., Publ. Astron. Obs. Sarajevo 1, 215.

3636. ON THE STARK BROADENING OF IONIZED NITROGEN LINES. Dimitrijevic M. S., Konjevic N., J. Quant. Spectrosc. Radiat. Transfer 25, 387.

3637. COMPARISON BETWEEN QUANTUM AND SEMICLASSICAL CALCULATIONS OF THE ELECTRON IMPACT BROADENING OF THE Li I RESONANCE LINE. Dimitrijevic M. S., Feautrier N., Sahal-Bréchot S., J. Phys. B 14, 2559. 
3638. SEMIEMPIRICAL STARK LINEWIDTHS OF ALKALI LIKE IONS. Dimitrijevic M. S., Konjevic N., Astron. Astrophys. 102, 93.

3639. ELECTRON-IMPACT BROADENED LINE WIDTHS IN A SUPERMULTIPLET. Dimitrijevic M. S., "European Conference on Atomic Physics," 529-530 (Ed. J. Kowalski, G. zu Putlitz, H. G. Weber, European Physical Society, 1981).

3640. MODIFIED SEMIEMPIRICAL FORMULA FOR THE ELECTRON-IMPACT WIDTH OF IONIZED ATOM LINES: THEORY AND APPLICATIONS. Dimitrijevic M. S., Konjevic N., "Spectral Line Shapes," 211-239 (Ed. B. Wende, Walter de Gruyter \& Co., New York, 1981).

3641. THE LAST TRUTH ON PLASMA SATELLITES ?. Drawin H. W., "Spectral Line Shapes," 527-576 (Ed. B. Wende, Walter de Gruyter \& Co., New York, 1981).

3642. THE INFLUENCE OF THE GAS TEMPERATURE ON THE CENTRAL PART OF THE STARK PROFILE OF BALMER BETA. Esrom H., Helbig V., "Spectral Line Shapes," 135-140 (Ed. B. Wende, Walter de Gruyter \& Co., New York, 1981).

3643. ACCURATE CALCULATION OF DYNAMIC STARK SHIFTS AND DEPOPULATION RATES OF RYDBERG ENERGY LEVELS INDUCED BY BLACKBODY RADIATION. HYDROGEN, HELIUM, AND ALKALI-METAL ATOMS. Farley J. W., Wing W. H., Phys. Rev. A 23, 2397.

3644. BROADENING OF THE CAESIUM SECOND RESONANCE DOUBLET BY COLLISIONS WITH HYDROGEN MOLECULES. Ferray M., Visticot J. P., Lozingot J., Sayer B., J. Phys. B 14, 3875 .

3645. LINE PROFILE MEASUREMENTS OF RADIATION FROM THE MAGNETIC FIELD GLOW DISCHARGE SOURCE. Ferreira N. P., Kruger R. A., Human H. G. C., Spectrochim. Acta, Part B 36, 145.

3646. ALUMINUM LINES REDUCED TO A THIN LAYER IN AN OPTICALLY DENSE PLASMA. Fishman I. S., Salakhov M. Kh., Sarandaev E. V., Semin P. S., Opt. Spectrosc. (USSR) 51, 435.

3647. WIDTH OF ZEEMAN COMPONENTS OF SIMPLE ATOMIC LINES. Fourcade N., Lassale J., Roig J., J. Opt. (Paris) 12, 65.(Fr.)

3648. CONVOLUTION AND DECONVOLUTION OF FOCUSED BEAM DATA IN MULTIPHOTON DECOMPOSITION EXPERIMENTS. Francisco J. S., Steinfeld J. I., Gilbert R. G., Chem. Phys. Lett. 82, 311 . 
3649. STARK EFFECT FOR A CONFINED HYDROGEN ATOM. Friedman M., Rabinovitch A., Thieberger R., J. Phys. B 14, 4737.

3650. ASYMPTOTIC FORMS OF CONVOLVED LINE PROFILES. Froment N. M., Radmore P. M., Stephenson G., J. Phys. A 14, 2201.

3651. X-RAY SPECTROSCOPY OF THE CENTRAL LUMINOUS REGION OF A LASER-PRODUCED ALUMINUM PLASMA. Fujimoto T., Yamaguchi N., Mizui J., Kato T., Fujita J., J. Phys. D 14, 439.

3652. BLACKBODY-RADIATION-INDUCED STARK SHIFTS IN PERTURBED RYDBERG SERIES. Gallagher T. F., Sandner W., Safinya K. A., Cooke W. E., Phys. Rev. A $23,2065$.

3653. STARK BROADENING OF He I LINES IN A CO LASER-PRODUCED PLASMA. Gauthier J. C., Geindre J. P., Goldbach C1., Grand jouan N., Mazure A., Nollez G., J. Phys. B 14, 2099.

3654. STARK BROADENING OF THE HYDROGEN RESONANCE LINE $\mathrm{L}_{\gamma}$ IN COMPARISON TO $\mathrm{L}_{\alpha}$ AND $L_{\beta}$. Geisler M., Grützmacher K., Wende B., "Spectral Line Shapes," 103-117 (Ed. B. Wende, Walter de Gruyter \& Co., New York, 1981).

3655. EXPERIMENTAL DETERMINATION OF THE TOTAL INTEGRATED INTENSITY OF VARIOUS DOUBLETS OF CS ABSORPTION SERIES UNDER VARIOUS PRESSURES OF FOREIGN GASES. Gilbert D. E., Ch'en S. Y., J. Quant. Spectrosc. Radiat. Transfer 25,501 .

3656. BROADENING AND SHIFTS OF THE RESONANCE LINES OF NEUTRAL AND SINGLY IONIZED Mg, Ca AND Sr. Giles R. G., Lewis E. L., "Spectral Line Shapes," 733-740 (Ed. B. Wende, Walter de Gruyter \& Co., New York, 1981).

3657. TWO-PHOTON EXCITATION OF XENON ATOMS AND DIMERS IN THE ENERGY REGION OF THE $5 p^{5} 6 p$ CONFIgURATION. Gornik W., Kindt S., Matthias E., Schmidt D., J. Chem. Phys. 75, 68.

3658. EXPERIMENTAL STUDIES OF TWO-PHOTON ABSORPTION OF SODIUM PERTURBED BY COLLISIONS WITH NOBLE GAS ATOMS. Granier R., Charton G., Granier J., J. Quant. Spectrosc. Radiat. Transfer 26, 71.

3659. EXPERIMENTAL STUDY OF TWO-PHOTON ABSORPTION OF SODIUM PERTURBED BY COLLISIONS WITH NOBLE GAS ATOMS. Granier R., Charton G., Granier J., "Spectral Line Shapes," 721-731 (Ed. B. Wende, Walter de Gruyter \& Co., New York, 1981). 
3660. INTERMEDIATE COUPLING EFFECTS ON HELIUM-LIKE ION LINES FROM DENSE PLASMAS. Griem H. R., Kepple P. C., "Spectral Line Shapes," 391-396 (Ed. B. Wende, Walter de Gruyter \& Co., New York, 1981).

3661. INTERATOMIC POTENTIALS OF THE $\mathrm{Hg}-\mathrm{Kr}$ VAN DER WAALS MOLECULE. Grycuk T., Czerwosz E., Physica C (Amsterdam) 106, 431.

3662. QUASI-STATIC STARK PROFILES OF Hn $\alpha$ HYDROGEN LINES IN A PLASMA. Gulyaev S. A., Sholin G. V., Sov. Astron.--AJ 25, 602.

3663. ABSORPTION COEFFICIENTS FOR THE WING OF THE Sr RESONANCE LINE AT $4607 \AA$ BROADENED BY Ar AND Xe. Harima H., Fukuzo Y., Tachibana K., Urano Y., J. Phys. B 14, 3069 .

3664. DIAGNOSIS OF HIGH-DENSITY LASER COMPRESSED PLASMAS USING SPECTRAL LINE PROFILES. Hauer A., "Spectral Line Shapes," 295-332 (Ed. B. Wende, Walter de Gruyter \& Co., New York, 1981).

3665. THE ASYMPTOTIC FALL-OFF OF A STARK-BROADENED SPECTRAL LINE IN THE CLASSICAL PATH MODEL. Hegerfeldt G. C., Reibold R., Phys Lett. A 82, 340.

3666. EXPERIMENTAL STUDY OF PLASMA BROADENED He I LINES WITH FORBIDDEN COMPONENTS. Helbig V., Ehrich H., "Spectral Line Shapes," 179-190 (Ed. B. Wende, Walter de Gruyter \& Co., New York, 1981).

3667. INVESTIGATION OF THE STARK BROADENING OF BALMER- $\beta$. Helbig V., Nick K. P., J. Phys. B 14, 3573 .

3668. HIGH-ORDER CORRECTIONS TO THE THERMAL MICROFIELD IN A DENSE PLASMA. Held B., Deutsch C., Phys. Rev. A 24, 540.

3669. SECOND-ORDER CORRECTIONS TO THERMAL MICROFIELD IN DENSE PLASMAS. Held B., Deutsch C., "Spectral Line Shapes," 447-456 (Ed. B. Wende, Walter de Gruyter \& Co., New York, 1981).

3670. STARK BROADENING OF ISOLATED ION LINES BY PLASMAS: APPLICATION OF THEORY. Hey J. D., Breger P., "Spectral Line Shapes," 201-209 (Ed. B. Wende, Walter de Gruyter \& Co., New York, 1981).

3671. STARK BROADENING OF ISOLATED ION LINES BY PLASMAS: THEORY. HeY J. D., Breger P., "Spectral Line Shapes," 191-200 (Ed. B. Wende, Walter de Gruyter \& Co., New York, 1981). 
3672. ION TEMPERATURE MEASUREMENTS OF TURBULENTLY HEATED TOKAMAK PLASMA BY DOPPLER-BROADENING OF VISIBLE LINES IN TRIAM-1. Hiraki N., Nakamura K., Toi K., Itoh S., Jpn. J. Appl. Phys. 20, 183.

3673. COLLISION BROADENING AND SHIFT OF THE POTASSIUM 4P-7S AND 4P-5D LINES BY ARGON. Hohimer J. P., Phys. Rev. A 23, 1110.

3674. QUENCHING COLLISIONS OF RUBIDIUM IN THE nS ( $32 \leq n \leq 45)$ RYDBERG LEVELS WITH HELIUM. Hugon M., Fournier P. R., Prunelé E. de, J. Phys. B 14, 4041.

3675. EXPRESSIONS FOR THE COMPUTER-EVALUATION OF THE FOUR KERNEL FUNCTIONS FOR LINE FORMATION WITH DOPPLER AND LORENTZ PROFILES. Hummer D. G., J. Quant. Spectrosc. Radiat. Transfer 26, 187.

3676. DETERMINATION OF PLASMA ELECTRON DENSITIES FROM THE INTENSITY RATIO OF RESONANCE AND INTERCOMBINATION LINES OF HELIUM-LIKE IONS. Ilyukhin A. A., Kramida A. E., Peregudov G. V., Chirkov V. A., Sov. J. Quantum. Electron. 11,34 .

3677. SHIFT OF ${ }^{2} \mathrm{~S}_{1 / 2}$ HYPERFINE SPLITTINGS DUE TO BLACKBODY RADIATION AND ITS INFLUENCE ON FREQUENCY STANDARDS. I tano W. M., Lewis L. L., Wineland D. J., J. Phys. (Paris), Colloq. C8, 283.

3678. CONSTANTS FOR BROADENING AND SHIFT OF $\mathrm{D}_{1}$ AND $\mathrm{D}_{2}$ RUBIDIUM-87 LINES BY INERT GASES. Izotova S. L., Kantserov A. I., Frish M. S., Opt. Spectrosc. (USSR) 51, 107.

3679. PRESSURE SHIFTS AND BROADENINGS IN THE ARC SPECTRUM OF KRYPTON. Jackson D. A., J. Opt. Soc. Am. 71, 1064.

3680. THE INFLUENCE OF STATIC FIELDS ON THE DYNAMIC STARK SPECTRA OF HYDROGEN BALMER LINES. Janssen G. C. A. M., Jayakumar R., Granneman E. H. A., J. Phys. B 14, L51.

3681. AN EXPERIMENTAL STUDY OF THE COLLISIONAL BROADENING OF THE Na-D LINES BY Ar, $\mathrm{N}_{2}$, AND $\mathrm{H}_{2}$ PERTURBERS IN FLAMES AND VAPOR CELLS-I. THE LINE CORE. Jongerius M. J., Van Bergen A. R. D., Hollander Tj., Alkemade C. Th. J., J. Quant. Spectrosc. Radiat. Transfer 25, 1.

3682. AN EXPERIMENTAL STUDY OF THE COLLISIONAL BROADENING OF THE Na-D LINES BY Ar AND $\mathrm{N}_{2}$ PERTURBERS IN FLAMES AND VAPOR CELLS-II. THE LINE WINGS. Jongerius M. J., Hollander Tj., Alkemade C. Th. J., J. Quant. Spectrosc. Radiat. Transfer 26, 285. 
3683. STARK BROADENING OF Ar ${ }^{16}$ LINES IN DENSE LASER PRODUCED PLASMAS. Joyce R. F., Woltz L. A., Hooper C. F. Jr., Laser Interact. Relat. Plasma Phenomena 5, 819 .

3684. AN INVESTIGATION OF THE USE OF LINE WIDTHS IN QUANTITATIVE SPECTROGRAPHIC ANALYSIS. Kabiel A. M., Shoaeb A. M., Nasr F. I., Ali Y. M., Spectrochim. Acta, Part B 36, 129.

3685. MEASUREMENT OF A TOTAL ATOMIC-RADIATOR-PERTURBER SCATTERING CROSS SECTION. Kachru R., Chen T. J., Hartmann S. R., Mossberg T. W., Berman P. R., Phys. Rev. Lett. 47, 902.

3686. REPLY TO THE PRECEDING NOTE ON THE STARK BROADENING OF IONIZED NITROGEN LINES. Kallne E., Jones L. A., J. Quant. Spectrosc. Radiat. Transfer 25, 393.

3687. STARK BROADENING OF VISIBLE NEUTRAL HELIUM LINES IN A PLASMA. Kelleher D. E., J. Quant. Spectrosc. Radiat. Transfer 25, 191.

3688. MULTIPLE PERTURBER SATELLITES: THEORY AND EXPERIMENT. Kielkopf J. F., "Spectral Line Shapes," 665-688 (Ed. B. Wende, Walter de Gruyter \& Co., New York, 1981).

3689. IMPACT BROADENING OF THE 4p-7s TRANSITIONS IN POTASSIUM BY HELIUM AND ARGON. Kielkopf J. F., Knollenberg R., J. Phys. B 14, 1263.

3690. EMISSION LINE SHAPES FROM LASER COMPRESSION PLASMAS. Kilkenny J., Veats S., Shalom A., Lee R. W., "Spectral Line Shapes," 367-372 (Ed. B. Wende, Walter de Gruyter \& Co., New York, 1981).

3691. A COMPARISON OF METHODS FOR THE CALCULATION OF VOIGT PROFILES. KIIm A., J. Quant. Spectrosc. Radiat. Transfer 26, 537.

3692. KINETIC THEORY OF THE BROADENING OF SPECTRAL LINES IN PLASMAS. Klimontovich Yu. L., Sukhin S. A., Theor. Math. Phys. (USSR) 47, 334.

3693. MEASUREMENT OF THE PROBABILITIES OF FORBIDDEN RADIATIVE TRANSITIONS IN THE BARIUM ATOM. Klimovskii I. I., Minaev P. V., Morozov A. V., Opt. Spectrosc. (USSR) $50,464$. 
3694. ON THE SYSTEMATIC TRENDS OF STARK BROADENING PARAMETERS OF ISOLATED LINES IN PLASMAS. Konjevic N., Dimitrijevic M. S., "Spectral Line Shapes," 241-248 (Ed. B. Wende, Walter de Gruyter \& Co., New York, 1981).

3695. INTERACTION OF METASTABLE MERCURY ATOMS WITH GROUND-STATE INERT-GAS ATOMS. Kryukov N. A., Penkin N. P., Redko T. P., Opt. Spectrosc. (USSR) 51,420 .

3696. INVESTIGATION OF PLASMA-SATELLITES BY LASER-FLUORESCENCE SPECTROSCOPY. Kunze H. J., "Spectral Line Shapes," 517-526 (Ed. B. Wende, Walter de Gruyter \& Co., New York, 1981).

3697. DISTRIBUTION FUNCTIONS OF A MICROFIELD IN NONIDEAL PLASMA. Kurilenkov Yu. K., Filinov V. S., High Temp. (USSR) 18, 509.

3698. STARK WIDTHS AND SHIFTS SYSTEMATIC TRENDS. Lakicevic I. S., Puric J., "Fifteenth International Conf. on Phenomena in Ionized Gases, Contributed Papers," 915-916 (Minsk, 1981).

3699. STARK BROADENING AND SHIFT OF Cs I AND Al II LINES. Lakicevic I. S., Puric J., Cuk M., "Spectral Line Shapes," 253-256 (Ed. B. Wende, Walter de Gruyter \& Co., New York, 1981).

3700. A HOLLOW CATHODE FOR DOPPLER-FREE SPECTROSCOPY. Lawler J. E., Siegel A., Couillaud B., Hänsch T. W., J. Appl. Phys. 52, 4375.

3701. ABEL'S INVERSION OF A CYLINDRICAL HELIUM PLASMA. PRODUCTION OF STIGMATIC SPECTROGRAPH USING A VIDICON DETECTOR. Le Toulouzan J. N., Locquet J. J., Allano D., Savary P., Darrigo R., J. Opt. (Paris) 12, 369.(Fr.)

3702. DYNAMIC ASPECT OF COLLISIONS IN ATOMIC LINE PROFILE COMPUTATION. APPLICATION TO THE RESEARCH OF Hg $\left(6{ }^{3} \mathrm{P}_{1}\right)$-HEAVY, NOBLE GAS INTERATOMIC POTENTIALS. Leboucher E., J. Phys. (Paris) 42, 813.(Fr.)

3703. LINE SHAPES OF LITHIUM-LIKE IONS EMITTED FROM PLASMAS. Lee R. W., Matthews D. L., Scofield J., J. Phys. B 14, 3079.

3704. THE POLARIZATION OF COLLISIONALLY REDISTRIBUTED FLUORESCENCE RESULTING FROM LINE WING EXCITATION. Lewis E. L., Salter J. M., Harris M., J. Phys. B 14, L173. 
3705. COLLISION BROADENING AND SHIFT OF THE $535.0 \mathrm{~nm}$ TI LINE ACCOMPANYING THE PHOTODISSOCIATION OF THALLIUM IODIDE PERTURBED BY NOBLE GASES: Part II: EFFECTS DUE TO He, Ne AND Ar. Lisicki E., Bielski A., Szudy J., Z. Naturforsch., Teil A 36, 807.

3706. USE OF SELF-REVERSED CONTOURS TO DETERMINE THE SOURCE FUNCTION AND THE ORIGINAL PROFILE. Luizova L. A., Trukhacheva V. A., Opt. Spectrosc. (USSR) 51, 429.

3707. SHAPE OF A SUPERRADIATION SPECTRUM. Malikov R. F., Malyshev V. A., Trifonov E. D., Opt. Spectrosc. (USSR) 51, 225.

3708. GENERALIZED LORENTZIAN APPROXIMATIONS FOR THE VOIGT LINE SHAPE. Martin P., Puerta J., Appl. Opt. 20, 259.

3709. MODEL POTENTIAL CALCULATIONS FOR ALKALI RARE-GAS SYSTEMS. COMPARISON WITH EXPERIMENT. Masnou-Seeuws F., "Spectral Line Shapes," 593-613 (Ed. B. Wende, Walter de Gruyter \& Co., New York, 1981).

3710. THE HYDROGEN BALMER- $\alpha$ LINE PROFILE IN RF-DISCHARGE PLASMAS. Matsunaga K., Kadota K., Fujiwara M., Fujita J., Jpn. J. Appl. Phys. 20, L615.

3711. APPROXIMATE REPRESENTATIONS OF THE REFRACTIVE INDEX OF A MEDIUM IN THE REGION OF A VOIGT-PROFILE ABSORPTION LINE. Matveev V. S., J. Appl. Spectrosc. (USSR) 35, 1043.

3712. DICKE NARROWING REDUCTION OF THE DOPPLER CONTRIBUTION TO A LINE WIDTH. McMahon D. R. A., Aust. J. Phys. 34, 639.

3713. A STUDY OF PARTIAL FREQUENCY REDISTRIBUTION OF MONOCHROMATIC SOURCE RADIATION. Meier R. R., J. Quant. Spectrosc. Radiat. Transfer 25, 137.

3714. A SPECTROMETRIC STUDY OF A $40 \mathrm{MHz}$ INDUCTIVELY COUPLED PLASMA - V. DISCUSSION OF SPECTRAL INTERFERENCES AND LINE INTENSITIES. Mermet J. M., Trassy C., Spectrochim. Acta, Part B 36, 269.

3715. THE MEASUREMENT OF COLLISIONAL LINESHAPES USING OPTICAL ECHO TECHNIQUES. Mossberg T. W., Kachru R., Leung K. P., Whittaker E., Hartmann S. R., "Spectral Line Shapes," 1093-1111 (Ed. B. Wende, Walter de Gruyter \& Co., New York, .1981). 
3716. SPECTRAL LINE PROFILES OF NEUTRAL ARGON IN THE NEAR INFRARED SPECTRAL REGION. Musielok J., Beitr. Plasmaphys. 21, 179.(Ger.)

3717. COLLISION-INDUCED DIPOLE TRANSITIONS AND COLLISIONAL BROADENING OF QUADRUPOLE TRANSITIONS. Nayfeh M. H., Glab W., McCown A., Phys. Rev. A 24, 1142 .

3718. BROADENING OF HYDROGENIC X RAYS EMITTED BY A LASER-PRODUCED PLASMA. Nguyen Hoe, "Spectral Line Shapes," 397-431 (Ed. B. Wende, Walter de Gruyter \& Co., New York, 1981).

3719. LINE BROADENING BY HOT AND DENSE PLASMAS. Nguyen Hoe, Grumberg J., Caby M., Leboucher E., Coulaud G., Phys. Rev. A 24, 438.

3720. POLARIZATION SHIFT OF LOW-Z BALMER LINES IN LASER-PRODUCED PLASMAS. Nicolosi P., Volonté S., J. Phys. B 14, 585.

3721. ABSORPTION SPECTRUM OF A DRIVEN ATOM IN A PERTURBER GAS. Nienhuis G., J. Phys. B 14, 1963.

3722. ASYMPTOTIC LINE SHAPE FOR COLLISION-INDUCED DEPOLARIZED LIGHT SCATTERING IN ATOMIC GASES. Ovsiannikov V. D., Phys. Lett. A 85, 275.

3723. PROBLEM OF THE INFLUENCE OF "STRONG" COLLISIONS OF PLASMA ELECTRONS WITH HYDROGEN ATOM ON THE BROADENING OF ITS SPECTRAL LINES. Pargamanik L. E., Ginzburg M. D., J. Appl. Spectrosc. (USSR) 33, 808.

3724. THE REDSHIFT OF HYDROGEN LINES IN A STRONG MAGNETIC FIELD. Patil S. H., J. Phys. A $14 ; 2251$.

3725. THEORY OF THE PRESSURE BROADENING AND SHIFT OF SPECTRAL LINES. Peach G., Adv. Phys. 30, 367.

3726. IS ION DYNAMICS REALLY SO IMPORTANT ?. Peach G., "Spectral Line Shapes," 91-102 (Ed. B. Wende, Walter de Gruyter \& Co., New York, 1981).

3727. COMPLETE SPECTRAL PROFILE OF THE $6{ }^{1} \mathrm{~S}_{0}-6{ }^{3} \mathrm{P}_{1}$ MERCURY LINE PERTURBED BY ARGON. Perrin D., Jeannet J. C., J. Phys. (Paris) 42, 1607.

3728. SELF-BROADENING IN METAL VAPORS. Pichler G., "Spectral Line Shapes," 827-844 (Ed. B. Wende, Walter de Gruyter \& Co., New York, 1981). 
3729. THE PROBLEM OF MOLECULAR LINES IN THE STUDY OF PLASMA SATELLITES. Piel A., "Spectral Line Shapes," 577-589 (Ed. B. Wende, Walter de Gruyter \& Co., New York, 1981).

3730. SOME COMMENTS ON HYDROGENIC LINES IN A PLASMA - SHIFTS, ASYMMETRIES AND WIDTHS. Pittman T. L., Kelleher D. E., "Spectral Line Shapes," 165-176 (Ed. B. Wende, Walter de Gruyter \& Co., New York, 1981).

3731. EMPIRICAL LINESHAPE FOR COMPUTER FITTING OF SPECTRAL DATA. Price D. C., Aust. J. Phys. 34, 51.

3732. THREE AND FOUR GENERALIZED LORENTZIAN APPROXIMATIONS FOR THE VOIGT LINE SHAPE. Puerta J., Martin P., Appl. Opt. 20, 3923; 22, 19 (1983).

3733. THEORETICAL QUASAR EMISSION LINE RATIOS. IV. GENERAL ASYMPTOTIC ESCAPE PROBABILITIES AND THE EFFECTS OF LINEAR STARK BROADENING. Puetter R. C., Astrophys. J. 251, 446 .

3734. REGULARITIES AND TRENDS IN STARK PARAMETERS OF NEUTRAL AND ION SPECTRAL LINES. Puric J., "Fifteenth International Conference on Phenomena in Ionized Gases, Invited Papers," 311-320 (Minsk, 1981).

3735. STARK PARAMETER DEPENDENCE ON THE IONIZATION POTENTIAL. Puric J., Labat O., Lakicevic I. S., "Spectral Line Shapes," 249-252 (Ed. B. Wende, Walter de Gruyter \& Co., New York, 1981).

3736. SOME REGULARITIES WITHIN THE STARK WIDTHS AND SHIFTS OF RESONANCE ION LINES FROM Li TO Ca. Puric. J., Lakicevic I. S., Glavonic V., J. Quant. Spectrosc. Radiat. Transfer 26, 65.

3737. STARK WIDTH AND SHIFT PERIODIC DEPENDENCE ON NUCLEAR CHARGE NUMBER. Puric J., Lakicevic I. S., "Fifteenth International Conf. on Phenomena in Ionized Gases, Contributed Papers," 927-928 (Minsk, 1981).

3738. UNIFIED THEORY OF PRESSURE BROADENED ABSORPTION SPECTRA IN STRONG RADIATION FIELDS. Rabin Y., Mukamel S., "Spectral Line Shapes," 945-953 (Ed. B. Wende, Walter de Gruyter \& Co., New York, 1981).

3739. SPECTRAL LINE BROADENING DUE TO THE INTERACTION BETWEEN VERY EXCITED ATOMS: "THE DENSE RYDBERG GAS". Raimond J. M., Vitrant G., Haroche S., J. Phys. B 14, L655. 
3740. ION BROADENING ON THE WINGS OF LYMAN- $\alpha$. Rang L. Q., Voslamber D., J. Quant. Spectrosc. Radiat. Transfer 25, 35.

3741. A GREEN'S FUNCTION APPROACH TO THE SHIFT OF SPECTRAL LINES IN DENSE PLASMAS. Röpke G., Seifert T., Kilimann K., Ann. Physik (Leipzig), 38, 381.

3742. COMPUTER DIAGNOSTICS OF AN OPTICALLY DENSE PLASMA FROM ABSORPTION SPECTRA. Salakhov M. Kh., Fishman I. S., Semin P. S., Sarandaev E. V., Sov. Phys. J. 24, 584.

3743. USE OF RADIATIVE LINE BROADENING BY AN INTENSE LASER FIELD AS A PLASMA DIAGNOSTIC. Schlessinger L., Wright J., Phys. Rev. Lett. 47, 519.

3744. THEORY OF HYDROGEN STARK BROADENING. Seidel J., "Spectral Line Shapes," 3-40 (Ed. B. Wende, Walter de Gruyter \& Co., New York, 1981).

3745. AN ANALYSIS OF MARKOVIAN MODEL MICROFIELD METHODS FOR STARK BROADENING. Smith E. W., Talin B., Cooper J., J. Quant. Spectrosc. Radiat. Transfer 26,229 .

3746. OSGILLATOR STRENGTHS AND COLLISIONAL DAMPING PARAMETERS FOR LINES OF NEUTRAL CALCIUM. Smith G., Raggett D. St. J., J. Phys. B 14, 4015.

3747. EXCITATION OF ATOMS AND BROADENING OF SPECTRAL LINES. Sobe1'man I. I., Vainshtein L. A., Yukov E. A., "Excitation of Atoms and Broadening of Spectral Lines," Vol. 7, Ch. 7, 239-303 (Eds. V. I. Goldanskii, R. Gomer, F. P. Schafer \& J. P. Toennies, Springer-Verlag, New York, 1981).

3748. TEMPERATURE DEPENDENCE OF THE Na-He COLLISION BROADENING CONSTANTS IN THE IMPACT REGION OF THE LINE PROFILE. Spielfiedel A., Roueff E., J. Phys. B 14, L795.

3749. BROADENING AND SHIFT OF HIGH RYDBERG STATES MEASURED BY DOPPLER-FREE TWO-PHOTON SPECTROSCOPY. Stoicheff B. P., Thompson D. C., Weinberger E., "Spectral Line Shapes," 1071-1082 (Ed. B. Wende, Walter de Gruyter \& Co., New York, 1981).

3750. CALCULATIONS OF SPECTRAL-LINE ELECTRONIC BROADENING IN THE THEORY OF PLASMA OPTICAL PROPERTIES. Syrkin M. I., Opt. Spectrosc. (USSR) 51, 431. 
3751. QUASIMOLECULAR INTERPRETATION OF COLLISION EFFECTS ON ATOMIC FORBIDDEN TRANSITIONS. Szudy J., Visticot J. P., Sayer B., "Spectral Line Shapes," 631-650 (Ed. B. Wende, Walter de Gruyter \& Co., New York, 1981).

3752. ANGULAR FACTORS IN $\left(j_{c} 1\right)$-COUPLING FOR THE QUADRUPOLE CONTRIBUTIONS TO THE WIDTH OF STARK BROADENED SPECTRAL LINES. Truong-Bach, Drawin H. W., J. Quant. Spectrosc. Radiat. Transfer 25, 285.

3753. STARK BROADENING OF NEUTRAL XENON. Truong-Bach, Richou J., Lesage A., Miller M. H., Phys. Rev. A 24, 2550.

3754. MEASUREMENT OF COLLISION BROADENING OF RESONANCE LINES OF CALCIUM ION BY A LOW-RESOLUTION SPECTROMETER. Urano Y., Monju M., Harima H., Tachibana K., Jpn. J. Appl. Phys. 20, 1021.

3755. QUASI-STATIC WINGS OF K SPECTRAL LINES BROADENED BY Cs. Vadla C., Beuc R., Movre M., "Spectral Line Shapes," 751-755 (Ed. B. Wende, Walter de Gruyter \& Co., New York, 1981).

3756. LINE SHAPE ANALYSIS FOR FABRY-PEROT INTERFEROMETER MEASUREMENTS. Valentini H. B., Exp. Tech. Phys. 29, 563.

3757. BROADENING AND SHIFTS OF THE XENON LINE AT $\lambda=3.51 \mu \mathrm{m}$ : MEASUREMENTS AND THEORETICAL INTERPRETATION. Vallée O., Marié E., Tran Minh N., Vetter R., Phys. Rev. A 24, 1391.

3758. DETERMINATION OF PERTURBATIONS IN THE SEMI-DEGENERATE $4 \mathrm{f} 4 \mathrm{~d} 4 \mathrm{p}-2 \mathrm{p}$ Li I LINE EMITTED BY AN ELECTROLYTIC PLASMA. Valognes J. C., Mergault P., J. Quant. Spectrosc. Radiat. Transfer 25, 471.

3759. GIANT STARK BROADENING OF ATOMIC GALLIUM EMISSION LINES NEAR A HIGH FIELD TIP. Venkatesan T., Wagner A., Nash D. L., Mungo A. J., Barr D., App1. Phys. Lett. $39,9$.

3760. LINE SHAPES IN LASER EXPERIMENTS. Vetter R., Berman P. R., Comments At. Mo1. Phys. 10, 69.

3761. QUASISTATIC SELF-BROADENING OF Li AND Na FIRST RESONANCE LINES. Veza D., Pichler G., "Spectral Line Shapes," 845-850 (Ed. B. Wende, Walter de Gruyter \& Co., New York, 1981). 
3762. EXPERIMENTAL STUDY OF THE SATELLITE OF THE Cs(6 $\left.\mathrm{s}_{1 / 2}-5 \mathrm{D}_{5 / 2}\right)$ LINE PERTURBED BY A RARE GAS AND COMPARISON WITH THE PREDICTIONS OF A QUASIMOLECULAR MODEL. Visticot J. P., Szudy J., Ferray M., Sayer B., J. Phys. B 14, 4755 .

3763. SEMICLASSICAL DESCRIPTION OF THE SATELLITE PROFILE OF THE Cs $\left(6 \mathrm{~S}_{1 / 2}-5 \mathrm{D}_{5 / 2}\right)$ TRANSITION PERTURBED BY ARGON ALLOWING MOLECULAR POTENTIAL DETERMINATION. Visticot J. P., Szudy J., Sayer B., J. Phys. B 14, 2329.

3764. THEORY INCLUDING NON-ADIABATIC EFFECTS OF ION DYNAMICS. Voslamber D., "Spectral Line Shapes," 73-89 (Ed. B. Wende, Walter de Gruyter \& Co., New York, 1981).

3765. ION DYNAMIC CORRECTION TO THE PROFILE OF THE FORBIDDEN $2{ }^{3} \mathrm{P}-4^{3} \mathrm{~F}$ TRANSITION OF He I. Voslamber D., Segre E. R. A., J. Quant. Spectrosc. Radiat. Transfer, 25, 45.

3766. INFLUENCE OF DIFFERENT ION DYNAMICAL EFFECTS ON LYMAN LINES. Voslamber D., Stamm R., "Spectral Line Shapes" 63-72, (Ed. B. Wende, Walter de Gruyter and Co., New York, 1981).

3767. LINE-SHAPE CHANGES DUE TO OPTICAL PUMPING OF Na IN BUFFER GAS. Walkup R. E., Spielfiedel A., Phillips W. D., Pritchard D. E., Phys. Rev. A 23, 1869.

3768. PRESSURE-BROADENING RATES FROM THE NEAR-WING AMPLITUDE. Walkup R. E., Spielfiedel A., Ely D., Phillips W. D., Pritchard D. E., J. Phys. B 14, 1953.

3769. COLLISION STUDIES OF H $\alpha$ FINE STRUCTURE LINES WITH HIGH-RESOLUTION LASER SPECTROSCOPY. Weber E.. W., "Spectral Line Shapes," 1113-1122 (Ed. B. Wende, Walter de Gruyter \& Co., New York, 1981).

3770. PLASMA SHIFT AND BROADENING OF SINGLE HYDROGEN BALMER- $\alpha$ FINE-STRUCTURE LINES. Weber E. W., Humpert H. J., Phys. Lett. A 83, 386.

3771. PLASMA SHIFT AND BROADENING OF RESOLVED H $\alpha$ FINE STRUCTURE LINES. Weber E. W., Humpert H. J., "Spectral Line Shapes," 1133-1140 (Ed. B. Wende, Walter de Gruyter \& Co., New York, 1981). 
3772. INFLUENCE OF ELASTIC AND INELASTIC COLLISIONS ON DENSITY SHIFT AND BROADENING. Weber E. W., Jungmann K., Phys. Lett. A 81, 223.

3773. EFFECT OF QUENCHING COLLISIONS ON DENSITY SHIFT AND BROADENING. Weber E. W., Jungmann K., "Spectral Line Shapes," 1123-1131 (Ed. B. Wende, Walter de Gruyter \& Co., New York, 1981).

3774. VOIGT PROFILES OF SPECTRAL LINES: ACCURACY OF LINE PARAMETERS AS A FUNCTION OF PEAK TRANSMITTANCE. Wilczek E., Belbruno J. J., Gelfand J., Appl. Spectrosc. 35, 443.

3775. LINE BROADENING CAUSED BY LASER LINEWIDTH. Wodkiewicz K., "Spectral Line Shapes," 955-961 (Ed. B. Wende, Walter de Gruyter \& Co., New York, 1981).

3776. STARK BROADENING IN HOT, DENSE, LASER-PRODUCED PLASMAS: FULL COULOMB ELECTRON INTERACTIONS. Woltz L. A., Joyce R. F., Hooper C. F. Jr., "Spectral Line Shapes," 379-389 (Ed. B. Wende, Walter de Gruyter \& Co., New York, 1981).

3777. CALCULATED PRESSURE BROADENING AND SHIFT FOR THE SODIUM ATOM PERTURBED BY RARE GASES. II. TWO-PHOTON 3S-nS TRANSITIONS $(n=6-9)$. Wu C. Y. R., Stwalley W. C., Phys. Rev. A 24, 1117.

3778. ELECTRON SCATTERING CONTRIBUTION TO THE RED SHIFT OF He II'LINES IN .PLASMA. Yamamoto K., Narumi H., Phys. Lett. A 86, 142.

37.79. REDISTRIBUTION OF RADIATION FOR THE WINGS OF LYMAN- $\alpha$. Yelnik J.-B., Burnett.K., Cooper J., Ballagh R. J., Voslamber D., Astrophys. J. 248, 705 .

3780. ON THE VOIGT ANALYSIS OF INTERFEROGRAMS BY USING BALLIK'S METHOD. Zhechev D., Zaprianova R., Koleva I., Spectrosc. 'Lett. 14, 809.

3781. LOW-TEMPERATURE He-Na COLLISION RATE MEASUREMENTS. Zimmermann M., Miles R. B., J. Phys. B 14, L85.

3782. PLASMA SHIFTS OF C VI LYMAN LINES TO SHORTER WAVELENGTHS. Adcock J. C. Jr., Griem H. R., University of Maryland, Plasma preprint PL 非3-024 (1982). 
3783. COLLISIONAL BROADENING OF INTRA-DOPPLER RESONANCES OF SELECTIVE REFLECTION ON THE $D_{2}$ LINE OF CESIUM. Akul'shin A. M., Velichanskii V. L., Zibrov A. S., Nikitin V. V., Sautenkov V. V., Yurkin E. K., Senkov N. V., JETP Lett. 36, 303.

3784. EFFECTS OF BROADENING MECHANISMS ON ATOMIC RESONANCE FLUORESCENCE. Al-Hilfy A., Loudon R., J. Phys. B 15, 2819.

3785. EFFECT OF THE VELOCITIES OF THE PERTURBERS ON ALKALI-RARE GAS LINE PROFIlES. Allard N. F., Biraud Y. G., J. Phys. (Paris) 43, 501.

3786. THE EFFECT OF NEUTRAL NONRESONANT COLLISIONS ON ATOMIC SPECTRAL LINES. Allard N. F., Kielkopf J. F., Rev. Mod. Phys. 54, 1103.

3787. CALCULATION OF GAIN AT X-RAY WAVELENGTHS RESULTING FROM OPTICAL PUMPING OF HELIUM-LIKE IONS. Alley W. E., Chapline G., Kunasz P., Weisheit J. C., J. Quant. Spectrosc. Radiat. Transfer 27, 257.

3788. RARE GAS COLLISIONAL PERTURBATION OF THE 6s6d LEVELS OF MERCURY: EXPERIMENTAL. Arbadji S. A., Hennecart D., Lecler D., J. Phys. (Paris) 43,37 .

3789. INVESTIGATION OF THE ALIGNMENT OF THE ${ }^{2} \mathrm{D}_{5 / 2}$ STATE OF Cd II IN A GAS DISCHARGE. Atadzhanov M. R., Kotlikov E. I/2, Chaika M. P., Opt. Spectrosc. (USSR) 53, 378.

3790. EXPERIMENTAL A ${ }^{2} \pi$ POTENTIALS FOR Li-He AND Li-Ne MOLECULES. Balling L. C., Wright J. J., Havey M. D., Phys. Rev. A 26, 1426.

3791. CONVERGENT CALCULATIONS FOR ELECTRON IMPACT BROADENING AND SHIFT OF NEUTRAL HELIUM LINES. Bassalo J. M., Cattani M., Walder V. S., J. Quant. Spectrosc. Radiat. Transfer 28, 75.

3792. STARK BROADENING OF ISOLATED UV LINES OF Li I, AI I AND Si I BY A DC ARC PLASMA WITHOUT AND WITH Cs. Bassyouni A. H., Proc. Math. Phys. Soc. Egypt. 54, 17.

3793. CONTRIBUTION OF HYPERFINE-INTERACTION NONCONTACT TERMS TO LINE SHIFTS OF HYPERFINE TRANSITIONS IN THE GROUND STATE OF ALKALI ATOMS AND HYDROGEN. Batygin V. V., Sokolov I. M., Opt. Spectrosc. (USSR) 52, 448. 
3794. EXPERIMENTAL TEST OF THE ACCURACY OF A MAGNETIC-SCANNING DETERMINATION OF THE BROADENING AND SHIFT OF THE RUBIDIUM D LINE. Belov V. N., Romanenko E. V., Opt. Spectrosc. (USSR) 52, 441.

3795. COLLISION KERNELS AND LASER SPECTROSCOPY. Berman P. R., Mossberg T. W., Hartmann S. R., Phys. Rev. A 25, 2550.

3796. SATELLITE BANDS IN THE FAR BLUE WING OF THE POTASSIUM FIRST RESONANCE DOUbLeT. Beuc R., Milosevic S., Movre M., Pichler G., Veza D., Fizika (Zagreb) 14, 345 .

3797. BLUE ASYMMETRY OF POTASSIUM RESONANCE LINES BROADENED BY CAESIUM ATOMS. Beuc R., Movre M., Vadla C., J. Phys. B 15, 1333.

3798. COLLISION BROADENING AND SHIFT OF THE S AND D RYDBERG LEVELS OF RUBIDIUM BY He AND Ar. Bruce D. M., Mirza M. Y., Duley W. W., Opt. Commun. 40, 347.

3799. HIGH DENSITY PLASMA EFFECTS ON ATOMIC AND IONIC SPECTRA. Burgess D. D., Lee R. W., J. Phys. (Paris) Colloq. C2 43, 413.

3800. COLLISIONAL REDISTRIBUTION OF RADIATION IN STRONG FIELDS: MODIFICATION OF THE COLLISION DYNAMICS . Burnett K., Cooper J., Kleiber P. D., Ben-Reuven A., Phys. Rev. A 25, 1345.

3801. QUASISTATIC, ADIABATIC, AND IMPACT CALCULATIONS FOR THE ION BROADENING AND SHIFT OF NEUTRAL-HELIUM LINES IN A HOT PLASMA. Cattani M., Walder V. S., Phys. Rev. A 25, 3411.

3802. A MODEL FOR THE SPECTRAL LINE POLARIZATION SHIFT IN DENSE PLASMA. Cauble R., J. Quant. Spectrosc. Radiat. Transfer 28, 41.

3803. SPECTROSCOPIC INVESTIGATION OF THE HELIUM PLASMA PRODUCED BY LINEAR FOCUSING OF A TEA-CO ${ }_{2}$ LASER BEAM. Cirkovic Lj. M., Vujicic B. T., Glisic S. M., J. Phys. D 15, 229.

3804. ON REDISTRIBUTION AND THE EQUATIONS FOR RADIATIVE TRANSFER. Cooper J., Ballagh R. J., Burnett K., Hummer D. G., Astrophys. J. 260, 299.

3805. COMMENT ON THE USE OF AN EXPONENTIAL APPROXIMATION FOR THE STARK BROADENING OF HYDROGEN LINES. Cooper J., Smith E. W., J. Quant. Spectrosc. Radiat. Transfer 27, 665. 
3806. ELECTRON DENSITY MEASUREMENTS IN A LOW PRESSURE DISCHARGE USING DOPPLER-FREE TWO-PHOTON SPECTROSCOPY. Cornelissen H. J., Burgmans A. L. J., Opt. Commun. 41, 187.

3807. COLLISIONAL EFFECTS AND TWO-PHOTON ABSORPTION IN CALCIUM VAPOR. Corney A., McGinley J. V. M., J. Phys. B 15, L655.

3808. COLLISIONALLY INDUCED COHERENT SIGNALS AND COLLISIONAL REDISTRIBUTION. Dagenais M., Phys. Rev. A 26, 869.

3809. DIPOLE AUTOCORRELATION FUNCTION FOR MOLECULAR PRESSURE BROADENING: A QUANTUM THEORY WHICH SATISFIES THE FLUCTUATION-DISSIPATION THEOREM. Davies R. W., Tipping R. H., Clough S. A., Phys. Rev. A 26, 3378.

3810. LEVEL SHIFTS AND INELASTIC ELECTRON SCATTERING IN DENSE PLASMAS. Davis J., Blaha M., J. Quant. Spectrosc. Radiat. Transfer 27, 307.

3811. CHARACTERIZATION OF NON-LORENTZIAN LINE SHAPES IN ATOM-ATOM COLLISIONS. Dehesa J. S., Nuovo Cimento Soc. Ita1. Fis. D 1, 442.

3812. HIGH ACCURACY DECONVOLUTION METHOD USING SPLINE FUNCTIONS. Deutsch M., Beniaminy I., Rev. Sci. Instrum. 53, 90.

3813. SEMICLASSICAL CALCULATIONS OF ELECTRON IMPACT STARK WIDTHS OF S III, C1 II AND S IV ISOLATED LINES. Dimitrijevic M. S., Konjevic N., J. Quant. Spectrosc. Radiat. Transfer 27, 203.

3814. STARK BROADENING OF HEAVY ION SOLAR LINES. Dimitrijevic M. S., "Sun and Planetary System," 101-102 (Ed. W. Fricke \& G. Teleki, D. Reide1, Dordrecht, 1982).

3815. INFLUENCE OF DIFFERENT KINDS OF COLLISIONS ON THE STARK BROADENING OF THE Li I RESONANCE LINE. Dimitrijevic M. S., Feautrier N., Sahal-Bréchot S., "Symposium on the Physics of Ionized Gases, Contributed Papers," 277-280 (Dubrovnik, 1982).

3816. STARK BROADENING OF THE He I RESONANCE LINES. Dimitrijevic M. S., Sahal-Bréchot S., "Symposium on the Physics of Ionized Gases, Contributed Papers," 273-276 (Dubrovnik, 1982). 
3817. RESONANT SCATTERING (AUTOIONIZATION) CONTRIBUTION TO STARK BROADENING OF ION LINES. Dimitrijevic M. S., Cornille M., Feautrier N., Sahal-Bréchot S., "Symposium on the Physics of Ionized Gases, Contributed Papers," 281-283 (Dubrovnik, 1982).

3818. ON THE VARIATION OF STARK LINE WIDTHS WITHIN A SUPERMULTIPLET. Dimitrijevic M. S., Astron. Astrophys. 112, 251.

3819. PLASMA SATELLITES IN THE PRESENCE OF NON-RESONANT, COHERENT AND POLARIZED RADIATION. Drawin H. W., Truong-Bach, J. Phys. B 15, 4477; 17, 1927 (1984).

3820. A.C. STARK EFFECT ON THE $4713 \AA$ LINE EMITTED BY A HELIUM GLOW DISCHARGE IN THE FIELD OF A MULTIMOdE T.E.A. $\mathrm{CO}_{2}$ LASER. Dubreuil B., Pignolet P., Catherinot A., Davy P., J. Phys. (Paris) 43, 875.

3821. THEORY OF DEGENERATE FOUR-WAVE MIXING IN RESONANT DOPPLER-BROADENED MEDIA. II.DOPPLER-FREE HETERODYNE SPECTROSCOPY VIA COLLINEAR FOUR-WAVE MIXING IN TWO- AND THREE-LEVEL SYSTEMS. Ducloy M., Bloch D., J. Phys. (Paris) 43, 57.

3822. ON THE ${ }^{2} \mathrm{P}$ POTENTIALS FOR THE INTERACTION OF $\mathrm{K}(4 \mathrm{P})$ and $\mathrm{K}(5 \mathrm{P})$ WITH ARGON. Düren R., Hasselbrink E., Tischer H., Milosevic S., Pichler G., Chem. Phys. Lett. 89, 218.

3823. COMPARISONS OF SODIUM: RARE-GAS POTENTIALS BY MEASUREMENTS OF EXCITED-STATE DEGENERATE FOUR-WAVE MIXING. Ewart P., O'Leary S. V., J. Phys. B 15, 3669 .

3824. TRANSPORT OF RESONANCE EXCITATION IN Na VAPOR EXCITED BY WHITE LIGHT. Fujimoto T., Phelps A. V., Phys. Rev. A 25, 322.

3825. OSCILLATOR STRENGTH AND RARE-GAS INDUCED BROADENING OF THE ELECTRIC-QUADRUPOLE TRANSITION $4 \mathrm{~s}^{2} \mathrm{~S}_{0}-4 \mathrm{~s} 3 \mathrm{~d}^{1} \mathrm{D}_{2}$ IN CALCIUM. Fukuda K. , Ueda K., J. Phys. Chem. 86, 676.

3826. COLLISION BROADENING AND SHIFTS IN THE SPECTRA OF NEUTRAL AND SINGLY IONIZED MAGNESIUM, CALCIUM AND STRONTIUM. Giles R. G., Lewis E. L., J. Phys. B 15, 2871 (1982). 
3827. OBSERVATION OF COLLISIONAL NARROWING IN A TWO-PHOTON TRANSITION IN A THREE-LEVEL SYSTEM. Glab W., Hillard G. B., Nayfeh M. H., Phys. Rev. A 25,3431 .

3828. STARK-WIDTH MEASUREMENTS OF NEUTRAL AND SINGLY IONIZED MAGNESIUM RESONANCE LINES IN A WALL-STABILIZED ARC. Goldbach Cl., Nollez G., Plomdeur P., Zimmermann J. P., Phys. Rev. A 25, 2596.

3829. EXPERIMENTAL STARK WIDTHS AND SHIFTS OF TWO ULTRAVIOLET C II LINES. Goly A., Weniger S., J. Quant. Spectrosc. Radiat. Transfer 27, 657.

3830. STARK WIDTHS AND TRANSITION PROBABILITIES OF SOME MULTIPLETS ON SINGLY IONIZED CARBON. Goly A., Weniger S., J. Quant. Spectrosc. Radiat. Transfer 28,389 .

3831. COLLISIONS OF RYDBERG ATOMS: RECENT ADVANCES. Gounand F., J. Phys. (Paris), Colloq. C2 43, 291.

3832. INFLUENCE OF INELASTIC COLLISIONS ON THE WIDTH OF OPTICAL LINES INVOLVING RYDBERG STATES. Gounand F., Szudy J., Hugon M., Sayer B., Fournier P. R., Phys. Rev. A 26, 831 .

3833. COMMENTS ON THE REQUIREMENTS FOR A GENERAL STARK BROADENING THEORY. Greene R. L., J. Quant. Spectrosc. Radiat. Transfer 27, 185.

3834. A RELAXATION THEORY OF STARK BROADENING BY IONS. Greene R. L., J. Quant. Spectrosc. Radiat. Transfer, 27, 639.

3835. ION-RADIATOR DYNAMIC EFFECTS IN STARK BROADENING OF He II LINES. Greene R. L., J. Phys. B 15, 1831.

3836. BROADENING OF THE LYMAN- $\beta$ LINE OF HYDROGEN BY LOW-FREQUENCY FIELDS IN DENSE PLASMAS. Griem H. R., Tsakiris G. D., Phys. Rev. A 25, 1199.

3837. AUTOMATIC ANALYSIS OF A VOIGT PROFILE OR LINEAR COMBINATION OF SEVERAL VOIGT PROFILES. Guilpin C., Mangeot B., J. Phys. D 15, 537.(Fr.)

3838. EMPIRICAL INTERATOMIC POTENTIALS FOR Ba-RARE-GAS SYSTEMS DEDUCED FROM AN ABSORPTION MEASUREMENT. Harima H., Tachibana K., Urano Y., J. Phys. B 15,3679 . 
3839. THE SHIFT OF THE ATOMIC RESONANCE LINES OF LITHIUM BY NOBLE GASES. Harris M. , Lwin N., McGartan D. G., J. Phys. B 15, L831.

3840. STARK SHIFTS OF IONIZED HELIUM LINES. Hashimoto S., J. Phys. Soc. Jpn. $51,1613$.

3841. A NEW FORMULA FOR THE SPECTRAL LINE BROADENING IN PLASMAS WITH APPLICATION TO THE ASYMMETRY OF Ly- $\alpha$. Hegerfeldt G. C., Reibold R., Z. Naturforsch., Teil A 37, 305.

3842. QUANTUM DIFFRACTION CORRECTIONS TO THE HIGH-FREQUENCY THERMAL MICROFIELD IN A DENSE Plasma. Held B., Deutsch G., Gombert M. M., Phys. Rev. A 25, 585 .

3843. QUANTUM CORRECTIONS TO THE HIGH-FREQUENCY THERMAL MICROFIELD IN A DENSE PLASMA. Held B., Deutsch C., Gombert M. M., J. Phys. A 15, 3845.

3844. A CLASSICAL PATH CALGULATION OF STARK BROADENING OF ISOLATED ION LINES BY PLASMAS. Hey J. D., Breger P., S. Afr. J. Phys. 5, 111.

3845. THE SHAPE OF SPECTRAL LINES WITH COMBINED IMPACT AND STATISTICAL BROADENINGS. Hirono M., Nakazawa T., J. Phys. Soc. Jpn. 51, 265.

3846. COLLISION BROADENING AND SHIFT OF THE POTASSIUM 4p-ns AND 4p-nd LINES BY ARGON. Hohimer J. P., Gee J., Phys. Rev. A 25, 1404.

3847. OPTIMIZED COMPUTATION OF THE VOIGT AND COMPLEX PROBABILITY FUNCTIONS. .Humlicek J., J. Quant. Spectrosc. Radiat. Transfer 27, 437.

3848. HIGH ORDER ASYMPTOTIC EXPANSIONS OF THE FOUR KERNEL FUNCTIONS FOR LINE FORMATION WITH THE VOIGT PROFILE. Hummer D. G., J. Quant. Spectrosc. Radiat. Transfer 27, 569.

3849. CLUSTER EXPANSION FOR THE ELECTRIC MICROFIELD DISTRIBUTION IN A PLASMA. Iglesias C. A., Hooper Jr. C. F., Phys. Rev. A 25, 1049.

3850. QUANTUM CORRECTIONS TO THE LOW-FREQUENCY-COMPONENT MICROFIELD DISTRIBUTIONS. Iglesias C. A., Hooper Jr. C. F., Phys. Rev. A 25, 1632.

3851. SHIFT OF ${ }^{2} \mathrm{~S}_{1 / 2}$ HYPERFINE SPLITTINGS DUE TO BLACKBODY RADIATION. Itano $W$. M., Lewis L. L., Wineland D. J., Phys. Rev. A 25, 1233. 
3852. ROLE OF RADIATIVE TRANSFER IN SPECTRAL LINE SHAPES FROM PLASMAS. Jamelot G., Jaeglé P., Carillon A., Ann. Phys. (Paris) 7, 399.

3853. PARAMETERS OF A LASER PRODUCED PLASMA FROM XUV LINE PROFILES. Jannitti E., Nicolosi P., Tondello G., J. Phys. (Paris) 43, 1043.

3854. NONADIABATIC THEORY OF COLLISION-BROADENED ATOMIC LINE PROFILES. Julienne P. S., Phys. Rev. A 26, 3299.

3855. RELATIVE NOBLE-GAS-INDUCED BROADENING OF THE D LINES OF ATOMIC LITHIUM. Kachru R., Chen T. J., Mossberg T. W., Hartmann S. R., Phys. Rev. A 25 , 1546 .

3856. CALCULATIONS OF LINE ABSORPTION OF SPECIFIC HELIUM LINES FOR THE VOIGT PROFILE. Kato I., Yonehara A., J. Opt. Soc. Am. 72, 395.

3857. A COMMENT ON THE REDUCIBILITY OF THE VOIGT FUnCTIONS. Katriel J., J. Phys. A 15, 709 .

3858. POSITION AND WIDTH OF THE RESONANCE IN ELECTRON-POTASSIUM SCATTERING FROM SELF-BROADENING OF RYDBERG STATES. Kaulakys B., J. Phys. B 15, L719.

3859. INTERFEROMETRIC MEASUREMENTS OF SPECTRAL LINE WIDTHS EMITTED BY AN INDUCTIVELY COUPLED PLASMA. Kawaguchi H., Oshio Y., Mizuike A., Spectrochim. Acta, Part B 37, 809.

3860. STARK-PROFILE CALCULATIONS FOR THE C VI LINE $n=7$ to 6 AT $3434 \AA$ FROM DENSE Plasmas. Kepple P. C., Griem H. R., Phys. Rev. A 26, 484.

3861. THE RELATIVISTIC DOPPLER BROADENING OF THE LINE ABSORPTION PROFILE. Kichenassamy S., Krikorian R., Nikoghossian A., J. Quant. Spectrosc. Radiat. Transfer 27, 653.

3862. THE EFFECT OF RARE-GAS COLLISIONS ON THE WINGS OF THE POTASSIUM $4 \mathrm{p}{ }^{2} \mathrm{P}_{3 / 2}$ - $7 \mathrm{~s}^{2} \mathrm{~S}_{1 / 2}(5802 \AA)$ TRANSITION. Kielkopf J. F., J. Phys. B 15, 915.

3863. OBSERVATION OF EFFECT OF STIMULATED PROCESSES ON DRESSED-STATE COLLISIONAL·KINETICS. Kleiber P. D., Burnett K., Cooper J., Phys. Rev. A 25,1188 . 
3864. BROADENING OF THE $6328 \AA$ Ne LINE FOR DIFFERENT VELOCITIES OF THE COLLIDING PARTICLES. Kotlikov E. N., Tokarev V. I., Opt. Spectrosc. (USSR) 53, 360 .

3865. ELECTRON DENSITY MEASUREMENTS IN A LASER INDUCED Na PLASMA. Krebs D. J., Schearer L. D., J. Chem. Phys. 76, 2925.

3866. RARE-GAS, COLLISION-INDUCED SHIFTS OF THE nD STATES OF SODIUM. Krebs D. J., Schearer L. D., Phys. Rev. A 26, 1473.

3867. TEMPERATURE DEPENDENCE OF THE SHIFT, WIDTH AND ASYMMETRY OF THE POTASSIUM (4p-7s) $5802 \AA$ LINE PERTURBED BY ARGON. Kreye W. C., J. Phys. B 15, 371.

3868. DETERMINATION OF ELECTRON TEMPERATURE FROM THE ABSOLUTE INTENSITIES OF SPECTRAL LINES IN A NONEQUILIBRIUM PLASMA. Kudryavtsev A. A., Skrebov V. N., Opt. Spectrosc. (USSR) 52, 370.

3869. EXPERIMENTAL STARK BROADENING DATA OF Si II AND Si III LINES. Kusch H. J., Schröder K., Astron. Astrophys. 116, 255.

3870. COLLISION EFFECTS IN RYDBERG STATES OF XENON. Labastie P., Giacobino E., Biraben F., J.'Phys. B 15, 2605.

3871. STARK WIDTH AND SHIFT OF Cs I 852.11 nm RESONANCE LINE. Lakicevic I. S., Puric J., Cuk M., Phys. Lett. A 91, 19.

3872. COMMENTS ON THE CALCULATION OF SPECTRAL LINE SHIFTS INDUCED BY PLASMA PERTURBATIONS. Lee R. W., J. Quant. Spectrosc. Radiat. Transfer 27, 249.

3873. THE EFFECTS OF GRADIENTS ON THE DIAGNOSTIC USE OF SPECTRAL FEATURES FROM LASER COMPRESSED PLASMAS. Lee R. W., J. Quant. Spectrosc. Radiat. Transfer 27,87 .

3874. NOBLE-GAS INDUCED COLLISIONAL BROADENING OF THE $6 \mathrm{P}_{1 / 2}-6 \mathrm{P}_{3 / 2}$ TRANSITION OF T1 MEASURED BY RAMAN ECHOES. Leung K. P., Mossberg T. W., Hartmann S. R., Phỳs. Rev. A 25, 3097.

3875. BROADENING AND SHIFT OF THE $535.0 \mathrm{~nm}$ THALLIUM LINE BY NITROGEN. Lisicki E., Bielski A., Szudy J., Z. Naturforsch A, Teil A 37, 93. 
3876. PRESSURE EFFECTS OF $\mathrm{CO}_{2}$ ON THE $535 \mathrm{~nm}$ Tl LINE ACCOMPANYING THE PHOTODISSOCIATION OF Tl I. Lisicki E., Bielski A., Dygdala R. S., Szudy J., Acta Phys. Pol. A 61, 421.

3877. HIGHER ORDER STIMULATED RADIATIVE CORRECTIONS IN HYDROGEN. Maquet A., J. Phys. (Paris), Colloq. C2 43, 451.

3878. IMPROVED OVERLAPPING HELIUM LINE PROFILES FOR STELLAR SPECTRA STUDIES. Mazure A., Nollez G., Astrophys. J. 254, 823.

3879. EXPERIMENTAL STARK WIDTHS OF Xe II AND TRENDS IN THE BROADENING OF HOMOLOGOUS RARE-GAS IONS. Miller M. H., Lesage A., Abadie D., Phys. Rev. A 25,2064 .

3880. ELECTRON NUMBER DENSITY MEASUREMENTS IN Ar AND Ar- ${ }_{2}$ INDUCTIVELY COUPLED PLASMAS. Montaser A., Fassel V. A., Appl. Spectrosc. 36, 613.

3881. COLLISIONAL BROADENING OF SPECTRAL LINE SHAPES IN TWO-PHOTON AND MULTIPHOTON PROCESSES. Mukamel S., Phys. Rep. 93, 1.

3882. ON THE DENSITY EXPANSION OF SPECTRAL LINESHAPES. Mukamel S., Grimbert D., Opt. Commun. 40, 421.

3883. POSSIBILITY OF USING THE STIMULATED LIGHT ECHO METHOD TO SEPARATE THE CONTRIBUTIONS MADE BY DIFFERENT MECHANISMS OF SPECTRAL LINE BROADENING TO RELAXATION IN GASES. Nefedev L. A., Opt. Spectrosc. (USSR) 52, 590.

3884. BROADENING OF SPECTRAL LINES IN LASER PLASMAS: THE CASE OF THE LINES OF LITHIUMLIKE ALUMINUM. Nguyen Hoe, Leboucher E., Grumberg J., Coulaud G., Ann. Phys. (Paris) 7, 447.(Fr.)

3885. LASER SPECTROSCOPY With THE THERMionic DiOde. Niemax K., Acta Phys. Pol. A $61,517$.

3886. COLLISIONS IN A RADIATION FIELD AND THE SPECTRA OF DRIVEN ATOMS. Nienhuis G., Acta Phys. Pol. A 61, 235.

3887. ATOMIC LINE BROADENING IN PLASMA WITHIN A WIDE RANGE OF LASER FREQUENCIES. Pargamanik L. E., Ukr. Fiz. Zh. 27, 450.(Russ.) 
3888. A METHOD OF FORWARD SCATTERING IN THE THEORY OF HYDROGEN LINE BROADENING IN PLASMA. Pargamanik L. E., Ukr. Fiz. Zh. 27, 1426.(Russ.)

3889. QUASICLASSICAL THEORY FOR WINGS OF HYDROGEN SPECTRAL LINES. Pargamanik L. E., Ginzburg M. D., Sov. J. Plasma Phys. 8, 428.

3890. EXPERIMENTAL STUDY OF THE SHAPE OF THE 253,7 nm MERCURY LINE PERTURBED BY LIGHT NOBLE GASES (He, Ne). Perrin D., Ben Lakhdar Z., Jeannet J. C., Lennuier R., J. Phys. (Paris) 43, 45.(Fr.)

3891. DEPENDENCE OF LINE SHAPE ON POLARIZATION IN COLLISIONS IN BEAMS. TRANSITION BETWEEN DEGENERATE ELECTRONIC STATES $j=1-j_{0}=1$. Petrashen A. G., Rebane V. N., Rebane T. K., Opt. Spectrosc. (USSR) 53, 589.

3892. EFFECT OF LIGHT SHIFTS IN A VELOCITY-SELECTIVE OPTICAL PUMPING EXPERIMENT. Pinard M., Aminoff C. G., J. Phys. (Paris) 43, 1327.(Fr.)

3893. PERIODIC DEPENDENCE OF STARK WIDTH AND SHIFT ON NUCLEAR CHARGE NUMBER. Puric J., Lakicevic I. S., Phys. Lett. A 91, 345.

3894. NONIMPACT THEORY OF ABSORPTION LINE BROADENING IN STRONG RADIATION FIELDS. Rabin Y., Grimbert D., Mukame1 S., Phys. Rev. A 26, 271.

3895. ON THE SELF-SHIFT AND BROADENING OF DOPPLER-FREE RYDBERG ${ }^{2} \mathrm{~S}$ SPECTRAL LINES IN ALKALI ATOMS. Rabin Y., Rebentrost F., Opt. Commun. 40, 257.

3896. MANY-BODY STUDY OF VAN DER WAALS. INTERACTION INVOLVING LITHIUM AND RARE-GAS ATOMS AND ITS CONTRIBUTION TO HYPERFINE SHIFTS. Rao B. K., Das T. P., Pramana 19, 289.

3897. BROADENING OF NONLINEAR SPECTRAL RESONANCES WHEN IONS INTERACT VIA PLASMA WAVES. Rautian S. G., Smirnov G. I., Shapiro D. A., Sov. Phys.--Dok1. 27, 75.

3898. COMPENSATION OF DOPPLER BROADENING BY LIGHT SHIFTS IN TWO PHOTON ABSORPTION. Reynaud S., Himbert M., Dalibard J., Dupont-Roc J., Cohen-Tannoudji C., Opt. Commun. 42, 39.

3899. BROADENING OF HYPERFINE COMPONENTS OF Na D LINES PERTURBED BY He. Roueff E., Spielfiedel A., J. Phys. B 15, 2627; 16, 505 (1983). 
3900. MEASUREMENT OF THE STARK BROADENING OF THE PASCHEN BETA LINE OF HYDROGEN IN A LINEAR DISCHARGE. Sanchez A., Maldelbaum D., Castell R., Rev. Bras. Fis. (Vol. Espec. 1), 57-63 (1982).

3901. RESOLUTION BEYOND NATURAL LINEWIDTH VIA FLUORESCENCE IN MODULATED BEAMS. Saxena R., Agarwal G. S., Opt. Commun. 40, 357.

3902. DETERMINING INTERATOMIC POTENTIALS FROM LINE SHAPE STUDIES. Sayer B., Acta Phys. Pol. A 61, 531.

3903. ON QUANTUM-MECHANICAL UNIFIED THEORIES OF COLLISIONAL SPECTRAL LINE BROADENING. Schuller F., Nienhuis G., J. Quant. Spectrosc. Radiat. Transfer 28, 355 .

3904. EFFECTS OF RADIATOR MOTION ON PLASMA-BROADENED HYDROGEN LYMAN- $\beta$. Seidel J., Stamm R., J. Quant. Spectrosc. Radiat. Transfer 27, 499.

3905. POSSIBILITY OF DETERMINING SPECTRAL PARAMETERS IN THE CASE OF AN UNKNOWN INSTRUMENTAL FUNCTION. Sheremeteva T. A., Borisova N. F., Opt. Spectrosc. (USSR) 52, 220 .

3906. SHIFTS OF Ar II EMISSION LINES IN A DENSE PLASMA. Simard P. A., Can. J. Phys. 60, 820.(Fr.)

3907. HIGH-RESOLUTION SPECTROSCOPY AND COLLISION STUDIES OF HIGH-LYING ATOMIC STATES USING FOUR-WAVE MIXING. Steel D. G., Lam J. F., McFarlane R. A., Phys. Rev. A 26, 1146.

3908. PRESSURE BROADENING AND SHIFT OF SPECTRAL LINES. Szudy J., Postepy Fiz. 33, 231. ( Pol.)

3909. MEASUREMENTS OF COLLISIONAL BROADENING AND THE SHIFT OF ARGON SPECTRAL LINES USING A TUNABLE DIODE LASER. Tachibana K., Harima H., Urano Y., J. Phys. B 15, 3169.

3910. LIGHT SHIFTS IN QUANTUM-BEAT SPECTROSCOPY. Taiqian D., Metcalf H., Phys. Rev. A 25, 3435 .

3911. MODEL MICROFIELD THEORY OF REDISTRIBUTION OF LASER RADIATION. Talin B., Klein L., Phys. Rev. A 26, 2717. 
3912. PROFILE: A CODE FOR EVALUATING LINE PROFILE SHAPES FOR OPTICALLY THICK EXPANDING PLASMAS. Tallents G. J., Comput. Phys. Commun. 25, 141.

3913. AN INSTRUMENTAL EFFECT ON SPECTRAL LINE PROFILES. Thompson R. C., J. Quant. Spectrosc. Radiat. Transfer 27, 417.

3914. PLASMA SATELLITES IN THE PRESENCE OF A NON-COHERENT AND UNPOLARIZED RADIATION FIELD. Truong-Bach, Drawin H. W., J. Quant. Spectrosc. Radiat. Transfer 27,627 .

3915. RECONSTRUCTION OF A SPECTRAL PROFILE ALLOWING FOR DATA ON THE RESIDUAL INSTRUMENTAL FUNCTION. Tsoi V. I., Velichko A. G., Opt. Spectrosc. (USSR) 52,632 .

3916. ABSORPTION STUDIES OF THE COLLISION-INDUCED-DIPOLE TRANSITION ASSOCIATED WITH THE $4 \mathrm{~s}^{2}{ }^{1} \mathrm{~s}_{0}-4 \mathrm{~s} 3 \mathrm{~d} \cdot{ }^{1} \mathrm{D}_{2}$ TRANSITION IN CALCIUM IN THE PRESENCE OF RARE GASES. Ueda K., Fukuda K., J. Phys. Chem. 86, 678.

3917. COLLISION BROADENING OF PRINCIPAL SERIES LINES OF CALCIUM IN THE PRESENCE OF KRYPTON. Ueda K., Hamaguchi. Y., Fukuda K., J. Phys. Soc. Jpn. 51, 13.

3918. COLLISION BROADENING OF PRINCIPAL SERIES LINES OF CALCIUM IN THE PRESENCE OF HELIUM. Ueda K., Hamaguchi Y., Fukuda K., J. Phys. Soc. Jpn. 51, 612.

3919. RARE-GAS-INDUCED BROADENING OF Ca PRINCIPAL SERIES LINES. Ueda K., Hamaguchi Y., Fukuda K., J. Phys. Soc. Jpn. 51, 1948.

3920. POWER BROADENING OF THE Na-D LINES IN A FLAME - II. THE FLUORESCENCE LINE WIDTH AS A FUNCTION OF THE SPECTRAL IRRADIANCE OF THE PULSED DYE LASER. Van Calcar R. A., Heuts M. J. G., Van Uitert B. K., Meijer H. A. J., Hollander T. J., Alkemade C. Th. J., J. Quant. Spectrosc. Radiat. Transfer $28,1$.

3921. ON HYPERFINE FREQUENCY SHIFTS GAUSED BY BUFFER GASES: APPLICATION TO THE OPTICALLY PUMPED PASSIVE RUBIDIUM FREQUENCY STANDARD. Vanier J., Kunski R., Cyr N., Savard J. Y., Tetu M., J. Appl. Phys. 53, 5387.

3922. ON THE LIGHT SHIFT IN OPTICAL PUMPING OF RUBIDIUM 87: THE TECHNIQUES OF "SEPARATED" AND "INTEGRATED" HYPERFINE FILTERING. Vanier J., Kunski R., Paulin P., Tetu M., Cyr N., Can. J. Phys. 60, 1396. 
3923. DETERMINATION OF THE TEMPERATURE DISTRIBUTION IN A HOT GAS STREAM FROM THE PROFILE OF A SELF-REVERSED SPECTRAL LINE. Vasil'eva I. A., Gendzhov S., Orlov A. V., Stefanov B., Urinson A. S., Sov. Phys.--Dokl. 27, 494.

3924. INERT-GAS BROADENING OF THE THALLIUM MI-TRANSITION ABSORPTION LINE. Vasilevskii K. P., Kotylev V. N., Kulyasov V. N., Opt. Spectrosc. (USSR) $52,94$.

3925. TRIPLET SATELLITE BAND IN THE VERY FAR BLUE WING OF THE SELF-BROADENED LithiUM RESONANCE LINE. Veza D., Milosevic S., Pichler G., Chem. Phys. Lett. 93,401 .

3926. RARE GAS COLLISIONAL PERTURBATION OF THE $\left(6{ }^{3} \mathrm{D}_{1}, 6{ }^{1} \mathrm{D}_{2}\right)$ LEVELS OF MERCURY: A THEORETICAL ESTIMATE II. Vienne-Casalta D., Margerie J., J. Phys. (Paris) 43, 31.

3927. MULTIATOM COHERENCE IN THE REDISTRIBUTION OF RADIATION. Voslamber D., J. Phys. B 15, L789; 16, 1669 (1983).

3928. EXPONENTIALLY DECREASING COLLISION-BROADENED LINE SHAPES. Walkup R. E., Phys. Rev. A 25, 596.

3929. IMPACT BROADENING AND SHIFT OF Rb nS AND nD LEVELS BY NOBLE GASES. Weber K. H., Niemax K., Z. Phys. A 307, 13.

3930. IMPACT BROADENING OF Sr 5 sns ${ }^{1} S_{0}$, 5 snd ${ }^{1} D_{2}$ AND 5 snd ${ }^{3} D_{2}$ LEVELS BY He AND Xe. Weber K. H., Niemax K., Z. Phys. A 309, 19.

3931. SPECTRUM DIAGNOSTICS. THE NECESSITY FOR DETAILED NON-LTE MODELING OF X-RAY EMISSION FROM DENSE PLASMAS. Whitney K. G., Kepple P. C., J. Quant. Spectrosc. Radiat. Transfer 27, 281.

3932. REGULARITIES AND SIMILARITIES IN PLASMA BROADENED SPECTRAL LINE WIDTHS (STARK WIDTHS). Wiese W. L., Konjevic N., J. Quant. Spectrosc. Radiat. Transfer 28, 185 .

3933. $7^{2} \mathrm{D}_{3 / 2}-7^{2} \mathrm{D}_{5 / 2}$ EXCITATION TRANSFER IN RUBIDIUM INDUCED IN COLLISIONS WITH GROUND-STATE Rb AND NOBLE-GAS ATOMS. Wolnikowski J., Atkinson J. B., Supronowicz J., Krause L., Phys. Rev. A 25, 2622. 
3934. STARK BROADENING IN HOT, DENSE, LASER-PRODUCED PLASMAS: A REVIEW. Woltz L. A., Iglesias C. A., Hooper Jr. C. F., J. Quant. Spectrosc. Radiat. Transfer 27, 233.

3935. ABSORPTION OF POWERFUL RESONANCE RADIATION ACCOMPANYING COLLISIONAL LINE BROADENING. Yakovlenko S. I., Sov. Phys.--Usp. 25, 216.

3936. AMPLITUDE PHASE METHOD FOR THE DETERMINATION OF AN ABSORPTION CROSS SECTION IN SPECTRAL LINE WINGS. Zhuvikin G. V., Shabanova L. N., Vestn. Leningr. Univ., Fiz. Khim. 22, No. 4, 21.(Russ.)

3937. BROADENING OF C IV LINES IN DENSE PLASMAS. Ackermann U., Finken K. H., Musielok J., "Proceedings of the Sixteenth Int. Conf. on Phenomena in Ionized Gases, Vo1. 4, Contributed Papers," 620-621 (Eds. W. Butticher, H. Wenk \& E. Schulz-Gulde, Organ. Comm. ICPIG XVI, Dusseldorf, WG, 1983).

3938. PLASMA SHIFTS OF THE LYMAN LINES TO SHORTER WAVELENGTHS IN C VI. Adcock J. C. Jr., Griem H. R., Phys. Rev. Lett. 50, 1369; 53, 510 (1984).

3939. POLARIZATION OF COLLISIONALLY REDISTRIBUTED LIGHT FROM THE FAR WINGS OF STRONTIUM-RARE-GAS SYSTEMS. Alford W. J., Burnett K., Cooper J., Phys. Rev. A 27, 1310.

3940. EFFECT OF THE DIFFERENT PARTS OF THE INTERACTION POTENTIAL-ON THE LINE PROFILE IN NEUTRAL ATOM-ATOM COLLISIONS. Allard N. F., Biraud Y. G., J. Phys. (Paris) 44, 935.

3941. COLLISION EFFECTS IN VELOCITY-SELECTIVE OPTICAL PUMPING OF SODIUM. Aminoff G. G., Javanainen J., Kaivola M., Phys. Rev. A 28, 722.

3942. STIMULATED RADIATIVE CORRECTIONS .IN HYDROGEN IN THE PRESENCE OF A STRONG LASER FIELD. Arnous E., Bastian J., Maquet A., Phys. Rev. A 27, 977.

3943. DETERMINATION OF THE PERTURBATION AND CALGULATION OF THE PROFILE OF THE SEMIDEGENERATE $4 \mathrm{f} 4 \mathrm{~d} 4 \mathrm{p}$ - 2p LITHIUM Li I LINE EMITTED BY AN ELECTROLYTIC PLASMA TAKING INTO ACCOUNT THE ION DYNAMIC EFFECT. Bardet J. P., Valognes J. C., J. Phys. (Paris) 44, 797.(Fr.) 
3944. TIME DEPENDENCE OF ABSORPTION LINESHAPES. Bassani F., Quattropani A., Girlanda R., Phys. Lett. A 97, 150.

3945. STARK EFFECT ON ISOLATED LINES OF Mg II AND Ca II IN A D.C.-ARC PLASMA WITHOUT AND WITH Cs. Bassyouni A. H., Ramadan A. G., Egypt. J. Phys. 14, 101.

3946. APPLICATION OF EXCHANGE PERTURBATION THEORIES TO CALCULATING COLLISIONAL HYPERFINE LINE SHIFTS FOR HYDROGEN ATOMS IN HELIUM. Batygin V. V., Bukhvalov A. V., Sokolov I. M., Sov. Phys.--Tech. Phys. 28, 881.

3947. COLLISIONAL SHIFT AND ADIABATIC BROADENING OF GROUND STATE HYPERFINE TRANSITION LINES OF THALLIUM IN BUFFER ATMOSPHERES OF HELIUM, KRYPTON, AND XENON. Batygin V. V., Sokolov I. M., Opt. Spectrosc. (USSR) 55, 16.

3948. BLACK-BODY RADIATION SHIFTS IN GROUND AND METASTABLE LEVELS OF Mg AND Ca. Bava E., De Marchi A., Godone A., Lett. Nuovo Cimento C 38, 107.

3949. THE THEORY OF INTERATOMIC POTENTIALS FOR LINE BROADENING. Baylis W. E., "Spectral Line Shapes," Vol. 2, 409-428 (Ed. K. Burnett, Walter de Gruyter \& Co., New York, 1983).

3950. AN EXPERIMENTAL STUDY OF ION DYNAMIC EFFECTS ON HELIUM LINE PROFILES. Bengtson R. D., Pease D. C., "Spectral Line Shapes," Vol. 2, 183-197 (Ed. K. Burnett, Walter de Gruyter \& Co., New York, 1983).

3951. A FAST DETERMINATION OF THE WIDTH OF A LORENTZIAN PROFILE WITH SHOT NOISE. Berard M., J. Phys. E 16, 283.

3952. STUDY OF PLASMA TURBULENCE IN A FAST LINEAR THETA-PINCH BY MEANS OF STARK BROADENING OF DEUTERIUM SPECTRAL LINES. Berezin A. B., Lyublin B. V., Yakovlev D. G., Sov. Phys.--Tech. Phys. 28, 407.

3953. LOW PRESSURE BROADENING AND SHIFT OF THE $632.8 \mathrm{~nm}$ NEON SPECTRAL LINE. Bielski A., Bobkowski R., Dygdala R., Wawrzynski J., Acta Phys. Pol. A 63,411 .

3954. LOW PRESSURE SHIFT OF THE $2 p^{5} 3 p-2 p^{5} 5 s$ SPECTRAL LINES OF NEON PERTURBED BY NEON AND HELIUM. Bielski A., Bobkowski R., Dygdala R., Wawrzynski J., Physica C (Amsterdam) 115, 261. 
3955. UNIVERSAL STATIONARY-PHASE TREATMENT OF FAR-WING AND EXCIMER SPECTRAL LINE SHAPES. Bieniek R. J., Streeter T. J., Phys. Rev. A 28, 3328.

3956. MICROFIELD DISTRIBUTION FOR DEGENERATE ELECTRONS. Boercker D. B., Dufty J. W., "Spectral Line Shapes," Vol. 2, 265-279 (Ed. K. Burnett, Walter de Gruyter \& Co., New York, 1983).

3957. STRONG COUPLING EFFECTS ON PLASMA LINESHAPES AND THOMSON SCATTERING SIGNALS. Boercker D. B., Lee R. W., Rogers F. J., J. Phys. B 16, 3279.

3958. DETERMINATION OF THE EMISSION CROSS SECTION FOR THE ${ }^{2} \mathrm{P}_{1 / 2}-{ }^{2} \mathrm{P}_{3 / 2}$ TRANSITION OF THE BROMINE ATOM. Boriev I. A., Gordon E. B., Nadkhin A. I., Sotnichenko S. A., Opt. Spectrosc. (USSR) 54, 233.

3959. SPECTRAL LINE SHAPES FROM TWO PHOTON EXCITATION OF XENON. Böwering N., Kuo C.-Y., Raymond T. D., Keto J. W., "Spectral Line Shapes," Vol. 2, 927-943 (Ed. K. Burnett, Walter de Gruyter \& Co., New York, 1983).

3960. STUDY OF THE $1750 \AA$ MERCURY ABSORPTION BAND. DETERMINATION OF THE EXCITED INTERACTION POTENTIAL AND OF THE OSCILLATOR STRENGTH RELATED TO THIS BAND. Bras N., Bousquet C., J. Phys. B 16, 3383.

3961. IONIZATION DETECTION OF RYDBERG LINESHAPES IN STRONTIUM VAPOR PERTURBED BY.FOREIGN GASES. Bruce D. M., Duley W. W., J. Phys. (Paris), Colloq C7, Supp1. 11, 44, 469 .

3962. COMPARISON OF PRESSURE SHIFT IMPACT CALCULATIONS WITH EXPERIMENTAL RESULTS. Buffa G., Tarrini O., J. Mol. Spectrosc. 101, 271.

3963. INHOMOGENEOUS LIGHT SHIFT IN ALKALI-METAL ATOMS. Camparo J. C., Frueholz R. P., Volk C. H., Phys. Rev. A 27, 1914.

3964. STARK BROADENING OF THE PASCHEN-BETA LINE OF HYDROGEN IN A LINEAR DISCHARGE. Castell R., Mandelbaum D., Mendez A., Sanchez A., J. Quant. Spectrosc. Radiat. Transfer 30, 345.

3965. BROADENING OF LYMAN LINES OF HYDROGEN AND HYDROGENIC IONS BY LOW-FREQUENCY FIELDS IN DENSE PLASMAS. Cauble R., Griem H. R., Phys. Rev. A 27, 3187. 
3966. BROADENING OF LYMAN- $\alpha$ AND $\gamma$ OF HYDROGENIC IONS BY LOW-FREQUENCY FIELDS IN DENSE PlaSMAS. Cauble R., Griem H. R., "Spectral Line Shapes," Vo1. 2, 281-290 (Ed. K. Burnett, Walter de Gruyter \& Co., New York, 1983).

3967. COLLISIONAL BROADENING OF NONLINEAR OPTICAL RESONANCES. Chebotayev $\mathrm{V}$. P., Vasilenko L. S., Prog. Quantum Electron. 8, 79.

3968. ON THE LINE PROFILE COEFFICIENT FOR STIMULATED EMISSION. Cooper J., Hubeny I., Oxenius J., Astron. Astrophys. 127, 224.

3969. EXPERIMENTAL STUDY OF STARK BROADENING OF THE ARGON I $430.01 \mathrm{~nm}$ LINE. Czernichowski A., Chapelle J., Acta Phys. Pol. A 63, 67.(Fr.)

3970. EFFECT OF MODULATED HIGH-PRESSURE MERCURY DISCHARGES ON THE SHAPE OF SELF-REVERSED LINES. Damelincourt J. J., Aubes M., Fragnac P., Karabourniotis D., J. Appl. Phys. 54, 3087.

3971. QUASISTATIC WING AND BLUE SATELLITE OF THE 4s-5p DOUBLET OF POTASSIUM, PERTURBED BY NEON. Delhoume M., Brillet W.-Ü L., Masnou-Seeuws F., Feautrier N., Rostas F., Ann. Phys. (Paris) 8, 225.(Fr.)

3972. HOLTZMARK ELECTRIC FIELD DISTRIBUTION IN A TWO-DIMENSIONAL ELECTRON FLUID. Deutsch C., Phys. Lett. A 94, 40.

3973. INFLUENCE OF DIFFERENT COLLISIONAL PROCESSES ON THE STARK BROADENING. Dimitrijevic M. S., Feautrier N., Sahal-Bréchot S., Fizika (Zagreb) 15, 205.

3974. STARK BROADENING OF ISOLATED SPECTRAL LINES OF HEAVY ELEMENTS IN PLASMAS. Dimitrijevic M. S., Konjevic N., J. Quant. Spectrosc. Radiat. Transfer $30,45$.

3975. STARK BROADENING OF Si II AND Si III SPECTRAL LINES. Dimitrijevic M. S., Astron. Astrophys. 127, 68 .

3976. SEMICLASSICAL CALCULATION OF He I STARK BROADENING PARAMETERS. Dimitrijevic M. S., Sahal-Bréchot S., "Proceedings of the Sixteenth Int. Conf. on Phenomena in Ionized Gases, Vol. 4, Contributed Papers, " 630-631 (Eds. W. Butticher, H. Wenk \& E. Schulz-Gulde, Organ. Comm. ICPIG XVI, Dusseldorf, WG, 1983). 
3977. APPROXIMATE ELECTRON- AND PHOTON-IMPACT LINE WIDTHS WITHIN A SPECTRAL SERIES. Dimitrijevic M. S., Sahal-Bréchot S., "Proceedings of the Sixteenth Int. Conf. on Phenomena in Ionized Gases, Vol. 4, Contributed Papers," 628-629 (Eds. W. Butticher, H. Wenk \& E. Schulz-Gulde, Organ. Comm. ICPIG XVI, Dusseldorf, WG, 1983).

3978. STARK BROADENING PARAMETERS FOR He I INFRARED LINES. Dimitrijevic M. S., Sahal-Brechot S., "Spectral Line Shapes," Vol. 2, 103-115 (Ed. K. Burnett, Walter de Gruyter \& Co., New York, 1983).

3979. MEASUREMENTS OF THE SHIFT AND WIDTH OF THE NEON $633 \mathrm{~nm}$ LINE BY THE METHOD OF NONLINEAR ABSORPTION DURING MAGNETIC SCANNING. Dmitrieva I. V., Kondrateva V. A., Kotlikov E. N., Tokarev V. I., Khvostov A. N., Opt. Spectrosc. (USSR) 54, 358 .

3980. CO LASER ENHANCEMENT OF THE ELECTRON COLLISIONAL BROADENING OF THE 4713 $\AA$ LINE IN A LOW PRESSURE He PLASMA. Dubreuil B., Pignolet P., "Proceedings of the Sixteenth Int. Conf. on Phenomena in Ionized Gases, Vo1. 4, Contributed Papers," 636-637 (Eds. W. Butticher, H. Wenk \& E. Schulz-Gulde, Organ. Comm. ICPIG XVI, Dusseldorf, WG, 1983).

3981. SELF-REVERSED LINE PROFILES BY SCANNING LASER EXCITATION. Eicher C. A., Allen L., Phys. Lett. A 93, 119.

3982. STARK BROADENING OF LINES FROM MULTIPLY-CHARGED CARBON IONS IN A HIGH-DENSITY ARC PLASMA. E1-Farra M. A., Hugues T. P., J. Quant. Spectrosc. Radiat. Transfer, 30, 335.

3983. TRANSITION PROBABILITY AND COLLISION BROADENING OF THE $1.3 \mu \mathrm{m}$ TRANSITION OF ATOMIC IODINE. Engleman R. Jr., Palmer B. A., Davis S. J., J. Opt. Soc. Am. 73, 1585 .

3984. HIGH-RESOLUTION SYNCHRONIZED-QUANTUM-BEAT SPECTROSCOPY USING MODULATION SIDEBANDS: MEASUREMENT OF PRESSURE SHIFTS OF THE HYPERFINE SPLITTING IN SODIUM $3{ }^{2} \mathrm{~S}_{1 / 2}$. Fukuda Y., Tanigawa M., Hashi T., Kondo K., Opt. Lett. 8, 301.

3985. STARK PROFILES OF RESONANCE DOUBLET COMPONENTS IN PLASMA OF THERMONUCLEAR SHELL TARGETS. Gaisinsky I. M., Oks E. A., "Energy Levels and Transition Probabilities in Atoms and Ions," 212-299 (Akad. Nauk SSSR, Otd. Obschch. Fiz. Astron. Nauch. Sov. Spektrosk., Moskva, 1983). 
3986. FAR WING RADIATION FROM ATOM-MOLECULE COLLISIONS. Gallagher A., "Spectral Line Shapes," Vol. 2, 755-767 (Ed. K. Burnett, Walter de Gruyter \& Co., New York, 1983).

3987. FEASIBILITY OF LASER PLASMA DIAGNOSTICS WITH THE AID OF THE SPECTRUM OF A RESONANCE DOUBLET OF HYDROGEN-LIKE IONS IN A STRONG OPTICAL FIELD. Gavrilenko V. P., Oks E. A., Sov. J. Quantum Electron. 13, 1269.

3988. INFORMATION THEORY OF LINE-SHAPE IN COLLISION-INDUCED ABSORPTION. Gburski Z., Gray C. G., Sullivan D. E., Chem. Phys. Lett. 100, 383.

3989. STARK BROADENING OF THE HYDROGEN-RESONANCE LINES $\mathrm{L}_{\alpha}$ AND $\mathrm{L}_{\beta}$ FOR THE ATOM-ION COMBINATIONS H-Ar. Geisler M., Grützmacher K., Wende B., "Spectral Line Shapes," Vol. 2, 37-46 (Ed. K. Burnett, Walter de Gruyter \& Co., New York, 1983).

3990. ELIMINATION OF OUTLYING OBSERVATIONS: A PLASMA SPECTROSCOPY APPLICATION. Gigosos M. A., Mar S., Rev. Acad. Cienc. Exactas, Fis. Quim. Nat. Zaragoza 38,35 .

3991. LIOUVILLIAN GREEN'S-FUNCTION THEORY OF SPECTRAL LINE SHAPE. Girardeau M. D., Hart C. F., Phys. Rev. A 28, 1072.

3992. LIOUVILLIAN GREEN'S FUNCTIONS AND SELF-ENERGIES FOR ENERGY-SHIFT AND DECAY PHENOMENA. Girardeau M. D., Phys. Rev. A 28, 1056.

3993. STARK-WIDTH MEASUREMENTS OF SINGLY IONIZED CALCIUM RESONANCE LINES IN A WALL-STABILIZED ARC. Goldbach Cl., Nollez G., Plomdeur P., Zimmermann J.-P. , Phys. Rev. A 28, 234.

3994. EXPERIMENTAL STARK PARAMETERS FOR SOME LINES OF NEUTRAL CARBON, OXYGEN, AND SULFUR. Goly A., Rakotoarijimy D., Weniger S., J. Quant. Spectrosc. Radiat. Transfer 30, 417.

3995. RADIATION TRANSFER IN A SPECTRAL LINE IN A NONLINEAR ABSORPTION MEDIUM. Gornyi M. B., Markman D. L., Matisov B. G., Opt. Spectrosc. (USSR) 55, 20.

3996. GRAVITATIONAL AND PRESSURE REDSHIFTS IN WHITE-DWARF STARS. Grabowski B., Halenka J., Madej J., "Proceedings of the Sixteenth Int. Conf. on Phenomena in Ionized Gases, Vol. 4, Contributed Papers," 104-105 (Eds. W. Butticher, H. Wenk \& E. Schulz-Gulde, Organ. Comm. ICPIG XVI, Dusseldorf, WG, 1983). 
3997. FURTHER EXAMINATION OF STARK BROADENING BY ION PERTURBERS. Greene R. L., J. Quant. Spectrosc. Radiat. Transfer 30, 409.

3998. SHIFTS OF HYDROGEN LINES FROM ELECTRON COLLISIONS IN DENSE PLASMAS. Griem H. R., Phys. Rev. A 28, 1596.

3999. SHIFTS OF IONIZED-HELIUM LINES FROM ELECTRON COLLISIONS IN DENSE PLASMAS. Griem H. R., Phys. Rev. A 27, 2566.

4000. MEASUREMENTS OF PLASMA ION TEMPERATURE AND ROTATION VELOCITY USING THE He II $4686 \AA$ LINE PRODUCED BY CHARGE TRANSFER. Groebner R. J., Brooks N. H., Burrel1 K. H., Rottler L., App1. Phys. Lett. 43, 920.

4001. STABLE REDUCTION OF MOLECULAR SPECTRA TO AN IDEAL INSTRUMENT. Grushetskii K. M. , Akhrem A. A., Sov. Phys.--Dokl. 28, 666.

4002. INTERATOMIC POTENTIALS FOR THE Hg-Xe SYSTEM FROM MEASUREMENTS OF THE TEMPERATURE-DEPENDENT ABSORPTION SPECTRUM. Grycuk T., Findeisen M., J. Phys. B 16, 975 .

4003. HIGH PRECISION MEASUREMENTS OF ATOMIC LEVEL SPLITTINGS BY MEANS OF PERIODIC PUMPING WITH PICOSECOND LIGHT PULSES. Harde H., Burggraf H., Springer Ser. Opt. Sci. 40, (Laser Spectrosc. 6), 117.

4004. STUDIES OF COLLISIONAL BROADENING OF SPECTRAL LINES AND INTERACTION BETWEEN ATOMS. Harima H., Tachibana K., Urano Y., Mem. Fac. Ind. Arts, Kyoto Tech. Univ. Sci. Technol. 32, 22.

4005. ABSORPTION COEFFICIENTS FOR THE WINGS OF THE Sr RESONANCE LINE AT $4607 \AA$ BROADENED BY He, Ne AND Kr. Harima H., Yanagisawa T., Tachibana K., Urano Y., J. Phys. B 16, 4365.

4006. ABSORPTION COEFFICIENTS FOR THE WINGS OF THE Ca RESONANCE LINE AT $4227 \AA$ BROADENED BY RARE GASES. Harima H., Yanagisawa T., Tachibana K., Urano Y., J. Phys. B 16, 4529.

4007. OBSERVATION OF STARK-SHIFTS OF LYMAN- $\alpha$ LINES OF LOW-Z IONS IN LASER-PRODUCED PLASMAS. Hashimoto S., Yamaguchi N., Phys. Lett. A 95, 299.

4008. FINE-STRUCTURE TRANSITIONS OCCURRING IN COLLISIONAL REDISTRIBUTION OF LIGHT. Havey M. D., Copeland G. E., Wang W. J., Phys. Rev. Lett. 50, 1767. 
4009. STOCHASTIC ASPECTS IN THE THEORY OF SPECTRAL-LINE BROADENING. I. COLLISION TIME STATISTICS AND N-PERTURBER LIMIT. Hegerfeldt G. C., Reibold R., J. Stat. Phys. 32, 313.

4010. STOCHASTIC ASPECTS IN THE THEORY OF SPECTRAL-LINE BROADENING. II. NONCOMMUTATIVE CLUSTER EXPANSIONS. Hegerfeldt G. C., Reibold R., J. Stat. Phys. 32, 337.

4011. IMPACT BROADENING OF ALKALI RYDBERG LEVELS IN PURE AND MIXED ALKALI VAPORS. Heinke H., Lawrenz J., Niemax K., Weber K.-H., Z. Phys. A 312, 329.

4012. INVESTIGATION OF THE STARK BROADENING OF BALMER BETA. Helbig V., Fu F. S., Nick K. P., "Spectral Line Shapes," Vol. 2, 47-54 (Ed. K. Burnett, Walter de Gruyter \& Co., New York, 1983).

4013. COMPOSITION EFFECTS IN STARK BROADENING OF HYDROGENIC LINES EMITTED BY HEAVY IONS IN INERTIALLY CONFINED PLASMAS. Held B., Deutsch C., Gombert M. M., Phys. Rev. A 28, 3134.

4014. SPECTRAL LINE LIMITING AND POLARIZATION SHIFT IN PLASMAS OF HIGH PARTICLE AND ENERGY DENSITY. Henry B. I., Laser and Particle Beams 1, 11.

4015. POLARIZATION SHIFT OF SPECTRAL LINES IN HIGH DENSITY PLASMAS. Henry $B$. I., Hora H., Opt. Commun. 44, 185.

4016. COMPREHENSIVE THEORY FOR LINE BROADENING IN HIGH-RESOLUTION AND NON-LINEAR SPECTROSCOPIES: APPLICATION TO THE Na D LINES. Herman R. M., Weber E. W., J. Phys. B 16, 1323.

4017. SPECTRAL LINE SHIFT OF NEUTRAL XENON AT HIGH ELECTRON DENSitiES. Hess H., Hitzschke L., Metzke E., Werner H., Wirsig M., "Proceedings of the Sixteenth Int. Conf. on Phenomena in Ionized Gases, Vol. 4, Contributed Papers," 622-623 (Eds. W. Butticher, H. Wenk \& E. Schulz-Gulde, Organ. Comm. ICPIG XVI, Dusseldorf, WG, 1983).

4018. TEMPORALLY AND SPATIALLY RESOLVED PLASMA SATELLITES IN A HOLLOW-CATHODE SOURCE. Hildebrandt J., J. Phys. B 16, 149.

4019. VOLTAGE MODULATION IN A PULSED HOLLOW-CATHODE DISCHARGE AND ITS RELATION TO THE OCCURRENCE OF PLASMA SATELLITES. Hildebrandt J., Phys. Lett. A 95,365 . 
4020. REDISTRIBUTION OF RADIATION IN A STARK-BROADENED LINE PROFILE. Himmel G., Sowa L., J. Phys. B 16, 4117.

4021. DETERMINATION OF LINE BROADENING PARAMETERS FOR CHROMIUM TRIPLET LINES ( ${ }^{7} \mathrm{~S}-\mathrm{z}^{7} \mathrm{P}^{\circ}$ TRANSITION) IN AN $\mathrm{C}_{2} \mathrm{H}_{2}$-AIR FLAME. Hollander $\mathrm{T} j$, Leeuw A. de, Horst E. ter, Spectrochim. Acta, Part B 38, 691.

4022. ABSORPTION AND EMISSION LINE PROFILE COEFFICIENTS OF MULTILEVEL ATOMS-I. ATOMIC PROFILE COEFFICIENTS. Hubeny I., Oxenius J., Simonneau E., J. Quant. Spectrosc. Radiat. Transfer 29, 477.

4023. ABSORPTION AND EMISSION LINE PROFILE COEFFICIENTS OF MULTILEVEL ATOMS . - I . VELOCITY-AVERAGED PROFILE COEFFICIENTS. Hubeny I., Oxenius J., Simonneau E., J. Quant. Spectrosc. Radiat. Transfer 29, 495.

4024. SELF-BROADENING OF THE SODIUM RESONANCE LINES AND EXCITATION TRANSFER BETWEEN THE $3 \mathrm{P}_{3 / 2}$ AND 3 $\mathrm{P}_{1 / 2}$ LEVELS. Huennekens J., Gallagher A., Phys. Rev. A 27, 1851 .

4025. RESONANCE BROADENING OF THE SODIUM D LINES. Huennekens J., Gallagher A., "Spectral Line Shapes," Vol. 2, 665-677 (Ed. K. Burnett, Walter de Gruyter \& Co., New York, 1983).

4026. SPECTRUM PROFILES IN THE PRESENCE OF SEVERAL BROADENING EFFECTS. Humlicek J., J. Quant. Spectrosc. Radiat. Transfer 29, 125.

4027. CORRELATIONS IN THE PLASMA BROADENING OF ION SPECTRAL LINES. Iglesias' C. A., J. Quant Spectrosc. Radiat. Transfer 30, 55.

4028. INTEGRAL-EQUATION METHOD FOR ELECTRIC MICROFIELD DISTRIBUTIONS. Iglesias C. A., Phys. Rev. A 27, 2705.

4029. ION-ELECTRON GORRELATIONS IN SPECTRAL LINE SHAPE THEORY. Iglesias C. A., Dufty J., "Spectral Line Shapes," Vol. 2, 55-69 (Ed. K. Burnett, Walter de Gruyter \& Co., New York, 1983).

4030. SOME APPROXIMATE MICROFIELD DISTRIBUTIONS FOR MULTIPLY IONIZED PLASMAS: A CRITIQUE. Iglesias C. A., Hooper C. F. Jr., DeWitt H. E., Phys. Rev. A 28,361 . 
4031. ELECTRIC MICROFIELD DISTRIBUTIONS IN STRONGLY COUPLED PLASMAS. Iglesias C. A., Lebowitz J. L., MacGowan D., Phys. Rev. A 28, 1667.

4032. MEASUREMENT OF THE STARK BROADENING BY PLASMAS OF THE NEUTRAL ARGON LINE $13406.6 \AA$. Iglesias E., Guimerans Y., Castell R., Mandelbaum D., Sanchez A., Acta Cient. Venezolana 34, 84.(Span.)

4033. STARK WIDTHS AND SHIFTS FOR SOME Ar I 4s-4p TRANSITIONS. Jones D. W., Musiol K., Wiese W. L., "Spectral Line Shapes," Vol. 2, 125-136 (Ed. B. Wende, Walter de Gruyter \& Co., New York, 1983).

4034. SOME OBSERVATIONS ON THE RESOLUTION ENHANCEMENT OF SPECTRAL DATA BY THE METHOD OF SELF-DECONVOLUTION. Jones R. N., Shimokoshi K., Appl. Spectrosc. 37, 59.

4035. EFFECT OF SELF ABSORPTION ON EMITTED INTENSITY OF Na-5890 \& LINE IN WATER GAS COMBUSTION PLASMA. Joshi N. K., Rohatgi V. K., Int. J. Energy 7, 155.

4036. Rb AND Cs BROADENING OF THE Na RESONANCE LINES. Kamke B., Kamke W., Niemax K., Gallagher A., Phys. Rev. A 28, 2254.

4037. PLASMA TEMPERATURE DETERMINATION FROM THE MAXIMUM INTENSITY OF A SYMMETRIC SELF-REVERSED LINE. Karabourniotis D., J. Phys. D 16, 1267; 17, 1325 (1984).

4038. BROADENING OF SPECTRAL LINES IN OPTICALLY THICK PLASMAS. Karabourniotis D., Karras C., "Proceedings of the Sixteenth Int. Conf. on Phenomena in Ionized Gases, Vol. 4, Contributed Papers," 640-641 (Eds. W. Butticher, H. Wenk \& E. Schulz-Gulde, Organ. Comm. ICPIG XVI, Dusseldorf, WG, 1983).

4039. COLLISION BROADENING AND SHIFT OF EXCITED s STATES IN THALLIUM. Kielkopf J. F., J. Phys. B 16, 3149.

4040. NEUTRAL COLLISION BROADENING OF 6P-NS TRANSITIONS IN THALLIUM. Kielkopf J. F., "Spectral Line Shapes," Vol. 2, 467-478 (Ed. K. Burnett, Walter de Gruyter \& Co., New York, 1983).

4041. ON THE STARK BROADENING OF NON-HYDROGENIC LINES OF HEAVY ELEMENTS IN PLASMAS. Konjevic N., Dimitrijevic M. S., "Spectral Line Shapes," Vol. 2, 137-146 (Ed. K. Burnett, Walter de Gruyter \& Co., New York, 1983). 
4042. HIGH-RESOLUTION LINE-SHAPE ANALYSES OF THE PULSED CUPROUS CHLORIDE-LASER OSCILLATOR AND AMPLIFIER. Kreye W. C., Roesler F. L., Appl. Opt. 22, 927.

4043. CALCUlation OF THE VOIGT FUNCTION AT THE CENTER OF A Line. Kudrya V. P., Opt. Spectrosc. (USSR) 55, 679.

4044. THEORETICAL DETERMINATION OF FINE-STRUCTURE TRANSITIONS OCCURRING IN COLLISIONAL REDISTRIBUTION OF LIGHT. Kulander K. C., Rebentrost F., Phys. Rev. Lett. $51,1262$.

4045. NATURAL SPECTRAL LINE WIDTH AND SHAPE IN THE RELATIVISTIC THEORY OF THE ATOM. Labzovskii L. N., Sov. Phys.--JETP 58, 503.

4046. ESTIMATED STARK WIDTHS AND SHIFTS OF NEUTRAL ATOM AND SINGLY CHARGED ION RESONANCE LINES. Lakicevic I. S., Astron. Astrophys. 127, 37.

4047. STARK SHIFT TRENDS IN HOMOLOGOUS IONS. Lakicevic I. S., Puric J., J. Phys. B 16, 1525 .

4048. EXPERIMENTAL STARK WIDTHS AND SHIFTS OF Cr II LINES. Lakicevic I. S., Rathore B. A., Cuk M., Puric J., "Proceedings of the Sixteenth Int. Conf. on Phenomena in Ionized Gases, Vo1. 4, Contributed Papers," 624-625 (Eds. W. Butticher, H. Wenk \& E. Schulz-Gulde, Organ. Comm. ICPIG XVI, Dusseldorf, WG, 1983).

4049. ON THE STARK BROADENING AND SHIFT REGULARITIES. Lakicevic I. S., Puric J., "Spectral Line Shapes," Vol. 2, 147-160 (Ed. K. Burnett, Walter de Gruyter \& Co., New York, 1983).

4050. SUITABLE SPECTRAL LINE SHAPE CALCULATIONS FOR INERTIAL CONFINEMENT PLASMA DIAGNOSIS. Lambert D., Louis-Jacquet M., "Spectral Line Shapes," Vol. 2, 291-313 (Ed. K. Burnett, Walter de Gruyter \& Co., New York, 1983).

4051. HIGH DENSITY ATOMIC AND MOLECULAR SPECTRA OF XENON IN THE WAVELENGTH RANGE 120-170 nm. Laporte P., Subtil J. L., Castex M. C., "Spectral Line Shapes," Vo1. 2, 583-596 (Ed. K. Burnett, Walter de Gruyter \& Co., New York, 1983).

4052. SOME RESULTS OF PLASMA MICROFIELD COMPUTER EXPERIMENTS. Larenz R. W., Ottersbach G., "Proceedings of the Sixteenth Int. Conf. on Phenomena in Ionized Gases, Vol. 4, Contributed Papers," 14-15 (Eds. W. Butticher, H. Wenk \& E. Schulz-Gulde, Organ. Comm. ICPIG XVI, Dusseldorf, WG, 1983). 
4053. TIME DEPENDENT STARK BROADENING MEASUREMENTS IN PLANAR-LASER TARGET EXPERIMENTS. Lee R. W., Kilkenny J. D., Kauffman R. L., Matthews D. L., "Spectral Line Shapes," Vol. 2, 247-264 (Ed. K. Burnett, Walter de Gruyter \& Co., New York, 1983).

4054. STARK WIDTHS AND SHIFTS OF SINGLY IONIZED SILICON SPECTRAL LINES. Lesage A., Rathore B. A., Lakicevic I. S., Puric J., Phys. Rev. A 28, 2264.

4055. LONG RANGE INTERATOMIC POTENTIALS AND LINE BROADENING. Lewis E. L., "Spectral Line Shapes," Vol. 2, 429-443 (Ed. K. Burnett, Walter de Gruyter \& Co., New York, 1983).

4056. THE POLARIZATION OF REDISTRIBUTED LIGHT, SPECTRAL SATELLITES AND INTERATOMIC POTENTIALS. Lewis E. L., Harris M., J. Phys. B 16, L687.

4057. THE POLARIZATION OF COLLISIONALLY REDISTRIBUTED ATOMIC FLUORESCENCE. Lewis E. L., Harris M., Alford W. J., Cooper J., Burnett K., J. Phys. B 16,553 .

4058. EXPERIMENTAL STUDY OF STIMULATED RADIATIVE CORRECTIONS ON AN ATOMIC RYDBERG STATE. Liberman S., Pinard J., Taleb A., Phys. Rev. Lett. 50, 888.

4059. INFLUENCE OF $\mathrm{SF}_{6}$ ON THE BROADENING AND SHIFT OF THE $535.0 \mathrm{~nm}$ THALLIUM LINE. Lisicki E., Bobkowski R., Szudy J., Wolnikowski J., Z. Naturforsch., Teil A 38, 838.

4060. ON ONE METHOD TO STUDY LOW-FREQUENCY PLASMA ELECTRIC FIELDS FROM STARK BROADENING OF HYDROGEN LINES. Ljublin B. V., Yakovlev D. G., "Proceedings of the Sixteenth Int. Conf. on Phenomena in Ionized Gases, Vol. 4, Contributed Papers, " 410-411 (Eds. W. Butticher, H. Wenk \& E. Schulz-Gulde, Organ. Comm. ICPIG XVI, Dusseldorf, WG, 1983).

4061. REDISTRIBUTION OF RADIATION IN A LOW DENSITY PLASMA. Lombardi G. G., Kelleher D. E., "Spectral Line Shapes," Vol. 2, 835-845 (Ed. K. Burnett, Walter de Gruyter \& Co., New York, 1983).

4062. LEVEL-CROSSING STUDY OF DEPOLARIZING COLLISIONS IN $6{ }^{2} \mathrm{P}_{3 / 2}$ STATE OF RUBIDIUM AND $7{ }^{2} \mathrm{P}_{3 / 2}$ STATE OF CESIUM. Lukaszewski M., Jackowska I., Opt. Commun. 46, 89 . 
4063. COLLISIONAL BROADENING OF LEVEL-CROSSING SIGNALS. DEPOLARIZATION OF $5{ }^{2} \mathrm{P}_{3 / 2}$ STATE OF Rb IN COLLISIONS WITH NOBLE-GAS ATOMS. Lukaszewski M., Jackowska I., Acta Physica Pol. A 64, 663.

4064. BROADENING OF LEVEL-CROSSING SIGNALS IN THE $5{ }^{2} \mathrm{P}_{3 / 2}$ STATE OF RUBIDIUM DUE TO RESONANT COLLISIONS. Lukaszewski M., Jackowska I., Phys. Lett. A 95 , 429.

4065. HYDROGEN LINE BROADENING IN THE PRESENCE OF A MAGNETIC FIELD WITH THE UNIFIED CLASSICAL PATH THEORY. Mathys G., Astron. Astrophys. 125, 13.

4066. ANALYSIS OF LASER LIGHT SCATTERED BY COLD, DENSE HYDROGEN PLASMAS PRODUCED IN A Z PINCH. Maurmann S., Kunze H. J., Phys. Fluids 26, 1630.

4067. ROLE OF MOLECULAR DISSOCIATION AND CHARGE EXCHANGE IN THE SHAPE OF ATOMIC SPECTRUM LINES IN LOW-DENSITY HYDROGEN PLASMAS. McNeill D. H., "Spectral Line Shapes," Vol. 2, 71-85 (Ed. K. Burnett, Walter de Gruyter \& Co., New York, 1983).

4068. STARK-SHIFTS OF THE He II SPECTRAL LINES. Murakawa K., J. Phys. Soc. Jpn $52,1969$.

4069. $\mathrm{O}_{2}$ PRESSURE BROADENING OF THE IODINE ${ }^{2} \mathrm{P}_{1 / 2}-{ }^{2} \mathrm{P}_{3 / 2}$ TRANSITION. Neumann D. K., Clark P. K., Shea R. F., Davis S. J., J. Chem. Phys. 79, 4680.

4070. NEUTRAL GAS LINE BROADENING AND SHIFT IN SPECTRAL SERIES. Niemax K., "Spectral Line Shapes," Vol. 2, 917-926 (Ed. K. Burnett, Walter de Gruyter \& Co., New York, 1983).

4071. CORRELATION EFFECTS IN COLLISIONAL DEPOLARIZATION AND REDISTRIBUTION OF RADIATION. Nienhuis G., J. Phys. B 16, 1.

4072. REDISTRIBUTION AS A PROBE OF ATOMIC COLLISIONS. Nienhuis G., "Spectral Line Shapes," Vol. 2, 847-860 (Ed. K. Burnett, Walter de Gruyter \& Co., New York, 1983).

4073. COLLISIONAL DEPOLARIZATION OF THE Na-D ${ }_{2}$ FLUORESCENCE AT LINE WING EXCITATION IN A $\mathrm{N}_{2}$-DILUTED $\mathrm{H}_{2} / \mathrm{O}_{2}$ FLAME AT 1 ATM. Nieuwesteeg $\mathrm{K}$. J., Hollander Tj., Alkemade C. Th. J., J. Quant. Spectrosc. Radiat. Transfer $30,97$. 
4074. KILOMETER PATH-LENGTH ABSORPTION MEASUREMENTS OF THE COLLISION-INDUCED He I $2{ }^{3} \mathrm{P}-3^{1} \mathrm{D}$ InTERCOMBINATION SATELLite. Nightingale M. P. S., Burgess D. D., J. Phys. B 16, 4091 .

4075. ARE PLASMA SATELLITES PRESENT AMONG CHROMOSPHERIC LINES ?. Öhman Y., Sol. Phys. 85, 53 .

4076. ANODE PLASMA DENSITY MEASUREMENTS IN A MAGNETICALLY INSULATED DIODE. Pal R. Hammer D., Phys. Rev. Lett. 50, 732.

4077. HIGH RESOLUTION $\left(\Delta \lambda_{\text {FWHM }}<0.08 \AA\right.$ ) HELIUM LINE PROFILES IN A LOW DENSITY LINEAR DISCHARGE. Pease D. C., Bengtson R. D., "Spectral Line Shapes," Vol. 2, $199-214$ (Ed. K. Burnett, Walter de Gruyter \& Co., New York, 1983).

4078. EXPERIMENTAL STUDY OF ION DYNAMIC EFFECTS IN OVERLAPPING HELIUM LINES AT LOW DENSITIES. Piel A., Richter H., Z. Naturforsch. Teil A 38, 37.

4079. INVESTIGATION OF ION DYNAMIC EFFECTS IN HELIUM LINES AT LOW ELECTRON DENSITIES BY VARIATION OF THE PERTURBER MASS. Piel A., Richter H., "Proceedings of the Sixteenth Int. Conf. on Phenomena in Ionized Gases, Vol. 4, Contributed Papers," 634-635 (Eds. W. Butticher, H. Wenk \& E. Schulz-Gulde, Organ. Comm. ICPIG XVI, Dusseldorf, WG, 1983).

4080. RED SHIFT OF THE He II H $\alpha$ and P $\alpha$ LINES. Pittman T. L., Fleurier C., "Spectral Line Shapes," Vol. 2, 87-100 (Ed. K. Burnett, Walter de Gruyter \& Co., New York, 1983).

4081. EVALUATION OF SPECTRAL LINE PROFILE FROM RELATIVE WIDTHS OF FABRY-PEROT INTERFEROGRAMS. Platisa M., Konjevic R., Bukvic S., Opt. Laser Technol. $15,209$.

4082. TRANSITION REGIONS IN LINE BROADENING. Pritchard D. E., Walkup R. E., "Spectral Line Shapes," Vol. 2, 445-459 (Ed. K. Burnett, Walter de Gruyter \& Co., New York, 1983).

4083. EXPERIMENTAL STARK WIDTHS AND SHIFTS OF Co I LINES. Puric J., Lakicevic I. S., Rathore B. A., Cuk M., "Proceedings of the Sixteenth Int. Conf. on Phenomena in Ionized Gases, Vol. 4, Contributed Papers," 626-627 (Eds. W. Butticher, H. Wenk \& E. Schulz-Gulde, Organ. Comm. ICPIG XVI, Dusseldorf, WG, 1983). 
4084. STARK WIDTHS AND SHIFTS OF IV AND V GROUP HOMOLOGOUS IONS. Puric J., Lakicevic I. S., "Spectral Line Shapes," Vo1. 2, 161-174 (Ed. K. Burnett, Walter de Gruyter \& Co., New York, 1983).

4085. DETERMINATION OF GESIUM ION-RARE GAS POTENTIALS FROM TOTAL GROSS SECTION MEASUREMENTS. Rajan M. S., Gislason E. A., J. Chem. Phys. 78, 2428.

4086. STARK BROADENING PARAMETER TRENDS FOR IONIZED RARE GAS AND MIRROR IMAGE ELEMENTS. Richou J., Manola S., Lesage A., Abadie D., Miller M. H., "Proceedings of the Sixteenth Int. Conf. on Phenomena in Ionized Gases, Vo1. 4, Contributed Papers," 632-633 (Eds. W. Butticher, H. Wenk \& E. Schulz-Gulde, Organ. Comm. ICPIG XVI, Dusseldorf, WG, 1983).

4087. STUDY OF THE PRESSURE BROADENING OF THE $587.6 \mathrm{~nm}$ HELIUM AND THE $588.2 \mathrm{~nm}$ NEON LINES. Röhe-Hansen J., Helbig V., "Spectral Line Shapes," Vo1. 2, 961-969 (Ed. K. Burnett, Walter de Gruyter \& Co., New York, 1983).

4088. BROADENING OF HYPERFINE COMPONENTS OF $\mathrm{Na}$ D LINES PERTURBED BY He. Roueff E., Spielfiedel A., "Spectral Line Shapes," vol. 2, 479-482 (Ed. K. Burnett, Walter de Gruyter \& Co., New York, 1983).

4089. H I LYMAN-ALPHA IN THE SUN: THE EFFECTS OF PARTIAL REDISTRIBUTION IN THE LINE WINGS. Roussel-Dupré D., Astrophys. J. 272, 723.

4090. EXPANSIONS AROUND THE GAUSSIAN AND LORENTZIAN LIMITS FOR RANDOMLY PERTURBED SPECTRAL LINES AND THEIR SHIFT, WIDTHS, AND ASYMMETRY. Royer A., J. Math. Phys. 24, 380 .

4091. SHIFT, WIDTH AND ASYMMETRY OF PRESSURE PERTURBED SPECTRAL LINES AT LOW DENSITIES. Royer A., "Spectral Line Shapes," Vo1. 2, 483-495 (Ed K. Burnett, Walter de Gruyter \& Co., New York, 1983).

4092. THEORETICAL ANALYSIS OF SPECTRAL LINES OF ONE-AND TWO-ELECTRON IONS IN HOT PLASMAS. Rozsnyai B. F., Einwohner T., "Spectral Line Shapes," Vol. 2, 315-327 (Ed. K. Burnett, Walter de Gruyter \& Go., New York, 1983).

4093. THE USE OF COMPUTERS IN THE INVESTIGATION OF OPTICALLY THICK INHOMOGENEOUS PLASMAS BY THEIR EMISSION AND ABSORPTION SPEGTRA. Salakhov M. Kh., Sarandayev E. V., Fishman I. S., Comput. Enhanced Spectrosc. 1, 213. 
4094. DETAILED BALANCE IN THEORY OF PRESSURE-BROADENING OF ATOMIC LINES. Sando K. M., Herman P. S., "Spectral Line Shapes," Vol. 2, 497-514 (Ed. K. Burnett. Walter de Gruyter \& Co., New York, 1983).

4095. EVIDENCE OF ANOMALOUS MULTIPLET LINE SHAPES IN OPTICALLY THICK, LASER-PRODUCED PLASMAS. Santi D., Nicolosi P., J. Quant. Spectrosc. Radiat. Transfer 29, 549.

4096. DOPPLER BROADENING OF SPECTRAL LINES UNDER EXCITATION BY DIRECT ELECTRON IMPACT. Savinov S. Yu., Tskhai S. N., Sov. Phys.--Lebedev Inst. Rep. No. 9,1 .

4097. PLASMA BROADENING OF HYDROGEN TWO-PHOTON ABSORPTION LINES. Seidel J., "Spectral Line Shapes," Vol. 2, 381-393 (Ed. K. Burnett, Walter de Gruyter \& Co., New York, 1983).

4098. INTERACTION BETWEEN QUANTUM CALCULATION OF POTENTIAL ENERGY CURVES AND EXPERIMENTS FOR THE INTERPRETATION AND SIMULATION OF LINE PROFILES: THE ARGON EXCIMER EXAMPLE. Spiegelmann F., Caste M. C., Ann. Phys. (Paris) 8, 199.(Fr.)

4099. SELF-BROADENING AT LOW DENSITIES IN THE SPECTRUM OF NEON. Stacey D. N., Thompson R. C., J. Phys. B 16, 537.

4100. SIMULATION STUDIES OF THE DYNAMICS OF PLASMA MICROFIELDS. Stamm R., "Spectral Line Shapes," Vol. 2, 3-29 (Ed. K. Burnett, Walter de Gruyter \& Co., New York, 1983).

4101. COLLISIONAL BROADENING OF THE ATOMIC FLUORINE ${ }^{2} \mathrm{P}_{1 / 2}-{ }^{2} \mathrm{P}_{3 / 2}$ SPIN ORBIT TRANSITION. Stanton A. C., Wormhoudt J. C., Duff J. W.," "Spectral Line Shapes," Vol. 2, 515-529 (Ed. K. Burnett, Walter de Gruyter \& Co., New York, 1983).

4102. STARK BROADENING OF HYDROGEN LINES: NEW RESULTS FOR THE BALMER LINES AND ASTROPHYSICAL CONSEQUENCES. Stehlé C., Mazure A., Nollez G., Feautrier N. , Astron. Astrophys. 127, 263; 255, 368 (1988).

4103. TIME-DEPENDENT BEHAVIOR OF HIGH-PRESSURE MERCURY DISCHARGES. Stormberg H. P., Schäfer R., J. Appl. Phys. 54, 4338. 
4104. A SIMPLE METHOD FOR CALCULATING VOIGT-PROFILES BY A PROGRAMMABLE HAND-CALCULATOR HP-34C. Sulzmann K. G. P., J. Quant. Spectrosc. Radiat. Transfer 29, 89 .

4105. REPULSIVE VAN DER WAALS AND DIPOLE-QUADRUPOLE INTERACTION IN THE EXCITED LiCs MOLECULE. Vadla C., Lorenzen C.-J., Niemax K., Phys. Rev. Lett. 51 , 988.

4106. EFFECT OF A STRONG RADIATION FIELD ON THE SPECTRAL LINE SHAPE. Vallee 0., Tran Minh N., Chapelle J., Ann. Phys. (Paris) 8, 183.(Fr.)

4107. COLLISIONAL PROCESSES BY FOURIER TRANSFORM SPECTROSCOPY. Vergès J., Ann. Phys. (Paris) 8, 187.(Fr.)

4108. PROFILE DECONVOLUTION METHOD FOR SMALL COMPUTERS. Verma R., Nuc1. Instrum. Methods 212, 323.

4109. TRIPLET SATELLITE IN VERY FAR BLUE WING OF THE SELF-BROADENED LITHIUM D-LINE. Veza D., Milosevic S., Pichler G., "Spectral Line Shapes," Vol. 2, 679-687 (Ed. K. Burnett, Walter de Gruyter \& Co., New York, 1983).

4110. PECULIAR ASYMMETRY IN THE WINGS OF SELF-BROADENED Li AND Na FIRST RESONANCE LINES. Veza D., Pichler G., Opt. Commun. 45, 39.

4111. UNIFORM SEMICLASSICAL DESCRIPTION OF SATELLITE BANDS. Vicharelli P. A., Collins C. B., "Spectral Line Shapes," Vo1. 2, 537-549 (Ed. K. Burnett, Walter de Gruyter \& Co., New York, 1983).

4112. EXPERIMENTAL INVESTIGATION OF BROADENING PARAMETERS OF He I $2{ }^{1} \mathrm{P}-4^{1} \mathrm{D}$ (492,2 nm) LINE AND ITS FORBIDDEN COMPONENT $2{ }^{1} \mathrm{P}-4{ }^{1} \mathrm{~F}$ IN A LASER PRODUCED PLASMA. Vujicic B. T., Cirkovic Lj. M., "Proceedings of the Sixteenth Int. Conf. on Phenomena in Ionized Gases, Vol. 4, Contributed Papers," 642-643 (Eds. W. Butticher, H. Wenk \& E. Schulz-Gulde, Organ. Comm. ICPIG XVI, Dusseldorf, WG, 1983).

4113. HALF-WIDTHS OF NEUTRAL FLUORINE SPECTRAL LINES. Vujnovic V., Vadla C., Lokner V., Dimitrijevic M. S., Astron. Astrophys. 123, 249.

4114. NEAR-ULTRAVIOLET EMISSION BANDS OF Li-RARE-GAS MOLECULES. Wang W. J., Havey M. D., Phys. Rev. A 29, 3184. 
4115. NONLINEAR PLASMA SPECTROSCOPY OF THE HYDROGEN BALMER- $\alpha$ LINE. Weber E. W., Frankenberger R., Schilling M., Appl. Phys. B 32, 63.

4116. IMPACT BROADENING OF VERY HIGH Rb RYDBERG LEVELS BY Xe. Weber K. H., Niemax K., Z. Phys. A 312, 339.

4117. HIGH-FREQUENCY STARK-EFFECT MEASUREMENTS IN EMISSION SPECTROSCOPY. Wiegart N. J., Phys. Rev. A 27, 2114.

4118. COMMENT ON "PLASMA SATELLITES IN THE PRESENCE OF NON-RESONANT, COHERENT AND POLARIZED RADIATION." Wiegart N. J., Rebhan U., J. Phys. B 16, L367.

4119. MEASUREMENT OF ELECTRON CONCENTRATIONS BY HYDROGEN LINE-BROADENING USING A PHOTODIODE ARRAY SPECTROMETER. Williams R. R., Coleman G. N., Spectrochim. Acta, Part B 38, 1171.

4120. INFRARED EMISSION SPECTRA OF AN ARGON PLASMA-JET IN THE 4 TO $25 \mu$ m RANGE. Winkelmann G., Tilgner J., Beitr. Plasmaphys. 23, 193.(Ger.)

4121. A FULL COULOMB CALCULATION OF STARK BROADENING IN DENSE PLASMA: LINE SHAPES, SHIFTS, AND ASYMMETRIES. Woltz L. A., Hooper C. F. Jr., "Spectral Line Shapes," Vo1. 2, 337-351 (Ed. K. Burnett, Walter de Gruyter \& Co., New York, 1983).

4122. PHOTON-ECHO STUDIES OF COLLISIONAL RELAXATION IN WEAKLY IONIZED NOBLE-GAS MIXTURES. Woodworth M. R., Opt. Lett. 8, 307.

4123. HIGH-DENSITY DIAGNOSTICS FOR LASER-IMPLODED PLASMAS. Yamamoto K., Narumi H., J. Phys. Soc. Jpn 52, 520.

4124. VAN DER WAALS BROADENING COEFFICIENTS OF HIGHLY EXCITED ARGON LINES. Zarovnyaev G. V., Khakhaev A.D., Opt. Spectrosc. (USSR) 54, 346.

\section{4}

4125. COMPARATIVE ANALYSIS OF THREE PROCEDURES FOR CALCULATION OF THE VOIGT PROFILE OF A SPECTRAL LINE. Afonin S. V., Gaponov V. A., Gendrin A. G., J. App1. Spectrosc. (USSR) 41, 868 .

4126. LOCAL MEASUREMENTS OF THE HOMOGENEOUS WIDTH OF A SPECTRAL LINE IN A PLASMA. Akhmedzhanov R. A., Polushkin I. N., Khanin Ya. I., Yazenkov V. V., Sov. J. Plasma Phys. 10, 502. 
4127. NEW SYSTEMATIC EXPANSION OF THE ELECTRIC FIELD DISTRIBUTION IN PLASMAS. Alastuey A., Iglesias C. A., Lebowitz J. L., Levesque D., Phys. Rev. A 30,2537 .

4128. BROADENING AND SHIFT OF THULIUM RESONANCE LINES BY HELIUM. Aleksandrov E. B., Vedenin V. D., Kulyasov V. N., Opt. Spectrosc. (USSR) 56, 365.

4129. COLLISIONAL REDISTRIBUTION OF LIGHT: FAR-WING LINE SHAPES AND POLARIZATION FOR THE Ba-(Ar,Xe) SYSTEMS. Alford W. J., Andersen N., Burnett K., Cooper J., Phys. Rev. A 30, 2366.

4130. ALKALI-RARE GAS INTERACTION POTENTIAL MODELISATION BY SQUARE-WELL POTENTIALS: PHYSICAL INTERPRETATION. Allard N. F., Biraud Y. G., Ann. Phys. (Paris) 9, 585.

4131. MEASUREMENT OF STARK BROADENING OF He II $4686 \AA$. Arata Y., Miyake S., Matsuoka H., J. Quant. Spectrosc. Radiat. Transfer 32, 343.

4132. THERMAL PLASMA DIAGNOSTICS US ING TUNABLE DYE LASER (REPORT II). Arata Y., Miyake S., Matsuoka H., Trans. JWRI 13, 13.

4133. STIMULATED EMISSION OF THE $535 \mathrm{~nm}$ THALLIUM LINE AS A RESULT OF QUASIRESONANT OPTICAL PUMPING OF A TI-He MIXTURE BY RADIATION FROM A RECOMBINATION He-Ca LASER. Atamas S. N., Bukshpun L. M., Koptev Yu. V., Latush E. L., Sem M. F., Sov. J. Quantum Electron. 14, 161.

4134. HIGH-RESOLUTION K-SHELL DIELECTRONIC SATELLITE LINES FROM LASER-IRRADIATED SPOT TARGETS AT $1.06,0.53$, AND $0.27 \mu \mathrm{m}$ WAVELENGTH. Audebert P., Geindre J. P., Gauthier J. C., Popovics C., Phys. Rev. A 30,768 .

4135. TEMPERATURES AND DENSITIES IN A VACUUM SLIDING SPARK DETERMINED FROM XUV EMISSION LINES. Bäckström M., Pettersson L., Nordgren J., Phys. Scr. 29, 568 .

4136. APPLICATION OF COHERENT VUV RADIATION TO THE MEASUREMENT OF LYMAN- $\alpha$ ABSORPTION LINESHAPES IN A DENSE Z-PINCH PLASMA. Baldwin K. G. H., Marangos J. P., Burgess D. D., J. Phys, D 17, L169.

4137. LINE BROADENING BY ELECTRONS IN HOT PLASMAS. Banon J., Koenig M., Nguyen Hoe, Phys. Lett. A 101, 134. 
4138. GAS TEMPERATURE DETERMINATION FROM DOPPLER-BROADENED SPECTRAL LINES WITH SELF-ABSORPTION. Behnke J. F., Scheibner H., Timmermans C. J., Physica C (Amsterdam) 124, 85.

4139. LINE SHAPES OF ATOMIC HYDROGEN IN HOLLOW-CATHODE DISCHARGES. Benesch W., Li E., Opt. Lett. 9, 338.

4140. THE IMPACT BROADENING OF THE FIRST POTASSIUM RESONANCE LINES BY RUBIDIUM ATOMS. Beuc R., Movre M., Vadla C., J. Phys. B 17, 1845.

4141. THEORY OF COLLISION-INDUCED TRANSLATION-ROTATION SPECTRA: $\mathrm{H}_{2}$-He. Birnbaum G., Chu S.-I, Dalgarno A., Frommhold L., Wright E. L., Phys. Rev. A 29, 595.

4142. STATIC AND DYNAMIC SHIFTS OF SPECTRAL LINES. Boercker D. B., Iglesias C. A., Phys. Rev. A 30, 2771.

4143. ACTIVE LASER MEDIA BASED ON A RECOMBINING PLASMA OF MULTIPLY CHARGED IONS. Boiko V. A., Bunkin F. V., Derzhiev V. I., Yakovlenko S. I., Bull. Acad. Sci (USSR), Phys. Ser. 48, 165.

4144. Hg-Ar AND $\mathrm{Hg}-\mathrm{Kr}$ INTERACTION POTENTIALS FROM TEMPERATURE-DEPENDENT ABSORPTION SPECTRA AROUND $1850 \AA$. Bousquet C., Bras N., Majdi Y., J. Phys. B 17, 1831 .

4145. ENHANCED QUENCHING AT REDUCED INTERNUCLEAR SEPARATIONS OF XENON COLLISION PAIRS. Böwering N., Raymond T. D., Keto J. W., Phys. Rev. Lett. 52, 1880.

4146. THEORETICAL INSTRUMENT FUNCTION OF A PHOTOIONIZATION EMISSION SPECTROMETER. Butikov E. I., Tumarkin Ya. N., Osipova E. A., Opt. Spectrosc. (USSR) 57, 202.

4147. DECONVOLUTION, DERIVATION, AND SMOOTHING OF SPECTRA USING FOURIER TRANSFORMS. Cameron D. G., Moffatt D. J., J. Test. Eval. 12, 78.

4148. TWO-CHANNEL TECHNIQUE FOR STARK MEASUREMENTS OF ELECTRON DENSITY WITHIN A LASER-PRODUCED SODIUM PLASMA. Cappelli M. A., Measures R. M., App1. Opt. 23,2107 .

4149. EXACT COMPLEX LINE SHAPES OF ATOMIC RESONANCE. Chan L. K. P., Appl. Opt. 23,368 . 
4150. TABLES FOR DIRECT DETERMINATION OF SPECTRAL LINE PARAMETERS, FROM SPECTROMETRIC DATA-II. INTERMEDIATE VOIGT BROADENING. Claude M. L., J. Quant. Spectrosc. Radiat. Transfer 32, 17.

4151. IMPROVED PSEUDOPOTENTIAL CALCULATIONS OF THE ADIABATIC POTENTIALS AND OSCILLATOR STRENGTHS OF T1-HEAVY NOBLE GAS SYSTEMS. Czuchaj E., Sienkiewicz J., Z. Naturforsch., Teil A 39, 513.

4152. PSEUDOPOTENTIAL CALCULATION OF THE ADIABATIC POTENTIALS AND OSCILLATOR STRENGTHS OF CADMIUM-RARE-GAS PAIRS. Czuchaj E., Sienkiewicz J., J. Phys. B 17, 2251.

4153. ATOMIC PHYSICS FOR BEAM-TARGET INTERACTIONS. Deutsch C., Laser Part. Beams 2, 449 .

4154. ELECTRON IMPACT LINE WIDTHS OF THE RESONANCE LINES OF Be-LIKE IONS. Dimitrijevic M. S., Astron. Astrophys. 131, 327.

4155. THE TRAJECTORY EFFECT IN CALCULATIONS OF THE PHASESHIFT FOR BINARY COLLISIONS AND BROADENING OF NEUTRAL ATOM LINES. Dimitrijevic M. S., J. Phys. B 17, L283.

4156. STARK BROADENING OF NEUTRAL HELIUM LINES. Dimitrijevic M. S., Sahal-Bréchot S., J. Quant. Spectrosc. Radiat. Transfer 31, 301.

4157. ON THE DEPENDENCE OF STARK WIDTH AND SHIFT ON THE IONIZATION POTENTIAL. Dimitrijevic M. S., Konjevic N., Z. Naturforsch., Teil A 39, 553.

4158. STARK BROADENING OF NEUTRAL HELIUM LINES OF ASTROPHYSICAL INTEREST. REGULARITIES WITHIN SPECTRAL SERIES. Dimitrijevic M. S., Sahal-Bréchot S., Astron. Astrophys. 136, 289.

4159. A SIMPLE ONE PER CENT APPROXIMATION OF THE VOIGT FUNCTION. Dobrichev V., Dok1. Bolg. Akad. Nauk 37, 991.

4160. INSTRUMENT FUNCTION OF A FOURIER SPECTROMETER BASED ON A TRANSVERSE BEAM-SPLITTING INTERFEROMETER. Dubkov V. I., Opt. Spectrosc. (USSR) 57 , 557.

4161. COLLISION CROSS SECTIONS FOR THE NOBLE-GAS BROADENING OF THE Cs 6S-7P DOUBLET USING PHOTON ECHOES. Durrant A. V., Manners J., J. Phys. B 17, L701. 
4162. PHOTON ECHO RELAXATION IN CAESIUM PERTURBED BY NOBLE GASES. Durrant A. V., Manners J., Opt. Commun. 49, 293.

4163. PRESSURE BROADENING AND PRESSURE SHIFT OF THE $410 \mathrm{~nm}$ INDIUM LINE PERTURBED BY FOREIGN GASES. Eberz J., Huber G., Küh1 T., U1m G., J. Phys. B 17,3075 .

4164. EFFECT OF LIGHT SHIFTS ON THE ACCURACY OF OPTICALLY PUMPED CESIUM ATOMIC-BEAM FREQUENCY STANDARDS. Egorov V. K., Maslov V. A., Sov. Phys.--Tech. Phys. 29, 334.

4165. AN EVALUATION OF THE POSSIBILITY OF STUDYING FLARE PLASMA TURBULENCE USING SATELLITES OF He I LINE FORBIDDEN COMPONENTS. Firstova N. M., Sol. Phys. 90, 269.

4166. SHIFT OF THE He II Pa LINE IN HIGH DENSITY PLASMAS. Fleurier C., Le Gall P., J. Phys. B 17, 4311.

4167. POLARIZATION LINE SHAPE OF BALMER- $\beta$ FROM ELECTRON IMPACT DISSOCIATION OF $\mathrm{H}_{2}$. Freund R. S., Donohue D. E., Fisanick G. J., J. Chem. Phys. 80, 1754.

4168. CORRECTING MEASURED LINE HALF-WIDTHS. Fridovich B., J. Mol. Spectrosc. $105,53$.

4169. LINESHAPE IN COLLISION-INDUCED ABSORPTION. MORI THEORY. Gburski Z., Gray C. G., Sullivan D. E., Chem. Phys. Lett. 106, 55.

4170. SEARCH FOR PLASMA SHIFTS OF C VI, N VII, AND O VIII RESONANCE LINES. Goldsmith S., Griem H. R., Cohen L., Phys. Rev. A 30, 2775.

4171. ANALYSIS OF A SPECTRUM OF TWO LORENTZIAN OR GAUSSIAN LINES BY MEASURING $\mathrm{n}$ ${ }^{(2)}$ (T). Gonzalez F., Rebolledo M. A., Cagigal M. P., App1. Opt. 23, 3024.

4172. DETERMINATION OF ELECTRON DENSITY IN AN ATOMIC PLASMA BY LEAST-SQUARES FIT TO THE STARK PROFILE. Goode S. R., Deavor J. P., Spectrochim. Acta, Part B 39, 813.

4173. BROADENING OF OPTICAL LINES ORIGINATING FROM RYDBERG STATES: A SIMPLE MODEL. Gounand F., Szudy J., Hugon M., Sayer B., Fournier P. R., Ann. Phys. (Paris) 9, 597. 
4174. TWO-PHOTON ABSORPTION METHOD FOR THE STUDY OF COLLISIONAL RELAXATION OF ATOMS IN A PERTURBER BATH. Granier R., Charton G., Granier L., J. Quant. Spectrosc. Radiat. Transfer 31, 379.

4175. THE FULL VOIGT PROFILE AND COLLISION TIME ASYMMETRY FOR PROFILES OF CALCIUM $442.7 \mathrm{~nm}$ PERTURBED BY KRYPTON. Harris M., Lewis E. L., McHugh D., Shannon I., J. Phys. B 17, L661.

4176. OPTICAL PROPERTIES OF AN ISOLATED RESONANCE LINE WITH HIGH DENSITY SELF-BROADENING. Heering W., J. Quant. Spectrosc. Radiat. Transfer 32, 81.

4177. ELECTRIC MICROFIELD DISTRIBUTION IN MULTICOMPONENT PLASMAS. Held B., J. Phys. (Paris) 45, 1731.

4178. LOW-FREQUENCY ELECTRIC MICROFIELD IN DENSE AND HOT MULTICOMPONENT PLASMAS. Held B., Deutsch C., Gombert M.-M., Phys. Rev. A29, 880.

4179. STARK BROADENING OF HYDROGENIC HEAVY IONS IN DENSE INERTIAL-CONFINEMENT FUSION PLASMAS. Held B., Deutsch C., Gombert M.-M., Phys. Rev. A 29, 896.

4180. STUDIES OF EMISSION-LINE PROFILES FROM ION-EXCITED NEON GAS TARGETS. Heselius S.-J., Lindblom P., Nyman E. M., Solin 0., Int. J. Appl. Radiat. Isot. 35,977 .

4181. LINE SHIFT IN NEUTRAL XENON AT HIGH ELECTRON DENSITIES. HesS H., Hitzschke L., Metzke E., Niepraschk R., Wirsig M., "Symposium on Physics of Ionized Gases," 453-456 (1984).

4182. POTASSIUM-SEEDED WALL-STABILIZED ARC SOURCE FOR STARK BROADENING STUDIES. Hohimer J. P., Rev. Sci. Instrum. 55, 1410.

4183. STARK BROADENING OF POTASSIUM ns-4p AND nd-4p LINES IN A WALL-STABILIZED ARC. Hohimer J. P., Phys. Rev. A 30, 1449.

4184. MEASUREMENT OF THE SHIFT OF RYDBERG ENERGY LEVELS INDUCED BY BLACKBODY RADIATION. Hollberg L., Hall J. L., Phys. Rev. Lett. 53, 230.

4185. SHIFTS OF SPECTRAL LINES IN A PLASMA. Iglesias C. A., Phys. Rev. A 29, 1366. 
4186. ELECTRIC MICROFIELD DISTRIBUTIONS IN MULTICOMPONENT PLASMAS. Iglesias C. A., Lebowitz J. L., Phys. Rev. A 30, 2001.

4187. EFFECTS OF INDIVIDUAL LINE SHAPES ON COMPOSITE PROFILES AND LINE SERIES. Iglesias C. A., Lee R. W., Hooper C. F., Whitten B. L., J. Quant. Spectrosc. Radiat. Transfer 32, 241.

4188. DISPLACEMENT AND DEFORMATION OF ATOMIC RADIATION LINES IN A LASER-RADIATION FIELD. MANY-PHOTON PROCESSES. Ivanov L. N., Bull. Acad. Sci. USSR, Phys. Ser. 48, 24.

4189. ASYMMETRY PATTERNS OF PLASMA-BROADENED ISOLATED LINES: C I. Jones D. W., Wiese W. L., Phys. Rev. A 30, 2602.

4190. NATURAL RADIATIVE LIFETIMES AND STARK-SHIFT PARAMETERS IN THE $4 \mathrm{p}^{2}$ CONFIGURATION IN Ca I. Jönsson G., Levinson C., Svanberg S., Phys. Scr. 30,65 .

4191. NONADIABATIC THEORY OF ATOMIC LINE BROADENING: FINAL-STATE DISTRIBUTIONS AND THE POLARIZATION OF REDISTRIBUTED RADIATION. Julienne P. S., Mies F. H., Phys. Rev. A 30, 831.

4192. OBSERVATION OF SPECTRAL LINE PROFILES EMITTED BY AN INDUCTIVELY COUPLED PLASMA-I. ON THE WAVELENGTH SHIFT OF SPECTRAL LINES. Kato K., Fukushima H., Nakajima T., Spectrochim. Acta., Part B, 39, 979.

4193. X-RAY SPECTROSCOPY FROM VARIABLE Z LASER-PRODUCED PLASMAS. Kauffman R. L., Lee R. W., Matthews D. L., Kilkenny J. D., J. Quant. Spectrosc. Radiat. Transfer 32, 335.

4194. BROADENING AND SHIFT OF RYDBERG LEVELS BY ELASTIC COLLISIONS WITH RARE-GAS ATOMS. Kaulakys B. P., J. Phys. B 17, 4485.

4195. EFFECTS OF ATOMIC COLLISIONS ON RADIATION LINE WIDTH. Klivadenko V. A., Moscow Univ. Phys. Bull. 39, No. 6, 84.

4196. EXPERIMENTAL STARK WIDTHS AND SHIFTS FOR SPECTRAL LINES OF POSITIVE IONS (A CRITICAL REVIEW AND TABULATION OF SELECTED DATA FOR THE PERIOD 1976 TO 1982). Konjevic N., Dimitrijevic M. S., Wiese W. L., J. Phys. Chem. Ref. Data 13,649 . 
4197. EXPERIMENTAL STARK WIDTHS AND SHIFTS FOR SPECTRAL LINES OF NEUTRAL ATOMS (A CRITICAL REVIEW OF SELECTED DATA FOR THE PERIOD 1976 TO 1982).

Konjevic N., Dimitrijevic M. S., Wiese W. L., J. Phys. Chem. Ref. Data $13,619$.

4198. ANALYTIC REPRESENTATION OF THE COMPLETE SPECTRAL LINE PROFILE IN THE ADIABATIC THEORY OF PRESSURE BROADENING. Kutznetsov M. N., Opt.

Spectrosc. (USSR) 57, 251.

4199. THE EFFECT OF PRESSURE BROADENING AND LINE SHIFT ON THE DETERMINATION OF LEAD ISOTOPIC RATIOS BY ATOMIC ABSORPTION AND FLUORESCENCE SPECTROSCOPY. Larkins P. L., Spectrochim. Acta, Part B 39, 1365.

4200. PROFile DECONVOLUTION. Law J., Hogan D., Nucl. Instrum. Methods Phys. Res., Sect. B 233, 67.

4201. DECONVOLUTiOn. Law J., Jones M. C., Nucl. Instrum. Methods Phys. Res., Sect. A 225, 127.

4202. INVESTIGATION OF STARK BROADENING OF NONLINEAR THREE-LEVEL RESONANCES ON BOUND Ar II TRANSITIONS. Lebedeva V. V., Odintsov A. I., Glavatskikh N. A., Grin' L. E., Shul'ga A. G., J. Appl. Spectrosc. (USSR) 41, 991.

4203. ELECTRON DENSITY FROM RESOLVED STARK PROFILES IN ABLATION PLASMAS. Lee R. W., Kilkenny J. D., Kauffman R. L., Matthews D. L., J. Quant. Spectrosc. Radiat. Transfer 31, 83.

4204. SPECTRA-A MODEL FOR K-SHELL SPECTROSCOPY. Lee R. W., Whitten B. L., Stout II R.E., J. Quant. Spectrosc. Radiat. Transfer 32, 91.

4205. CO-INDUCED PRESSURE BROADENING AND SHIFT OF THE $535.0 \mathrm{~nm}$ THALLIUM LINE. Lisicki E., Bielski A., Bilinska D., Szudy J., Wolnikowski J., Acta Phys. Pol. A 65, 361 .

4206. ON THE APPLICABILITY OF UNIFIED THEORY FOR IONS AND ELECTRONS IN THE STUDY OF STARK BROADENING OF HYDROGEN LINES. Mathys G., Bull. Soc. R. Sci. Liege 53, 193.(Fr.)

4207. UNIFIED THEORY CALCULATIONS OF STARK-BROADENED HYDROGEN LINES IN THE PRESENCE OF A MAGNETIC FIELD. Mathys G., Astron. Astrophys. 139, 196. 
4208. A THEORY OF HYDROGEN LINE BROADENING IN THE PRESENCE OF A MAGNETIC FIELD ACCOUNTING FOR ION DYNAMICS. Mathys G., Astron. Astrophys. 141, 248.

4209. EFFECTS OF ION MOTION ON STARK PROFILES OF OVERLAPPING NEUTRAL HELIUM LINES. Mazure A., Nollez G., Ann. Phys. (Paris) 9, 675.

4210. INFLUENCE OF THE DISPERSIVE SYSTEM IN INDUCTIVELY COUPLED PLASMA ATOMIC EMISSION SPECTROMETRY. McLaren J. W., Mermet J. M., Spectrochim. Acta, Part B 39, 1307.

4211. STARK EFFECT OF ATOMIC SODIUM MEASURED IN A HOLLOW CATHODE PLASMA BY DOPPLER-FREE SPECTROSCOPY. Moreno F., Alvarez J. M., Amaré J. C., Bernabeu E., J. Appl. Phys. 56, 1939.

4212. CALCULATION OF THE VOIGT PROFILE, WITH APPLICATION TO INFRARED LINES OF THE Stratosphere AND MESOSPhERE. Muller C., Bull. Cl. Sci. Acad. R. Belg. $70,675 .(\mathrm{Fr}$,

4213. TREATMENT OF INTERSHELL CORRELATION EFFECTS IN AB INITIO CALCULATIONS BY USE OF CORE POLARIZATION POTENTIALS. METHOD AND APPLICATION TO ALKALI AND ALKALINE EARTH ATOMS. Müller W., Flesch J., Meyer W., J. Chem. Phys. 80, 3297.

4214. HIGHLY CHARGED ION LINE SHIFT IN DENSE PLASMAS. Nguyen Hoe, Koenig M., Coulaud G., Phys. Lett. A 106, 34.

4215. BROADENING OF SPECTRAL ABSORPTION LINES OF ATOMIC POTASSIUM UNDER THE ACTION OF LASER RADIATION. Ninoyan Zh. O., Sapondzhyan S. O., Sarkisyan G. S., Sov. J. Quantum Electron. 14, 1053.

4216. PLASMA SPECTROSCOPY WITH QUASIMONOCHROMATIC ELECTRIC FIELDS. Oks E. A., Sov. Phys.--Dok1. 29, 224.

4217. DESCRIPTION OF WING BROADENING OF HYDROGEN SPECTRAL LINES. Pargamanik L. E., Ginzburg M. D., Ukr. Fiz. Zh. 29, 514.

4218. UNIFIED THEORIES OF THE PRESSURE BROADENING AND SHIFT OF SPECTRAL LINES: I. GENERAL FORMULATION FOR MULTIPOLE INTERACTIONS. Peach G., J. Phys. B $17,2599$. 
4219. UNIVERSAL FORMULA FOR THE SPECTRAL LINE PROFIlE. Pestov E. G., Sov. J. Quantum Electron. 14, 2 .

4220. ON THE QUADRUPOLE CONTRIBUTIONS TO ELECTRON BROADENING OF SPECTRAL LINES. Pfenning H., Mwana Umbella I. S. K., J. Quant. Spectrosc. Radiat.

Transfer $31,247$.

4221. EXPERIMENTAL STUDY OF THE STARK BROADENED HELIUM ION LINES He II 121.5, 164.0 AND 468.6 nm. Piel A., Slupek J., Z. Naturforsch., Teil A 39, 1041.

4222. STARK BROADENING MEASUREMENTS OF SOME N II AND N III LINES. Purcell S. T., Barnard A. J., J. Quant. Spectrosc. Radiat. Transfer 32, 205.

4223. STARK WIDTHS AND SHIFTS OF Co I SPECTRAL LINES. Puric J., Cuk M., Rathore B. A., Lakicevic I. S., Phys. Lett. A 106, 374.

4224. MEASUREMENT OF THE STARK WIDTHS AND SHIFTS OF Cr II $4 \mathrm{~s}{ }^{4} \mathrm{D}-4 \mathrm{p}{ }^{4} \mathrm{~F}^{0}$ SPECTRAL LINES. Rathore B. A., Lakicevic I. S., Cuk M., Puric J., Phys. Lett. A $100,31$.

4225. STARK-BROADENING MEASUREMENTS OF SINGLY IONIZED XENON. Richou J., Manola S., Lebrun J. L., Lesage A., Phys. Rev. A 29, 3181.

4226. ELECTRON CONCENTRATION MEASUREMENT IN THE HIGH VOLTAGE SPARK USING STARK BROADENING OF H $\beta$ EMISSION. Scheeline A., Kamla G. J., Zoellner M. J., Spectrochim. Acta, Part B 39, 677.

4227. OPTICAL COLLISIONS AND REDISTRIBUTION IN THE PRESENCE OF AN INTENSE DRIVING FIELD. Schuller F., Ann. Phys. (Paris) 9, 609.

4228. ANALYTIC EXPRESSIONS FOR FLUORESCENCE SPECTRA AND OPTICAL COLLISION RATES OF COLLISIONALLY PERTURBED ATOMS IN A STRONG DRIVING FIELD. Schuller F., Nienhuis G., Can. J. Phys. 62, 183.

4229. LEVEL AND LINE BROADENING FOR THOMAS-FERMI ATOMS AT FINITE TEMPERATURE. Shalitin D., Stein J., Ron A., Phys. Rev. A 29, 2789.

4230. OPTICALLY THICK MODEL FOR RADIATIVE AND COLLISIONAL EFFECTS IN NONEQUILIBRIUM ARGON PLASMA FLOWS IN A CIRCULAR TUBE. Shirai H., Tabei K. , Koaizawa H., Bul1. JSME 27, 1414. 
4231. HIGH-PRESSURE NOBLE GAS BROADENING OF THE CS RESONANCE LINES. Siegling F., Niemax K., Z. Naturforsch., Teil A 39, 455.

4232. LOW-PRESSURE NOBLE GAS BROADENING OF THE Cs RESONANCE LINES. Siegling F., Niemax K., Z. Naturforsch., Teil A 39, 447.

4233. STARK BROADENING IN RADIO RECOMBINATION LINES TOWARDS THE ORION NEBULA. Smirnov G. T., Sorochenko R. L., Pankonin V., Astron. Astrophys. 135, 116.

4234. DISCUSSION OF THE CONDITIONAL-PROBABILITY FUNCTION FOR ELECTRIC FIELDS IN A Plasma. Smith E. W., Stamm R., Cooper J., Phys. Rev. A 30, 454.

4235. ION-DYNAMICS EFFECT ON HYDROGENIC STARK PROFILES IN HOT AND DENSE PLASMAS. Stamm R., Botzanowski Y., Kaftandjian V. P., Talin B., Smith E. W., Phys. Rev. Lett. 52, 2217; 54, 2170 (1985).

4236. STUDY OF HYDROGEN STARK PROFILES BY MEANS OF COMPUTER SIMULATION. Stamm R., Smith E. W., Talin B., Phys. Rev. A 30, 2039.

4237. COMPUTER SIMULATION TECHNIQUE FOR PLASMAS. Stamm R., Smith E. W., Phys. Rev. A 30, 450 .

4238. MICROFIELD SIMULATION APPLIED TO THE CALCULATION OF STARK PROFILES. Stamm R., Talin B., Ann. Phys. (Paris) 9, 687.

4239. STARK BROADENING OF THE H $\alpha$ LINE OF HYDROGEN AT LOW DENSITIES: QUANTAL AND SEMICLASSICAL RESULTS. Stehlé C., Feautrier N., J. Phys. B 17, 1477.

4240. HYDROGEN LINE PROFILES AT LOW DENSITIES. Stehlé C., Feautrier N., Ann. Phys. (Paris) 9, 697.

4241. VELOCITY CHANGING COLLISIONS IN SATURATION ABSORPTION OF U. Tenenbaum J., Miron E., Lavi S., Liran J., Strauss M., Oreg J., Erez G., J. Phys. B 16, 4543 .

4242. STUDY OF THE BALMER BETA CORE IN A PULSED PlASMA. Torres F., Gigosos M. A., Mar S., J. Quant. Spectrosc. Radiat. Transfer 31, 265.

4243. BROADENING OF SPEGTRAL LINES OF IONIZED ATOMS IN A CONSTANT MAGNETIC FIELD. Tuganov V. F., Sov. Phys.--JETP 60, 225. 
4244. OSCILLATOR STRENGTHS AND RARE-GAS-INDUCED BROADENING OF THE PRINCIPAL SERIES LINES OF Ba. Ueda K., Hamaguchi Y., Fujimoto T., Fukuda K., J. Phys. Soc. Jpn 53, 2501.

4245. THE FAR-WING BROADENING OF THE $\mathrm{Na} D$ LINES BY $\mathrm{K}, \mathrm{Rb}$ AND Cs AND THE ELECTROSTATIC INTERACTION POTENTIALS OF THE NaK, NaRb AND NaCs MOLECULES. Vadla C., Niemax K., Z. Phys. A 315, 263.

4246. GLOBAL THEORY OF SPECTRAL LINESHAPES IN THE WEAK-DENSITY LIMIT. Vallee 0., Picart J., Tran Minh N., J. Phys. B 17, L565.

4247. DETERMINATION OF SPECTRAL LINE WIDTH BY RECORDING THE DERIVATIVE OF THE TRANSMISSION SPECTRUM. Vasilevskii K. P., Kotylev V. N., Borisova N. F., Gershun M. A., Opt. Spectrosc. (USSR) 57, 671.

4248. THE SHAPE OF EMISSION LINES FROM A SPATIALLY INHOMOGENEOUS GAS CONTAINING MACROSCOPIC PARTICLES. Vasilieva I. A., J. Quant. Spectrosc. Radiat. Transfer 31,323 .

4249. EXPERIMENTAL INVESTIGATIONS OF BROADENING PARAMETERS OF He I $2{ }^{3} \mathrm{P}-4^{3} \mathrm{D}$, $4^{3} \mathrm{~F}, \lambda=447.15 \mathrm{~nm}$ LINE IN A LASER PRODUCED PLASMA. Vujicic B. T. Cirkovic L. M., Fizika (Zagreb) 16, 201.

4250. COLLISIONAL LINE BROADENING DUE TO VAN DER WAALS POTENTIALS. Walkup R., Stewart B., Pritchard D. E., Phys. Rev. A 29, 169.

4251. STARK BROADENING IN NON-LTE STELLAR ATMOSPHERES: EFFECTS ON OCCUPATION NUMBERS AND LINE PROFILES. Werner K., Astron. Astrophys. 139, 237.

4252. ELECTRON DENSITY DETERMINATION IN ARGON CESIUM MHD-PLASMAS. Wetzer J. M., Physica C (Amsterdam) 123, 247.

4253. FULL COULOMB CALCULATION OF STARK BROADENING IN LASER-PRODUCED PLASMAS. Woltz L. A., Hooper C. F. Jr., Phys. Rev. A 30, 468.

4254. EFFECTS OF COLLISIONAL NARROWING AND LINE PARAMETERS ON ATMOSPHERIC COMPOSITION MEASUREMENTS. Ying-Jian W., J. Quant. Spectrosc. Radiat. Transfer 32, 305 . 
4255. LINE PROFILES OF THE $\mathrm{P}_{\alpha}$ AND $\mathrm{P}_{\beta}$ TRANSITIONS IN HE II AND BROADENING OF $\mathrm{C}$ IV LINES AT HIGH ELECTRON DENSITIES. Ackermann U., Finken K. H., Musielok J., Phys. Rev. A 31, 2597.

4256. PROFILE OF THE L LINE OF HYDROGEN-LIKE IONS IN A DENSE PLASMA WITH ALLOWANCE FOR THE FINE STRUCTURE AND THE LAMB SHIFT. Akhmedov E. Kh., Godunov A. L., Zemtsov Yu. K., Makhrov V. A., Starostin A. N., Taran M. D., Sov. Phys.--JETP 62, 266.

4257. X-RAY SPECTROSCOPIC STUDIES OF THE ELECTRONIC DENSITY AND TEMPERATURE PROFILES IN THE TRANSPORT REGION OF 0.53 - and $0.26-\mu \mathrm{m}$ LASER PLASMAS. Alaterre P., Chenais-Popovics C., Audebert P., Geindre J. P., Gauthier J. C., Phys. Rev. A 32, 324 .

4258. TWO-PHOTON COLLISIONAL REDISTRIBUTION OF RADIATION. Alber G., "Lecture Notes in Physics-Fundamentals of Laser Interactions," No. 229, 92-108 (Ed. F. Ehlotzky, Springer-Verlag, Berlin, 1985).

4259. TWO-PHOTON COLLISIONAL REDISTRIBUTION OF RADIATION. Alber G., Cooper J., Phys. Rev. A 31, 3644.

4260. INTENSITY EFFECTS IN TWO-PHOTON COLLISIONAL REDISTRIBUTION OF RADIATION. Alber G., Cooper J., Phys. Rev. A 32, 2186.

4261. RELAXATION OF THE ORIENTATION AND ALIGNMENT OF THALLIUM ATOMS IN A BUFFER GAS. Aleksandrov E. B., Popov V. I., Yakovson N. N., Opt. Spectrosc. (USSR) $58,307$.

4262. COLLISIONAL REDISTRIBUTION OF CIRCULARLY POLARIZED LIGHT IN BARIUM PERTURBED BY ARGON. Alford W. J., Andersen N., Belsley M., Cooper J., Warrington D. M., Burnett K., Phys. Rev. A 31, 3012.

4263. PHYSICAL INTERPRETATION OF LINE PROFILES USING SQUARE-WELL INTERACTION. Allard N. F., Biraud Y. G., "Spectral Line Shapes," Vo1. 3, 615-642 (Ed. F. Rostas, Walter de Gruyter \& Co., New York, 1985).

4264. AN ANALYTIC VOIGT PROFILE ESCAPE PROBABILITY APPROXIMATION. Apruzese J. P., J. Quant. Spectrosc. Radiat. Transfer 34, 447. 
4265. COMMENT ON "IC T-DYNAMICS EFFECT ON HYDROGENIC STARK PROFILES IN HOT AND DENSE Plasmas ."Apruzese J. P., Kepple P. C., Davis J., Griem H. R., Cauble R., Phys. Rev. Lett. 54, 2167.

4266. SATURATION BEHAVIOR OF BALMER-LINE FLUORESCENCES IN A HYDROGEN PLASMA. Arata Y., Miyake S., Matsuoka H., Jpn. J. Appl. Phys. 24, 1351.

4267. EFFECTS OF AN ARBITRARY LASER LINESHAPE ON FLUORESCENCE RADIATION, REDISTRIBUTED BY COLLISIONS. Arnoldus H. F., Nienhuis G., J. Phys. B 18, 1109.

4268. CALCULATION OF THE PROFILE OF THE LYMAN- $\alpha$ LINE IN AN ARGON PLASMA. Bacchus-Montabone1 M. C., J. Phys. B 18, L363.

4269. INVESTIGATIONS OF $\mathrm{Ar}^{+}-\mathrm{H}$ SATELLITE FORMATION IN THE LYMAN- $\alpha$ LINE WINGS. Baldwin K. G. H., Burgess D. D., Grützmacher K., J. Phys. B 18, 217.

4270. BROAdENING OF DiELECTRONIC SATELlite Lines IN DENSE Plasmas. Banon J. M., Koenig M., Nguyen Hoe, J. Phys. B 18, 4195.

4271. IMPACT BROADENING AND SHIFTS FOR 6 sns ${ }^{1} \mathrm{~S}_{0}$ and 6 snd ${ }^{1} \mathrm{D}_{2}$ SERIES OF BARIUM. Bathia K. S., Bruce D. M., Duley W. W., Opt. Commun. 53, 302.

4272. OPTOGALVANIC NONLINEAR HANLE EFFECT BY A SINGLE FREQUENCY LASER: A QUANTITATIVE ANALYSIS. Beverini N., Ernst K., Inguscio M., Strumia F., Appl. Phys. B 37, 17.

4273. LOW PRESSURE BROADENING AND SHIFT OF THE $3 p^{5} 4 p-3 p^{5} 6 s$ ARGON SPECTRAL LINES PERTURBED BY He, Ne, and Ar. Bielski A., Wawrzynski J., Wolnikowski. J., Acta. Phys. Pol. A 67, 621.

4274. VISIBLE AND NEAR-INFRARED COLLISIONAL SATELLITES OF ATOMIC D-LINES IN ALKALI SYSTEMS. Bieniek R. J., "Spectral Line Shapes," Vol. 3, 647-648 (Ed. F. Rostas, Walter de Gruyter \& Co., New York, 1985).

4275. NORMALIZED LINE SHAPES FOR FAR-WING CONTINUUM SPECTRA: THE Rb-Xe SATELlite BAND. Bieniek R. J., Phys. Rev. A 32, 3150.

4276. TEMPERATURE DEPENDENGE OF THE WIDTH AND SHIFT OF THE NEON $540.06 \mathrm{~nm}$ LINE PERTURBED BY Ne AND He. Bobkowski R., Bielski A., Lisicki E., Szudy J., Wolnikowski J., Act. Phys. Pol. A 67, 601. 
4277. SOME GOMMENTS ON THE DETERMINATION OF PLASMA PARAMETERS FROM THE SPECTRAL LINE PROFILE REGISTERED BY MEANS OF THE FABRY-PEROT INTERFEROMETER. Brablec A., Stastny F., Acta Phys. Slov. 35, 162.

4278. THE H $\beta$-LINE-PROFILE IN AN OPTICAL DISCHARGE AT HIGH ELECTRON DENSITIES. Carlhoff C., Krametz E., Schäfer J. H., Schüller D., Uhlenbusch J., "Proc. 17th Int. Conf. Phenom. Ionized Gases," 972-974 (Budapest, 1985).

4279. SPATIAL PROFILES OF ELECTRON DENSITY IN THE INDUCTIVELY COUPLED PLASMA. Caughlin B. L., Blades M. W., Spectrochim. Acta, Part B 40, 987.

4280. SYNTHESIS OF EMISSION LINE PROFILES FROM FREE-BURNING ARCS. Cram L. E., J. Quant. Spectrosc. Radiat. Transfer 34, 353.

4281. USE OF THE $447 \mathrm{~nm}$ He I LINE TO DETERMINE ELECTRON CONCENTRATIONS. Czernichowski A., Chapelle J., J. Quant. Spectrosc. Radiat. Transfer 33, 427.

4282. EXPERIMENTAL DETERMINATION OF THE STARK WIDTHS OF S II LINES.

Czernichowski A., Chapelle J., "Spectral Line Shapes," Vol. 3, 49-50 (Ed. F. Rostas, Walter de Gruyter \& Co., New York, 1985).

4283. BOLTZMANN-LORENTZ MODEL OF COLLISIONAL BROADENING OF SPECTRA. Dattagupta S., Turski L. A., Phys. Rev. A 32, 1439.

4284. OPACITY EFFECTS ON HYDROGENLIKE X-RAY LINES EMITTED FROM LASER-DRIVEN IMPLOSIONS. Delamater N. D., Hooper G. F. Jr., Joyce R. F., Woltz L. A., Ceglio N. M., Kauffman R. L., Lee R. W., Richardson M. C., Phys. Rev. A $31,2460$.

4285. TEMPERATURE DEPENDENCE OF THE EDGE OF THE SPECTRAL LINE IN CLASSICAL ATOMIC MOTION. Devdariani A. Z., Sebyakin Yu. N., J. Appl. Spectrosc. (USSR) 42, 22.

4286. BROADENING AND SHIFT OF RESONANCE LINES OF SECOND-GROUP ATOMS BY LIGHT INERT GASES: INTERACTION POTENTIALS. Devdariani A. Z., Ponomarev Ya. I., Sebyakin Yu. N., Opt. Spectrosc. (USSR) 59, 26.

4287. COMPARISON OF MEASURED AND CALCULATED STARK BROADENING PARAMETERS FOR NEUTRAL-HELIUM LINES. Dimitrijevic M. S., Sahal-Bréchot S., Phys. Rev. A 31,316 . 
4288. ASTROPHYSICAL SIGNIFICANCE OF SPECTRAL LINE SHAPES INVESTIGATION.

Dimitrijevic M. S., Publ. Obs. Astron. Belgrade No. 33, 11.

4289. DEPENDENCE OF STARK WIDTHS AND SHIFTS ON THE IONIZATION POTENTIAL: $\mathrm{np}^{\mathrm{k}-1}$ $(n+1) s-n p^{k}$ RESONANCE TRANSITIONS. Dimitrijevic M. S., Astron.

Astrophys. $145,439$.

4290. SEMIEMPIRICAL STARK SHIFTS OF ION LINES. Dimitrijevic M. S., Krsljanin V., "Proc. 17th Int. Conf. Phenom. Ionized Gases," 975-977 (Budapest, 1985).

4291. STARK BROADENING OF Na I LINES: REGULARITIES WITHIN A SPECTRAL SERIES. Dimitrijevic M. S., Sahal-Bréchot S., "Proc. 17th Int. Conf. Phenom. Ionized Gases," 978-980 (Budapest, 1985).

4292. STARK BROADENING OF NEUTRAL SODIUM LINES. Dimitrijevic M. S., Sahal-Bréchot S., J. Quant. Spectrosc. Radiat. Transfer 34, 149.

4293. VOIGT-FUNCTION EVALUATION USING A TWO-DIMENSIONAL INTERPOLATION SCHEME. Drummond J. R., Steckner M., J. Quant. Spectrosc. Radiat. Transfer 34, 517.

4294. COLLISIONAL PROCESSES INDUCED IN THE $\mathrm{n}=3$ HELIUM SUBLEVELS BY ELECTRONS IN A LOW-PRESSURE PLASMA. APPLICATION TO THE ELECTRON DENSITY MEASUREMENT. Dubreuil B., Prigent P., J. Phys. B 18, 4597.

4295. ELECTRIG FIELD DISTRIBUTIONS IN STRONGLY COUPLED PLASMAS. Dufty J. W., Boercker D. B., Iglesias G. A., Phys. Rev. A 31, 1681.

4296. MOLECULAR-DYNAMICS SIMULATION OF EFFECTS OF RELAXATION OF POLARIZATION ON ATOMIC LINE SHAPES. Evensky D. A., Sando K. M., Phys. Rev. A 31, 772.

4297. LINE WIDTH AND LINE SHAPE ANALYSIS IN THE INDUCTIVELY COUPLED PLASMA BY HIGH RESOLUTION FOURIER TRANSFORM SPECTROMETRY. Faires L. M., Palmer B. A., Brault J. W., Spectrochim. Acta, Part B 40, 135.

4298. BROADENING AND SHIFT OF $\mathrm{Cu}$ I and $\mathrm{Cu}$ II LINES IN PLASMAS. Fleurier C., Maulat C., "Proc. 17th Int. Conf. Phenom. Ionized Gases," 981-983 (Budapest, 1985). 
4299. SELF ABSORPTION OF A VOIGT-PROFILE LINE FOR NON-UNIFORM SOURCE FUNCTIONS. Fujimoto T., Nishimura Y., J. Quant. Spectrosc. Radiat. Transfer 34, 217.

4300. A THEORY FOR THE ION IMPACT BROADENING OF FINE-STRUCTURE SUBLEVELS. Gaisinsky I. M., Oks E. A., J. Phys. B 18, 1449.

4301. HYDROGEN PLASMA EMISSION AT $10^{17}-10^{18} \mathrm{~cm}^{-3}$ ELECTRON DENSITIES. Gavrilov V. E., Gavrilova T. V., Fedorova T. N., Opt. Spectrosc. (USSR) 59, 313.

4302. EFFECTS OF EMITTER MOTION ON THE L STARK PROFILES INVESTIGATED BY VARYING THE PLASMA TEMPERATURE AT CONSTANT ELECTRON DENSITY. Geisler M., Grützmacher K., Wende B., "Spectral Line Shapes," Vol. 3, 67-68 (Ed. F. Rostas, Walter de Gruyter \& Co., New York, 1985).

4303. HYDROGEN STARK PROFILES: A SIMULATION-ORIENTED MATHEMATICAL SIMPLIFICATION. Gigosos M. A., Fraile J., Torres F., Phys. Rev. A 31, 3509 .

4304. LY-alpha STARK BROADENING: AN IMPROVED IMPACT MODEL. Gigosos M. A., Torres F., "Spectral Line Shapes," Vol. 3; 75-76 (Ed. F. Rostas, Walter de Gruyter \& Co., New York, 1985).

4305. PRESSURE SHIFT IN CORE AND WINGS OF $\alpha$ AND $\beta$ BALMER LINES AND ITS RELEVANCE TO THE GRAVITATIONAL-REDSHIFT MEASUREMENTS IN WHITE DWARFS. Grabowski B., Halenka J., Madej J., "Proc. 17th Int. Conf. Phenom. Ionized Gases," 987-988 (Budapest, 1985).

4306. DIAGNOSTICS OF. A HYDROGEN PLASMA WITH AN ELECTRON DENSITY OF $10^{18} \mathrm{~cm}^{-3}$. Gravilov V. E., Gravilova T. V., Fedorova T. N., Opt. Spectrosc. (USSR) 58,755 .

4307. REPLY TO "COMMENT ON 'SHIFTS OF HYDROGEN LINES FROM ELECTRON COLLISIONS IN DENSE PLASMAS"". Griem H. R., Phys. Rev. A 32, 1908.

4308. REDSHIFTS OF THE INTENSITY PEAK OF THE $\mathrm{H}_{\alpha}$ LINE IN ARGON ARC-PLASMA. Halenka J,, "Proc. 17th Int. Conf. Phenoim. Ionized Gases," 993-995 (Budapest, 1985).

4309. PHYSICAL LINE WIDTHS OF ATOMS AND IONS IN AN INDUCTIVELY COUPLED ARGON PLASMA AND HOLLOW CATHODE LAMPS AS MEASURED BY AN. ECHELLE MONOCHROMATOR WITH WAVELENGTH MODULATION: Hasegawa T., Haraguchi H., Spectrochim. Acta, Part B 40, 123. 
4310. GOOD NEWS - BAD NEWS? STARK BROADENING AT MODERATE ELECTRON DENSITIES. Helbig V., "Spectral Line Shapes," Vol. 3, 3-33 (Ed. F. Rostas, Walter de Gruyter \& Co., New York, 1985).

4311. TEMPERATURE EFFECTS ON LOW-FREQUENCY ELECTRIC MICROFIELDS IN MULTiCOMPONENT Plasmas. Held B., Phys. Rev. A 31, 1939.

4312. DIFFRACTION AND SYMMETRY CORRECTIONS TO THE HIGH-FREQUENCY THERMAL MICROFIELD IN A DENSE ELECTRON PLASMA. Held B., Gombert M. M., Deutsch C., Phys. Rev. A 31, 921.

4313. THE BALMER ALPHA PROFILE CORRECTED FOR STRONG SELF-ABSORPTION. Hernandez J., Torres F., Mar S., Gigosos M. A., J. Quant. Spectrosc. Radiat. Transfer 33,35 .

4314. STATISTICAL PROCEDURE FOR DECONVOLUTING EXPERIMENTAL DATA. Hiragi Y., Urakawa·H. , J. Appl. Phys. 58, 5.

4315. REPLY TO "STARK BROAdENING OF POTÁSSIUM LINES". Hohimer J. P., Phys. Rev. A $32,676$.

4316. STUDY OF LINE RADIATION IN HIGH'DENSITY ARGON PLASMA. Höss P., "Proc. 17th Int. Conf. Phenom. Ionized Gases," 348-350 (Budapest, 1985).

4317. COMMENT ON "SHIFTS OF.HYDROGEN LINES FROM ELECTRON COLLISIONS IN DENSE PLASMAS:" Iglesias C. A., Boercker. D. B., Lee R. W., Phys. Rev. A 32, 1906.

4318. LOW-FREQUENCY ELECTRIC MICROFIELD .DISTRIBUTIONS IN PLASMAS. Iglesias C. A., DeWitt H. E., Lebowitz J. L., MacGowan D., Hubbard W. B., Phys. Rev. A $31,1698$.

4319. MEASUREMENTS OF ION TEMPERATURE AND DRIFT ENERGY OF HYDROGEN PLASMA BY NEUTRAL BEAM PROBE SPECTROSCOPY. I to Y., Tsukuda K., Goto S., I shimura T., J. App1. Phys. 58, 1752.

4320. TEMPERATURE DEPENDENCE OF THE COLLISIONAL SHIFTS AND BROADENING OF THE CESIUM D LINE IN HELIUM. Izotova S. L., Kalịteevskii N. I., Lekhto G. F., Frish M. S., Opt. Spectrosc. (USSR). 59, 293. 
4321. SHIFT AND BROADENING CONSTANTS OF $\mathrm{Cs}^{133} \mathrm{D}_{1}$ LINE HYPERFINE COMPONENTS IN NEON AND ARGON. Izotova S. L., Lekhto G. F., Frish M. S., Opt. Spectrosc. (USSR) 59, 136.

4322. RESOLVED LINE PROFILES OF ATOMIC OXYGEN RESONANCE LAMPS USED IN THE UPPER ATMOSPHERE. Jenkins D. B., Watkin G., Wareing D. P., Freeman G. H. C., Dickinson P. H. G., Mackinnon D. J., J. Quant. Spectrosc. Radiat. Transfer 34, 123.

4323. MEASUREMENT OF THE RELATIVISTIC DOPPLER SHIFT IN NEON. Kaivola M., Poulsen 0., Riis E., Lee S. A., Phys. Rev. Lett. 54, 255.

4324. RESONANCE BROADENING OF 794.7-AND 780.0-nm Rb I LINE. Kantor P. Ya., Mokhov A. V., Penkin N. P., Shabanova L. N., Opt. Spectrosc. (USSR) 58, 745 .

4325. PROFILE OF Rb I 421.6-AND 420.2-nm LINES IN THE PRESENCE OF INERT GASES AND PARAMETERS OF INTERATOMIC POTENTIALS. Kantor P. Ya., Penkin N. P., Shabanova L. N., Opt. Spectrosc. (USSR) 58, 136.

4326. PROFILE OF K I 769.9-AND 766.5-nm LINES ON RESONANCE BROADENING. Kantor P. Ya., Penkin N. P., Shabanova L. N., Opt. Spectrosc. (USSR) 59, 113 :

4327. BROADENING OF THE K I 769.9 AND 766.5-nm LINES BY INERT GASES. Kantor P. Ya., Penkin N. P., Shabanova L. N., Opt. Spectrosc. (USSR) 59, 151.

4328. BROADENING OF THE 404.7 AND $404.4 \mathrm{~nm}$ LINES OF K I BY INERT GASES. Kantor P. Ya., Penkin N. P., Shabanova L. N., Vestn. Leningrad. Univ., Fiz. Khim. 18, No. 3, 80 .

4329. PROFILES OF THE Rb I 794.7-and 780.0-nm LINES IN THE PRESENCE OF INERT GASES; PARAMETERS OF INTERATOMIC POTENTIALS. Kantor P. Ya., Shabanova L. N., Opt. Spectrosc. (USSR) 58, 614.

4330. LINE BROADENING IN OPTICALLY THICK GAS DISCHARGES; INFLUENCE ON PLASMA TEMFERATURE DETERMINATION. Karabourniotis D., Karras C., J. Appl. Phys. 57,4861 .

4331. OPERATING PRESSURE OF THALLIUM IN A MERCURY-THALLIUM IODIDE DISCHARGE USING THE LINE T1-5350 $\AA$. Karabourniotis D., Couris S., Karras C., J. App1. Phys. 58, 2786. 
4332. MEASUREMENT OF WIDTHS AND SHIFTS OF Xe I LINES EMITTED FROM AN ELECTRIC PULSE DISCHARGE. Kettlitz M., Radtke R., Spanke R., "Proc. 17th Int. Conf. Phenom. Ionized Gases," 999-1000 (Budapest, 1985).

4333. SHIFT AND OSCILLATOR STRENGTH OF Xe I LINES EMITTED FROM AN ELECTRIC PULSE DISCHARGE. Kettlitz M., Radtke R., Spanke R., Hitzschke L., J. Quant. Spectrosc. Radiat. Transfer 34, 275.

4334. REDISTRIBUTION OF RADIATION UNDER THE INTERFERENCE OF QUANTUM STATES. Khvostenko G. I., Chaika M. P., Opt. Spectrosc. (USSR) 59, 714.

4335. THE STATIC APPROXIMATION IN THE INTERPRETATION OF COLLISION BROADENING. Kielkopf J. F., J. Quant. Spectrosc. Radiat. Transfer 33, 267.

4336. FAR-WING ABSORPTION PROFILES OF A REACTIVE COLLISION: $\mathrm{Mg}+\mathrm{H}_{2}$. Kleiber P. D., Lyyra A. M., Sando K. M., Heneghan S. P., Stwalley W. C., Phys. Rev. Lett. 54, 2003.

4337. A DOUBLE-RESONANCE MEASUREMENT OF THE HYDROGEN BALMER-BETA LINESHAPE. Kolbe G., Burgess D. D., J. Phys. B 18, 3681.

4338. STARK BROADENING OF POTASSIUM LINES. Konjevic N., Phys. Rev. A 32, 673.

4339. STARK BROADENING OF N II LINES FROM STATES OF HIGH ORBITAL ANGULAR MOMENTUM. Konjevic N., Pittman T., "Proc. 17th Int. Conf. Phenom. Ionized Gases," 1010-1011 (Budapest, 1985).

4340. STARK BROADENING OF Br I LINES. Konjevic R., Platisa M., Konjevic N., "Spectral Line Shapes," Vol. 3, 57-58 (Ed. F. Rostas, Walter de Gruyter \& Co., New York, 1985).

4341. AN INVESTIGATION OF COLLISIONAL BROADENING OF NEON 1.15- $\mu \mathrm{m}$ LINE USING HANLE SIGNALS. Kot1ikov E. N., Perchuk O. V., Opt. Spectrosc. (USSR) 59, 557.

4342. ESTIMATED STARK WIDTHS AND SHIFTS OF SOME SINGLY CHARGED ION SPECTRAL LINES. Lakicevic I. S., Astron. Astrophys. 151, 457.

4343. SPECTROSCOPIC STARK LINE PROFILE IN A NON-HOMOGENEOUS FIELD QUASI-STATIC APPROXIMATION. Lambert D., Louis-Jacquet M., J. Phys. (Paris) 46, 379. 
4344. ANOMALOUS Cs I 5d-5f LineShAPE IN A NON-DEBYE PLASMA. Landen O. L., Winfield R. J., Lee R. W., J. Quant. Spectrosc. Radiat. Transfer 34, 177.

4345. PRODUCTION OF DENSE, COOL PLASMAS BY RESONANCE PUMPING OF SODIUM VAPOR. Landen O. L., Winfield R. J., Burgess D. D., Kilkenny J. D., Lee R. W., Phys. Rev. A 32, 2963.

4346. PRODUCTION OF DENSE, COOL PLASMAS BY MULTIPHOTON IONIZATION OF SODIUM VAPOR. Landen O. L., Winfield R. J., Phys. Rev. A 32, 2972.

4347. ATOMIC LINE PROFILE MEASUREMENTS ON HOLLOW-CATHODE AND ELECTRODELESS DISCHARGE LAMPS USING A HIGH-RESOLUTION ECHELLE MONOCHROMATOR. Larkins P. L., Spectrochim. Acta., Part B 40, 1585.

4348. ASYMMETRICAL BROADENING AND MERGING OF HYDROGENIC LINES EMITTED FROM DENSE PLASMAS. Leboucher E., Koenig M., d'Etat B., Terray L., Nguyen Hoe, "Spectral Line Shapes," Vol. 3, 249-250 (Ed. F. Rostas, Walter de Gruyter \& Co., New York, 1985).

4349. FITS FOR HYDROGENIC STARK-BROADENED LINE PROFILES FOR THE ELEMENTS CARBON TO ARGON. Lee R. W., J. Appl. Phys. 58, 612.

4350. NONTHERMAL EFFECTS ON HYDROGEN-LINE PROFILES. Lee R. W., Morgan W. L., Phys. Rev. A 32, 448 .

4351. BROADENING AND SHIFT PARAMETERS OF THE SODIUM D LINES PERTURBED BY ATOMIC HYDROGEN. Lemaire J. L., Chotin J. L., Rostas F., J. Phys. B 18, 95.

4352. DENSITY EFFECT ON THE FREQUENCY OF THE SATELLITES. CASE OF Rb-Kr. Leycuras Y., "Spectral Line Shapes," Vo1. 3, 693-694 (Ed. F. Rostas, Walter de Gruyter \& Co., New York, 1985).

4353. ALTERNATING-CURRENT STARK-EFFECT LINE SHAPES IN MULTIPHOTON IONIZATION SPECTRA. Li L., Yang B.-X., Johnson P. M., J. Opt. Soc. Am. B 2, 748.

4354. PRESSURE EFFECTS OF FOREIGN GASES ON THE $535.0 \mathrm{~nm}$ FLUORESCENCE LINE OF THALLIUM. Lisicki E., Bielski A:, Szudy J., Wolnikowski J., Z. Naturforsch., Teil A 40, 800 .

4355. REDISTRIBUTION OF RADIATION IN THE ABSENCE OF COLLISIONS. Lombardi G. G., Kelleher D. E., Cooper J., Astrophys. J. 288, 820. 
4356. HYDROGEN LINE FORMATION IN DENSE PLASMAS IN THE PRESENCE OF A MAGNETIC FIELD. Mathys G., "Progress in Stellar Spectral Line Formation Theory," 381-388 (Eds. J. E. Beckman \& L. Crivellari, D. Reidel Publ. Co., 1985).

4357. HYDROGEN LINES STARK BROADENING TABLES IN THE PRESENCE OF A MAGNETIC FIELD. Mathys G., Astron. Astrophys., Supp1. Ser. 59, 229.

4358. EXPERIMENTAL PHOSPHORUS AND SULFUR STARK WIDTHS AND SYSTEMATIC BROADENING TRENDS FOR THIRD-ROW IONS. Miller M. H., Abadie D., Lesage A., Astrophys. J. 291, 219.

4359. SIMPLE PADE APPROXIMATION FOR THE WIDTH OF A VOIGT PROFILE. Minguzzi P., Di Lieto A., J. Mol. Spectrosc. 109, 388.

4360. DETERMINATION OF ABSORPTION CROSS SECTIONS IN THE QUASISTATIC FAR WINGS OF POTASSIUM-LINES BROADENED BY MOLECULAR GASES. Mnatsakanyan A. K., Shikov V. K., Eigenson E. B., Opt. Spectrosc. (USSR) 59, 309.

4361. THE BROADENING AND SHIFT OF THE SODIUM D LINES DUE TO COLLISIONS WITH ATOMIC HYDROGEN. Monteiro T. S., Dickinson A. S., Lewis E. L., J. Phys. B $18,3499$.

4362. MEASUREMENTS OF STARK WIDTHS OF Ge I LINES. Musiol K., Pokrzywka B., Labuz S., "Proc. 17th Int. Conf. Phenom. Ionized Gases," 1025-1026 (Budapest, 1985).

4363. LASER TWO-PHOTON ABSORPTION COLLISIONAL BROADENING AND SHIFT OF THE THALLIUM $6{ }^{2} \mathrm{P}_{1 / 2}-8{ }^{2} \mathrm{P}_{1 / 2,3 / 2}$ AND $6{ }^{2} \mathrm{P}_{1 / 2}-5{ }^{2} \mathrm{~F}$ TRANSITIONS BY ARGON. Naqvi A. S., Naveedullah K., Opt. Commun. 55, 61.

4364. OPTO-GALVANIC SPECTROSCOPY OF BROADENING AND SHIFT OF TWO-PHOTON THALLIUM TRANSITIONS BY $\mathrm{N}_{2}$ AND He. Naveedullah K., Naqvi A. S., Opt. Commun. 56, 117.

4365. PRODUCTION OF LTE - PLASMAS USING A MODIFIED CAPILLARY DISCHARGE. Neger T., Jäger H., "Proc. 17th Int. Conf. Phenom. Ionized Gases," 1027-1028 (Budapest, 1985).

4366. REGULARITIES IN RARE GAS ION LINE BROADENING. Nick K. P., Helbig V., "Spectral Line Shapes," Vol. 3, 47-48 (Ed. F. Rostas, Walter de Gruyter \& Co., New York, 1985). 
4367. SUBNATURAL LINEWIDTHS IN ATOMIC SPECTROSCOPY. O'Brien D. P., Meystre P., Walther H., Adv. At. Mol. Phys. $21,1$.

4368. ABSORPTION AND EMISSION OF RADIATION IN THE REGION OF AN AVOIDED LEVEL CROSSING. O'Callaghan M. J., Gallagher A., Holstein T., Phys. Rev. A 32, 2754 .

4369. ELECTRIC MICROFIELD CALCULATIONS: AN ALL-ORDER RESUMMATION OF THE BARANGER-MOZER SERIES. Perrot F., Dharma-Wardana W. C., Physica A 134 , 231.

4370. LOCAL FIELdS IN STRONGLY COUPLED PLASMAS. Pollock E. L., Weisheit J. C., "Spectral Line Shapes," Vol. 3, 181-208 (Ed. F. Rostas, Walter de Gruyter \& Co., New York, 1985).

4371. REGULARITIES AND SYSTEMATIC TRENDS IN THE STARK BROADENING AND SHIFT PARAMETERS OF SPECTRAL LINES IN PLASMA. Puric J., Cuk M., Phys. Rev. A $32,1106$.

4372. STARK PARAMETERS DEPENDENCE ON THE UPPER LEVEL IONIZATION POTENTIAL. Puric J., Cuk M., Lakicevic I. S., "Proc. 17th Int. Conf. Phenom. Ionized Gases, " 1030-1032 (Budapest, 1985).

4373. OPTICAL DOUBLE RESONANCE AND OPTICAL PUMPING IN HEIDELBERG. Putlitz G. zu, Ann. Phys. (Paris) 10, 571.

4374. VARIATION OF THE ION DYNAMICS PARAMETER IN STARK-BROADENED HELIUM LINES. Richter H.; Piel A., J. Quant. Spectrosc. Radiat. Transfer 33, 615.

4375. STATISTICAL MECHANICS OF DENSE PLASMAS AND IMPLICATIONS FOR THE PLASMA POLARIZATION SHIFT. Rogers F. J., "Spectral Line Shapes," Vol. 3, 121-138 (Ed. F. Rostas, Walter de Gruyter \& Co., New York, 1985).

4376. PARAMETERS OF STARK BROADENING OF NEUTRAL AND SINGLY IONIZED LEAD. Salakhov M. Kh., Sarandaev E. V., Fishman I. S., Opt. Spectrosc. (USSR) 59,118 .

4377. BROADENING AND SHIFT OF NEON I LINES. Schade W., Nick K.-P., Helbig V., "Spectral Line Shapes," Vol. 3, 59-60 (Ed. F. Rostas, Walter de Gruyter \& Co., New York, 1985). 
4378. JOINT EFFECT OF N-ATOM COHERENCES, SATURATION BROADENING, AND COLLISIONS ON ABSORPTION PROFILES OF TWO-LEVEL ATOMS. Schuller F., Nienhuis G., Can. J. Phys. 63, 551 .

4379. EFFECTS OF EMITTER MOTION ON THE PLASMA BROADENING OF HYDROGEN RESONANCE LINES. Seidel J., "Spectral Line Shapes," Vol. 3, 69-70 (Ed. F. Rostas, Walter de Gruyter \& Co., New York, 1985).

4380. PRESSURE BROADENING AND PRESSURE SHIFT OF THE INTERCOMBINATION LINE OF CADMIUM ( $\lambda=3261 \AA$ ) PERTURBED BY ARGON. Sienkiewicz J., Czuchaj E., "Spectral Line Shapes," Vol. 3, 669-670 (Ed. F. Rostas, Walter de Gruyter \& Co. , New York, 1985).

4381. SPECTRAL ABSORPTION MEASUREMENT OF A DENSE NON-IDEAL CESIUM PLASMA. Skowronek M., Rous J., Larour J., "Proc. 17th Int. Conf. Phenom. Ionized Gases," 363-365 (Budapest, 1985).

4382. ELECTRON DENSITY IN TWO H II REGIONS, DR 21 AND W3, FROM STARK-BROADENED RADIO RECOMBINATION LINES. Smirnov G. T., Sov. Astron. Lett. $11,7$.

4383. COLLISIONAL BROADENING OF THE SODIUM D LINES BY ATOMIC HYDROGEN. Smith G., Monteiro T. S., Dickinson A. S., Lewis E. L., Mon. Not. R. Astron. Soc. 217,679 .

4384. ZERO-FIELD LEVEL CROSSING OF THE $633 \mathrm{~nm}$ Ne LINE IN RESONANCE ABSORPTION. Stahlberg B., Lindberg M., Jungner P., J. Phys. B 18, 627.

4385. STAM ET AL. RESPOND: Stamm R., Botzanowski Y., Kaftandjian V. P., Talin B., Smith E. W., Phys. Rev. Lett. 54, 2168.

4386. EFFECT OF ION DYNAMICS ON STARK PROFILES IN HOT AND DENSE PLASMAS: Stamm R., Botzanowski Y., Kaftandjian V. P., Talin B., "Spectral Line Shapes," Vol. 3, 237-238 (Ed. F. Rostas, Walter de Gruyter \& Co., New York, 1985).

4387. IMPACT STARK BROADENING OF THE LYMAN LINES OF HYDROGENIC IONS UNDER DENSE-PLASMA CONDITIONS: FINE-STRUCTURE EFFECTS. Stéhle C., J. Phys. B 18, L43.

4388. STARK BROADENING OF THE HYDROGEN H LINE AT LOW DENSITIES: FINE STRUCTURE AND SPONTANEOUS. EMISSION EFFECTS. Stehlé C., Feautrier N., J. Phys. B 18, 1297. 
4389. STARK BROADENING OF HYDROGEN BALMER $\alpha$ LINE AT LOW DENSITIES. Stehlé C., Feautrier N., "Spectral Line Shapes," Vol. 3, 73-74 (Ed. F. Rostas, Walter de Gruyter \& Co., New York, 1985).

4390. AVERAGE-ATOM MODELS OF LINE BROADENING IN HOT DENSE PLASMAS. Stein J., Shalitin D., Ron A., Phys. Rev. A 31, 446.

4391. DETERMINATION OF. TEMPERATURE PROFILES FROM OPTICALLY THICK LINES.

Stormberg H.-P., Schäfer R., J. Quant. Spectrosc. Radiat. Transfer 33, 27.

4392. INTERPRETATION OF RARE-GAS-INDUCED BROADENING OF RYDBERG SERIES LINES. Ueda K., J. Quant. Spectrosc. Radiat. Transfer 33, 77.

4393. MEASUREMENTS OF ELECTRON DENSITY IN A SF ARC PLASMA. Vacquie S., Gleizes A., Kafrouni H., J. Phys. D 18, 2193.

4394. STARK-WIDTH MEASUREMENTS OF ARGON-ION LINES WITH A FABRY-PEROT INTERFEROMETER. Vaessen P. H. M., van Engelen J. M. L., Bleize J. J., J. Quant. Spectrosc. Radiat. Transfer 33, 51.

4395. INFLUENCE OF THERMAL IONS ON THE $\mathrm{nd}_{3 / 2}-\mathrm{nf}_{5 / 2}$ and $\mathrm{nd}_{3 / 2}-\mathrm{ng}_{7 / 2}$ MICROWAVE TRANSITION OF SODIUM. van Linden van den Heuvell H. B., Tran N. H., Kachru R., Gallagher T. F., J. Appl. Phys. 57, 666.

4396. NON ADIABATIC EFFECTS IN PHOTON ASSISTED SCATTERING PHENOMENA. Van Regemorter H., Feautrier N., "Spectral Line Shapes," Vol. 3, 533-534 (Ed. F. Rostas, Walter de Gruyter \& Co., New York, 1985).

4397. NON-ADIABATIC EFFECTS IN COLLISION-INDUCED RADIATIVE TRANSITIONS. Van Regemorter H., Feautrier N., J. Phys. B 18, 2673.

4398. COLLISIONAL PERTURBATIONS OF $\mathrm{f}-\mathrm{d}$ TRANSITIONS IN SAMARIUM AND THULIUM ATOMS. Vedenin V. D., Kulyasov V. N., Opt. Spectrosc. (USSR) 59, 603.

4399. COLLISION BROADENING AND SOLAR LIMB EFFECT: Na I $3 \mathrm{p}^{2} \mathrm{P}^{\circ}-\mathrm{ns}{ }^{2} \mathrm{~S}$ LINES. Vince I., Dimitrijevic M. S., Krsljanin V., "Spectral Line Shapes," Vol. 3, 649-650 (Ed. F. Rostas, Walter de Gruyter \& Co., New York, 1985).

4400. INFLUENCE OF DIFFERENT LINE BROADENING MECHANISMS ON THE LIMB-EFFECT WITHIN Na I $\left(4 s^{2} \mathrm{~S}-n{ }^{2} \mathrm{P}^{\circ}\right)$ SERIES. Vince I., Dimitrijevic M. S., Publ. Obs. Astron., Belgrade No. 33, 15. 
4401. PRESSURE BROADENING AND SOLAR LIMB EFFECT. Vince I., Dimitrijevic M. S., Krsljanin V., "Progress in Stellar Spectral Line Formation Theory," 373-380 (Eds. J. E. Beckman and L. Crivellari, D. Reidel, Boston, 1985).

4402. FAR WINGS OF THE $6 \mathrm{~s} \Sigma-5 \mathrm{~d} \Sigma$ AND $6 \mathrm{~s} \Sigma-7 \mathrm{~s} \Sigma$ TRANSITIONS IN Cs-He: INFLUENCE OF NON-ADIABATIC EFFECTS. Visticot J. P., Pascale J., Sayer B., J. Phys. B 18,2861 .

4403. INVESTIGATION OF THE EFFECT OF PERTURBATIONS IN AN ACTIVE MEDIUM ON BROADENING OF THE EMISSION LINES OF A STABILIZED He-Ne LASER WITH INTERNAL MIRRORS. Vlasov A. N., Krylov P. S., Privalov V. E., Opt. Spectrosc. (USSR) 58, 436.

4404. SOME ASPECTS OF COOPERATIVE REDISTRIBUTION. Voslamber D., "Spectral Line Shapes," Vol. 3, 469-500 (Ed. F. Rostas, Walter de Gruyter \& Co., New York, 1985).

4405. EXPERIMENTAL STUDY OF WEAK FORBIDDEN COMPONENTS OF THE TWO He I SPECTRAL LINES. Vujicic B. T., Cirkovic Lj. M., "Spectral Line Shapes," Vo1. 3, 35-36 (Ed. F. Rostas, Walter de Gruyter \& Co., New York, 1985).

4406. INSTRUMENT FUNCTION OF THE FABRY-PEROT SPECTROMETER. Wilksch P. A., App1. Opt. 24, 1502 .

4407. ANALYSIS OF SATELLITE AND UNDULATION STRUCTURE IN THE 'SPECTRUM OF Na+Hg CONTINUUM EMISSION: Woerdman J. P., Schlejen J., Korving J., van Hemert M. C., de Groot J. J., van Hal R. P. M., J. Phys. B 18, 4205.

4408. THEORY OF THE SHAPE OF THE VOIGT LINE AND THE DISPERSION CURVE. Zakaraya M. G., Opt. Spectrosc. (USSR) 59, 282.

4409. SERIES MERGING OF HYDROGEN BALMER LINES DURING A STELLAR FLARE. Zarro D. M., Zirin H., Astron. Astrophys. 148, 240.

4410. SPECTRA OF AN ATOM BROADENED BY ITS OWN PRESSURE IN AN ELECTROMAGNETIC FIELD. Zhidkov A. G., Sov. Phys.--JETP 61, 218.

4411. BROADENING OF THE 422.7 nm LINE OF CaI BY ITS OWN AND INERT GAS PRESSURE. Zhuvikin G. V., Penkin N. P., Shabanova L. N., Opt. Spectrosc. (USSR) 58, 750 . 
4412. EXPERIMENTAL INVESTIGATION OF RADIALLY RESOLVED PLASMA PARAMETERS IN A LOW-PRESSURE HELIUM ARC. Adler H., Piel A., J. Phys. D 19, 1477.

4413. MASTER-EQUATION APPROACH TO COLLISIONALLY INDUCED ABSORPTION AND EMISSION. Alber G., Cooper J., Phys.Rev. A 33, 3084.

4414. DETECTION OF LOW-FREQUENCY INSTABILITY THROUGH THE SATELLITES OF A HYDROGEN LIKE ATOM. Amini B., Phys. Fluids 29, 3775.

4415. ELECTRIC MICROFIELD DISTRIBUTION AND RADIAL DISTRIBUTION FUNCTIONS COMPUTED BY THE MONTE-CARLO METHOD. Angelie A:, Gilles D., Ann. Phys. (Paris) 11, Colloq. 3, 157.

4416. NEON LINESHIFT MEASUREMENTS IN DENSE, LASER-COMPRESSED PLASMAS: Baldwin .K. G. H., Liu J. R., Kilkenny J. D., Burgess D. D., J. Phys. B 19, L179.

4417. APPLICATION OF THE MAGNUS FORMALISM TO THE BROADENING OF THE PARTIALLY OVERLAPPING Li I ( $4 \mathrm{f} 4 \mathrm{~d} 4 \mathrm{p}-2 \mathrm{p}$ ) LINE PROFILE, EMITTED BY AN ELECTROLYTIC PLASMA (ANODE EFFECT), INCLUDING ION DYNAMICS. Bardet J. P., Valognes J. C., J. Phys. (Paris) 47, 1203.(Fr.)

4418. MEASUREMENT OF THE PARAMETERS OF A TURBULENT PLASMA IN A THETA-PINCH FROM THE STARK BROADENING OF THE SPECTRAL LINES OF THE HYDROGEN-LIKE ION HeII. Bardinov A. A., Berezin A. B., Burtsev V. A., Lyublin B. V., Ratkevich V. K., Smirnov V. G., Solnyshkov D. A., Yasevich V. Yu., Sov. Phys.--Tech. Phys. 31, 583.

4419. EFFECT OF QUASI-BOUND STATES ON COLLISIONAL REDISTRIBUTION. Belsley M., Alford W. J., Burnett K., Cooper J., J. Quant. Spectrosc. Radiat. Transfer 35, 53 .

4420. OBSERVATION OF RADIATIVE TRANSFER OF POLARIZED LIGHT. Belsley M., Streater A., Burnett K., Ewart P., Cooper J., J. Quant. Spectrosc. Radiat. Transfer 36, 163.

4421. ION TEMPERATURE PROFILE MEASUREMENTS USING THE FAR LINE WINGS OF H $\boldsymbol{\alpha}$. Bengtson R. D., Boédo J., Rowan W. L., Rev. Sci. Iństrum. 57, 2026. 
4422. EFFECTIVE INTERIONIC POTENTIALS FOR THE CALCULATION OF LOW-FREQUENCY ELECTRIC-MICROFIELD DISTRIBUTIONS IN DENSE PLASMAS. Bernu B., Hansen J. P., Mazighi R., Europhys. Lett. 1, 267.

4423. EFFECT OF TEMPERATURE ON THE COLLISION BROADENING AND SHIFT OF THE $2 \mathrm{p}^{5} 3 \mathrm{p}$ - 2p 5 d SPECTRAL LinEs OF NEON PERTURBED BY Ne AND He. Bobkowski R., Bielski A., Szudy J., Wolnikowski J., Acta Phys. Pol. A 69, 347.

4424. FARADAY SPECTROSCOPY STUDY OF COLLISIONAL BROADENING OF HYPERFINE STRUCTURE COMPONENTS OF THE $648 \mathrm{~nm}$ BISMUTH LINE. Bogdanov Yu. V., Kanorskii S. I., Sobel'man I. I., Sorokin V. N., Struk I. I., Yukov E. A., Opt. Spectrosc. (USSR) 61, 281.

4425. THE WIDTHS AND SHAPES OF ABOUT 350 PROMINENT LINES OF 65 ELEMENTS EMITTED BY AN INDUCTIVELY COUPLED PLASMA. Boumans P. W. J. M., Vrakking J. J. A. M., Spectrochim. Acta, Part B 41, 1235.

4426. ABSORPTION PROFILE OF THE $2288 \AA \mathrm{Cd}$ RESONANCE LINE BROADENED BY PRESSURE EFFECTS OF Cd AND $\mathrm{Kr}$ : Cd-Cd AND Cd-Kr INTERACTION POTENTIAL. Bousquet C., J. Phys. B 19, 3859.

4427. PRESSURE BROADENING OF MOLECULAR LINES IN A STARK FIELD. Buffa G., Di Lieto A., Minguzzi P., Tarrini 0., Tonelli M., Phys. Rev. A 34, 1065.

4428. EFFECTS OF DOPPLER BROADENING ON TWO-PHOTON MULTIWAVE MIXING. Capron B. A., Sargent III M., Phys. Rev. A 34, 3034.

4429. H PROFILES AT HIGH ELECTRON DENSITIES FROM OPTICAL CHARGES. Carlhoff C., Krametz E., Schäfer J. H., Uhlenbusch J., J. Phys. B 19, 2629.

4430. INTERPRETATION OF POTENTIAL CURVES OF $\mathrm{ArH}^{+}$FOR SHORT RANGE: THE BLUE WING OF THE LYMAN- $\alpha$. Chambaud G., Levy B., Ann. Phys. (Paris) 11, Colloq. 3, 107. (Fr.)

4431. SELF ABSORPTION AND ESCAPE FACTORS OF Ly- $\beta$ and Ly- $\gamma$ LINES EMITTED BY LOW Z H-LIKE AND He-LIKE IONS. Chenais-Popovics C., Alaterre P., Audebert P., Geindre J. P., Gauthier J. C., J. Quant. Spectrosc. Radiat. Transfer 36, 355 .

4432. DOPPLER-FREE-TWO-PHOTON POLARIZATION-SPECTROSCOPIC MEASUREMENT OF THE STARK-BROADENED PROFILE OF THE HYDROGEN L $\alpha$ LINE IN A DENSE PLASMA. Danzmann K., Grützmacher K., Wende B., Phys. Rev. Lett. 57, 2151. 
4433. ELECTRIC MICROFIELD DISTRIBUTIONS IN PLASMAS OF ARBITRARY DEGENERACY AND DENSITY. Dharma-wardana M. W. C., Perrot F., Phys. Rev. A 33, 3303.

4434. ON THE STARK BROADENING WITHIN A F I TRANSITION ARRAY. Dimitrijevic M. S., Astron. Astrophys., Suppl. Ser. 64, 591.

4435. SIMPLE FORMULAE FOR ESTIMATING STARK BROADENING PARAMETERS OF NEUTRAL ATOM LINEs. Dimitrijevic M. S., Konjevic N., Ann. Phys. (Paris) 11, Colloq. 3, 179 .

4436. SIMPLE FORMULAE FOR ESTIMATING STARK WIDTHS AND SHIFTS OF NEUTRAL ATOM LINES. Dimitrijevic M. S., Konjevic N., Astron. Astrophys. 163, 297.

4437. ELECTRON-IMPACT SHIFTS OF ION LINES: MODIFIED SEMIEMPIRICAL APPROACH. Dimitrijevic M. S., Krsl janin V., Astron. Astrophys. 165, 269.

4438. STARK BROADENING OF NEUTRAL POTASSIUM LINES. Dimitrijevic M. S., Sahal-Bréchot S., Ann. Phys. (Paris) 11, Colloq. 3, 181 (1986).(Fr.)

4439. THE INEQUALITY OF THE STARK WIDTHS WITHIN A MULTIPLET OR SUPERMULTIPLET OF ARGON II. Dimitrijjevic M. S., Truong-Bach, Ann. Phys. (Paris) 11, Colloq. 3, 183 (1986).

4440. ON THE STARK BROADENING OF SINGLY IONIZED ARGON LINES. Dimitrijevic M. S., Truong-Bach, Z. Naturforsch., Teil A 41, 772.

4441. THE Rb(6S, 4D)-Ar, He INTERACTION: INTERACTION POTENTIALS AND OSCILLATOR STRENGTH OF THE 5S, 6S'AND 4D TRANSITIONS. Dubourg I., Ferray M., Visticot J. P., Sayer B., Ann. Phys. (Paris) 11, Colloq.3, 203.(Fr.)

4442. EXPERIMENTAL INVESTIGATION OF THE Rb(6S or 4D)-RARE GAS INTERACTION: DETERMINATION OF INTERACTION POTENTIALS AND OSCILLATOR STRENGTHS. Dubourg I., Ferray M., Visticot J. P., Sayer B., J. Phys. B 19, 1165.

4443. EVIDENCE OF SATELLITE LINES OF THE FORBIDDEN 3P-nF TRANSITIONS OF SODIUM. Fabry M., N'Dollo M., J. Phys. (Paris) 47, 809.(Fr.)

4444. STOCHASTIC THEORY OF LINE SHAPE AND RELAXATION. Faid K., Fox R. F., Phys. Rev. A 34, 4286. 
4445. STARK SHIFTS DUE TO BLACK-BODY RADIATION. Ford G. W., Lewis J. T., O'Connel1 R. F., J. Phys. B 19, L41.

4446. SPONTANEOUS EMISSION AND THE NATURAL BROADENING SHAPE OF SPECTRAL LINES IN THE T-MATRIX THEORY. Gainutdinov R. Kh., Opt. Spectrosc: (USSR) 60, 549 .

4447. HYDROGEN STARK BROADENING: STUDY OF THE BINARY COLLISION AND COMPLETE BINARY COLLISION HYPOTHESES IN A COMPUTER SIMULATED PLASMA. Gigosos M. A., Cardenoso V., Ann. Phys. (Paris) 11, Colloq. 3, 185.

4448. STARK-BROADENING SIMULATION IN HYDROGEN: STUDY OF THE BINARY AND COMPLETE BINARY COLLISION HYPOTHESES. Gigosos M. A., Cardenoso V., Torres F., J. Phys. B 19, 3027 .

4449. NEW STARK BROADENING CALCULATIONS: I. HYDROGEN. Gigosos M. A., Torres F., Ann. Phys. (Paris) 11, Colloq. 3, 187.

4450. MODEL OF STARK BROADENING IN HYDROGEN WHICH INCLUDES THE LACK OF REGULARITY IN THE COLLISIONS. Gigosos M. A., Torres Y. F., An. Fis., Ser. A $82,24$. (Span.)

4451. CALCULATIONS OF THE STARK BROADENING IN HELIUM II, INCLUDING FLUCTUATIONS IN THE NUMBER OF COLLISIONS. Gigosos M. A., Torres Y. F., An. Fis., Ser. A $82,49$. (Span.)

4452. STARK BROADENING OF SOME C I AND N I VACUUM ULTRAVIOLET LINES. Goly A., Weniger S., J. Quant. Spectrosc. Radiat. Transfer 36, 147.

4453. SATURATED TWO-PHOTON ABSORPTION BY CALCIUM ATOMS IN A PERTURBER BATH. Granier R., Charton G., Granier J., J. Quant. Spectrosc. Radiat. Transfer 36,113 .

4454. JOINT PROBABILITY DISTRIBUTION FOR STARK-BROADENING CALCULATIONS. Greene R. L., Phys. Rev. A 34, 4091.

4455. LINE PROFILES OF SOFT-X-RAY LASER GAIN COEFFICIENTS. Griem H. R., Phys. Rev. A 33, 3580.

4456. QUASISTATIC HYDROGEN-LINE BROADENING IN PLASMA. Gulyaev S. A., Sholin G. V., Sov. Astron.--AJ 30, 31. 
4457. SHIFT MEASUREMENTS OF $\mathrm{H}_{\alpha}$ and $\mathrm{H}_{\beta}$ LINES IN ARC PLASMAS. Halenka J., Musielok J., J. Quant. Spectrosc. Radiat. Transfer 36, 233.

4458. MEASUREMENT OF THE BROADENING AND ASYMMETRY OF THE CALCIUM RESONANCE LINE $(422.7 \mathrm{~nm}$ ). Harris M., Lewis E. L., McHugh D. R., Shannon I., J. Phys. B 19,3207 .

4459. COMMENTS ON THE PAPER "STUDY OF THE BALMER BETA CORE IN A PULSED ARC PLASMA" BY TORRES, GIGOSOS AND MAR. Helbig V., Nick K.-P., J. Quant. Spectrosc. Radiat. Transfer 36, 85.

4460. CORRELATION FUNCTIONS AND MICROFIELD WITH TWO IONIC COMPONENTS. Held B., Pignolet P., Ann. Phys. (Paris) 11, Colloq. 3, 155.(Fr.)

4461. SEMI-EMPIRICAL CORRELATION FUNCTION FOR ONE AND TWO-IONIC COMPONENT Plasmas. Held B., Pignolet P., J. Phys. (Paris) 47, 437 (1986).

4462. BARANGER-MOZER PLASMA SATELLITES: LINESHAPE MODULATION VERSUS ENERGETIC DIPOLE INTERACTION. Hildebrandt J., J. Phys. B 19, L127.

4463. DETERMINATION OF ELECTRON DENSITY IN DISCHARGE-PUMPED EXCIMER LASER USING STARK BROADENING OF $\mathrm{H}_{\beta}$ LINE. Hiramatsu M., Furuhashi H., Goto T., J. Appl. Phys. 60, 1946 (1986).

4464. GREEN'S FUNCTION APPROACH TO THE ELECTRON SHIFT AND BROADENING OF SPECTRAL LINES IN NON-IDEAL PLASMAS. Hitzschke L., Röpke G., Seifert T., Zimmermann R., J. Phys. B 19, 2443.

4465. REDISTRIBUTION OF RADIATION IN THE PRESENCE OF VELOCITY-CHANGING COLLISIONS. Hubeny I., Cooper J., Astrophys. J. 305, 852.

4466. RATIONAL APPROXIMATIONS FOR THE HOLTSMARK DISTRIBUTION, ITS CUMULATIVE AND DERIVATIVE. Hummer D. G., J. Quant. Spectrosc. Radiat. Transfer 36, 1.

4467. PECULIARITIES OF THE DETERMINATION OF THE TEMPERATURE OF A FREELY BURNING ARC DISCHARGE FROM SELF-REVERSED RESONANGE SPECTRAL LINES OF ATOMS. Il'in G. G., Nurmatov E. M., Fishman I. S., High. Temp. (USSR) 24, 117.

4468. ION BROADENING OF Ar I LINES IN A PLASMA. Jones D. W., Wiese W. L., Woltz L. A., Phys. Rev. A 34, 450. 
4469. NONADIABATIC THEORY OF ATOMIC LINE BROADENING: REDISTRIBUTION CALCUlations FOR $\operatorname{Sr}\left({ }^{1} \mathrm{P}-{ }^{1} \mathrm{~S}\right)+$ Ar. Julienne P. S., Mies F. H., Phys. Rev. A 34, 3792 .

4470. SPECTRAL SHIFT BY THE POLARIZATION EFFECT IN PLASMAS. Koenig M., Terray L., Benred jem D., Coulaud G., Nguyen Hoe, Ann. Phys. (Paris) 11, Colloq. 3, 153.(Fr.)

4471. STARK BROADENING OF SINGLY IONIZED NEON LINES. Konjevic N., Pittman T. L., J. Quant. Spectrosc. Radiat. Transfer 35, 473.

4472. STARK BROADENING AND SHIFT OF NEUTRAL COPPER SPECTRAL LINES. Konjevic R., Konjevic N., Fizika (Zagreb) 18, 327.

4473. DETERMINATION OF THE BROADENING OF THE $2 \mathrm{p}_{4}$ NEON LEVEL BY DEPOLARIZING COLLISIONS WITH INERT GASES. Kotlikov E. N., Perchuk O. V., Opt. Spectrosc. (USSR) 61, 560 .

4474. OPTIMIZATION OF THE CALCULATION OF SPECTRAL LINE HALF-WIDTHS. Kuznetsov S. V., Cherkasov M. R., Opt. Spectrosc. (USSR) 60, 140.

4475. EXACT SOLUTION OF THE MEAN SPHERICAL MODEL FOR THE ELECTRIC MICROFIELD DISTRIBUTION IN A PLASMA. Lado F., Phys. Rev. A 34, 4131.

4476. AC STARK SPLITTING IN MULTIPHOTON EXCITATION OF ATOMIC HYDROGEN IN FLAMES: ABNORMAL PEAK ASYMMETRY DUE TO PRESSURE BROADENING. LaU A. M. F., Phys. Rev. A 33, 3602 .

4477. BROADENING COEFFICIENTS AND SHIFTS OF THE SODIUM D LINES, PERTURBED BY HELIUM AT HIGH TEMPERATURE. Lemaire J. L., Chotin J. L., Rostas F., Ann. Phys. (Paris) 11, Colloq. 3, 227.(Fr.)

4478. BROADENING AND SHIFT PARAMETERS OF THE SODIUM D LINES PERTURBED BY HELIUM. Lemaire J. L., Chotin J. L., Rostas F., J. Phys. B 19, 1913.

4479. ROLE OF POLARIZATION SHIFT ON THE PROFILE OF SPECTRAL LINES EMITTED BY A LASER-PRODUCED PLASMA. Lemaire P., Jaeglé P., Carillon A., Jamelot G., Ann. Phys. (Paris) 11, Colloq. 3, 61.(Fr.)

4480. NOBLE-GAS BROADENING OF THE FINE-STRUCTURE TRANSITION IN CAESIUM $7 \mathrm{P}_{1 / 2}$ $7 \mathrm{P}_{3 / 2}$ ) USING TRI-LEVEL ECHOES. Manners J., Durrant A. V., Opt. Commun. 58,389 . 
4481. EXPERIMENTAL STARK PARAMETERS FOR SOME SPECTRAL LINES IN SF ${ }_{6}$ PLASMA. Mar S., Czernichowski A., Chapelle J., J. Phys. D 19, 43.

4482. AN EVALUATION OF METHODS FOR ESTIMATING THE ELECTRON STARK WIDTHS OF ATOMIC SPECTRAL LINES. Marasinghe P. A. B., Lovett R. J., Spectrochim. Acta, Part B 41, 349 .

4483. A CONVERGENT ANALYSIS OF RADIATIVE MATRIX ELEMENTS IN ATOMIC LINESHAPE THEORY. Mies F. H., Julienne P. S., Band Y. B., Singer S. J., J. Phys. B $19,3249$.

4484. LINE SHAPES IN HIGH-RESOLUTION OPTOACOUSTIC SPECTROSCOPY. Minguzzi P., Profeti S., Tonelli M., Di Lieto A., J. Opt. Soc. Am. B 3, 1075.

4485. BROADENING OF THE $\mathrm{Ca}^{+}$AND $\mathrm{Mg}^{+}$RESONANCE LINES BY COLLISIONS WITH HELIUM. Monteiro T. S., Cooper I. L., Dickinson A. S., Lewis E. L., J. Phys. B 19,4087 .

4486. PRESSURE BROADENING OF ARGON SPECTRAL LINES; INTERACTION POTENTIAL OF THE $\mathrm{Ar}_{2}$ DIMER AT AVERAGE RANGE. Moussounda P. S., Ranson P., Spiegelmann F., Ann. Phys. (Paris), 11, Colloq. 3, 77.(Fr.)

4487. STIMULATED PROCESSES IN A MIXTURE OF RUBIDIUM VAPOR AND BUFFER GAS UNDER TWO-PHOTON EXCITATION. Movsesyan M. E., Ovakimyan T. O., Shmavonyan S. V., Opt. Spectrosc. (USSR) 61; 285.

4488. A NEW TECHNIQUE FOR THE REAL-TIME RECOVERY OF FABRY-PEROT LINE PROFILES. Mulligan F. J., J. Phys. E 19, 545.

4489. MEASUREMENTS OF STARK WIDTHS OF Ge I LINES. Musiol K., Polrzywka B., Labuz S., Ann. Phys.(Paris) 11, Colloq. 3, 143.

4490. IMPACT BROADENING AND SHIFT OF THALLIUM TWO-PHOTON $6{ }^{2} \mathrm{P}_{1 / 2}-5{ }^{2} \mathrm{~F}$ TRANSITION BY He AND $\mathrm{N}_{2}$. Naqvi A. S., Naveedullah K., Rethmatulla M. I., Opt. Commun. 58, 311 .

4491. ATOMIC STRUCTURE AND POLARIZATION LINE SHIFT IN DENSE AND HOT PLASMAS. Nguyen Hoe, Koenig M., Benred jem D., Caby M., Coulaud G., Phys. Rev. A 33,1279 . 
4492. EXPERIMENTAL STARK BROADENING PARAMETERS FOR Ar II AND Xe II LINES. Nick K. -P., Helbig V., Phys. Scr. 33, 55.

4493. COMMENTS ON THE BROADENING OF THE SODIUM D LINES BY COLLISIONS WITH ATOMIC HYDRogen. O'Mara B. J., J. Phys. B 19, L349.

4494. NEW METHOD OF DETERMINING SPECTRAL LINE PROFILE USING THE FABRY-PEROT INTERFEROMETER. Okada K., Yoshihara K., Kitade A., Jpn. J. Appl. Phys., Pt. 2 25, L918 (1986).

4495. DRASTIC INFLUENCE OF PLASMA QUASI-STATIC ELECTRIC FIELDS ON SATELLITES OF HELIUM FORBIDDEN LINES. Oks E. A., Gavrilenko V. P., Opt. Commun. 56, 415.

4496. STARK BROADENING OF $\mathrm{H}_{\alpha}$ AND $\mathrm{H}_{\beta}$ LINES OF $\mathrm{C}^{5+}$. Oza D. H., Greene R. L., Kelleher D. E., Phys. Rev. A 34, 4519.

4497. DIFFUSION COEFFICIENTS OF NORMAL AND EXCITED THALLIUM ATOMS IN INERT GASES. Penkin N. P., Redko T. P., Kryukov N. A., Opt. Spectrosc. (USSR) $60,17$.

4498. LASER ENHANCEMENT OF THE COLLISIONAL BROADENING OF THE 4713 AND $3188 \AA$ LINES IN A HELIUM Plasma. Pignolet P., Dubreuil B., J. Phys. B 19, 883.

4499. PLASMA SHIFTS OF THE He II $\mathrm{H}_{\alpha}$ AND $\mathrm{P}_{\alpha}$ LINES. Pittman T. L., Fleurier C., Phys. Rev. A 33, 1291.

4500. STARK BROADENING ALONG HOMOLOGOUS SEQUENCES OF SINGLY IONIZED NOBLE GASES. Pittman T. L., Konjevic N., J. Quant. Spectrosc. Radiat. Transfer 35,247 .

4501. ELECTRICAL AND OPTICAL PROPERTIES OF HIGH-PRESSURE ARGON PLASMA. Poise1 H., Landers F. J., Höss P., Bauder U. H., IEEE Trans. Plasma Sci. PS-14, 306.

4502. RADIATIVE TRANSPORT AT THE 184.9-nm Hg RESONANCE LINE. I. EXPERIMENT AND THEORY. Post H. A., Phys. Rev. A 33, 2003.

4503. RADIATIVE TRANSPORT AT THE 184.9-nm Hg RESONANCE LINE. II. EXTENSIVE EXPERIMENTS . Post H. A., van de Weijer P., Cremers R. M. M., Phys. Rev. A 33, 2017. 
4504. STUDY OF THE BALMER SPECTRUM OF HYDROGEN FROM A HIGH-PRESSURE ARC DISCHARGE. Radtke R., Günther K., Contrib. Plasma Phys. 26, 143.

4505. STUDY OF THE BALMER SPECTRUM OF HYDROGEN FROM A HIGH-PRESSURE ARC DISCHARGE. II. COMPARISON OF EXPERIMENT AND THEORY . Radtke R., Günther K., Spanke R., Contrib. Plasma Phys. 26, 151.

4506. SEMI-EMPIRICAL EVALUATION OF Sr-Ar DIFFERENCE POTENTIALS. Rang L. Q., Voslamber D., J. Phys. (Paris) 47, 1149.

4507. PLASMA-INDUCED BROADENING OF ATOMIC LEVELS OF SHIFTED TERMS LYING BELOW THE IONIZATION BOUNDARY. Ryabtsev A. N., JETP Lett. 44, 158.

4508. SHIFT AND PROFILE OF THE $\mathrm{H}_{\alpha}$ HYDROGEN LINE AT ELECTRON DENSITIES OF THE ORDER OF $10^{18} \mathrm{~cm}^{-3}$. Salakhov M. Kh., Sarandaev E. V., Latipov R. Z., Fishman I. S., Opt: Spectrosc. (USSR) 60, 264.

4509. DEPOLARIZATION MECHANISMS IN ALKALI-NOBLE GAS HALF COLLISIONS. Schuller F., Nienhuis G., Behmenburg W., Z. Phys. D 2, 193.

4510. COMPUTER SimULATION OF THE PLASMA BROADENING OF HYDROGEN BALMER- $\alpha$. Seide1 J., Ann. Phys. (Paris) 11, Colloq. 3, 149.

4511. THEORY OF TWO-PHOTON POLARIZATION SPECTROSCOPY OF PLASMA-BROADENED HYDROGEN L $\alpha$ LINE. Seidel J., Phys. Rev. Lett. 57, 2154.

4512. ASYMMETRY IN THE PROFILES OF THE 466.2, 462.7, AND 459.4-nm LINES OF Eu I DURING RESONANCE BROADENING. Shabanova L. N., Levoshkin A. V., Opt. - Spectrosc. (USSR) 61, 142 .

4513. PROFILES OF 466.2, 462.7, AND 459.4-nm EuI LINES IN THE PRESENCE OF NEON. Shabanova L. N., Levoshkin A. V., Opt. Spectrosc. (USSR) 61, 408.

4514. LOW-PRESSURE SPECTRAL LINE PROFILES: AN ANALYSIS IN TERMS OF ASYMMETRIC SPEED-DEPENDENT VOIGT PROFILES. Shannon I., Harris M., McHugh D. R., Lewis E. L., J. Phys. B 19, 1409.

4515. A DEĊONVOLUTION TECHNIQUE WITH SMOOTH, NON-NEGATIVE RESULTS. Smulders P. J. M., Nucl. Instrum. Methods Phys. Res., Sect. B 14, 234. 
4516. LINE PROFILES OF MULTICHARGED IONS IN HOT, DENSE PLASMAS. Stamm R., Kaftandjian V. P., Talin B., Ann. Phys. (Paris) 11, Colloq. 3, 141.(Fr.)

4517. ION-DYNAMIC EFFECTS ON THE LINE SHAPES OF HYDROGENIC EMITTERS IN PLASMAS. Stamm R., Talin B., Pollock E. L., Iglesias C. A., Phys. Rev. A 34,4144 .

4518. STARK BROADENING OF THE HYDROGEN LYMAN- $\alpha$ LINE FROM THE CENTER TO THE NEAR LINE WINGS FOR LOW-DENSITY PLASMAS. Stehlé C., Phys. Rev. A 34, 4153.

4519. MODEL FOR REDISTRIBUTION OF FLUORESCENCE IN PLASMAS. Talin B., Kaftandjian V. P., Stamm R., Ann. Phys. (Paris) 11, Colloq. 3, 139.(Fr)

4520. BORON-RARE GAS INTERACTION POTENTIALS: BROADENING AND QUENCHING OF BORON EMISSION LINES. Taylor P. R., Chem. Phys. 105, 79.

4521. NEW STARK BROADENING CALCULATIONS: II. HELIUM II. Torres F., Gigosos M. A., Ann. Phys. (Paris) 11, Colloq. 3, 191.

4522. STARK BROADENING OF THE He I 4471- $\AA$ LINE AND ITS FORBIDDEN COMPONENT IN DENSE COOL PLASMA. Uzelac N. I., Konjevic N., Phys. Rev. A 33, 1349.

4523. EFFECT OF POPULATION REDISTRIBUTION THROUGH Na-Ar AND Na-Na COLLISIONS ON SATURATION CURVES IN A VAPOR CELL. van den Wijngaart, Kuik P., Dijkerman H. A., Hollander Tj., Krause L., Alkemade C. Th. J., J. Quant. Spectrosc. Radiat. Transfer 35, 1.

4524. THE BINARY MODEL FOR COLLISIONAL REDISTRIBUTION OF LIGHT. Van Regemorter H., Ann. Phys. (Paris) 11, Colloq. 3, 133.

4525. THE BINARY MODEL FOR COLLISIONAL REDISTRIBUTION OF LIGHT. Van Regemorter H., J. Phys. B 19, 2235.

4526. SHAPE OF SPECTRAL LINES EMITTED FROM A GAS IN THE PRESENCE OF A CONDENSED PHASE. Vasilieva I. A., J. Quant. Spectrosc. Radiat. Transfer 35, 171.

4527. "NEUTRAL AND PLASMA" ROUND TABLE ON SPECTRAL LINE BROADENING IN NEUTRAL GASES AND IN PLASMAS. Voslamber D., Ann. Phys. (Paris) 11, Colloq. 3, 103. (Fr.) 
4528. REDISTRIBUTION OF RADIATION BY SLOWLY PERTURBED ATOMS. Voslamber D., J. Phys. B 19, 3233 .

4529. RAYLEIGH COMPONENT OF THE REDISTRIBUTION FUNCTION. Voslamber D., Phys. Rev. A34, 3521.

4530. ELECTRON DENSITY CHARACTERIZATION OF 27.1 AND $50 \mathrm{MHz}$ INDUCTIVELY COUPLED PLASMAS BY MEANS OF ABEL CORRECTED STARK BROADENED $\mathrm{H}_{\beta}$ LINE PROFILES. Walters P. E., Gunter W. H., Zeeman P. B., Spectrochim. Acta, Part B 41, 133.

4531. BROADENING AND SHIFT OF THE $3 \mathrm{p}^{5} 4 \mathrm{p}-3 \mathrm{p}^{5} 4 \mathrm{~d}$ ARGON SPECTRAL LINES IN PURE ARGON, ARGON-NEON AND ARGON-HELIUM MIXTURES. Wawrzynski J., Wolnikowski J., Phys. Scr. 33, 113.

4532. PRESSURE EFFECTS ON THE $542.2\left(3 p^{5} 4 p-3 p^{5} 8 s\right)$ and $545.2\left(3 p^{5} 4 p-3 p^{5} 7 s\right)$ nm SPECTRAL LINES OF ARGON. Wolnikowski J., Bielski A., Szudy J., Acta Phys. Pol. A 69, 361 .

4533. QUASI-STATIC ION BROADENING OF ISOLATED SPECTRAL LINES. WOItZ L. A., J. Quant. Spectrosc. Radiat. Transfer 36, 547.

4534. NOBLE-GAS-INDUCED COLLISIONAL LINE BROADENING OF ATOMIC LITHIUM RYDBERG SUPERPOSITION STATES $2 \mathrm{~S}-\mathrm{nS}$ and $2 \mathrm{~S}-\mathrm{nD}(\mathrm{n}=4$ to 30$)$ MEASURED BY TRILEVEL ECHOES. Xu E. Y., Moshary F., Hartmann S. R., J. Opt. Soc. Am. B 3, 497.

4535. THEORY OF INTERPARTICLE CORRELATIONS IN DENSE, HIGH-TEMPERATURE PLASMAS. VI. PROBABILITY DENSITIES OF THE ELECTRIC MICROFIELDS. Yan X. Z., Ichimaru S., Phys. Rev. A 34, 2167.

4536. THEORY OF INTERPARTICLE CORRELATIONS IN DENSE, HIGH-TEMPERATURE PLASMAS. VII. POLARIZATION SHIFT OF SPECTRAL LINES. Yan X. Z., Ichimaru S., Phys. Rev. A 34, 2173.

4537. EFFECT OF FINE STRUCTURE ON THE LINE SHAPE OF HYDROGENLIKE IONS. Zhidkov A. G., Tkachev A. N., Yakovlenko S. I., Sov. Phys.--JETP 64, 261.

4538. COMPOSITE POPULATION KERNELS IN YTTERBIUM-BUFFER COLLISIONS STUDIED BY MEANS OF LASER-SATURATED ABSORPTION. Zhu X., Phys. Rev. A 33, 251. 
4539. PERTURBATION OF FORBIDDEN TRANSITIONS IN THALLIUM AND THULIUM ATOMS COLLIDING WITH INERT GAS ATOMS. Agladze N. I., Balashov A. A., Vedenin V. D., Kulyasov V. N., Opt. Spectrosc. (USSR) 63, 6.

4540. UNIFIED THEORIES OF THE PRESSURE BROADENING AND SHIFT OF SPECTRAL LINES: I I. VAN DER WAALS INTERACTIONS. Al-Saqabi B. N. I., Peach G., J. Phys. B 20,1175 .

4541. COLLISIONAL PHASE DETERMINATION FOR PSEUDO-MOLECULE FORMATION. Allard $\mathrm{N}$. F., Biraud Y. G., Chevillot A., C. R. Acad. Sci., Ser. II304, 779.(Fr.)

4542. LASER-INDUCED FLUORESCENCE AND DOPPLER-FREE POLARIZATION SPECTRA IN A LOW DENSITY HYDROGEN PLASMA. Arata Y., Miyake S., Matsuoka H., Jpn. J. Appl. Phys. 26, 331 .

4543. EFFECT OF PLASMA OPACITY ON THE DOPPLER-FREE POLARIZATION SPECTRUM IN A HYDROGEN PLASMA. Arata Y., Miyake S., Matsuoka H., Jpn J. Appl. Phys. 26,1285 .

4544. REDISTRIBUTION OF RADIATION IN RESONANCE FLUORESCENCE INDUCED BY DIFFUSING MODES OR BY AN EXTRA LASER. Argawal G. S., Lakshmi P. A., Phys. Rev. A 35, 3152 .

4545. COLLISIONAL REDISTRIBUTION BEYOND THE MEDIUM-COUPLING LIMIT. Arnoldus $\mathrm{H}$. F., George T. F., J. Phys. B 20, 2203.

4546. ELECTRON-PRODUCED SHIFT AND WIDTH OF $2121^{\prime}$ DIELECTRONIC SATELLITE LINES. Banon J. M., Nguyen Hoe, J. Phys. B 20, 2989.

4547. DOPPLER-BROADENED H $\alpha$ LINE SHAPES IN A RF LOW-PRESSURE $\mathrm{H}_{2}$ DISCHARGE. Baravian G., Chouan Y., Ricard A., Sultan G., J. Appl. Phys. 61, 5249.

4548. COLLISIONAL REDISTRIBUTION BY LASER-INDUCED FLUORESCENCE IN THE Ba-Ar SYSTEM. Belsley M., Cooper J., Phys. Rev. A 35, 1013.

4549. TEST OF QUASICLASSICAL THEORIES OF REDISTRIBUTION IN ATOMIC COLLISIONS. Bieniek R. J., Phys. Rev. A 35, 3663. 
4550. EXCITATION, IONIZATION, AND SPECTRAL LINE EMISSION IN THE INDUCTIVELY COUPLED PLASMA. Blades M. W., Caughlin B. L., Walker Z. H., Burton L. L., Prog. Anal. Spectrosc. 10, 57.

4551. TEMPERATURE DEPENDENCE OF THE WIDTH AND SHIFT OF THE SELF BROADENED 582.02 nm NEON LINE. Bobkowski R., Bielski A., Lisicki E., Szudy J., Acta Phys. Pol. A 72, 709 .

4552. RADIATIVE AND TRANSPORT PROPERTIES OF IONS IN STRONGLY COUPLED PLASMAS. Boercker D. B., Iglesias C. A., Dufty J. W., Phys. Rev. A 36, 2254.

4553. STUDY OF THE COLLISIONAL BROADENING OF THE BISMUTH LINE 648 nm HYPERFINE COMPONENTS BY FARADAY ROTATION SPECTROSCOPY. Bogdanov Yu. V., Kanorskii S. I., Acta Phys. Hung. 61, 13 .

4554. STARK BROADENING OF C IV AND $N$ V LINES IN THE VACUUM-UV SPECTRAL RANGE. Böttcher F., Musielok J., Kunze H.-J., Phys. Rev. A 36, 2265.

4555. INDUCTIVELY COUPLED PLASMAS: LINE WIDTHS AND SHAPES, DETECTION LIMITS AND SPECTRAL INTERFERENCES. AN INTEGRATED PICTURE. Boumans P. W. J. M., Vrakking J. J. A. M., J. Anal. At. Spectrom. 2, 513.

4556. PRACTICAL EXPERIENCE WITH THE MEASURING OF THE SPECTRAL LINE PROFILE BY MEANS OF THE FABRY-PEROT INTERFEROMETER. Brablec A., Stastny F., Acta Phys. Slov. 37, 155.

4557. INFLUENCE OF INSTRUMENTAL BROADENING ON LINESHAPES DETECTED BY PMT AND PHOTODIODE ARRAY DETECTORS. Burton L. L., Blades M. W., Spectrochim. Acta, Part B 42, 513.

4558. EFFECT OF THE ION MICROFIELD FLUCTUATIONS ON THE LYMAN- $\alpha$ FINE-STRUCTURE DOUBLET OF HYDROGENIC IONS IN DENSE PLASMAS. Calisti A., Stamm R., Talin B., Europhys. Lett. 4, 1003.

4559. ELECTRON DENSITY RADIAL PROFILES DERIVED FROM STARK BROADENING IN A SODIUM PLASMA PRODUCED BY LASER RESONANCE SATURATION. Cappelli M. A., Measures R. M., Appl. Opt. 26, 1058.

4560. A GENERAL EXPRESSiON FOR THE VOIGT PROFILE. Cope D., Lovett R. J., J. Quant. Spectrosc. Radiat. Transfer 37, 377. 
4561. EFFECT OF COLLISIONS ON FORBIDDEN LINES. Coutts J., Peck S. K., Stoner R., Cooper J., J. App1. Phys. 62, 3514.

4562. FLUORINE LYMAN SERIES EMITTED FROM LASER-PRODUCED PLASMAS - LINE BROADENING AND MERGING EFFECTS. d'Etat B., Grumberg J., Leboucher E., Nguyen Hoe, Poquerusse A., J. Phys. B 20, 1733.

4563. THEORETICAL AND EXPERIMENTAL STUDY OF COMPLETE SPECTRAL SERIES AS A DIAGNOSTIC TOOL FOR DENSE PLASMAS. d'Etat B., Grumberg J., Leboucher E., Nguyen Hoe, Poquerusse A., Laser Part. Beams 5, 155.

4564. STATISTICAL MECHANICS OF PARTIALLY IONIZED STELLAR PLASMAS: THE PLANCKLARKIN PARTITION FUNCTION, POLARIZATION SHIFTS, AND SIMULATIONS OF OPTICAL SPECTRA. Däppen W., Anderson L., Mihalas D., Astrophys. J. 319, 195.

4565. SIMPLE ESTIMATES FOR STARK BROADENING OF ION LINES IN STELLAR PLASMAS. Dimitrijevic M. S., Konjevic N., Astron. Astrophys. 172, 345.

4566. STARK BROADENING TRENDS ALONG HOMOLOgOUS SEQUENCES. Dimitrijevic M. S., Mihajlov A. A., Popovic M. M., Astron. Astrophys., Suppl. Ser. 70, 57.

4567. STARK BROADENING OF NEUTRAL POTASSIUM LINES. Dimitrijevic M. S., Sahal-Bréchot S., J. Quant. Spectrosc. Radiat. Transfer 38, 37.

4568. DISTRIBUTION OF SPECTRAL LINES IN PLASMA WITH RESPECT TO THE FLUCTUATIONS OF THE FILLING NUMBER. Dragalov V. V., Novikov V. G., High Temp. (USSR) 25,762 .

4569. TRANSFORMATION OF THE HYDROGEN LINE SPECTRUM INTO A CONTINUOUS SPECTRUM IN PLASMA MiCROfields. Dyachkov L. G., Kobzev G. A., Pankratov P. M., Opt. Spectrosc. (USSR) 63, 147.

4570. PRESSURE EFFECTS OF NEON AND ARGON ON THE $535 \mathrm{~nm}$ THALLIUM LINE. Dygdala R. S., Bobkowski R., Lisicki E., Szudy J., Z. Naturforsch., Teil A 42, 559.

4571. BROADENING AND SHIFT OF THE $8 \mathrm{p}{ }^{2} \mathrm{P}_{1 / 2,3 / 2}-7 \mathrm{~s}^{2} \mathrm{~S}_{1 / 2}$ THALLIUM SPECTRAL LINES PERTURBED BY NEON AND ARGON. Dygdala R. S., Lisicki E., Szudy J., J. Phys. B 20, 3001 . 
4572. PLASMA SPECTROSCOPY OF $\mathrm{H}$, Li, AND Na IN PLUMES RESULTING FROM LASER-INDUCED DROPLET EXPLOSION. Eickmans J. H., Hsieh W.-F., Chang R. K. , Appl. Opt. 26, 3721 .

4573. DEPOLARIZATION AND FINE STRUCTURE EFFECTS IN HALF COLLISIONS OF SODIUM-NOBLE GAS SYSTEMS. Ermers A., Woschnik T., Behmenburg W., Z. Phys. D 5, 113 .

4574. HALF-COLLISION ANALYSIS OF FAR-WING DIFFUSE STRUCTURE IN Cs-Xe. Exton R. J., Hillard M. E., Lempert W. R., J. Phys. B 20, L463.

4575. RESONANCE BROADENING AND SHIFTING OF SPECTRAL LINES IN XENON AND KRYPTON. Ferrell W. R., Payne M. G., Garrett W. R., Phys. Rev. A 36, 81.

4576. TEMPERATURE DETERMINATION OF AN OPTICALLY THICK PLASMA FROM SELF-REVERSED SPECTRAL LINES. Fishman I. S., Il'in G. G., Salakhov M. Kh., J. Phys. D 20,728 .

4577. PASCHEN-LINE STARK-BROADENING AS AN ELEGTRIC FIELD DIAGNOSTIC IN ERUPTING PROMINENCES. Foukal P., Little R., Gillian L., Sol. Phys. 114, 65.

4578. OPTOGALVANIC MEASUREMENT OF THE CATHODE-FALL REGION OF Kr HOLLOW CATHODE DISCHARGE. Fujimaki S., Adachi Y., Hirose C., Appl. Spectrosc. 41, 567.

4579. NATURAL BROADENING OF ATOMIC SPECTRAL LINES IN THE PRESENCE OF ENERGY-LEVEL SUPERPOSITION. Gainutdinov R. Kh., Salakhov M. Kh., Opt. Spectrosc. (USSR) 63, 274.

4580. STUDY OF THE EFFECTS OF ION DYNAMICS ON STARK PROFILES OF BALMER- $\alpha$ AND $\beta$ LINES USING SIMULATION TECHNIQUES. Gigosos M. A., Cardenoso V., J. Phys. B 20, 6005 .

4581. EFFECTS OF DIELECTRONIC SATELLITE BROADENING ON THE EMISSION SPECTRA FROM HOT PLASMAS. Goldberg A., Rozsnyai B. F., NATO ASI Ser., Ser. B 154, 545 .

4582. ANOMALOUS BLUE SHIFTED EMISSION NEAR THE $\mathrm{D}_{1}$ TRANSITION FROM LASER-EXCITED SODIUM VAPOR. Golub I., Shuker R., Erez G., J. Phys. 20, L63.

4583. WIDTHS AND SHIFTS OF SOME PLASMA-BROADENED OXYGEN AND GARBON MULTIPLETS. Goly A., Weniger S., J. Quant. Spectrosc. Radiat. Transfer 38, 225. 
4584. BROADENING AND SHIFT OF Fe I LINES PERTURBED BY ATOMIC HYDROGEN. Gomez $M$. T., Marmolino G., Roberti G., Severino G., Sol. Phys. 112, 227.

4585. LASER LINE BROADENING DUE TO CLASSICAL AND QUANTUM NOISE AND THE FREE-ELECTRON-LASER LINEWIDTH. Gover A., Amir A., Elias L. R., Phys. Rev. A $35,164$.

4586. EFFECTS OF DEBYE SHIELDING IN THE ELECTRON BROADENING CALCULATIONS. Grabowski B., Pramana 29, 455.

4587. THE IMPACT OF THE PRESSURE SHIFT OF HYDROGEN LINES ON "RELATIVISTIC" MASSES OF WHITE DWARFS. Grabowski B., Madej J., Halenka J., Astrophys. J. 313,750 .

4588. COLLISION BROADENING OF THE Sr-ION RESONANCE LINE FROM THE LINE CORE TO THE NEAR-WING REGION. Harima H., Tachibana K., Urano Y., Phys. Rev. A 35,109 .

4589. SATURATION OF THE CALCIUM SINGLET RESONANCE LINE AND EXCITATION TRANSFER BY COLLISIONS WITH RARE GASES. Harris M., McHugh D. R., Lewis E. L., Shannon I., Zokai M., J. Phys. B 20, 5575.

4590. LOW-FREQUENCY ELECTRIC MICROFIELD CALCULATIONS BY ITERATIVE METHODS. Held B., Pignolet P., J. Phys. (Paris) 48, 1951.

4591. IMPROVED NON-LTE BALMER-LINE PROFILES FOR HOT STARS. Herrero A., Astron. Astrophys. 171, 189.

4592. DISPERSIVE PLASMA-SATELLITES OF A DIPOLE-FORBIDDEN TRANSITION AND THE ROTATING FIELD MODEL. Hildebrandt J., J. Quant. Spectrosc. Radiat. Transfer $37,211$.

4593. ION-COLLISION BROADENING OF SOLAR LINES IN THE FAR-INFRARED AND SUBMILLIMETER SPECTRUM. Hoang-Binh D., Brault P., Picart J., Tran Minh N., Vallée 0., Astron. Astrophys. 181, 134.

4594. ABSORPTION AND EMISSION LINE PROFILE COEFFICIENTS OF MULTILEVEL ATOMSIII. GENERALIZED ATOMIC REDISTRIBUTION FUNCTIONS FOR THREE-PHOTON PROCESSES. Hubeny I., Oxenius J., J. Quant. Spectrosc. Radiat. Transfer 37,65 . 
4595. RADIATION TRAPPING IN SODIUM - NOBLE-GAS MIXTURES. Huennekens J., Park H. J., Colbert T., McClain S. C., Phys. Rev. A 35, 2892.

4596. ASYMMETRIES IN SPECTRAL LINES DUE TO PLASMA-ION BROADENING: SOME UNUSUAL CASES AND A POSSIBLE TEST FOR PLASMA HOMOGENEITY. Jones D. W., Pichler G., Wiese W. L., Phys. Rev. A 35, 2585.

4597. COLLISIONAL BROADENING OF THE Na D LINES BY XENON IN HIGH-PRESSURE SODIUM ARCS. Jongerius M. J., J. Phys. B 20, 3345.

4598. ASYMMETRY OF STARK-BROADENED LYMAN LINES FROM LASER-PRODUCED PLASMAS. Joyce R. F., Woltz L. A., Hooper C. F. Jr., Phys. Rev. A 35, 2228.

4599. VOIGT LINESHAPE FUNCTION AS A SERIES OF CONFLUENT HYPERGEOMETRIC FUNCTIONS. Keshavamurthy R. S., J. Phys. A 20, L273.

4600. HYDRODYNAMICAL TREATMENT OF SPECTRAL BROADENING OF TURBULENT PLASMA. Khan T. P., J. App1. Phys. 62, 3062 .

4601. LASER-ABSORPTION PROFILES OF THE CALCIUM - RARE-GAS $\left(4 s^{1} \Sigma^{+}-5 s^{1} \Sigma^{+}\right)$ MOLECULAR BANDS. Kleiber P. D., Sando K. M., Phys. Rev. A 35, 3715.

4602. THE UV-VISIBLE SPECTROSCOPY OF LASER-PRODUCED ALUMINUM PLASMAS. Knudtson J. T., Green W. B., Sutton D. G., J. App1. Phys. 61, 4771.

4603. SPECTRAL-LINE BROADENING IN A PLASMA. Kogan V. I., Lisitsa V. S., Sholin G. V., "Reviews of Plasma Physics," 13, 261-234 (Ed. B. B. Kadomtsev, Consultants Bureau, New York, 1987).

4604. STARK BROADENING OF SPECTRAL LINES OF HOMOLOGOUS, DOUBLY-IONIZED INERT GASES. Konjevic N., Pittman T. L., J. Quant. Spectrosc. Radiat. Transfer 37,311 .

4605. DECONVOLUTION ALGORITHM FOR A FABRY-PEROT INTERFEROMETER. KoO J. Y., Kim J. J., App1. Opt. 26, 1094.

4606. GENERALIZED BRIDGE FUNCTIONS FOR THE REFERENCE HYPERNETTED-CHAIN EQUATION: CALCULATION OF THE ELECTRIC MICROFIELD DISTRIBUTION IN A PLASMA. Lado F., Phys. Rev. A 36, 313. 
4607. A TEGHNIQUE FOR ALMOST DOPPLER-FREE SPECTROSCOPY OF HIGHLY IONIZED ATOMS. Laming J. M., Silver J. D., Phys. Lett. A 123, 395.

4608. AUTOMATIC MULTIDiMENSiONAL DECONVOLUTiON. Lane R. G., Bates R. H. T., J. Opt. Soc. Am. B 4, 180 .

4609. DOUBLE OPTICAL RESONANCE AT HIGH PRESSURE: COLLISIONAL BROADENING AND DOPPLER EFFECTS ON AC STARK SPLITTING. Lau A. M. F., Opt. Commun. 64, 144.

4610. IMPACT BROADENING OF RYDBERG ATOMIC LEVELS IN INELASTIC COLLISIONS WITH ALKALI-METAL ATOMS. Lebedev V. S., Marchenko V. S., J. Phys. B 20, 6041.

4611. COMPARISON OF THE COLLISIONAL REDISTRIBUTION PROFILES FOR MgHe AND $\mathrm{MgH}_{2}$. Lyyra A. M., Sando K. M., Kleiber P. D., Phys. Rev. A 35, 915.

4612. ESCAPE FACTORS FOR STARK-BROADENED LINE PROFILES. Mancini R. G., Joyce R. F., Hooper C. F. Jr., J. Phys. B 20, 2975.

4613. ASYMMETRY OF THE H $\beta$ CENTRAL PART MEASURED IN A T-TUBE. Mijatovic Z., Pavlov M., Djurovic S., J. Quant. Spectrosc. Radiat. Transfer 38, 209.

4614. BROADENING OF THE $\mathrm{Ca}^{+}$INFRARED TRIPLET BY HELIUM. Monteiro T. S., Cooper I. L., Dickinson A. S., Lewis E. L., J. Phys. B 20, 741.

4615. ITERATIVE DECONVOLUTION ALGORITHM WITH QUADRATIC CONVERGENCE. Morris G. E., Richards M. A., Hayes M. H., J. Opt. Soc. Am. A 4, 200.

4616. PRESSURE BROADENING OF ARGON LINES EMITTED BY A HIGH-PRESSURE MICROWAVE DISCHARGE (SURFATRON). Moussounda P. S., Ranson P., J. Phys. B 20, 949.

4617. MEASUREMENTS OF STARK-BROADENED BALMER $\alpha$ and $\gamma$ LINES OF He II IN DENSE PLASMAS. Musielok J., Böttcher F., Griem H. R., Kunze H.-J., Phys. Rev. A $36,5683$.

4618. STARK BROADENING OF NEUTRAL AND SINGLY IONIZED GALLIUM AND INDIUM LINES. N'Dollo M., Fabry M., J. Phys. (Paris) 48, 703.

4619. OBSERVATION OF ASYMMETRIC STARK PROFILES FROM PLASMAS CREATED BY A PICOSECOND KrF LASER. Nam C. H., Tighe W., Suckewer S., Seely J. F., Feldman U., Woltz L. A., Phys. Rev.. Lett. 59, 2427. 
4620. INERT GASES' COLLISIONAL BROADENING AND SHIFT OF THALLIUM RYDBERG STATES. Naveedullah K., Nuovo Cimento D 9, 1463.

4621. CALCUlation OF HELiUm Plasma satellites in tURbulEnt Plasmas. Nee T. $-\mathrm{J}$. A., J. Quant. Spectrosc. Radiat. Transfer 38, 213.

4622. STARK WIDTHS OF Cu I AND Cu II LINES. Neger T., Jäger H., Z. Naturforsch., Teil A 42, 429.

4623. A STUDY OF COLLISIONAL BROADENING OF THE Na D LINES BY NEON AND XENON PERTURBERS: II. THE LINE WINGS. Nieuwesteeg K. J., Hollander Tj., Alkemade C. Th., J. Phys. B 20, 515.

4624. SPECTRUM AND POLARIZATION OF COLLISION-INDUCED FLUORESCENCE AND RAYLEIGH COMPONENTS OF NaD LINES AT QUASI-RESONANT EXCITATION. Nieuwesteeg K. J., Hollander Tj., Alkemade C. Th. J., J.Quant. Spectrosc. Radiat. Transfer $37,141$.

4625. A STUDY ON COLLISIONAL BROADENING OF THE NaD LINES BY NEON AND XENON PERTURBERS: I. THE LINE CORE. Nieuwesteeg K. J., Leegwater J. A., Hollander Tj., Alkemade C. Th. J., J. Phys. B 20, 487.

4626. CENTRAL STRUCTURE OF $D_{\beta}$ LINE IN LOW PRESSURE T-TUBE DEUTERIUM PLASMAS. Pavlov M., Mi jatovic Z., Contrib. Plasma Phys. 27, 113.

4627. INFLUENCE OF THE GLASS-TO-PLASMA BOUNDARY LAYERS IN A T-TUBE ON THE H $\beta$ LINE PROFILE. Pavlov M., Terzic M., J. Quant. Spectrosc. Radiat. Transfer 37,373 .

4628. QUASIRESONANT STARK BROADENING OF OPTICAL SPECTRA OF QUANTUM SYSTEMS IN A GAUSSIAN NOISE FIELD. Perel'man N. F., Averbukh I. Sh., Kovarskii V. A., Sov. Phys.--JETP 66, 276.

4629. STARK WIDTHS AND SHIFTS OF NEUTRAL NEON SPECTRAL LINES. Puric J., Cuk M., Rathore B. A., Phys. Rev. A 35, 1132.

4630. STARK WIDTHS AND SHIFTS OF Ne II SPECTRAL LINES. Puric J., Djenize S., Sreckovic A., Labat J., Cirkovic Lj. M., Phys. Rev. A 35, 2111.

4631. STARK BROADENING AND REGULARITIES OF PROMINENT MULTIPLY IONIZED NITROGEN SPECTRAL LINES. Puric J., Sreckovic A., Djenize S., Platisa M., Phys. Rev. A 36, 3957. 
4632. STUDY OF THE PRESSURE BROADENING OF THE $587.6 \mathrm{~nm}$ HELIUM AND THE $588.2 \mathrm{~nm}$ NEON LINES. Röche-Hansen J., Jess K., Helbig V., J. Phys. B 20, 4993.

4633. DETERMINATION OF THE TEMPERATURE OF A PULSED DISCHARGE FROM ASYMMETRICALLY SELF-REVERSED SPECTRAL LINES. Salakhov M. Kh., Sarandaev E. V., Latipov R. Z., Fishman I. S., High Temp. (USSR) 24, 593.

4634. MEASUREMENT OF THE ION DYNAMIC EFFECT ON THE $\mathrm{H}_{\alpha}$ AND $\mathrm{D}_{\alpha}$ LINES AT LOW ELECTRON DENSities. Sanchez A., Fulton R. D., Griem H. R., Phys. Rev. A $35,2596$.

4635. IDENTIFICATION OF NaNa SATELLITES IN THE 320-350 nm SPECTRAL REGION. Schlejen J., Woerdman J. P., de Groot J. J., J. Phys. B 20, L369.

4636. ATOMIC DATA FOR OPACITY CALCULATIONS: V. ELECTRON IMPACT BROADENING OF SOME C III LINES. Seaton M. J., J. Phys. B 20, 6431.

4637. THE WINGS OF THE CALCIUM INFRARED TRIPLET LINES IN SOLAR-TYPE STARS. Smith G., Drake J. J., Astron. Astrophys. 181, 103.

4638. A UNIFIED PRESENTATION OF THE VOIGT FUNCTIONS. Srivastava H. M., Miller E. A., Astrophys. Space Sci. 135, 111.

4639. ON TIME-DEPENDENT RADIATIVE TRANSFER. Streater A., Cooper J., Sandle W., J. Quant. Spectrosc. Radiat. Transfer 37, 151.

4640. RESONANT-RADIATION TRANSFER WITH PARTIAL REDISTRIBUTION IN FREQUENCY. Suvorov A. E., Sov. Phys.--JETP 65, 251.

4641. PARTIAL REDISTRIBUTION IN HIGH-DENSITY, HIGHLY IONIZED PLASMAS. Talin B., Stamm R., Kaftandjian V. P., Klein L., Astrophys. J. 322, 804.

4642. PRESSURE SHIFTS AND BROADENINGS OF Rb RYDBERG STATES BY Ne, $\mathrm{Kr}$ AND $\mathrm{H}_{2}$. Thompson D. C., Kammermayer E., Stoicheff B. P., Weinberger E., Phys. Rev. A 36, 2134.

4643. FREQUENCY SHIFTS AND LINE BROADENINGS IN COLLISIONS BETWEEN RYDBERG AND GROUND-STATE ALKALI-METAL ATOMS. Thompson D. C., Weinberger E., Xu G.-X., Stoicheff B. P., Phys. Rev. A 35, 690. 
4644. DOPPLER-FREE SPECTROSCOPY BASED ON PHASE CONJUGATION BY DEGENERATE FOUR-WAVE MIXING IN HOLLOW CATHODE DISCHARGE. Tong W. G., Chen D. A., Appl. Spectrosc. 41, 586.

4645. BROADENING AND SHIFT OF THULIUM AND SAMARIUM RESONANCE LINES BY KRYPTON. Vedenin V. D., Opt. Spectrosc. (USSR) 63, 708.

4646. THE J DEPENDENCE OF COLLISIONAL BROADENING FOR FINE-STRUCTURE COMPONENTS OF Sm I. Vedenin V. D., Kulyasov V. N., Kurbatov A. L., Rodin N. V., Shubin M. V., Opt. Spectrosc. (USSR) 62, 439.

4647. HYPERFINE CONTRIBUTION TO SPIN-EXCHANGE FREQUENCY SHIFTS IN THE HYDROGEN LASER. Verhaar B. J., Koelman J. M. V. A., Stoof H. T. C., Luiten O. J., Crampton S. B., Phys. Rev. A 35, 3825.

4648. EXPERIMENTAL STUDY OF $\mathrm{H}_{\alpha}$ BROADENING AND SHIFT IN DENSE ARGON PLASMAS. Vitel Y., J. Phys. B 20, 2327.

4649. NOBLE GAS LINE PROFILES IN DENSE PLASMAS: I. ARGON. Vitel Y., Skowronek M., J. Phys. B 20, 6477 .

4650. NOBLE GAS LINE PROFILES IN DENSE PLASMAS: II. KRYPTON AND XENON. Vitel Y., Skowronek M., J. Phys. B 20, 6493.

4651. BROADENING AND SHIFT OF THE T1 6 $\mathrm{P}_{1 / 2}-7 \mathrm{P}_{1 / 2,3 / 2}$ TWO-PHOTON LINES PERTURBED BY NOBLE GASES. von Borstel M., Hermann G., Lasnitschka G., Scharmann A., Z. Phys. D 4, 383.

4652. PRESSURE EFFECTS ON SOME ARGON SPECTRAL LINES BELONGING TO THE $3 p^{5} 4 p-3 p^{5}$ nd $(\mathrm{n}=5-7)$ TRANSITIONS. Wolnikowski J., Wawrzynski J., Bielski A., Szudy J., Phys. Scr. 35, 153.

4653. SPECTRAL LiNe PROFile of TURbUlENT GAS. Zhi G., Qian J., Appl. Opt. 26, 1579 .

4654. PRESSURE BROADENING OF THE $\mathrm{Ba}^{+}$RESONANCE DOUBLET BY HELIUM AND ARGON. Zokai M., Harris M., Shannon I., Szebesta D., McHugh D. R., Lewis E. L., J. Phys. B 20, 4393. 
4655. STARK CONSTANT OF Ar I LINES. Abbas A., Basha T. S., Abd E1-Aal Z. A., Nuovo Cimento D 10, 597.

4656. STARK BROADENING OF Ar I LINES. Abbas A., Basha T. S., Abdel-Aal Z. A., Jpn. J. Appl. Phys. Pt. 1, 27, 801.

4657. HALF-WIDTH, SHIFT AND TRANSITION PROBABILITY OF AR II LINES. Abbas A., Basha T. S., Abdel-Aal Z. A., Jpn. J. Appl. Phys. Pt. 1, 27, 804.

4658. ANALYSIS OF THE FAR-WING BEHAVIOR IN THE SPECTRUM OF THE LIGHT-INDUCED COLLISIONAL-ENERGY-TRANSFER PROCESS. Agresti A., Berman P. R., Bambini A., Stefanel A., Phys. Rev. A38, 2259.

4659. COLLISION-BROADENED SPECTRAL LINE PROFILES IN THE LIMIT OF HIGH PERTURBER DENSITY. Allard N. F., Biraud Y. G., Chevillot A., Phys. Rev. A 37, 1479.

4660. DEMULTIPLICATION EFFECT OF SATELLITE LINES IN COLLISION-PERTURBED LINE PROFIlES. Allard N. F., Prud'homme M., Ann. Phys. (Paris) 13, Colloq. 1, 73. (Fr.)

4661. SHAPES OF ATOMIC-HYDROGEN LINES PRODUCED AT A CATHODE SURFACE. Ayers E. L., Benesch W., Phys. Rev. A 37, 194.

4662. STARK BROADENING IN HIGH ANGULAR MOMENTUM STATES OF ATOMIC OXYGEN: APPLICATION TO TRANSITIONS BETWEEN 5.5 and $8.0 \mu \mathrm{m}$. Baird J. C., Alexiou S., Chem. Phys. Lett. 152, 124.

4663. TEMPERATURE EFFECTS IN THE COLLISIONAL REDISTRIBUTION OF RESONANCE RADIATION IN THE Ba-Ar AND Ba-Xe SYSTEMS. Belsley M. S., Coutts J., Cooper J., Phys. Rev. A 38, 3781.

4664. CONTRIBUTION OF THE ZEEMAN EFFECT TO MEASURED LINE PROFILES EMITTED BY ALCATOR-C PLASMAS. Benjamin R. D., Terry J. L., Moos H. W., Phys. Rev. A $37,537$.

4665. ELECTRON COLLISION SHIFT OF THE LYMAN- $\alpha$ LINE IN H AND He ${ }^{+}$. Blaha M., Davis J., NRL Memorandum Report 6294 (1988). 
4666. IMPACT BROADENING OF SPECTRAL LINES CORRESPONDING TO TRANSITIONS BETWEEN EXCITED LEVELS OF THE CESIUM ATOM. Bogdanov Yu. V., Kanorskii S. I., Papchenko A. A., Sobel'man I. I., Sorokin V. N., Struk I. I., Yukov E. A., Opt. Spectrosc. (USSR) 65, 487.

4667. OSCILLATIONS IN THE BROADENING OF RYDBERG LEVELS DURING ASSOCIATIVE IONIZATION. Borodin V. M., Kazanskii A. K., Opt. Spectrosc. (USSR) 65, 490 .

4668. BROADENING AND SHIFT OF THALLIUM $n \mathrm{nP}_{1 / 2,3 / 2}$ STATES $(\mathrm{n}=6-10)$ PERTURBED BY NOBLE GASES. Borstel M. v., Hermann G., Lasnitschka G., Z. Phys. D 9, 15.

4669. DEPENDENCE OF THE STARK BROADENING ON THE EMITTER CHARGE FOR THE $3 \mathrm{~s}-3 \mathrm{p}$ TRANSITIONS OF Li-LIKE IONS. Böttcher F., Breger P., Hey J. D., Kunze H. - J., Phys. Rev. A 38, 2690.

4670. INTENSITY AND SHAPE OF LASER-PLASMA-EMITTED HYDROGENIC AND HELIUMLIKE ALUMINUM SPECTRAL LINES. Bousquet C., Grumberg J., Leboucher E., Nguyen Hoe, Poquerusse A., Ann. Phys. (Paris) 13, Colloq. 1, 77.(Fr.)

4671. EXPERIENCE WITH MEASURING OF THE SPECTRAL LINE PROFILE BY MEANS OF THE FABRY-PEROT INTERFEROMETER. Brablec A., Kapicka V., Stastny F., Contrib. Plasma Phys. 28, 221.

4672. COLLISION BROADENING OF SOLAR RYDBERG LINES IN THE FAR INFRARED AND SUBMILLIMETER REGIONS. Brault P., Hoang-Binh D., Picart J., Tran Minh N., Vallee 0., Ann. Phys. (Paris) 13, Colloq. 1, 81.(Fr.)

4673. LINE SHAPES IN RESONANCE FLUORESCENCE FOR EXTERNAL SOURCES NEAR UNIT OPTICAL DEPTH. Brooks W. S. C., Kendall D. J. W., Llewellyn E. J., McDade I. C., Can. J. Phys. 66, 93.

4674. RADIATION TRANSPORT IN SPECTRAL LINES. Bulyshev A. E., Preobrazhenskii N. G., Suvorov A. E., Sov. Phys.--Usp. 31, 865.

4675. SIMULATION CALCULATION OF THE ION-DYNAMIC EFFECTS ON OVERLAPPING NEUTRAL HELIUM LINES. Calisti A., Stamm R., Talin B., Phys. Rev. A38, 4883.

4676. BLUE-WING PROFILE FOR THE HYDROGEN LYMAN- $\alpha$ LINE. Chambaud G., Archirel P., Levy B., Ann. Phys. (Paris) 13, Colloq. 1, 85.(Fr.) 
4677. EFFICIENT CALCULATION OF GENERAL VOIGT PROFIlES. Cope D., Khoury R., Lovett R. J., J. Quant. Spectrosc. Radiat. Transfer 39, 163.

4678. ASYMPTOTIC COEFFICIENTS FOR ONE-INTERACTING-LEVEL VOIGT PROFILES. Cope D., Lovett R. J., J. Quant. Spectrosc. Radiat. Transfer 39, 173.

4679. THE HYDROGEN BALMER SPECTRUM IN THE NEAR-THRESHOLD REGION: UNIFIED SEMICLASSICAL CALCULATION OF LINE AND CONTINUUM CONTRIBUTIONS. D'yachkov L. G., Kobzev G. A., Pankratov P. M., J. Phys. B 21, 1939.

4680. PROCESSING OF SPECTRAL LINE PROFILES AND DETERMINATION OF DISTRIBUTION FUNCTIONS OF EXCITED ATOMS IN A NONEQUILIBRIUM RF DISCHARGE. Deinezhenko A. L., Protasevich E. T., Opt. Spectrosc. (USSR) 65, 303.

4681. INTERACTION OF Eu $\left(4 \mathrm{f}^{7} 6 \mathrm{~s} 6 \mathrm{py}^{8} \mathrm{P}_{\mathrm{J}}\right)$ ATOMS WITH INERT-GAS ATOMS. Devdariani A. Z., Sebyakin Yu. N., Opt. Spectrosc. (USSR) 65, 484.

4682. LINE SHIFTS OF $\mathrm{Kr}$ II, $\mathrm{Kr}$ III, and $\mathrm{Xe}$ III IN HIGH-CURRENT, PINCHED DISCHARGES. Di Rocco H. O., Bertuccelli G., Reyna Almandos J., Bredice F., Gallardo M., J. Quant. Spectrosc. Radiat. Transfer 40, 513.

4683. ON THE COMBINED DOPPLER AND PRESSURE BROADENING OF NONRESONANT SPECTRAL LINES. Diaz M. A., Palomares F., Veguillas J., Can. J. Phys. 66, 341.

4684. ELECTRON-IMPACT WIDTHS OF DOUBLY AND TRIPLY CHARGED ION LINES OF ASTROPHYSICAL IMPORTANCE. Dimitrijevic M. S., Astron. Astrophys., Suppl. Ser. $76,53$.

4685. COMPARISON BETWEEN DIFFERENT APPROXIMATE APPROACHES FOR THE CALCULATION OF STARK WIDTHS OF DOUBLY - AND TRIPLY - CHARGED ION LINES OF ASTROPHYSICAL IMPORTANCE. Dimitrijevic M. S., Bul1. Obs. Astron. Belgrade No. 139,31 .

4686. ON THE STARK BROADENING OF C IV LINES. Dimitrijevic M. S., Bull. Obs. Astron. Belgrade No. 139, 70 .

4687. STARK BROADENING AND SHIFT OF MULTIPLY IONIZED CARBON SPECTRAL LINES. Djenize S., Sreckovic A., Milosavl jevic M., Labat O., Platisa M., Puric J., Z. Phys. D 9, 129 . 
4688. STARK SHIFT AND BROADENING OF F I and Cl I LINES. Djurovic S., Konjevic N., Z. Phys. D 10, 425.

4689. STARK BROADENING AND SHIFT OF NEUTRAL BROMINE LINES. D jurovic S., Konjevic R., Platisa M., Konjevic N., J. Phys. B 21, 739.

4690. THE $\mathrm{H}_{\beta}$ LINE DIP SHIFT. Djurovic S., Mijatovic Z., Kobilarov R., Contrib. Plasma Phys. 28, 229.

4691. BROADENING AND SHIFT OF THE RESONANCE LINE OF THALLIUM DUE TO COLLISIONS WITH KRYPTON AND XENON ATOMS. Dygdala R. S., J. Phys. B 21, 2039.

4692. PRESSURE EFFECTS OF KRYPTON AND XENON ON THE $535 \mathrm{~nm}$ THALLIUM LINE. Dygdala R. S., Lisicki E., Phys. Scr. 37, 38.

4693. FURTHER STUDIES ON THE INFLUENCE OF PRESSURE ON SPECTRAL LINE OVERLAPS IN ELECTROTHERMAL ATOMIC ABSORPTION SPECTROMETRY. Fazakas J., Zugravescu P. Gh., Spectrochim. Acta, Part B 43, 897.

4694. SPECIFIC FEATURES OF STARK BROADENING OF HELIUM-LIKE MULTI-CHARGED ION SPECTRAL LINES. Gavrilenko V. P., Gaisinsky I. M., Ispolatov Ya. O., Oks E. A., J. Phys. (Paris) 49 Colloq. 1, 83.

4695. He II P $\alpha$ STARK BROADENING AND INTENSITY RADIO OF C IV AND C III LINES CALIBRATED WITH THOMSON SCATTERING FOR HIGH-DENSITY PLASMA DIAGNOSTICS. Gawron A., Maurmann S., Böttcher F., Meckler A., Kunze H. J., Phys. Rev. A38, 4737 .

4696. PLASMA SHIFTS OF ION LINES. Griem H. R., J. Phys. (Paris) Colloq. 49, C1 -293 .

4697. SHIFTS OF HYDROGEN AND IONIZED-HELIUM LINES FROM $\mathrm{n}=0$ INTERACTIONS WITH ELECTRONS IN DENSE PLASMAS. Griem H. R., Phys. Rev. A 38, 2943.

4698. DOPPLER-FREE TWO-PHOTON POLARIZATION SPECTROSCOPY OF THE STARK-BROADENED HYDROGEN L- $\alpha$ LINE IN A DENSE PLASMA. Grützmacher K., Seidel J., Ann. Phys. (Paris) 13, Colloq. 1, 123.

4699. ASYMMETRY OF THE PEAKS OF THE H $\beta$ SPECTRAL LINE. Halenka J., J. Quant. Spectrosc. Radiat. Transfer 39, 347. 
4700. PRESSURE SHIFT AND BROADENING OF Sr I RYDBERG STATES IN NOBLE GASES. Heber K.-D., West P. J., Matthias E., Phys. Rev. A 37, 1438.

4701. COLLISION-TIME SIMULATION TECHNIQUE FOR PRESSURE-BROADENED SPECTRAL LINES WITH APPLICATIONS TO Ly- $\alpha$. Hegerfeldt G. C., Kesting V., Phys. Rev. A 37, 1488 .

4702. ITERATIVE METHOD OF CALCULATING THE IONIC MICROFIELD. Held B., Pignolet P., Ann. Phys. (Paris) 13, Colloq. 1, 125.(Fr.)

4703. COLLISIONAL BROADENING AND SHIFT OF FINE-STRUCTURE STATES WITH INTERMEDIATE PRINCIPAL QUANTUM NUMBERS. Hermann G., Phys. Lett. A 133, 225 .

4704. RELATIONSHIP BETWEEN KINETIC THEORY AND GREEN'S-FUNCTION APPROACH WITH RESPECT TO ELECTRON SHIFT AND THE BROADENING OF SPECTRAL LINES. Hitzschke L., Röpke G., Phys. Rev. A 37, 4991.

4705. OBSERVATION OF BALMER-ALPHA LINE PROFILE OF HYDROGEN ATOMS IN PLASMAS BY RAPID-FREQUENCY-SCAN LASER SPECTROSCOPY. Honda C., Maeda M., Uchino K., Muraoka K., Akazaki M., Jpn. J. Appl. Phys. Part $127,635$.

4706. PRECISION MEASUREMENT OF THE STARK SHIFT OF THE CESIUM D LINES. Hunter L. R., Krause D. Jr., Murthy S., Sung T. W., Phys. Rev. A 37, 3283.

4707. ION-MOTION BROADENING OF THE $n=0, n=2$ TRANSITIONS OF $C V$ IN A CARBON LASER-PRODUCED PLASMA. Iglesias E. J., Griem H. R., Phys. Rev. A 38, 301.

4708. LINE-BROADENING MEASUREMENTS OF $\mathrm{H}_{\alpha}, \mathrm{H}_{\beta}$, AND $\mathrm{L}_{\delta}$ OF $\mathrm{C}$ VI IN A LASER-PRODUCED CARBON PLASMA. Iglesias E. J., Griem H. R., Phys. Rev. A 38,308 .

4709. STARK BROADENING OF SPECTRAL LINES IN SOME N II and C III MULTIPLETS IN Z-PINCH PLASMA. Istrefi L., Rev. Roum. Phys. 33, 667.

4710. CALCULATION OF THE SPECTRAL PROFILE FOR ISOLATED ATOMIC LINES IN PLASMAS. Kissami H., Fleurier C., Ann. Phys. (Paris) 13, Colloq.1, 133.(Fr.)

4711. PLASMA SHIFT OF THE He II $\mathrm{P}_{\alpha}$ LINE. Kobilarov R., Popovic M. V., Konjevic N., Phys. Rev. A 37, 1021. 
4712. ATOMIC STRUCTURE AND LINE BROADENING OF He-LIKE IONS IN HOT AND DENSE PLASMAS. Koenig M., Malnoult P., Nguyen Hoe, Phys. Rev. A 38, 2089.

4713. DENSITY EFFECTS IN LASER-PLASMA-EMITTED SPECTRA. Koenig M., Nguyen Hoe, Ann. Phys. (Paris) 13 Colloq. 1, 49.(Fr.)

4714. ASYMMETRIC LINE PROFILES OF HIGHLY CHARGED IONS IN DENSE PLASMAS AND DiELECTRONiC SATEllites. Koshelev K. N., J. Phys. B 21, L593.

4715. STARK BROADENING OF VISIBLE Si II LINES IN STELLAR ATMOSPHERES. Lanz T., Dimitrijevic M. S., Artru M. C., Astron. Astrophys. 192, 249.

4716. THE EFFECT OF SPECTRAL LINE BROADENING ON THE SHAPE OF ANALYTICAL CURVES OBTAINED USING PULSED HOLLOW-CATHODE LAMPS FOR BACKGROUND CORRECTION. Larkins P. L., Spectrochim. Acta, Part B 43, 1175.

4717. PLASMA LINE SHAPES FOR SELECTED TRANSITIONS IN HYDROGEN-, HELIUM- AND LITHIUM-LIKE IONS. Lee R. W., J. Quant. Spectrosc. Radiat. Transfer 40, 561 .

4718. FULLY ADIABATIC INTERPRETATION OF FINE-STRUCTURE CHANGING TRANSITIONS IN COLLISIONS OF ALKALI ATOMS IN ${ }^{2} \mathrm{P}$ ELECTRONIC STATES WITH NOBLE GAS.

Lemoine D., Robbe J. M., Pouilly B., J. Phys. B 21, 1007.

4719. SOME PECULIARITIES IN STARK BROADENING OF SPECTRAL LINES OF HYDROGEN-LIKE IONS IN A DENSE PLASMA. Ljublin B. V., Yasevich V. Yu., Yakolev D. G., Laser Part. Beams 6, Pt. 2, 377.

4720. THE EFFECTIVE RANGE OF INTERATOMIC POTENTIALS IN COLLISION BROADENING. Lobb W. S., McCartan D. G., J. Phys. B 21, L723.

4721. THERMODYNAMIC PARAMETERS AND DISTRIBUTIONS OF INSTANTANEOUS VALUES OF MICROFIELDS IN A NONIDEAL PLASMA. Maiorov S. A., Tkachev A. N., Yakovlenko S. I., Sov. Phys.--Dokl. 33, 212.

4722. STARK BROADENING OF THE SINGLY IONIZED XENON LINE: TEMPERATURE VARIATION. Manola S., Konjevic N., Richou J., Lebrun J. L., Lesage A., Phys. Rev. A 38,5742 .

4723. He II BALMER SERIES LINE SHIFTS IN A DENSE z-PINCH PLASMA. Marangos J. P., Burgess D. D., Baldwin K. G. H., J. Phys. B $21,3357$. 
4724. THEORY OF THE POLARIZATION SHIFT OF QUANTUM LEVELS. Marchenko V. S., Sov. Phys.--JETP 67, 1111.

4725. APPLICATION OF OPTOGALVANIC SPECTROSCOPY TO THE MEASUREMENT OF PRESSURE BROADENING AND SHIFT IN THE NEGATIVE GLOW REGION OF AN Ar HOLLOW CATHODE DISCHARGE. Masaki T., Adachi Y., Hirose C., Appl. Spectrosc. 42, 54.

4726. RESPONSE FUNCTION OF A TUNABLE DIODE LASER SPECTROMETER FROM AN ITERATIVE DECONVOLUTION PROCEDURE. May R. D., J. Quant. Spectrosc. Radiat. Transfer $39,247$.

4727. NUMERICAL EVALUATION OF THE LINE BROADENING FUNCTION H (a,v). Milone A. A. E., Milone L. A., Bobatto G. E., Astrophys. Space Sci. 147, 229.

4728. BROADENING AND SATURATION OF IODINE-127 R(127) $11-5$ LINE $(0.63299 \mu \mathrm{m})$ IN A HELIUM-NEON LASER. Mironov A. V., Opt. Spectrosc. (USSR) 65, 471.

4729. BROADENING OF THE $\mathrm{Ca}^{+}$AND $\mathrm{Mg}^{+}$RESONANCE LINES BY COLLISION WITH ATOMIC HYDROGEN. Monteiro T. S., Danby G., Cooper I. L., Dickinson A. S., Lewis E. L., J. Phys. B 21, 4165 .

4730. MEASUREMENTS OF SOME PLASMA-BROADENED Ge I SPECTRAL LINE PROFILES. Musiol K., Labuz S., Pokrzywka B., J. Quant. Spectrosc. Radiat. Transfer 40, 143.

4731. THE INFLUENCE OF REALISTIC VELOCITY-DEPENDENT CROSS SECTIONS ON THE CORRELATION BETWEEN DOPPLER AND COLLISIONAL BROADENING OF THE Na $\mathrm{D}_{1}$ SPECTRAL LINE. Nieuwesteeg K. J. B. M., J. Phys. B 21, 1353.

4732. COLLISIONAL BROADENING OF THE BALMER $-\alpha$ TRANSITIONS OF $\mathrm{H}$ and $\mathrm{He}^{+}$IN Plasmas. Oza D. H., Greene R. L., Kelleher D. E., Phys. Rev. A37, 531.

4733. DEPENDENCE OF THE HALF WIDTHS OF PLASMA-BROADENED HYDROGEN LINES ON REDUCED MASS, TEMPERATURE, AND DENSITY. Oza D. H., Greene R. L., Kelleher D. E., Phys. Rev. A 38, 2544.

4734. COMMENT ON COLLISIONAL BROADENING OF THE $\mathrm{H}_{\alpha}$ LINE IN DENSE PLASMAS. Oza D. H., Greene R. L., J. Phys. B 21, L5.

4735. SELF-ABSORPTION IN COPPER HOLLOW CATHODE DISCHARGES: EFFECTS ON SPECTRAL LINE SHAPE AND ABSORPTION SENSITIVITY. Phillips H. A., Lancaster H. L., Denton M. B., Rozsa K., Apai P., Appl. Spectrosc. 42, 572. 
4736. STARK-BROADENING REGULARITIES OF LITHIUM-LIKE AND SODIUM-LIKE ISOELECTRONIC SEQUENCES. Puric J., Djenize S., Labat J., Platisa M., Sreckovic A., Cuk M., Z. Phys. D 10, 431.

4737. STARK-BROADENING REGULARITIES OF PROMINENT MULTIPLY-IONIZED OXYGEN SPECTRAL LINES IN PLASMA. Puric J., Djenize S., Sreckovic A., Platisa M., Labat J., Phys. Rev. A 37, 498.

4738. STARK BROADENING AND REGULARITIES OF IONIZED NEON AND ARGON SPECTRAL LINES. Puric J., Djenize S., Sreckovic A., Cuk M., Labat J., Platisa M., Z. Phys. D 8, 343.

4739. REGULARITIES IN NEUTRAL AND ION LINE STARK BROADENING IN PLASMA. Puric J., Djenize S., Sreckovic A., Cuk M., Fizika (Zagreb) 20, 485.

4740. STARK BROADENING AND REGULARITIES OF PROMINENT SPECTRAL LINES OF MULTIPLY IONIZED CHLORINE AND FLUORINE. Puric J., Sreckovic A., Djenize S., Platisa M., Phys. Rev. A 37, 4380.

4741. STARK WIDTHS AND SHIFTS OF SEVERAL PROMINENT Ne I SPECTRAL LINES. Puric J., Sreckovic A., Djenize S., Labat J., Cirkovic Lj. M., Phys. Lett. A. 126,280 .

4742. PRESSURE BROADENING AND LASER-INDUCED SPECTRAL LINE SHAPES. Sando K. M., Chu S.-I, Adv. At. Mol. Phys. 25, 133.

4743. SPECTROMETRIC SETUP WITH A CAPILLARY LIGHT SOURCE FOR INVESTIGATING THE STARK BROADENING OF SPECTRAL LINES. Sarandaev E. V., Salakhov M. Kh., Fishman I. S., J. Appl. Spectrosc. (USSR) 48, 343.

4744. INVESTIGATION OF COLLISIONAL LINESHAPES OF NEON TRANSITIONS IN NOBLE GASES MIXTURES. Sasso A., Tino G. M., Inguscio M., Beverini N., Francesconi M., Nuovo Cimento Soc. Ital. Fis. D 10, 941.

4745. ATOMIC DATA FOR OPACITY CALCULATIONS: VIII; LINE-PROFILE PARAMETERS FOR 42 TRANSITIONS IN Li-LIKE AND Be-LIKE IONS. Seaton M. J., J. Phys. B 21, 3033 .

4746. LEVEL BROADENING CROSS SEGTIONS FOR $\mathrm{nP}_{1 / 2}$ RYDBERG STATES OF $\mathrm{Na}, \mathrm{K}$ and $\mathrm{Rb}$ ATOMS. Sirko L., Rosinski K., J. Phys. B 21, 2585. 
4747. COLLISIONAL BROADENING OF THE CALCIUM INFRARED TRIPLET LINES BY ATOMIC HYDROGEN. Smith G., Drake J. J., Mon. Not. R. Astron. Soc. 231, 115.

4748. UNIFIED PROFILE FOR THE HYDROGEN LYMAN $\alpha$ LINE IN LOW-DENS ITY PLASMAS. Stehlé C., Ann. Phys. (Paris) 13, Colloq. 1, 155.(Fr.)

4749. TRANSFER AND REDISTRIBUTION OF POLARIZED LIGHT IN RESONANCE LINES. I. QUANTUM FORMULATION WITH COLLISIONS. Streater A., Cooper J., Rees D. E., Astrophys. J. 335, 503.

4750. EXPERIMENTS ON TIME-DEPENDENT RADIATIVE TRANSFER IN A SPECTRAL LINE. Streater A., Molander W., Cooper J., J. Quant. Spectrosc. Radiat. Transfer 40, 101.

4751. PRECISION MEASUREMENT OF THE STARK SHIFT IN THE $6 \mathrm{~S}_{1 / 2}-6_{3 / 2}$ CESIUM TRANSITION USING A FREQUENCY-STABILIZED LASER DIODE. Tanner C. E., Wieman C., Phys. Rev. A 38, 162 .

4752. THEORY OF SPECTRAL-LINE WIDTH FUNCTIONAL SENSITIVITY TO INTERACTION POTENTIAL. Vallee 0., Rabitz H., Ann. Phys. (Paris) 13, Colloq. 1, 57.( Fr. )

4753. BINARY CORRELATIONS IN SPECTRAL LINE BROADENING THEORY AND COLLISIONAL REDISTRIBUTION. Van Regemorter H., Ann. Phys. (Paris) 13, Colloq. 1, 53 (1988).(Fr.)

4754. VELOCITY DEPENDENCE OF IMPACT LINE-BROADENING STUDIED BY RESONANT DOPPLER-FREE TWO-PHOTON LASER SPECTROSCOPY. Veza D., Lawrenz J., Niemax K., Z. Phys. D 9, 135.

4755. STARK EFFECT IN PLASMAS WITH STRONG CORRELATION. Vitel Y., Skowronek M., Ann. Phys. (Paris) 13, Colloq. 1, 171.(Fr.)

4756. STARK BROADENING ALONG A HOMOLOGOUS SEQUENCE OF NOBLE GAS ATOMIC LINES IN DENSE PLASMAS. Vitel Y., Skowronek M., Dimitrijevic M. S., Popovic M. M., Astron. Astrophys. 200, 285.

4757. LASER SPECTROSCOPIC MEASUREMENTS OF THE STARK SHIFT OF THE Ne I LINES AT 5852 AND 5882 \&. Windholz L., Neureiter C., Phys. Rev. A 37, 1978. 
4758. PLASMA BROADENING OF L-SHELL SPECTRA FROM MULTI-ELECTRON IONS IN DENSE PLASMAS. Woltz L. A., Hooper C. F. Jr., "Atomic Processes in Plasmas," IAP Conference Proceedings No. 168, 15-24 (1988).

4759. CALCULATIONS OF SPECTRAL LINE PROFILES OF MULTIELECTRON EMITTERS IN PLASMAS. Woltz L. A., Hooper C. F. Jr., Phys. Rev. A 38, 4766.

4760. COLLISION-INDUCED SHIFT AND BROADENING OF TWO-PHOTON LINES OF Mg I. Zhang J.-Y., Zhou H.-T., Li Q.-R, Yang J., J. Phys. B 21, 581.

4761. AN IMPROVED VOIGT LINE APPROXIMATION FOR THE CALCULATIONS OF EQUIVALENT WIDTH AND TRANSMISSION. Zhu X., J. Quant. Spectrosc. Radiat. Transfer $39,421$.

4762. EXTENSION OF DIAGNOSTIC METHODS OF STARK SPECTROSCOPY TO HYDROGEN AND HELIUM PLASMAS OF MODERATE DENSITY. Aferenko E. V., Gaisinskii I. M., Oks E. A., Opt. Spectrosc. (USSR) 66, 452.

4763. SUPPRESSION OF THE LINE BROADENING BY FAST RABI FLOPPING EFFECTS. Agarwal G. S., Singh S., Phys. Rev. A 39, 2239.

4764. AN INVESTIGATION OF LOCAL THERMODYNAMIC EQUILIBRIUM IN AN ARGON PLASMA JET AT ATMOSPHERIC PRESSURE. Bakshi V., Kearney R. J., J. Quant. Spectrosc. Radiat. Transfer 41, 369.

4765. NEW TABles OF THE VOIGT FUnCtion. Bakshi V., Kearney R. J., J. Quant. Spectrosc. Radiat. Transfer 42, 111.

4766. MEASUREMENT OF STARK WIDTH OF SOME AR I TRANSITIONS IN A D.C. ARGON PLASMA JET AT ATMOSPHERIC PRESSURE. Bakshi V., Kearney R. J., J. Quant. Spectrosc. Radiat. Transfer 42, 405.

4767. DENSITY-SENSITIVE ALLOWED AND FORBIDDEN DIELECTRONIC SATELLITE LINE PROFILES IN LASER-PRODUCED PLASMAS. Banon J. M., Sanchez-Soto L. L., Bernabeu E., J. Phys. B 22, 199.

4768. ION-MICROFIELD-INDUCED EFFECTS ON THE SATELLITE LINE SPECTRA FROM LASER-PRODUCED PLASMAS. Banon J. M., Sanchez-Soto L. L., Bernabeu E., J. Phys. B 22, L309. 
4769. STUDY OF THE $4 f^{6} 6 s^{2} 7 \mathrm{~F}-4 \mathrm{f}^{6} 6 \mathrm{~s}^{2}{ }^{5} \mathrm{D}$ FORBIDDEN TRANSITIONS OF ATOMIC SAMARIUM. Barkov L. M., Zolotarev M. S., Melik-Pashaev D. A., Opt. Spectrosc. (USSR), 66, 288 .

4770. STARK-BROADENING OF Ar I LINES. BASHA T. S., Abdel-Aal Z. A., Acta Phys. Pol. A 75, 565 .

4771. COLLISION BROADENING OF SPECTRAL LINES OF ATOMS IN MICROWAVE FIELDS. Beilin E. L., Zon B. A., Opt. Spectrosc. (USSR) 66, 585.

4772. STUDY OF IMPACT BROADENING OF SPECTRAL LINES CORRESPONDING TO TRANSITIONS BETWEEN THE EXCITED LEVELS OF A CESIUM ATOM. Bogdanov Yu. V., Kanorskii S. I., Papchenko A. A., Sobel'man I. I., Sorokin V. N., Struk I. I., Yukov E. A., Tr. Fiz. Inst. im. P. N. Lebedeva, Akad. Nauk SSSR 195, $217 .($ Russ.)

4773. ION TEMPERATURE MEASUREMENT FROM DOPPLER BROADENING OF He-LIKE NICKEL LINES. Bombarda F., Giannella R., Källne E., Tallents G. J., J. Quant. Spectrosc. Radiat. Transfer 41, 323.

4774. DECONVOLUTION THEOREM IN FAST OPTICAL SPECTROSCOPY. Capek V., Jelinek o., Czech. J. Phys. B 39, 218.

4775. COMPUTER-SIMULATION TECHNIQUE APPLIED TO THE STUDY OF HYDROGEN STARK BROADENING BY PLASMAS. Cardenoso V., Gigosos M. A., Phys. Rev. A 39, 5258.

4776. DETERMINATION OF ELECTRON NUMBER DENSITY VIA STARK BROADENING WITH AN IMPROVED ALGORITHM. Chan S.-K, Montaser A., Spectrochim. Acta, Part B 44, 175; 44, 737 (1989).

4777. DESTRUCTION TERMS IN NON-MARKOVIAN COLLISIONAL REDISTRIBUTION. Cooper J., Phys. Rev. A 39, 409.

4778. APPROXIMATE FORMULATION OF REDISTRIBUTION IN THE Ly $\alpha$, Ly $\beta$, H $\alpha$ SYSTEM. Cooper J., Ballagh R. J., Hubeny I., Astrophys. J. 344, 949.

4779. BROADENING AND SHIFT OF SPECTRAL LINES IN ATOMIC COLLISIONS IN INERT-GAS MIXTURES. Devdariani A. Z., Zagrebin A. L., Opt. Spectrosc. (USSR) 67, 142 . 
4780. A SIMPLE RELATION BETWEEN LINE SHIFTS AND ATOMIC PARAMETERS. Di Rocco H. O., Spectrosc. Lett. 22, 1019.

4781. LINE SHIFTS OF $\mathrm{Kr}$ II, $\mathrm{Kr}$ III, AND Xe III IN HIGH-CURRENT, PINCHED DISCHARGES. Di Rocco H. O., Bertuccelli G., Reyna Almandos J., Bredice F., Gallardo M., J. Quant. Spectrosc. Radiat. Transfer 41, 161.

4782. STARK BROADENING IN ASTROPHYSICS. Dimitrijevic M. S., Bull. Obs. Astron. Belgrade No. 140, 111 .

4783. ELECTRON-IMPACT BROADENING OF Cu IV LINES FOR THE DIAGNOSTIC OF THE ARC PLASMA OF ELECTRODYNAMIC MACRO-PARTICLE ACCELERATOR. Dimitrijevic M. S., Juric Z. D., Mihajlov A. A., J. Phys. (Paris), Colloq. C1, 50, 623.

4784. ON THE INFLUENCE OF DEBYE SHIELDING ON THE STARK BROADENING OF ION LINES WITHIN THE CLASSICAL MODEL. Dimitrijevic M. S., Mihajlov A. A., Djuric Z., Grabowski B., J. Phys. B 22, 3845.

4785. ESTIMATES OF STARK WIDTH ALONG A HOMOLOGOUS SEQUENCE. Dimitrijevic M. S., Popovic M. M., Astron. Astrophys. 217, 201.

4786. TABLES FOR He I LINES STARK BROADENING PARAMETERS. Dimitrijevic M. S., Sahal-Bréchot S., Bull. Obs. Astron. Belgrade No. 141, 57.

4787. STARK BROADENING AND SHIFT OF SINGLY-IONIZED ARGON SPECTRAL LINES IN HIGHER MULTIPLETS. Djenize S., Malesevic M., Sreckovic A., Milosavljevic M., Puric J., J. Quant. Spectrosc. Radiat. Transfer 42, 429.

4788. STARK BROADENING AND SHIFT OF NEUTRAL IODINE LINES AND REGULARITIES FOR ANALOGOUS TRANSITIONS OF HALOGEN ATOMS. Djurovic S., Konjevic N., Z. Phys. D 11, 113.

4789. BROADENING AND SHIFT OF THE RESONANCE LINE OF THALLIUM DUE TO COLLISIONS WITH NEON AND ARGON ATOMS. Dygdala R. S., Bobkowski R., Lisicki E., J. Phys. B 22, 1563.

4790. IONIZATION ENERGY AND LEVEL SHIFTS OF MULTIPLY CHARGED IONS IN NON-IDEAL PLASMAS. Ebeling W., Kilimann K., Z. Naturforsch., Teil A 44, 519.

4791. SIMULATION OF STOCHASTIC MODEL PROCESSES IN THE THEORY OF STARK-BROADENING. Frerichs M. R., Z. Phys. D 11, 315. 
4792. FREQUENCY SHIFT IN THREE-PHOTON RESONANCE. Friedberg R., Hartmann S. R., Manassah J. T., Phys. Rev. A 39, 93.

4793. EXTENSION OF THE THEORY FOR THE INTENSITIES OF DIPOLE FORBIDDEN SPECTRAL LINES IN A PLASMA. Gaisinsky I. M., Oks E. A., J. Quant. Spectrosc. Radiat. Transfer 41, 235.

4794. STARK SHIFT OF THE He II $P_{\alpha}$ LINE IN A DENSE PLASMA. Gawron A., Hey J. D., Xu X. J., Kunze H. J., Phys. Rev. A 40, 7150.

4795. BROADENING AND SHIFT OF THE MAGNESIUM INTERCOMBINATION LINE AND FIRST TRIPLET LINE DUE TO THE PRESENCE OF THE NOBLE GASES. Gelbwachs J. A., Phys. Rev. A 39, 3343.

4796. ION DYNAMICS EFFECTS IN THE BALMER GAMMA LINE: COMPUTER SIMULATION Calculations. Gigosos M. A., Cardenoso V., J. Phys. B 22, 1743.

4797. PRECISE MEASUREMENT OF THE BALMER-ALPHA CORE. Gonzalez M. A., Gonzalez V. R., Mar S., J. Quant. Spectrosc. Radiat. Transfer 42, 247.

4798. EFFECTS OF STIMULATED RADIATIVE PROCESSES ON THE SPECTRAL STRUCTURE OF AMPLIFIED SPONTANEOUS EMISSION. Griem H. R., Phys. Rev. A 40, 3706.

4799. STARK BROADENING MEASUREMENT OF THE LINE 2058.13 nm OF NEUTRAL HELIUM IN A LINEAR DISCHARGE. Guimerans Y., Iglesias E. J., Mandelbaum D., Sanchez A., J. Quant. Spectrosc. Radiat. Transfer 42, 39.

4800. STARK SHIFT AND BROADENING OF HYDROGEN SPECTRAL LINES. Günter S., Contrib. Plasma Phys. 29, 479.

4801. SHIFT OF THE PEAKS OF THE $\mathrm{H}_{\beta}$ SPECTRAL LINE. Halenka J., Vujicic B. T., Djurovic S., J. Quant. Spectrosc. Radiat. Transfer 42, 571.

4802. DENSITY EXPANSIONS FOR THE AUTOCORRELATION FUNCTION OF SPECTRAL-LINE PROFILES. Hegerfeldt G. C., Schulze H., Phys. Rev. A 39, 3609.

4803. FURTHER PROPERTIES OF THE GENERALIZED FUNCTIONS OF HOLTSMARK, AND CHANDRASEKHAR AND VON NEUMANN. Hey J. D., J. Quant. Spectrosc. Radiat. Transfer $41 ; 167$. 
4804. THE CLASSICAL KRAMERS-GAUNT FACTOR IN STARK BROADENING CALCULATIONS. Hey J. D., Breger P., J. Phys. B 22, L79.

4805. RADIAL PROFILE OF THE SPECTRAL WIDTH OF THE Ar 7d[5/2]3-4p[3/2]2 LINE INSIDE THE CATHODE FALL REGION OF AR HOLLOW CATHODE DISCHARGES. Hirose C., Masaki T., Wada A., Adachi Y., Appl. Spectrosc. 43, 87.

4806. A MULTI-PARAMETER CHI-SQUARE FITTING PROCEDURE AND APPLICATIONS IN SPECTROSCOPY. Jess K., Helbig V., Greiner F., Kaspareit J., Rohde V., Weirauch T., J. Quant. Spectrosc. Radiat. Transfer 41, 69.

4807. A SIMPLE RELATIONSHIP BETWEEN THE VOIGT INTEGRAL AND THE PLASMA DISPERSION FUNCTION. ADDITIONAL METHODS TO ESTIMATE THE VOIGT INTEGRAL: Jimenez-Dominguez H., Flores-Llamas H., Cabral-Prieto A., Bravo-Ortega A., Nucl. Inst. Methods Phys. Res., Sect. A 278, 625.

4808. DECONVOLUTION VERSUS DERIVATIVE SPECTROSCOPY. Kalkandjiev T. K., Petrov V. P., Nickolov J. B., Appl. Spectrosc. 43, 44.

4809. QUANTUM-MECHANICAL AND CLASSICAL PATH LINE SHAPES FOR THE SODIUM D LINE BROADENED BY ARGON. Kearney W. R., Herman P. S., Sando K. M., Phys. Rev. A 40,7380 .

4810. INFLUENCE OF ION DYNAMICS ON THE WIDTH AND SHIFT OF ISOLATED He I LINES IN PLASMAS. Kobilarov R., Konjevic N., Popovic M. V., Phys. Rev. A 40, 3871 .

4811. ION LINES STARK SHIFTS IN SPECTRA OF HOT STARS. Krsljanin V., Publ. Obs. Astron. Belgrade No. 37, 1-114.

4812. ION PRESSURE SHIFTS OF Fe I LINES IN STELLAR ATMOSPHERES. Krsl janin V., "Solar and Stellar Granulation," 91 (Eds. R. J. Rutten and G. Severino, Kluwer Academic Publishers, Dordrecht, 1989).

4813. MODIFIED SEMIEMPIRICAL STARK WIDTHS AND SHIFTS OF Ar II LINES. Krsljanin V., Dimitrijevic M. S., Bull. Obs. Astron. Belgrade No. 140, 7.

4814. MODIFIED SEMIEMPIRICAL STARK SHIFTS OF Ar II LINES. Krsi janin V., Dimitrijevic M. S., Z. Phys. D 14, 273. 
4815. THE EFFECT OF RECOIL ON THE COLLISION BROADENING OF A SPECTRAL LINE. Lane A. M., J. Phys. B 22, 2817.

4816. STARK BROADENING IN KRYPTON AND XENON. Lesage A., Abadie D., Miller M. H. , Phys. Rev. A 40, 1367.

4817. ABSORPTION MEASUREMENTS OF RESONANCE BROADENING IN HELIUM. Lindsay A. C., Nicol J. L., Stacey D. N., Baird P. E. G., J. Phys. B 22, L303.

4818. EFFECT OF STRONG ELECTROMAGNETIC FIELDS ON ATOMIC SPECTRAL LINE SHAPES IN PLASMAS AND GASES. Lisitsa V. S., "Spectral Line Shapes," Vol. 5, 305-349 (Ossolineum, Wroclaw, Poland, 1989).

4819. STARK BROADENING OF THE HYDROGEN L LINES IN PLASMAS: RESONANCE BETWEEN THE QUASISTATIC AND HARMONIC ELECTRIC FIELDS. Lyublin B. V., Yakovlev D. G., Yasevich V. Yu., Sov. Phys.--Tech. Phys. 34, 167.

4820. BROADENING OF IRON RESONANCE LINES IN X-RAY BURST SPECTRA. Madej J., Astron. Astrophys. 209, 226.

4821. THE USE OF FOURIER DECONVOLUTION TO CORRECT FOR INSTRUMENT SLIT FUNCTION DIFFERENCES IN MEASURED SPECTRA. Mann C. K., Vickers T. J., Appl. Spectrosc. 43, 33 .

4822. WIDTH MEASUREMENTS OF THE PLASMA BROADENED He II BALMER-BETA LINE. Mijovic S., Pantelic D., Konjevic N., Popovic M., Fizika (Zagreb) 21, 319.

4823. NATURAL LINE SHAPE. Milonni P. W., Cook R. J., Ackerhalt J. R., Phys. Rev. A 40, 3764 .

4824. MEASUREMENTS OF GAIN AND LINE BROADENING IN LITHIUMLIKE ALUMINUM. Moreno J. C., Griem H. R., Goldsmith S., Knauer J., Phys. Rev. A 39, 6033.

4825. THE SURFACE GRAVITIES OF Ap STARS: SPECTROSCOPIC ESTIMATES FROM $\mathrm{H}_{\beta}$ PROFILES AND COMPARISON WITH PHOTOMETRY. North P., Kroll R., Astron. Astrophys., Suppl. Ser. 78, 325.

4826. SPECTROSCOPIC DETERMINATION OF ELECTRON DENSITY AND TEMPERATURE PROFILES IN AN INDUCTIVELY-COUPLED ARGON PLASMA. Nowak S., van der Mullen J. A. M., van der Sijde B., Schram D. C., J. Quant. Spectrosc. Radiat. Transfer 41,177 . 
4827. THEORY OF VELOCITY-DEPENDENT, COLLISION-BROADENED, DOPPLER-FREE LINE SHAPES. O'Callaghan M. J., Cooper J., Phys. Rev. A 39, 6206.

4828. SODIUM DOPPLER-FREE COLLISIONAL LINE SHAPES. O'Callaghan M. J., Gallagher A., Phys. Rev. A 39, 6190 .

4829. AN INSTRUMENTAL SYSTEM FOR SIMULTANEOUS MEASUREMENT OF SPATIALLY RESOLVED ELECTRON NUMBER DENSITIES IN PLASMAS. Olesik J. W., Den S.-J., Bradley K. R., Appl. Spectrosc. 43, 924.

4830. EXPERIMENTAL INVESTIGATION OF SATURATED LASER ABSORPTION IN THE STARK-BROADENED PROFILE OF THE BALMER LINE D. Osterhold M., Himmel G., Schlüter H., J. Quant. Spectrosc. Radiat. Transfer 41, 425.

4831. LINE BROADENING STUDIES IN LOW ENERGY PLASMA FOCUS. Rao P. M. R., Saraswathy P., Krishnamurty G., Rout R. K., Auluck S. K. H., Shyam A., Kulkarni I. V., Oza D. H., Pramana 32, 627.

4832. SHIFT AND BROADENING OF SPECTRAL LINES IN NON-IDEAL PLASMAS. Röpke G., Hitzschke L., "Spectral Line Shapes," Vol. 5, 49-72 (Ossolineum, Wroclaw, Poland, 1989).

4833. ELECTRIC MICROFIELD DISTRIBUTION AT AN ION IN THE CLASSICAL MULTiCOMPONENT PLASMA. Rosenfeld Y., Phys. Rev. A 40, 1137.

4834. REDISTRIBUTION OF RADIATION BY THE FLUCTUATING ION MICROFIELD. Ruffert M., Himmel G., Osterhold M., Schlüter H., J. Quant. Spectrosc. Radiat. Transfer $42,327$.

4835. STARK LINE-BROADENING PARAMETERS OF NEUTRAL LEAD AND SINGLY IONIZED COPPER. Sarandaev E. V., Salakhov M. Kh., Opt. Spectrosc. (USSR) 66, 268.

4836. STARK BROADENING OF He II LINES AND NEW RESULTS IN ASTROPHYSICAL SPECTROSCOPY. Schöning T., Butler K., Astron. Astrophys. 219, 326.

4837. STARK BROADENING OF He II LINES. Schöning T., Butler K., Astron. Astrophys., Suppl. Ser. 78, 51; 79, 153 (1989).

4838. ATOMIC DATA FOR OPACITY CALCULATIONS: XII. LINE-PROFILE PARAMETERS FOR NEUTRAL ATOMS OF He, C, N AND O. Seaton M. J., J. Phys. B 22, 3603. 
4839. POLARIZATION-MONITORED COLLISIONAL REDISTRIBUTION EXPERIMENT IN: $\mathrm{Hg}\left({ }^{3} \mathrm{P}_{1}-{ }^{1} \mathrm{~S}_{0}\right)-\mathrm{Kr}$. Segal D., Burnett K., J. Phys. B 22, 247.

4840. DETERMINATION OF THE RADIATIVE CROSS SECTION FOR THE ${ }^{2} \mathrm{P}_{1 / 2}-{ }^{2} \mathrm{P}_{3 / 2}$ TRANSITION OF ATOMIC CHLORINE. Sotnichenko S. A., Bokun V. C., Nadkhin A. I., Opt. Spectrosc. (USSR) 67, 597.

4841. UNIFIED AND IMPACT TREATMENT OF PARTIALLY OVERLAPPING SPECTRAL LINES. Stehlé C., Voslamber D., Feautrier N., J. Phys. B 22, 3657.

4842. COLLISION-INDUCED SATELLITE FOR THE ASYMPTOTICALLY FORBIDDEN TRANSITION $\left(4^{2} S-5^{2} S\right)$ OF POTASSIUM PERTURBED BY NEON. Tchang-Brillet W. -Ü. L., Spielfiedel A., Feautrier N., Haner D., J. Phys. B 22, 3915.

4843. H $\beta$ LINE PROFILE MEASUREMENTS IN OPTICAL DISCHARGES. Uhlenbusch J., Viöl W. , Contrib. Plasma Phys. 29, 459.

4844. IMPACT BROADENING AND SHIFT OF THALLIUM TWO-PHOTON TRANSITION: $6 \mathrm{P}_{1 / 2}-9 \mathrm{P}_{1 / 2,3 / 2}$ PERTURBED BY ARGON AND HELIUM. Ullah K. N., Nuovo Cimento D 11,1349 .

4845. STARK BROADENING AND SHIFT OF $\mathrm{Kr} I$ and $\mathrm{Kr}$ II LINES IN DENSE PLASMA. Uzelac N. I., Konjevic N., J. Phys. B 22, 2517.

4846. FOURIER DECONVOLUTION OF OVERLAPPING LINE PAIRS IN INDUCTIVELY COUPLED PLASMA-ATOMIC EMISSION SPECTROMETRY. van Veen E. H., Goudzwaard M. P., de Loos-Vollefregt M. T. C., de Galan L., Appl. Spectrosc. 43, 96.

4847. INVESTIGATION OF THE COLLISIONAL LIMB EFFECT AND SHAPE OF SOLAR SPECTRAL LINES AT THE ASTRONOMICAL OBSERVATORY IN BELGRADE. Vince I., Bull. Obs. Astron. Belgrade No. 140, 117 .

4848. PRESSURE BROADENING AND SOLAR SPECTRAL LINE BISECTORS. Vince I., Dimitrijevic M. S., "Solar and Stellar Granulation," 93-97 (Eds. R. J. Rutten and G. Severino, Kluwer Academic Publishers, Dordrecht, 1989).

4849. THE STARK BROADENING OF THE He I $667.8 \mathrm{~nm}$ LINE. Vujicic B. T., Djurovic S., Halenka J., Z. Phys. D 11, 119.

4850. LINE-BROADENING MEASUREMENT OF C V n=2, $\mathrm{n}=0$ TRANSITIONS IN A LASER-PRODUCED PLASMA. Wang J. S., Griem H. R., Iglesias E. J., Phys. Rev. A 40, 4115 . 
4851. STARK BROADENING OF THE $\mathrm{H}_{\alpha}$ and $\mathrm{H}_{\beta}$ LINES BY QUASISTATIC AND RAPIDLY OSCILLATING ELECTRIC FIELDS. Yakovlev D. G., Yasevich V. Yu., Ljublin B. V., J. Phys. B 22, 3851 .

4852. COLLISION-INDUCED SATELLITE OF THE FORBIDDEN LINE Hg $6{ }^{3} \mathrm{P}_{2}-6{ }^{1} \mathrm{~S}_{0}$ AND DECAY OF THE METASTABLE STATE Hg $\left(6{ }^{3} \mathrm{P}_{2}\right)$ IN INERT GASES. Zagrebin A. L., Lednev M. G., Sov. Tech. Phys. Lett. 15, 956.

4853. COLLISIONAL SATELLITES OF THE ${ }^{3} \mathrm{P}_{2}-{ }^{1} \mathrm{~S}_{0}$ FORBIDDEN LINES OF Ar, Kr, AND Xe ATOMS IN HELIUM AND NEON. Zagrebin A. L., Pavlovskaya N. A., Opt. Spectrosc. (USSR) 66, 582 .

4854. SHORT-WAVELENGTH SATELLITES OF Ne $2 p^{5} 5 s-2 p^{5} 3 p$ SPECTRAL LINES IN HELIUM. Zagrebin A. L., Sebyakin Yu. N., Opt. Spectrosc. (USSR) 66, 739.

4855. THE CONTRIBUTION OF PLASMA TURBULENCE FIELDS TO THE STARK BROADENING FUNCTIONS. Zhang Z., Lin J., Wang Z., Acta Astrophys. Sinica 9, 60.

4856. NON-BINARY LINEAR STARK BROADENING IN AN IDEAL PLASMA. Zhidkov A. G., Terskikh A. O., Kratk. Soobshch. Fiz. No 9, 27.(Russ.)

1990

4857. TIME-RESOLVED EMISSION SPECTROSCOPY IN LASER-GENERATED NITROGEN PLASMAS. Alam R. C., Fletcher S. J., Wasserman K. R., Hüwel L., Phys. Rev. A 42, 383.

4858. GREEN FUNCTION APPROACH TO THE THEORY OF SPECTRAL LINE BROADENING IN A PLASMA VIA THE TIME-DEPENDENT MICROFIELD. Alexiou S., Phys. Lett. A 143, 134.

4859. EMISSION SPECTRA OF HIGH RYDBERG STATES IN A PLASMA: STARK-BROADENED NEUTRAL OXYGEN IN THE $7.5 \mu \mathrm{m}$ REGION. Alexiou S., Baird J. C., Phys. Rev. A 42,7413 .

4860. LINE FORMATION IN WHITE DWARF ATMOSPHERES. Allard F., Wehrse R., J. Quant. Spectrosc. Radiat. Transfer 44, 209.

4861. FAR WING OF THE LYMAN- $\alpha$ LINE. Allard N. F., Kielkopf J. F., Ann. Phys. (Paris) Colloq. No $3, \mathbf{1 5}, 55$. (Fr.) 
4862. THE LYMAN $\alpha$ LINE WING. Allard N. F., Kielkopf J., AIP Conference Proceedings 216, "Spectral Line Shapes," Vol. 6, 604 (Eds. L. Frommhold \& J. W. Keto, AIP, New York, 1990) .

4863. NONLINEAR INTERFERENCE EFFECTS IN STARK BROADENING OF ION LINES IN A DENSE PLASMA. Anufrienko A. V., Godunov A. L., Demura A. V., Zemtsov Yu. K., Lisitsa V. S., Starostin A. N., Taran M. D., Shchipakov V. A., Sov. Phys.--JETP 71, 728.

4864. MEASUREMENT OF THE SHIFT OF THE $703 \mathrm{~nm}$ LINE OF ARGON: DETERMINATION OF THE ELECTRON DENSITY IN AN ARGON PLASMA. Badie J. M., Billou E., Vallbona G., Rev. Phys. App1. 25, 527.(Fr.)

4865. HYDROGENIC SPECTROSCOPY FOR VARIOUS UNUSUAL PLASMAS. Bakshi P., Kalman G., J. Quant. Spectrosc. Radiat. Transfer 44, 93.

4866. SPECTRAL DIAGNOSTIC OF A RESONANTLY LASER CREATED PLASMA. Bardet J. P., Bobin J. L., Dimarcq C., Giry L., Larour J. B., Valognes J. C., Zaibi M. A., Laser Part. Beams 8, 307.

4867. POLARIZATION AND ION SHIFTS OF IONIZED-HELIUM LINES IN DENSE PLASMAS. Benredjem D. E., Nguyen Hoe, Coulaud G., J. Quant. Spectrosc. Radiat. Transfer 43, 415 .

4868. ON LONGITUDINAL OSCILLATIONS IN STRONGLY COUPLED PLASMAS. Berkovsky M. A., Kurilenkov Yu. K., J. Quant. Spectrosc. Radiat. Transfer 44, 25.

4869. FOREIGN-GAS COLLISIONAL BROADENING OF RYDBERG STATES IN CALCIUM. Bhatia K. S., Makdisi Y., Zaidi A. A., Abdulla A. G. H., Hussein R. M., J. Phys. B 23,801 .

4870. LOW-PRESSURE BROADENING AND SHIFT OF $3 p^{5} 4 s-3 p^{5} n p(n=4,5,6)$ ARGON SPECTRAL LINES PERTURBED BY He,Ne,Ar. Bielski A., Pospieszny J., Szudy J., Trawinski R. S., Wolnikowski J., J. Phys. B. 23, 2003.

4871. ELECTRON COLLISION SHIFT OF THE LYMAN- $\alpha$ LINE OF IONIZED HELIUM. Blaha M., Davis J., Phys. Rev. A 41, 6928.

4872. MODEL FOR STARK-BROADENING IN MULTI-ELECTRON ATOMS. Calisti A., Khelfaoui F., Stamm R., Talin B., Ann. Phys. (Paris) Colloq. No 3, 15, 67.(Fr.) 
4873. MODEL FOR THE LINE SHAPES OF COMPLEX IONS IN HOT AND DENSE PLASMAS. Calisti A., Khelfaoui F., Stamm R., Talin B., Phys. Rev. A 42, 5433.

4874. ON THE SCATTERING OF A LIGHT PULSE ON A SINGLE ATOM PERTURBED BY COLLISIONS WITH INERT GAS ATOMS. III. THE $\mathrm{S}_{1 / 2}-\mathrm{P}_{1 / 2}$ TRANSITION. Czub J., Fiutak J., Miklaszewski W., Z. Phys. D 17, 163.

4875. THE DISAPPEARANCE OF UPPER MEMBERS OF SPECTRAL SERIES IN DENSE PLASMAS. D'Yachkov L. G., Kobzev G. A., Pankratov P. M., J. Quant. Spectrosc. Radiat. Transfer 44, 123

4876. LINE BROADENING BY LOW-FREQUENCY TURBULENCE. Deutsch C., Vanderhaegen D., J. Quant. Spectrosc. Radiat. Transfer 44, 109.

4877. THEORETICAL CALCULATION OF ELECTRON IMPACT WIDTHS AND SHIFTS OF Xe II LINES. Di Rocco H. O., Nuovo Cimento Soc. Ital. Fis., D 12, 1485.

4878. A GENERAL TREND FOR THE STARK WIDTHS OF SINGLE IONIZED NOBLE GASES. Di Rocco H. 0., J. Appl. Phys. 68, 3732.

4879. CHEMICAL EXCHANGE EFFECTS IN SPECTRAL LINE SHAPES. Diaz M. A., Veguillas J., Can. J. Phys. 68, 563.

4880. ACCURACY OF LINE BROADENING DATA. Dimitrijevic M. S., "Lecture Notes in Physics - Accuracy of Element Abundances from Stellar Atmospheres," No. $356,31-44$.

4881. STARK BROADENING OF He I LINES. Dimitrijevic M. S., Sahal-Bréchot S., Astron. Astrophys., Suppl. Ser. 82, 519

4882. TABLES FOR Na I LINES STARK BROADENING PARAMETERS. Dimitrijevic M. S., Sahal-Bréchot S., Bull. Obs. Astron. Belgrade No. 142, 59.

4883. STARK BROADENING OF K I LINES. Dimitrijevic M. S., Sahal-Bréchot S., Bull. Obs. Astron. Belgrade No. 142, 29.

4884. PLASMA SCREENING EFFECTS ON STARK BROADENING OF ION LINES AT THE ADIABATIC LIMIT. Dimitrijevic M. S., Atanackovic-Vukmanovic 0., Ann. Phys. (Paris) Colloq. No 3, 15, 75 . 
4885. LINE PROFILE PARAMETERS FOR Li-LIKE IONS. Dimitrijevic M. S., Sahal-Bréchot S., Ann. Phys. (Paris) Colloq. No 3, 15, 77.

4886. REGULARITIES AND SIMILARITIES IN THE WIDTHS OF SPECTRAL LINES PERTURBED BY NEUTRAL ATOMS. Dimitrijevic M. S., Peach G., Astron. Astrophys. 236, 261.

4887. STARK BROADENING OF Na I LINES WITH THE PRINCIPAL QUANTUM NUMBER OF THE UPPER STATE BETWEEN 6 AND 10. Dimitrijevic M. S., Sahal-Bréchot S., J. Quant. Spectrosc. Radiat. Transfer 44, 421.

4888. LINE SHAPES INVESTIGATIONS IN YUGOSLAVIA (1962-1985). Dimitrijevic M. S., Pub1. Obs. Astron. Belgrade No. 39, 1-215.

4889. STARK-BROADENING REGULARITIES OF np-nd TRANSITION ARRAYS OF NITROGEN, OXYGEN, NEON, AND SILICON ION SPECTRAL LINES. Djenize S., Labat J., Platisa M., Sreckovic A., Puric J., Astron. Astrophys. 227, 291.

4890. STARK BROADENING AND SHIFT OF SINGLY AND DOUBLY IONIZED SULFUR SPECTRAL LINES. Djenize S., Sreckovic A., Platisa M., Konjevic R., Labat J., Puric J., Phys. Rev. A 42, 2379.

4891. STARK BROADENING AND SHIFT OF NEUTRAL AND SINGLY-IONIZED MERCURY LINES. Djenize S., Sreckovic A., Platisa M., Labat J., Konjevic R., Puric J., J. Quant. Spectrosc. Radiat. Transfer 44, 405.

4892. STARK WIDTH AND SHIFT OF SINGLY-IONIZED TIN SPECTRAL LINES. Djenize S., Sreckovic A., Labat J., Z. Phys. D 17, 85.

4893. STARK BROADENING OF HALOGEN ATOM LINES FROM ( ${ }^{1}$ D) np LEVELS. Djurovic S., Konjevic N., Dimitrijevic M. S., Z. Phys. D 16, 255.

4894. MODELS FOR SPECTRAL LINE SHAPES FROM IONS IN STRONGLY COUPLED PLASMAS. Dufty J. W., Boercker D. B., Iglesias C. A., J. Quant. Spectrosc. Radiat. Transfer 44, 115.

4895. HIGH RESOLUTION SPECTROSCOPY OF THE HYDROGEN ATOM. II. STUDY OF LINE PROFIlES. Garreau J. C., Allegrini M., Julien L., Biraben F., J. Phys. (Paris) 51, 2275. 
4896. LARGE MULTIPLE COLLECTIVE LINE SHIFTS OBSERVED IN THREE-PHOTON EXCITATIONS OF Xe. Garrett W. R., Hart R. C., Wray J. E., Datskou I., Payne M. G., Phys. Rev. Lett. 64, 1717.

4897. SPECTRAL LINE BROADENING OF MULTIPLY CHARGED-HELIUM-LIKE IONS IN A DENSE HIGH-TEMPERATURE PLASMA. Gavrilenko V. P., Ispolatov Ya. O., Opt. Spectrosc. (USSR) 68, 583.

4898. ANALYTIC FIT OF MONTE-CARLO DISTRIBUTIONS OF THE ELECTRIC MICROFIELD IN A PLASMA. Gilles D., Ann. Phys. (Paris) Colloq. No 3, 15, 85.

4899. PLASMA POLARIZATION SHIFT OF THE LYMAN- $\alpha$ LINE IN C VI, N VII, AND 0 VIII. Goldsmith S., J. Quant. Spectrosc. Radiat. Transfer 44, 153.

4900. STARK-PROFILE CALCULATIONS FOR RESONANCE LINES OF HELIUMLIKE ARGON IN DENSE PLASMAS. Griem H. R., Blaha M., Kepple P. C., Phys. Rev. A 41, 5600.

4901. SPECTRAL LINE BROADENING IN X-RAY LASER RESEARCH. Griem H. R., Moreno J. C., Inst. Phys. Conf. Ser. No. 116, 301.

4902. ION BROADENING PARAMETERS FOR SEVERAL ARGON AND CARBON LINES. Hahn T. D., Woltz L. A., Phys. Rev. A 42, 1450.

4903. ASYMMETRY OF HYDROGEN LINES IN PLASMAS UTILIZING A STATISTICAL DESCRIPTION OF ION-QUADRUPOLE INTERACTION IN MOZER-BARANGER LIMIT. Halenka J., Z. Phys. D 16, 1.

4904. CORRELATIONS AND MICROFIELDS IN DENSE PLASMAS. Held B., J. Quant. Spectrosc. Radiat. Transfer 44, 11.

4905. STARK BROADENING OF Ar IV LINES IN A DENSE PLASMA. Hey J. D., Gawron A., Xu X. J., Breger P., Kunze H.-J., J. Phys. B 23, 241.

4906. LASER-DRIVEN IMPLOSIONS OF Ne/Ar AND Ar/Kr GAS-FILLED MICROBALLOONS: SPECTROSCOPIC ANALYSIS. Hooper C. F. Jr., Woltz L. A., Mancini R. C., Delamater N. D., Richardson M. C., Kauffman R. L., J. Quant. Spectrosc. Radiat. Transfer 44, 79.

4907. MEASUREMENTS OF STARK BROADENING OF B V AND N V n $=6$ to 7 and 5 to 6 TRANSITIONS IN A LASER-PRODUCED PLASMA. Huang Y. W., Böttcher F., Wang J. S., Griem H. R., Phys. Rev. A 42, 2322. 
4908. MEASUREMENT AND INTERPRETATION OF SPONTANEOUS LINE EMISSION FROM A COMMON UPPER LEVEL IN LASER-PRODUCED CARBON PLASMAS. Huang Y. W., Wang J.-S., Moreno J. C., Griem H. R., Phys. Rev. Lett. 65, 1757.

4909. COLLISION BROADENING AND SHIFT OF CESIUM $\mathrm{D}_{2}$ RESONANCE LINE PERTURBED BY EVERY RARE GAS. Inoue Y., Uchida K., Hori H., Sakurai T., J. Phys. Soc. Jpn 59, 516.

4910. EXPERIMENTAL STUDY OF THE ROLE OF PLASMA POLARIZATION ON LINE SHAPE IN DENSE LABORATORY PLASMAS. Jamelet G., Jaegle P., Lemaire P., Carillon A., J. Quant. Spectrosc. Radiat. Transfer 44, 71.

4911. MICROFIELD EFFECTS: STRONGLY COUPLED PLASMAS. Kalman G., Bakshi P., J. Quant. Spectrosc. Radiat. Transfer 44, 1.

4912. LINE BROADENING OF Ne-like XENON AS A DIAGNOSTIC FOR HIGH-DENSITY IMPLOSION EXPERIMENTS. Keane C. J., Lee R. W., Hammel B. A., Osterheld A. L., Suter L. J., Calisti A., Khelfaoui F., Stamm R., Talin B., Rev. Sci. Instrum. 61,2780 .

4913. AN OVERVIEW OF THE ION DYNAMIC EFFECT IN LINE BROADENING, AND A GENERALIZATION OF THE UNIFIED THEORY. Kelleher D. E., Oza D. H., Cooper J., Greene R. L., J. Quant. Spectrosc. Radiat. Transfer 44, 101.

4914. ENERGY GAP AND LINE SHIFTS FOR H-LIKE IONS IN DENSE PLASMAS. Kilimann K., Ebeling W., Z. Naturforsch., Teil A 45, 613.

4915. PLASMA SHIFT AND BROADENING OF ANALOGOUS TRANSITIONS OF S II, CI III, Ar IV, Cl II, AND Ar III. Kobilarov R., Konjevic N., Phys. Rev. A 41, 6023.

4916. A REVIEW OF THE STARK WIDTHS AND SHIFTS OF SPECTRAL LINES FROM NON-HYDROGENIC ATOMS AND IONS IN WEAKLY-COUPLED PLASMAS AND EXPERIMENTAL RESULTS FOR Xe I AND Xe II LINES. Konjevic N., Uzelac N. I., J. Quant. Spectrosc. Radiat. Transfer 44, 61.

4917. EXPERIMENTAL STARK WIDTHS AND SHIFTS FOR SPECTRAL LINES OF NEUTRAL AND IONIZED ATOMS (A CRITICAL REVIEW OF SELECTED DATA FOR THE PERIOD 1983 THROUGH 1988). Konjevic N., Wiese W. L., J. Phys. Chem. Ref. Data 19, 1307. 
4918. COLLISIONAL BROADENING OF Ba I LINE (553.5 nm) by He or Ar. Kuchta E., Alvarez II R. J., Li Y. H., Krueger D. A., She C. Y., Appl. Phys. B 50, 129.

4919. STARK BROADENING OF SINGLY AND DOUBLY IONIZED IODINE SPECTRAL LINES. Labat 0., Denize S., Labat J., Puric J., Sreckovic A., Phys. Lett. A 143,455 .

4920. TEMPERATURE DEPENDENCE OF STARK PARAMETERS FOR Fe I LINES. Lesage A., Lebrun J. L., Richou J., Astrophys. J. 360, 737.

4921. SIGNIFICANCE OF THE PRESSURE SHIFT OF BALMER LINES IN WHITE DWARFS WITH EXTREMELY HIGH GRAVITY. Madej J., Grabowski B., Astron. Astrophys. 229, 467.

4922. ANALYSIS OF ABSORPTION FEATURES IN DENSE ARGON PLASMAS. Mancini R. C., Hooper C. F. Jr., Rev. Sci. Instrum. 61, 2738.

4923. OBSERVATION OF LINE SHIFTS AND LINE PROFILES IN AN INDUCTIVELY COUPLED ARGON PLASMA. Manning T. J., Winefordner J. D., Palmer B. A., Hof D. E., Spectrochim. Acta, Part B 45, 1031.

4924. THE TRANSFER OF POLARIZED LIGHT IN STARK BROADENED HYDROGEN LINES IN THE PRESENCE OF A MAGNETIC FIELD. Mathys G., J. Quant. Spectrosc. Radiat. Transfer 44, 143 .

4925. USE OF A PRIORII INFORMATION OF SPECTRAL-LINE SHAPE IN THE SOLUTION OF A REDUCTION PROBLEM. Mishin I. V., Opt. Spectrosc. (USSR)69, 133.

4926. Stark Broadening of Several Si II LINES. Pérez C., De La Rosa M. I., De Frutos A. M., Gonzalez V. R., Mar S., Ann. Phys. (Paris) Colloq. No 3, 15,115 .

4927. ION CORRELATIONS AND ION MICROFIELDS AT IMPURITIES IN DENSE PLASMAS. Perrot F., Dharma-wardana M. W. C., Phys. Rev. A 41, 3281.

4928. ENERGETIC ANALYSIS OF $\mathrm{H}_{\alpha}$ PROFILES IN THE CATHODE REGION OF A DISCHARGE. Plain A., Barbeau C., Jolly J., Ann. Phys. (Paris) Colloq. No 3, $15,117 .($ Fr. $)$ 
4929. ATOMIC DATA FOR OPACITY CALCULATIONS: XIII. LINE PROFILES FOR TRANSITIONS IN HYDROGENIC IONS. Seaton M. J., J. Phys. B 23, 3255.

4930. CONTOUR OF Yb 398.8-nm LINE ABSORPTION UNDER RESONANCE BROADENING AND POTENTIALS OF Yb-Yb INTERACTIONS. Shabanova L. N., Opt. Spectrosc. (USSR) $69,443$.

4931. A UNIFIED PRESENTATION OF THE VOIGT FUNCTIONS. Siddiqui A., Astrophys. Space Sci. 167, 263.

4932. COLLISIONAL BROADENING AND SHIFT OF THE $4 \mathrm{p}^{3} \mathrm{P}_{\mathrm{J}}-5 \mathrm{~s}^{3} \mathrm{~s}_{1}$ FINE STRUCTURE LINES OF CALCIUM PERTURBED BY HYDROGEN ATOMS. Spielfiede1 A., Feautrier N., Chambaud G., Levy B., Ann. Phys. (Paris) Colloq. No 3, 15, 119.

4933. STARK BROADENING REGULARITIES WITHIN SUCCESSIVE IONIZATION STAGES OF PHOSPHORUS AND SULFUR. Sreckovic A., Djenize S., Labat J., Platisa M., Puric J., Fizika (Zagreb) 22, 583.

4934. SIMULATION MICROFIELD METHOD FOR PLASMA SPECTROSCOPY. Stamm R., Calisti A., Kaftand jian P. V., Talin B., J. Quant. Spectrosc. Radiat. Transfer $44,19$.

4935. WHAT IS MEANT BY LOW OR HIGH DENSITIES IN THE STARK BROADENING OF HYDROGENIC ION LINES?. Stehlé C., J. Quant. Spectrosc. Radiat. Transfer 44, 135 .

4936. MARKOVIAN AND NON-MARKOVIAN TREATMENTS OF PARTIALLY OVERLAPPING LINES. Stéhle C., Voslamber D., Feautrier N., Ann. Phys. (Paris) Colloq. No 3, $15,121 .(\mathrm{Fr}$.

4937. MEASUREMENTS OF SELF BROADENING OF THE TRIPLET LINE $\dot{\lambda}=706.5 \mathrm{~nm}$ IN HELIUM. Su J. F., Nicol J. L., J. Phys. B 23, 2215.

4938. BEHAVIOR OF ALLOWED $\left(4^{3} \mathrm{D}-2{ }^{3} \mathrm{P}\right)$ AND FORBIDDEN $\left(4^{3} \mathrm{~F}-2{ }^{3} \mathrm{P}\right)$ COMPONENTS OF THE He $4472 \AA$ LINE IN HIGH ELECTRON DENSITY He Z-PINCH PLASMAS. Suemitsu H., Ikawi K., Takemoto Y., Yoshida E., J. Phys. B 23, 1129.

4939. THEORETICAL CALCULATION OF IMPACT BROADENING RATES OF Rb nS RYDBERG LEVELS BY NOBLE GASES. Sun J.-Q., West P. J., J. Phys. B23, 4119. 
4940. INTERACTION POTENTIAL OF THE H-He SYSTEM AND THE HYPERFINE FREQUENCY SHIFT OF H IN He BUFFER GAS. Tang K. T., Yang X. D., Phys. Rev. A 42, 311.

4941. $\mathrm{H}_{\beta}$-LINE PROFILE MEASUREMENTS IN OPTICAL DISCHARGES. Uhlenbusch J., Viöl W., J. Quant. Spectrosc. Radiat. Transfer 44, 47.

4942. SHIFTS OF THE SPECTRAL LINES OF $\mathrm{He}^{+}$PRODUCED BY ELECTRON COLLISIONS. Unnikrishnan K., Callaway J., Oza D. H., Phys. Rev. A 42, 6602.

4943. SPECTRAL DIAGNOSTIC OF A RESONANTLY LASER CREATED NON-DEBYE PLASMA. Valognes J. C., Bardet J. P., Dimarcq C., Giry L., J. Phys. (Paris) 51, 2033.

4944. XENON-INDUCED BLUE SHIFT OF THULIUM ABSORPTION LINES. Vedenin V. D., Opt. Spectrosc. (USSR) 69, 726.

4945. COLLISIONAL BROADENING AND SHIFT OF THE 539.4 nm ARGON LINE. Wolnikowski J., Phys. Scr. 42, 220.

4946. QUASISTATIC WINGS OF THE RESONANCE LINES OF Ne, Ar, $\mathrm{Kr}$, and Xe ATOMS IN HELIUM. Zagrebin A. L., Pavlovskaya N. A., Opt. Spectrosc. (USSR) 68, 19.

4947. QUASISTATIC SATELlites OF RESONANCE LINES OF ATOMIC Ar, Kr, AND Xe IN NEON. Zagrebin A. L., Pavlovskaya N. A., Opt. Spectrosc. (USSR) 68, 289.

$$
1991
$$

4948. STARK-BROADENING OF THE HELIUM LINES 447 AND $492 \mathrm{~nm}$ AT LOW ELECTRON DENSITIES. Adler H. G., Piel A., J. Quant. Spectrosc. Radiat. Transfer 45, 11 .

4949. TIME-DEPENDENT STATISTICAL PROPERTIES OF THE ELECTRIC MICROFIELD SEEN BY A NEUTRAL RADIATOR. Alastuey A., Lebowitz J. L., Levesque D., Phys. Rev. A 43, 2673 .

4950. TEMPERATURE AND DENSITY DEPENDENCE OF THE LYMAN $\alpha$ LINE WING IN HYDROGEN-RICH WHITE DWARF ATMOSPHERES. Allard N. F.; Kielkopf J., Astron. Astrophys. 242, 133.

4951. THE LYMAN ALPHA LINE WING IN HYDROGEN-RICH WHITE DWARF ATMOSPHERES. Allard N. F., Kielkopf J., "White Dwarfs," 353-360 (Eds. G. Vauclair \& E. Sion, Kluwer Academic, Dordrecht, Holland, 1991). 
4952. COLLISIONAL BROADENING AND SHIFT OF THE ALKALI RESONANCE LINES. Andretta V., Gomez M. T., Severino G., Solar Phys. 131, 1.

4953. AN INVESTIGATION OF BRUECKNER'S THEORY OF LINE BROADENING WITH APPLiCATION TO THE SODIUM D LiNES. Anstee S. D., O'Mara B. J., Mon. Not. R. Astron. Soc. 253, 549 .

4954. OVERLAPPED STARK PROFILES OF COINCIDENT X-RAY LINES AS POSSIBLE DIAGNOSTICS OF CORE-SHELL MIXING IN SPHERICAL PLASMA IMPLOSIONS. Apruzese J. P., Kepple P. C., Phys. Rev. A 43, 6964.

4955. SPECTROSCOPIC MEASUREMENTS OF ELECTRON DENSITY OF CAPILLARY PLASMA BASED ON STARK BROADENING OF HYDROGEN LINES. Ashkenazy J., Kipper R., Caner M., Phys. Rev. A 43, 5568 .

4956. EXPERIMENTAL DETERMINATION OF THE ION BROADENING PARAMETER OF THE $703 \mathrm{~nm}$ LINE OF NEUTRAL ARGON. Badie J. M., Bacri J., J. Phys. D24, 809.(Fr.)

4957. DIAGNOSTICS OF THE PLASMA IN A HIGH POWER INDUCTION PLASMATRON BY THE INTENSITY AND BROADENING OF SPECTRAL LINES. Baronets P. N., Bykova N. G., J. App1. Spectrosc. (USSR) 54, 399.

4958. EXPERIMENTAL STARK WIDTHS OF XENON II SPECTRAL LINES. Bertuccelli D., Bertuccelli G., Di Rocco H. O., Phys. Scr. 43, 469.

4959. OPTICAL TRANSITION PROBABILITIES FOR LINES OBTAINED FROM PULSED SOURCES. Bertuccelli D., Bertuccelli G., Di Rocco H. O., Rev. Sci. Instrum.62, 966.

4960. STARK WIDTHS OF SINGLE IONIZED KRYPTON AND BROADENINंG REGULARITIES. Bertuccelli G., Di Rocco H. O., Phys. Scr. 44, 138.

4961. PRESSURE EFFECTS ON $2 p^{5} 3 p-2 p^{5} 5 d$ AND $2 p^{5} 3 p-2 p^{5} 6 d$ TRANSITIONS IN NEON. Bielski A., Brym S., Szudy J., Trawinski R. S., Wolnikowski J., J. Phys. B 24, 4909 .

4962. PRESSURE EFFECTS ON THE 506 nm ARGON LINE. Bielski A., Trawinski R. S., Wolnikowski J., Szudy J., Phys. Scr. 44, 141.

4963. COMPENSATION OF THE SECOND-ORDER DOPPLER EFFECT IN TWO-PHOTON SPECTROSCOPY OF ATOMIC HYDROGEN. Biraben F., Julien L., Plon J., Nez F., Europhys. Lett. 15, 831. 
4964. COLLISIONAL BROADENING OF RYDBERG STATES BY ALKALI-METAL PERTURBERS. Borodin V. M., Fabrikant I. I., Kazansky A. K., Phys. Rev. A 44, 5725.

4965. RESONANCE FLUORESCENCE IN RADIATIVE COLLISIONS: THEORETICAL STUDY OF THE SPEGTRAL LINE SHAPES. Buffa R., Matera M., Phys. Rev. A 44, 5833.

4966. ON THE MECHANISM OF DOPPLER BROADENING OF H AFTER DISSOCIATIVE EXCITATION IN HYDROGEN GLOW DISCHARGES. Bzenic S. A., Radovanov S. B., Vrhovac S. B., Velikic Z. B., Jelenkovic B. M., Chem. Phys. Lett. 184, 108.

4967. SHIFT AND WIDTH OF THE BALMER- $\alpha$ AND LYMAN- $\beta$ LINES OF NEUTRAL HYDROGEN DUE TO ELECTRON COLLISIONS. Callaway J., Unnikrishnan K., Phys. Rev. A 44, 3001 .

4968. COLLISIONAL-REDISTRIBUTION MEASUREMENTS INCLUDING THE EFFECT OF VELOCITY. Capozzi F., Belsley M., Ewart P., Phys. Rev. A 44, 6136.

4969. EXPERIMENTAL DETERMINATION AND CALCULATION OF THE COLLISION RELAXATION RATES IN THE $5{ }^{2} \mathrm{P}_{1 / 2}$ AND $5{ }^{2} \mathrm{P}_{3 / 2}$ LEVELS OF ATOMIC IODINE. Cerny D., Bacis R., Bussery B., Nota M., Verges J., J. Chem. Phys. 95, 5790.

4970. RADIATION TRAPPING IN THE FAR WINGS OF THE FOREIGN-GAS BROADENED POTASSIUM RESONANCE LINES. Colbert T., Huennekens J., Phys. Rev. A 44 , 4753.

4971. STARK BROADENING OF Li I LINES. Dimitrijevic M. S., Sahal-Bréchot S., J. Quant. Spectrosc. Radiat. Transfer 46, 41.

4972. LINE SHAPES INVESTIGATIONS IN YUGOSLAVIA II (1985-1989). Dimitrijevic M. S., Publ. Obs. Astron. Belgrade No. 41, 1-129.

4973. BROADENING OF Li I LINES BY COLLISIONS WITH CHARGED PARTICLES. Dimitrijevic M. S., Sahal-Bréchot S., Bull. Obs. Astron. Belgrade No. $143,29(1991)$.

4974. SEMICLASSICAL CALCULATIONS OF STARK BROADENING PARAMETERS. Dimitrijevic M. S., Sahal-Bréchot S., J. Phys. IV, Colloq. C1 1, G1-111.

4975. STARK BROADENING OF SPECTRAL LINES OF MULTICHARGED IONS OF ASTROPHYSICAL INTEREST. I. C IV LINES. Dimitrijevic M. S., Sahal-Bréchot S., Bommier V., Astron. Astrophys., Suppl. Ser. 89, 581. 
4976. STARK BROADENING OF SPECTRAL LINES OF MULTICHARGED IONS OF ASTROPHYSICAL INTEREST. II. Si IV LINES. Dimitrijevic M. S., Sahal-Bréchot S., Bommier V., Astron. Astrophys., Suppl. Ser 89, 591.

4977. STARK BROADENING PARAMETER TABLES FOR SPECTRAL LINES OF MULTICHARGED IONS OF ASTROPHYSICAL INTEREST. I: C IV LINES. Dimitrijevic M. S., Sahal-Bréchot S., Bommier V., Bull. Obs. Astron. Belgrade No. 144, 65.

4978. STARK BROADENING PARAMETER TABLES FOR SPECTRAL LINES OF MULTICHARGED IONS OF ASTROPHYSICAL INTEREST. II. Si IV LINES. Dimitrijevic M. S., Sahal-Bréchot S., Bommier V., Bull. Obs. Astron. Belgrade No 144, 81.

4979. STARK BROADENING AND SHIFT OF SINGLY AND DOUBLY IONIZED FLUORINE SPECTRAL LINES. Djenize S., Labat J., Sreckovic A., Labat 0., Platisa M., Puric J., Phys. Scr. 44, 148 .

4980. STARK BROADENING AND SHIFT OF SINGLY IONIZED ZINC AND CADMIUM SPECTRAL LINES. Djenize S., Sreckovic A., Labat J., Konjevic R., Popovic L., Phys. Rev. A 44, 410.

4981. STARK BROADENING AND SHIFT OF O II SPECTRAL LINES IN HIGHER MULTIPLETS. Djenize S., Sreckovic A., Labat J., Platisa M., Z. Phys. D 21, 295.

4982. STARK BROADENING REGULARITIES ALONG A HOMOLOGOUS SEQUENCE OF THE SECOND GROUP IN THE PERIODIC SYSTEM. Djenize S., Srieckovic A., Labat J., J. Quant. Spectrosc. Radiat. Transfer 46, 433.

4983. OBSERVATION OF ELECTROMAGNETICALLY INDUCED TRANSPARENCY IN COLLISIONALLY BROADENED LEAD VAPOR. Field J. E., Hahn K. H., Harris S. E., Phys. Rev. Lett. 67,3062 .

4984. SPECTRAL LINE SHAPE ARISING FROM COLLISIONAL INTERFERENCE BETWEEN ELECTRIC-DIPOLE-ALLOWED AND COLLISION-INDUCED TRANSITIONS. Gao B., Tabisz G. C., Trippenbach M., Cooper J., Phys. Rev. A 44, 7379.

4985. RESONANT MODIFICATION OF QUASISTATIC PROFILES OF SPECTRAL LINES OF HYDROGEN IN A PLASMA UNDER THE INFLUENCE OF NONCOLLINEAR HARMONIC ELECTRIC FIELDS. Gavrilenko V. P., Sov. Phys.--JETP 72, 624.

4986. EFFECT OF BACK REACTION ON BROADENING OF ATOMIC SPECTRAL LINES IN THE IMPACT APPROXIMATION. Grabowski B., Czainski A., Dimitrijevic M. S., J. Quant. Spectrosc. Radiat. Transfer 45, 181. 
4987. COMPARISON OF SECOND-ORDER IMPACT LINE SHIFTS. Griem H. R., Iglesias C. A., Boercker D. B., Phys. Rev. A 44, 5318.

4988. SPECTRAL LINE BROADENING FROM INDUCED RADIATIVE PROCESSES IN SOFT X-RAY LASER AMPLIFIERS. Griem H. R., Moreno J. C., Phys. Rev. A 44, 4564.

4989. HYDROGEN SPECTRAL LINES WITH THE INCLUSION OF DENSE-PLASMA EFFECTS. Günter S., Hitzschke L., Röpke G., Phys. Rev. A 44, 6834.

4990. MEASURED PRESSURE BROADENING AND SHIFT RATES OF THE $1.73 \mu \mathrm{m}\left(5 \mathrm{~d}[3 / 2]_{1}\right.$ $6 \mathrm{p}[5 / 2]_{2}$ ) TRANSITION OF XENON. Hebner G. A., Hays G. N., Appl. Phys. Lett. 59,537 .

4991. STARK EFFECT BROADENING OF BALMER LINES AT MEDIUM ELECTRON DENSITIES. Helbig V., Contrib. Plasma Phys. 31, 183.(Ger)

4992. PRECISE MEASUREMENT OF THE STARK SHIFT OF THE LITHIUM D 1 LINE. Hunter L. R., Krause D. Jr., Berkeland D. J., Boshier M. G., Phys. Rev. A 44, 6140.

4993. STARK BROADENING AND SATELLITE STRUCTURE OF HYDROGEN SPECTRAL LINES IN THE PRESENCE OF CONSTANT AND MICROWAVE ELECTRIC FIELDS. Klimchitskaya G. L., Pavlov Yu. V., J. Phys. B 24, 1899.

4994. TEMPERATURE DEPENDENCE OF SPECTRAL LINESHIFTS IN PRESSURE BROADENING. Kreye W. C., Kielkopf J: F., J. Phys. B 24, 65.

4995. THE SPECTRA OF RADIATION REDISTRIBUTION IN THE PRESENCE OF VELOCITY-CHANGING COLLISIONS. Kryszewski S., Nienhuis G., J. Phys. B 24, 3959.

4996. STARK BROADENING AND REGULARITIES OF IONIZED BROMINE SPECTRAL LINES. Labat 0., Djenize S., Puric J., Labat J. M., Sreckovic A., J. Phys. B 24,1251 .

4997. OPTICAL PUMPING OF Rb IN THE PRESENCE OF HIGH-PRESSURE ${ }^{3}$ He BUFFER GAS. Larson B., Häusser 0., Delheij P. P. J., Whittal D. M., Thiessen D., Phys. Rev: A 44, 3108.

4998. LINEAR ABSORPTION MEASUREMENTS OF PRESSURE BROADENING IN NEON. Lindsay A. C., Nicol J. L., Stacey D. N., J. Phys. B 24, 4901. 
4999. CALCULATIONAL ASPECTS OF THE STARK LINE BROADENING OF MULTIELECTRON IONS IN PLASMAS. Mancini R. C., Kilcrease D. P., Woltz L. A., Hooper C. F. Jr., Comput. Phys. Commun. 63, 314.

5000. SUPPLEMENTAL DATA ON LINE SHIFTS AND LINE PROFILES STUDIES IN AN INDUCTIVELY COUPLED ARGON PLASMA. Manning T. J., Palmer B. A., Hof D. E., Winefordner J. D., Spectrochim. Acta, Part B 46, 447.

5001. SHIFTS OF THE $\mathrm{H}_{\beta}$ LINE IN DENSE HYDROGEN PLASMAS. Mijatovic Z., Pavlov M., D jurovic S., Phys. Rev. A 43, 6095.

5002. INFLUENCE OF A d.c. MAGNETIC FIELD ON THE He I $447.1 \mathrm{~nm}$ LINE IN PURE HELIUM PLASMAS. Mijatovic Z., Pavlov M., Djurovic S., Vujicic B., Kobilarov R., J. Quant. Spectrosc. Radiat. Transfer 46, 557.

5003. SELF-BROADENING OF SINGLET LINES OF HELIUM. Mullamphy D. F. T., Peach G., Whittingham I. B., J. Phys. B 24, 3709.

5004. AN ALGORITHM FOR DETERMINING DISPERSION AND DOPPLER LINE WIDTHS FROM LIMITED EXPERIMENTAL DATA. Nigmatullin R. R., Shcherbakova N. K., Salakhov M. Kh., J. Quant. Spectrosc. Radiat. Transfer 45, 355.

5005. SPECTROSCOPY OF ATOMIC HYDROGEN IN DENSE PLASMAS IN THE PRESENCE OF DYNAMIC FIELDS: INTRA-STARK SPECTROSCOPY. Oks E. A., Böddeker St., Kunze H. - J., Phys. Rev. A 44, 8338.

5006. EXCITATION AND IONIZATION CHARACTERISTICS OF A d.c. ARGON PLASMA EVALUATED BY MEANS OF EMISSION AND ABSORPTION OF IRON LINES AND BROADENING OF THE HYDROGEN $\mathrm{H}_{\beta}$ LINE--EXPERIMENTAL FACTS. Pavlovic M. S., Pavlovic N. Z., Marinkovic M., Spectrochim. Acta, Part B 46, 1487.

5007. CALIBRATION OF THE STARK-BROADENING PARAMETERS FOR SOME He I LiNES. Perez C., de la Rosa I., de Frutos A. M., Mar S., Phys. Rev. A 44, 6785.

5008. STARK BROADENING OF SOME C I and C II LINES. Pérez C., de la Rosa I., de Frutos A. M., Mar S., Phys. Rev. A 44, 6948.

5009. THEORETICAL STUDY OF REDISTRIBUTION OF LIGHT IN Ca-He COLLISIONS. Pouilly B., J. Chem. Phys. 95, 5861. 
5010. REgUlARITIES OF STARK PARAMETERS ALONG THE PERIODIC TABLE. Puric J., Cuk M. , Dimitrijevic M. S., Lesage A., Astrophys. J. 382, 353.

5011. STARK BROADENING REGULARITIES WITHIN SUCCESSIVE IONIZATION STAGES IN KRYPTON AND XENON. Puric J., Djenize S., Labat J., Sreckovic A., Platisa M. , Contrib. P1asma Phys. 31, 63.

5012. EXCHANGE COLLISION KERNEL. Rogers G. L., Berman P. R., Phys. Rev. A 44, 417.

5013. BROADENING OF IONIC ISOLATED LINES BY INTERACTIONS WITH POSITIVELY CHARGED PERTURBERS IN THE QUASISTATIC LIMIT. Sahal-Bréchot S., Astron. Astrophys. 245, 322 .

5014. EFFECT OF NEAREST-NEIGHBOR IONS ON EXCITED IONIC STATES, EMISSION SPECTRA, AND LINE PROFILES IN HOT AND DENSE PLASMAS. Salzmann D., Stein J., Goldberg I. B., Pratt R. H., Phys. Rev. A 44, 1270.

5015. QUANTUM ELECTRODYNAMICAL THEORY FOR THE NATURAL SHAPE OF THE SPECTRAL LINE. Shabaev V. M., J. Phys. A 24, 5665.

5016. COLLISION BROADENING OF THE $4 \mathrm{~s} 4 \mathrm{p}\left({ }^{3} \mathrm{P}^{\circ}\right)-4 \mathrm{~s} 5 \mathrm{~s}\left({ }^{3} \mathrm{~S}\right)$ LINE OF CALCIUM PERTURBED BY HYDROGEN AND COLLISION INDUCED TRANSITIONS AMONG THE $4 \mathrm{~s} 4 \mathrm{p}$ $\left({ }^{3} \mathrm{P}^{\circ}\right)$ STATES. Spielfiedel A., Feautrier N., Chambaud G., Levy B., J. Phys. B 24, 4711 .

5017. LINE SHAPES OF HYDROGEN AND HYDROGENIC IONS IN PLASMAS. Stehlé C., J. Phys. IV, Colloq. C1 1, C1-121.

5018. IMPACT-BROADENED CROSS SECTIONS OF RYDBERG LEVELS OF ALKALINE-EARTH ATOMS BY COLLISION WITH RARE GASES AT THERMAL ENERGY. Sun J.-Q., Matthias E., Heber K.-D., West P. J., Güdde J., Phys. Rev. A 43, 5956.

5019. DETERMINATION OF THE ELECTRON DENSITY FROM THE STARK BROADENING OF BALMER BETA-COMPARISON BETWEEN EXPERIMENT AND THEORY. Thomsen C., Helbig V., Spectrochim. Acta, Part B 46, 1215.

5020. OBSERVATION OF CONTINUUM ABSORPTION SPECTRA IN FAR WINGS OF THE Yb RESONANCE LINE BROADENED BY $\mathrm{He}, \mathrm{Ne}, \mathrm{Ar}, \mathrm{Kr}$, Xe, AND Yb. Ueda $\mathrm{K}$., Sonobe 0., Chiba H., Sato Y., J. Chem. Phys. 95, 8083. 
5021. OBSERVATION OF FAR-WING ABSORPTION BANDS OF THE Ba $6 \mathrm{~s}^{2}{ }^{1} \mathrm{~S}_{0}-5 \mathrm{~d} 6 \mathrm{p}{ }^{1} \mathrm{P}_{1}$ LINE BROADENED BY RARE GASES. Ueda K., Sotome H., Sato Y., J. Chem. Phys. 94, 1903.

5022. OBSERVATION OF PAIR ABSORPTION AND SELF-BROADENING IN Ba VAPOR. Ueda K., Sotome H., Sato Y., J. Chem. Phys. 94, 1907.

5023. SHIFT AND WIDTH OF THE LYMAN- $\alpha$ LINE OF NEUTRAL HYDROGEN DUE TO ELECTRON COLLISIONS. Unnikrishnan K., Callaway J., Phys. Rev. A 43, 3619.

5024. STARK BROADENING OF THE He I $4471 \AA$ LINE AND ITS FORBIDDEN COMPONENT AT HIGH ELECTRON DENSITIES. Uzelac N. I., Stefanovic I., Konjevic N., J. Quant. Spectrosc. Radiat. Transfer 46, 447.

5025. MEASUREMENTS OF THE CURRENT DENSITY IN ARC CATHODE SPOTS FROM THE ZEEMAN SPLITTING OF EMISSION LINES. Voge1. N., Jüttner B., J. Phys. D 24, 922.

5026. EFFECTS OF ELECTRIC MICROFIELDS ON ARGON DIELECTRONIC SATELLITE SPECTRA IN LASER-PRODUCED PLASMAS. Woltz L. A., Jacobs V. L., Hooper C. F. Jr., Mancini R. C., Phys. Rev. A 44, 1281.

\section{2}

5027. STATE-TO-STATE RATE CONSTANTS FOR QUENCHING OF XENON 6p LEVELS BY RARE GASES. Alford W. J., J. Chem. Phys. 96, 4330.

5028. SPECTRAL LINE SHAPES IN ASTROPHYSICS AND PLASMA PHYSICS. Atanackovic-Vukmanovic 0., Dimitrijevic M. S., Publ. Obs. Astron. Belgrade No. 43, Ch. 11.2, 76-98.

5029. THE OPTICALLY THICK C III SPECTRUM. I. TERM POPULATIONS AND MULTIPLET. INTENSITIES AT LOWER OPTICAL DEPTHS. Bhatia A. K., Kastner S. O., Astrophys. J., Supp1. Ser. 79, 139.

5030. THE ADIABATIC MECHANISM OF THE COLLISIONAL BROADENING OF RYDBERG STATES VIA A LOOSELY BOUND RESONANCE STATE OF AMBIENT GAS ATOMS. Borodin V. M., Kazansky A. K., J. Phys. B 25, 971.

5031. STARK BROADENING PARAMETER TABLES FOR Be II LINES OF ASTROPHYSICAL INTEREST. Dimitrijevic M. S., Sahal-Bréchot S., Bul1. Astron. Belgrade No. 145,65 . 
5032. STARK BROADENING PARAMETER TABLES FOR Ca II LINES OF ASTROPHYSICAL INTEREST. Dimitrijevic M. S., Sahal-Bréchot S., Bull. Astron. Belgrade No. 145,83 .

5033. MEASURED STARK WIDTHS OF B I, B II, B III, AND Na I SPECTRAL LINES. Djenize S., Sreckovic A., Labat J., Platisa M., Phys. Scr. 45, 320.

5034. MEASURED STARK WIDTHS OF DOUBLY AND TRIPLY IONIZED SILICON SPECTRAL LINES. Djenize S., Sreckovic A., Labat J., Puric J., Platisa M., J. Phys. B 25, 785 .

5035. STARK SHIFTS OF SINGLY-IONIZED NITROGEN SPECTRAL LINES. Djenize S., Sreckovic A., Labat J., Astron. Astrophys. 253, 632.

5036. H ATOM PLASMA DIAGNOSTICS: A SENSITIVE PROBE OF TEMPERATURE AND PURITY. Dunlop J. R., Tserepi A. D., Preppernau B. L., Cerny T. M., Miller T. A., Plasma Chem. Plasma Process. 12, 89.

5037. LASER-INDUCED COLLISIONAL ENERGY TRANSFER: HIGH-ACCURACY MEASUREMENT OF THE SPECTRAL LINE SHAPE IN WEAK-FIELD REGIME. Fini L., Buffa R., Pratesi R., Bambini A., Matera M., Mazzoni M., Europhys. Lett. 18, 23.

5038. FOREIGN GAS BROADENING AND SHIFT IN THE LEAD RESONANCE LINE AT $\lambda=283.3$ nm. Kötteritzsch M., Gries W., Hese A., J. Phys. B 25, 913.

5039. DOPPLER-SHIFTED LINE PROFILES FROM SPHERICALLY EXPANDING PLASMAS. Moreno J. C., Goldsmith S., Griem H. R., J. Opt. Soc. Am. B 9, 339.

5040. REINVESTIGATION OF SOME OF THE AUTOIONIZING LEVELS IN THE SPECTRUM OF Cu I. RajaRao P. M., Padmanabhan S., Krishnamurty G., Raja Sekhar B. N., J. Quant. Spectrosc. Radiat. Transfer 47, 113.

5041. PRESSURE BROADENING OF THE CALCIUM $657.3 \mathrm{~nm}$ LINE BY HELIUM, NEON AND ARGON. Röhe-Hansen J., Helbig V., J. Phys. B 25, 71.

5042. SPIN-EXCHANGE FREQUENCY SHIFT IN A CESIUM ATOMIC FOUNTAIN. Tiesinga E., Verhaar B. J., Stoof H. T. C., Bragt D. van, Phys. Rev. A 45, R2671.

5043. A METHOD FOR DETERMINING THE COLUMN DENSITY FROM THE PRESSURE-BROADENED RESONANCE LINES. Ueda K., Sonobe O., Chiba H., Sato Y., Namioka T., Rev. Sci. Instrum. 63, 1690. 
5044. MEASUREMENTS OF LINE BROADENING OF B V $\mathrm{H}_{\alpha}$ and $\mathrm{L}_{\delta}$ IN A LASER-PRODUCED PLASMA. Wang J. S., Griem H. R., Huang Y. W., Böttcher F., Phys. Rev. A 45, 4010.

5045. REGULARITIES IN EXPERIMENTAL STARK SHIFTS. Wiese W. L., Konjevic N., J. Quant. Spectrosc. Radiat. Transfèr 47, 185. 
Abadie D.

$3879,4086,4358,4816$

Abbas A.

$4655,4656,4657$

Abd El-Aal Z. A.

4655

Abdel-Aal Z. A.

$4656,4657,4770$

Abdulla A. G. H.

4869

Ackerhalt J. R.

4823

Ackermann U.

3937,4255

Adachi A.

3185

Adachi Y.

$4578,4725,4805$

Adcock J. C. Jr.

3782,3938

Adler $\mathrm{H}$.

4412

Adler H. G.

4948

Aferenko E. V.

4762

Afonin S. V.

4125

Agarwal G. S. 3901,4763
Agladze N. I.

4539

Agresti A.

4658

Akazaki M.

4705

Akhmedov E. Kh.

4256

Akhmedzhanov R. A.

4126

Akhrem A. A.

4001

Akul'shin A. M.

3783

Al-Hilfy A.

3784

Al-Saqabi B. N. I . 4540

Al - Shiraida Y. S . 3242,3426

Alam R. C.

4857

Alastuey A.

4127,4949

Alaterre $\mathrm{P}$.

4257,4431

Alber $G$.

$4258,4259,4260,4413$

Aleksandrov E. B.

$3596,4128,4261$ 
Author. Ref. No. from Part 3.

Aleksandrovich $\mathrm{K}$. V.

3100,3126

Alekseev V. A.

3101,3127

Alexiou S.

$4662,4858,4859$

Alford W. J.

$3939,4057,4129,4262,4419$, 5027

Ali Y. M.

3684

Alipieva E. A.

3102

Alkemade C. Th. J.

$3183,3230,3579,3681,3682$, $3920,4073,4523,4623,4624$, 4625

Allano D.

3701

Allard F.

4860

Allard N. F.

$3321,3427,3473,3500,3785$, $3786,3940,4130,4263,4541$, $4659,4660,4861,4862,4950$, 4951

Allegrini $M$.

4895

Allen L.

3981

Alley W. E.

3787

Alvarez II R. J.

4918
Author. Ref. No. from Part 3 .

Alvarez J. M.

$3107,3128,3259,3437,4211$

Amare J. C.

3107,4211

Amini. B.

4414

Aminoff C. G.

$3369,3892,3941$

Amir A.

4585

Andersen N.

4129,4262

Andersen T. B.

3428

Anderson L.

4564

Anderson V. E.

3363

Andreev E. A.

3597

Andretta V.

4952

Angelie A.

4415

Anstee S. D.

4953

Anufrienko A. V.

4863

Apai P.

4735

Apruzese J. P.

$4264,4265,4954$ 
Author. Ref. No. from Part 3.

Arata Y.

$4131,4132,4266,4542,4543$

Araujo J. M. R.

3598

Arbadji S. A.

3788

Archirel P.

4676

Arditi M.

3307

Argawal G. S .

4544

Arnoldus H. F.

4267,4545

Arnous E.

3942

Artru M. C.

4715

Ashkenazy $\mathrm{J}$.

4955

Atadzhanov M. R.

3789

Atamas S. N.

4133

Atanackovic-Vukmanovic 0 .

4884,5028

Atkinson J. B.

3933

Aubes $M$.

3970

Audebert P.

$4134,4257,4431$
Author. Ref. No. from Part 3.

Auerbach J. M.

3243

Auluck S. K. H.

4831

Averbukh I. Sh.

4628

Ayers E. L.

4661

Babaev A. S.

3244

Babaev V. S.

$3129,3130,3244,3429$

Bacchus-Montabonel M. C. 4268

Bachet G.

3537

Bacis R.

4969

Bäckström $M$.

4135

Bacri J.

4956

Badie J. M.

4864, 4956

Baessler P.

3245,3430

Bailey D. S .

3243

Baird J. C.

4662, 4859

Baird J. P.

3246 
Author. Ref. No. from Part 3.

Baird P. E. G.

3247,4817

Bakaev D. S .

3131,3599

Baker E. A. M.

3132,3248

Baklanov E. V.

3600,3601

Baklanov Ye. V.

3249

Bakshi P.

4865,4911

Bakshi V.

$4764,4765,4766$

Balashov A. A.

4539

Baldwin K. G. H.

$3286,4136,4269,4416,4723$

Ballagh R. J.

$3103,3154,3446,3452,3779$,

3804,4778

Balling L. C.

3790

Bambini A.

4658,5037

Band Y. B.

4483

Banon J.

4137

Banon J. M.

$4270,4546,4767,4768$

Baravian G.

4547
Author. Ref. No. from Part 3 .

Barbeau C.

4928

Bardet J. P.

$3943,4417,4866,4943$

Bardinov A. A.

4418

Barkov L. M.

4769

Barnard A. J .

$3315,3368,3612,4222$

Baronets P. N.

4957

Baronnet J. M.

3250

Barr D

3759

Baryshenkov F. F.

3602

Baryshnikov F. F.

3431

Basha T. S.

$4655,4656,4657,4770$

Bassalo J. M.

3133, 3432, 3598, 3603, 3791

Bassani F.

3944

Bassini M.

3261

Bassyouni A. H.

$3433,3604,3792,3945$

Bastian J .

3942 
Author. Ref. No, from Part 3.

Batal A.

3605

Batenin V. M.

3251

Bates R. H. T.

4608

Bathia K. S.

4271

Batyghin V. V.

3252

Batygin V. V.

$3104,3105,3106,3134,3135$,

$3253,3254,3434,3793,3946$, 3947

Batygin Vit. V.

3435

Batygin V1. V.

3435

Bauder U. H.

4501

Bava E.

3948

Baylis W. E.

3949

Beckers J. M.

3136

Behmenburg $\mathrm{W}$.

$3207,3255,3503,3606,4509$, 4573

Behnke J. F.

4138

Behringer $\mathrm{K}$.

3137
Author. Ref. No. from Part 3.

Beilin E. L.

4771

Bekefi G.

3396

BelBruno J. J .

3607,3774

Belov V. N

$3608,3609,3610,3794$

Belsley $M$.

$4262,4419,4420,4548,4968$

Belsley M. S.

4663

Bely-Dubau F.

3256,3257

Belyaev M. V.

3600

Ben Lakhdar Z.

3890

Ben-Reuven A.

3611,3800

Benesch $W$.

4139,4661

Bengtson R. D.

$3347,3348,3521,3950,4077$, 4421

Beniaminy I.

3812

Benjamin R. D.

4664

Bennett W. R. Jr.

3138,3487

Benred jem D.

4470,4491 
Author. Ref. No. from Part 3.

Benred jem D. E.

4867

Berard M.

3951

Berezin A. B.

3952,4418

Berezin I. A.

3100,3126

Berkeland D. J.

4992

Berkovsky M. A.

4868

Berman P. R.

$3139,3258,3338,3424,3436$, $3509,3685,3760,3795,4658$, 5012

Bernabeu E.

$3107,3128,3259,3437,4211$, 4767,4768

Bernard J. E.

3612

Bernu B.

4422

Beroff K.

$3142,3262,3302$

Bertschinger $G$.

3467

Bertuccelli D.

4958, 4959

Bertuccelli $G$.

4682, 4781, 4958, 4959, 4960

Bessho S.

3197
Author. Ref. No. from Part 3.

Beuc R.

$3755,3796,3797,4140$

Beverini N.

$3613,4272,4744$

Bhatia A. K.

3496,5029

Bhatia K. S.

4869

Bialas J.

3614

Bielski A.

$3140,3141,3260,3438,3439$,

$3511,3615,3616,3617,3705$,

$3875,3876,3953,3954,4205$,

4273, 4276, 4354, 4423, 4532,

$4551,4652,4870,4961,4962$

Bieniek R. J .

$3955,4274,4275,4549$

Bilinska D.

4205

Billou E.

4864

Biraben F.

3090 , 3142, 3178, 3261, 3262,

$3302,3870,4895,4963$

Biraud Y. G.

$3427,3785,3940,4130,4263$,

4541,4659

Birnbaum G.

3263, 4141

Bitter M.

3264,3618

Bjorkholm J . E.

$3258,3338,3509$ 
Blades M. W.

$4279,4550,4557$

B1aha M.

$3182,3300,3810,4665,4871$, 4900

Bleize J. J.

4394

B1och D.

3821

Bobatto G. E.

4727

Bobin J. L.

4866

Bobkowski R.

$3615,3953,3954,4059,4276$,

$4423,4551,4570,4789$

Böddeker St.

5005

Boédo J .

4421

Boercker D. B.

$3956,3957,4142,4295,4317$, $4552,4894,4987$

Bogdanov Yù. V.

$4424,4553,4666,4772$

Boiko V. A.

$3265,3619,4143$

Bokun V. C.

4840

Bombarda F.

4773

Bommier V.

$4975,4976,4977,4978$
Boriev I. A.

3958

Borisova N. F.

3905, 4247

Borodin V. M.

4667, 4964, 5030

Borstel M. V.

4668

Boshier M. G.

4992

Böttcher F.

4554, 4617, 4669, 4695, 4907, 5044

Botzanowski Y.

$4235,4385,4386$

Bouchoule A.

3367

Boulet C.

3143

Boumans P. W. J. M.

4425,4555

Bourdin E.

3250

Bourke P.

3592

Bousquet $C$.

$3266,3440,3622,3960,4144$, 4426,4670

Bower J.

3540

Böwering $\mathrm{N}$.

3959,4145 
Author. Ref. No. from Part 3 .

Bowman N. J.

3144

Boyarskii K. K.

3102

Boyer D. W.

3145

Brablec A.

$4277,4556,4671$

Bracco G.

3620

Bradley K. R.

4829

Bradshaw J .

3540

Bragt $D$. van

5042

Brandt $T$.

3621

Bras N.

$3266,3440,3622,3960,4144$

Brault J. W.

4297

Brault P.

4593, 4672

Bravo-Ortega A.

4807

Bredice F.

4682,4781

Breene R. G. Jr.

3623

Breger P.

$3477,3478,3479,3670,3671$,

$3844,4669,4804,4905$
Author. Ref. No. from Part 3.

Breton C

3441,3620

Brezna E.

3267

Brillet W. $-\ddot{U}$ L.

$3442,3633,3634,3971$

Bromage G. E.

3336

Brooks N. H.

4000

Brooks W. S. C.

4673

Bruce D. M.

$3146,3798,3961,4271$

Bryl K.

3616

Brym S.

4961

Buchwald R.

3467

Buffa $G$.

3962,4427

Buffa R.

4965,5037

Bukhvalov A. V.

3946

Bukshpun L. M. 4133

Bukvic S .

4081

Bulyshev A. E. 4674 
Bunkin F. V.

4143

Burgess D. D.

$3132,3147,3148,3221,3248$, $3268,3443,3624,3625,3799$, $4074,4136,4269,4337,4345$, 4416,4723

Burggraf $\mathrm{H}$.

4003

Burgmans A. L. J .

3806

Burnett $\mathrm{K}$.

$3247,3444,3445,3446,3452$, $3574,3779,3800,3804,3863$, $3939,4057,4129,4262,4419$, 4420,4839

Burrell K. H.

4000

Burton L. L.

4550,4557

Burtsev V. A.

4418

Busca G.

3413

Bussery B.

4969

Butaux J .

$3269,3270,3447$

Butikov E. I.

4146

Butler K.

4836,4837

Butler L. R. P. 3466
Bykova N. G.

4957

Bzenic S. A.

4966

Cabral-Prieto A.

4807

Caby $M$.

$3527,3528,3719,4491$

Cagigal M. P.

4171

Cagnac B .

$3090,3112,3178,3261$

Cahuzac $\mathrm{Ph}$.

3448

Cajko J.

3083

Calisti A.

4558, 4675, 4872, 4873, 4912, 4934

Callaway $\mathrm{J}$.

$4942,4967,5023$

Calvert J. G.

3340

Cameron D. G.

4147

Camparo J. C .

3963

Ganer $M$.

4955

Capek V.

4774

Capozzi F.

4968 
Author. Ref. No. from Part 3.

Cappelli M. A.

4148,4559

Capron B. A.

4428

Cardenoso V.

$4447,4448,4580,4775,4796$

Carill on A .

$3312,3313,3852,4479,4910$

Carlhoff C.

4278,4429

Carlsten J. L.

3208,3381

Carrington C. G .

3088

Caste M. C.

4098

Castell R.

$3900,3964,4032$

Castex M. C.

4051

Catherinot A.

3820

Cattani M.

$3133,3432,3598,3603,3791$, 3801

Cauble R.

$3802,3965,3966,4265$

Caughlin B. L.

4279,4550

Ceglio N. M.

4284

Cerny D.

4969
Author. Ref. No. from Part 3 .

Cerny T. M.

5036

Ch'en S. Y.

$3414,3473,3655$

Chaika M. P.

$3513,3610,3789,4334$

Chambaud G.

$3271,4430,4676,4932,5016$

Chan L. K. P.

4149

Chan S. - K

4776

Chang R. K.

4572

Chapelle J.

$3111,3165,3169,3174,3292$,

$3411,3468,3469,3969,4106$,

$4281,4282,4481$

Chapline G.

3787

Charton G.

$3658,3659,4174,4453$

Chatham R. H.

3449

Chebotayev V. P.

3249,3967

Chen C. J.

3149

Chen D. A.

4644

Chen S. Y.

3150 


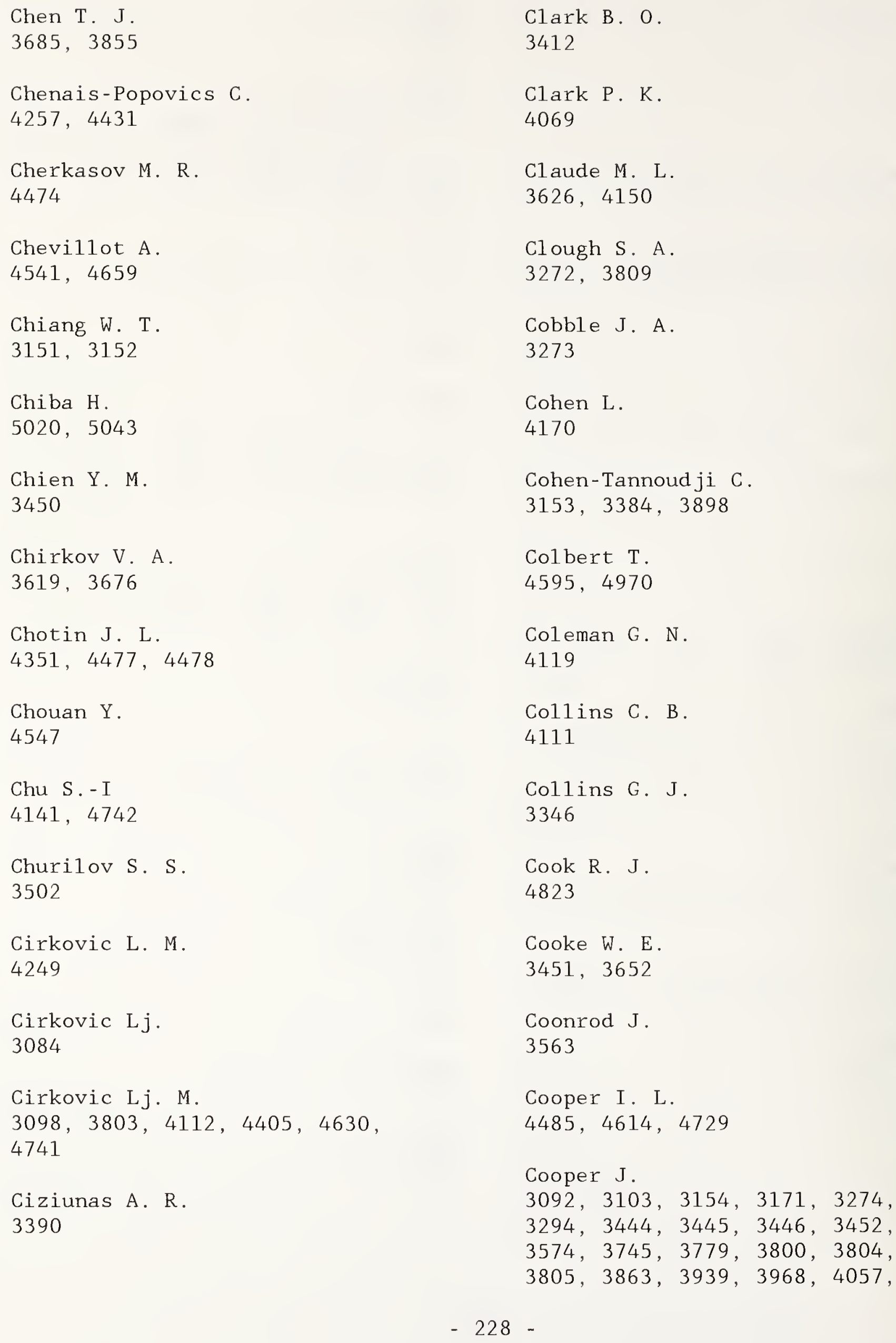


4129, 4234, 4259, 4260, 4262, $4355,4413,4419,4420,4465$, $4548,4561,4639,4663,4749$, $4750,4777,4778,4827,4913$, 4984

Cope D.

$4560,4677,4678$

Copeland G. E.

4008

Cornelissen H. J.

3806

Corney A.

$3088,3108,3627,3807$

Cornille M.

3817

Coudert J. F.

3250

Couillaud B.

3700

Coulaud G.

$3169,3292,3468,3469,3527$, $3528,3719,3884,4214,4470$, 4491,4867

Couris S.

4331

Coutts J.

4561,4663

Cram L. E.

4280

Crampton S. B.

4647

Cremers R. M. M.

4503

Crumley R. J .

3457
Cuk M.

$3699,3871,4048,4083,4223$, $4224,4371,4372,4629,4736$, $4738,4739,5010$

Cullmann E.

3155

Curzon F. L.

3612

Cyr N.

3921,3922

Czainski A.

4986

Czernichowski A.

$3159,3969,4281,4282,4481$

Czerwosz E.

3661

Czub J .

3628,4874

Czuchaj E.

$3275,3453,4151,4152,4380$

D'Etat B .

$4348,4562,4563$

D'yachkov L. G.

4679,4875

Dabkiewicz P.

3459

Dagenais $M$.

3629,3808

Dalgarno A.

4141

Dalibard J .

3898 
Damany $\mathrm{H}$.

3327,3328

Damaschini R.

$3156,3247,3448,3630,3631$

Damelincourt J. J .

3157,3970

Danby $G$.

4729

Danzmann $\mathrm{K}$.

4432

Däppen $W$.

4564

Darowicki H.

3260

Darrigo R.

3701

Das P. P.

3471

Das T. P.

3896

Datla R. U.

3276

Datskou I.

4896

Dattagupta S.

4283

Davidovich L.

3158

Davies R. W.

3809

Davis $\mathrm{J}$.

$3462,3488,3632,3810,4265$, 4665,4871
Davis S. J.

3983,4069

Davy $P$.

3367,3820

De Frutos A. M.

$4926,5007,5008$

De Galan L.

4846

De Groot J. J.

4407,4635

De 1a Rosa I.

5007,5008

De La Rosa M. I.

4926

De Loos-Vollefregt M. T. C.

4846

De Marchi A.

3948

De Michelis C.

3441

Deavor J. P.

4172

Deckman H.

3423,3592

Dehesa J. S.

3811

DeHoog F. J.

3346

Deinezhenko A. L.

4680

Delamater N. D.

4284, 4906 
Author. Ref. No. from Part 3.

Delettrez J.

3423

Delheij P. P. J.

4997

Del houme $M$.

$3633,3634,3971$

Delone N. B.

3109

Delpech J. F.

3558

Delsart C.

3454

Demkin V. P.

3175

Demura A. V.

3091,4863

Den S. - J .

4829

Deng C. - H.

3277

Denize S.

4919

Denton M. B.

4735

Deridder $G$.

3580

Derzhiev V. I.

4143

Desyatnik G. A.

3291

Deutsch C.

$3668,3669,3842,3843,3972$, $4013,4153,4178,4179,4312$, 4876
Author. Ref. No. from Part 3.

Deutsch M.

3812

Devdariani A. Z.

$4285,4286,4681,4779$

Devi V. M.

3471

Devyatov A. M.

3586

Dewhurst R. J .

3455,3456

DeWitt H. E.

4030,4318

Dhali S. K.

3457

Dharma-wardana M. W. C.

$3458,4369,4433,4927$

Di Lieto A.

$4359,4427,4484$

Di Rocco H. O.

4682, 4780, 4781, 4877, 4878,

$4958,4959,4960$

Diatta C. S.

3159

Diaz M. A.

4683,4879

Dickinson A. S .

$4361,4383,4485,4614,4729$

Dickinson P. H. G.

4322

Dietz K. J.

3459

Dietz Th.

3568 
Di jkerman H. A.

4523

Dimarcq C .

4866,4943

Dimitrijevic M. S.

$3160,3161,3162,3209,3211$,

$3212,3278,3279,3280,3281$,

$3282,3326,3371,3460,3635$,

$3636,3637,3638,3639,3640$,

$3694,3813,3814,3815,3816$,

$3817,3818,3973,3974,3975$,

$3976,3977,3978,4041,4113$,

$4154,4155,4156,4157,4158$,

$4196,4197,4287,4288,4289$,

$4290,4291,4292,4399,4400$,

$4401,4434,4435,4436,4437$,

$4438,4439,4440,4565,4566$,

$4567,4684,4685,4686,4715$,

$4756,4782,4783,4784,4785$,

$4786,4813,4814,4848,4880$,

$4881,4882,4883,4884,4885$,

$4886,4887,4888,4893,4971$,

4972, 4973, 4974, 4975, 4976,

$4977,4978,4986,5010,5028$,

5031,5032

Djenize S.

$4630,4631,4687,4736,4737$,

$4738,4739,4740,4741,4787$.

$4889,4890,4891,4892,4933$,

$4979,4980,4981,4982,4996$,

$5011,5033,5034,5035$

D jeu N.

3589

D julgerova R.

3110

Djuric Z .

4784

D jurovic $S$.

4613, 4688, 4689, 4690, 4788,

$4801,4849,4893,5001,5002$
Dmitrieva I. V.

3979

Dobrichev $\mathrm{V}$.

4159

Dodsworth B.

3089

Dokurno W.

$3438,3615,3616,3617$

Donin V. I.

3461

Donohue D. E.

4167

Dragalov V. V.

4568

Drake J. J .

4637,4747

Drawin H. W.

$3163,3164,3283,3284,3406$,

$3641,3752,3819,3914$

Drummond J. R.

4293

Dubkov V. I .

4160

Dubourg I .

4441, 4442

Dubreuil B.

$3165,3367,3820,3980,4294$, 4498

Ducloy $M$.

3821

Duff J. W.

4101 
Author. Ref. No. from Part 3 .

\section{Dufty J .}

4029

Dufty J. W.

$3956,4295,4552,4894$

Dugan C. H.

3351

Duley W. W.

$3146,3798,3961,4271$

Dunaev V. V.

3285

Dunlop J. R.

5036

Dupont-Roc J .

3384,3898

Düren R.

3822

Durrant A. V.

$4161,4162,4480$

Duston D.

3462

Dyachkov L. G.

4569

Dygdala R.

3953,3954

Dygdala R. S .

$3876,4570,4571,4691,4692$,

4789

Ebeling $W$.

4790,4914

Eberly J. H.

3166

Eberz J.

4163
Author. Ref. No. from Part 3 .

Eckart M. J .

3246,3286

Edmonds A. R.

3576

Egorov V. K.

4164

Ehrich H.

$3287,3288,3463,3666$

Eicher C. A.

3981

Eickmans J. H.

4572

Eigenson E. B.

4360

Einwohner $\mathrm{T}$.

4092

E1-Farra M. A.

3982

Elias L. R.

4585

Ely D.

3758

Engel'sht V. S.

3303

Engleman R. Jr.

3167,3983

Erchov

3250

Erez G.

$3115,4241,4582$

Erickson G. J .

3464 
Ermers A.

4573

Ernst $\mathrm{K}$.

4272

Esrom H.

3642

Evans R. G.

3318

Evensky D. A.

4296

Everett D.

3268

Ewart P.

$3823,4420,4968$

Exton R. J .

3168,4574

Fabrikant I. I.

4964

Fabry $M$.

4443,4618

Faenov A. Ya.

3265,3619

Fafurina E. N.

$3130,3244,3429$

Faid K.

4444

Faires L. M.

4297

Farley J. W.

3643

Fassel V. A.

3329,3880
Fauchais $\mathrm{P}$.

3250

Fazakas J.

4693

Feautrier N

$3317,3576,3633,3634,3637$, $3815,3817,3971,3973,4102$, $4239,4240,4388,4389,4396$, $4397,4841,4842,4932,4936$, 5016

Fedorova T. N.

4301, 4306

Feldman U.

4619

Ferguson A. I.

3297,3330

Ferray $M$.

$3391,3465,3559,3560,3644$, $3762,4441,4442$

Ferreira N. P.

3466,3645

Ferrell W. R.

4575

Field J. E.

4983

Filatov P. P.

3575

Filinov V. S.

3504,3697

Findeisen $M$.

4002

Fini L.

5037 
Author. Ref. No. from Part 3.

Finken K. H.

$3289,3290,3467,3937,4255$

Finkenthal $M$.

3441

Firstova N. M.

4165

Firth W. J.

3614

Fisanick G. J.

4167

Fishman I. S .

$3291,3483,3646,3742,4093$,

$4376,4467,4508,4576,4633$, 4743

Fiutak J .

3628,4874

Flesch J.

4213

Fletcher S. J.

4857

Fleurier C.

$3111,3169,3292,3468,3469$,

$4080,4166,4298,4499,4710$

Flinsenberg $\mathrm{H}$. J .

3235

Flores-Llamas H.

4807

Flusberg A.

3170,3293

Ford G. W.

4445

Foukal P.

4577
Author. Ref. No. from Part 3.

Fourcade N.

3470,3647

Fournier P. R.

$3674,3832,4173$

Fox R. F.

4444

Fradkin E. E.

3575

Fragnac P.

3970

Fraile J.

4303

Francesconi M.

4744

Francisco J. S.

3648

Frankenberger R.

4115

Freeman A. J.

3507

Freeman G. H. C.

4322

Frerichs M. R.

4791

Freudenstein S. A.

3171,3294

Freund R. S .

4167

Fridovich B.

3471,4168

Friedberg R.

4792 
Author. Ref. No. from Part 3 .

Friedman M.

3649

Frish M. S.

$3311,3486,3678,4320,4321$

Froment N. M.

3650

Frommhold L.

4141

Frueholz R. P.

3963

Fu F. S.

4012

Fuhr J. R.

3172

Fujimaki s.

4578

Fujimoto $\mathrm{T}$.

$3295,3578,3651,3824,4244$, 4299

Fujita J .

3651,3710

Fujiwara M.

3710

Fukuda K.

$3123,3295,3578,3825,3916$, $3917,3918,3919,4244$

Fukuda Y.

3984

Fukushima H.

4192

Fukuyo H.

$3118,3193,3324,3495$
Author. Ref. No. from Part 3 .

Fukuzo Y.

3663

Fulton R. D.

4634

Furuhashi H.

4463

Gabriel A. H.

3256,3257

Gainutdinov R. Kh.

4446, 4579

Gaisinskii I. M.

4762

Gaisinsky I. M.

$3985,4300,4694,4793$

Galatry L.

3143

Gallagher A.

$3173,3442,3449,3986,4024$,

$4025,4036,4368,4828$

Gallagher A. C.

3590

Gallagher T. F.

$3451,3558,3652,4395$

Gallardo M.

4682, 4781

Ganapathy S.

3542

Gao B.

4984

Gaponov V. A.

4125

Garifo L.

3200,3343 
Author. Ref. No. from Part 3.

Garreau J. C.

4895

Garrett W. R.

4575,4896

Gauthier J. C.

$3296,3653,4134,4257,4431$

Gavrilenko V. P.

$3987,4495,4694,4897,4985$

Gavrilov V. E.

4301

Gavrilova T. V.

4301

Gawron A.

$4695,4794,4905$

Gay J. C.

3585

Gburski Z .

3988,4169

Gee J.

3846

Geiger J .

3423

Geindre J. P.

$3296,3653,4134,4257,4431$

Geisler M.

$3654,3989,4302$

Gel bwachs J. A.

4795

Gelfand J.

3607,3774

Gendrin A. G .

4125
Author. Ref. No. from Part 3.

Gendzhov S .

3923

George T. F.

4545

Georgiou G. E.

3472

Gershun M. A.

4247

Giacobino E.

$3142,3262,3302,3870$

Giannella R.

4773

Gietzel P. C.

3203

Gigosos M. A.

$3344,3990,4242,4303,4304$,

4313, 4447, 4448, 4449, 4450,

$4451,4521,4580,4775,4796$

Gilbert D.

3401

Gilbert D. E.

3473,3655

Gilbert R. G.

3648

Giles R. G.

3656,3826

Gilles D.

4415,4898

Gillian L.

4577

Ginzburg M. D.

$3206,3723,3889,4217$ 
Author. Ref. No. from Part 3.

Girardeau M. D.

3991,3992

Girlanda R.

3944

Giry L.

4866,4943

Gislason E. A.

4085

Glab W.

$3717, \quad 3827$

Glaros S. S.

3243

Glasser J .

3174

Glavatskikh N. A.

4202

Glavonic V.

3213,3736

Glavonjic V.

$3379,3380,3553$

Gleizes A.

4393

Glisic S. M.

3803

Glowienka J. C.

3273

Godone A.

3948

Godunov A. L.

4256,4863

Goldbach C.

3345
Author. Ref. No. from Part 3 .

Goldbach C1.

$3520,3653,3828,3993$

Goldberg A.

4581

Goldberg I. B.

5014

Goldman M.

3264

Goldsmith J. E. M.

$3297,3330,3417$

Goldsmith S.

$4170,4824,4899,5039$

Golub I.

4582

Goly A.

$3829,3830,3994,4452,4583$

Gombert M. M.

$3842,3843,4013,4312$

Gombert M. - M.

4178,4179

Gomez M. T.

4584,4952

Gonzalez F.

4171

Gonzalez M. A.

4797

Gonzalez V. R.

4797,4926

Goode S. R.

4172

Gorchakov L. V. 3175 
Author. Ref. No. from Part 3.

Gordon E. B.

3958

Gornik W.

3657

Gornyi M. B.

$3104,3134,3135,3253,3254$,

3435,3995

Goto S.

4319

Goto T.

4463

Goudzwaard M. P.

4846

Gounand $\mathrm{F}$.

$3831,3832,4173$

Gover A.

4585

Grabowski B.

3996, 4305, 4586, 4587, 4784,

4921,4986

Grand jouan N.

3296,3653

Granier J .

$3658,3659,4453$

Granier L.

4174

Granier R.

$3658,3659,4174,4453$

Granneman E. H. A.

3680

Gravilov V. E.

4306
Author. Ref. No. from Part 3.

Gravilova T. V.

4306

Gray C. G.

3988,4169

Grdlichko D. P.

3176

Greef L. G. M. de 3236

Green W. B .

4602

Greene R. L.

$3298,3833,3834,3835,3997$, $4454,4496,4732,4733,4734$, 4913

Greenwald M.

3563

Greiner F.

4806

Grieble D. L.

3474,3539

Griem H. R.

$3151,3152,3188,3276,3299$,

$3300,3359,3476,3660,3782$,

$3836,3860,3938,3965,3966$,

$3998,3999,4170,4265,4307$,

$4455,4617,4634,4696,4697$,

$4707,4708,4798,4824,4850$,

$4900,4901,4907,4908,4987$,

$4988,5039,5044$

Gries W.

5038

Griffiths P. R.

3474,3539

Grimaldi F .

3458 
Author. Ref. No. from Part 3.

Grimbert D.

$3882, \quad 3894$

Grin' L. E.

4202

Groebner R. J .

4000

Grujic P.

$3084,3278,3280,3282$

Grujic P. V.

3160,3162

Grumberg J .

$3527,3528,3719,3884,4562$,

4563,4670

Grushetskii K. M.

4001

Grützmacher K.

$3177,3654,3989,4269,4302$, 4432,4698

Grycuk T.

3661,4002

Grynberg G.

$3090,3112,3142,3178,3262$,

3301,3302

Güdde J .

5018

Guilpin C.

3837

Guimerans Y.

4032, 4799

Gulyaev S. A.

$3179,3662,4456$

Gundersen M. A.

3457
Author. Ref. No. from Part 3.

\author{
Günter S . \\ 4800,4989 \\ Gunter W. H. \\ 4530 \\ Günther K. \\ 4504, 4505 \\ Gurevich B. M. \\ 3134,3435 \\ Gurovich V. Ts. \\ 3303 \\ Guzhva Yu. G . \\ 3105, 3106 \\ Hafez A. F. \\ 3433
}

Hahn K. H.

4983

Hahn T. D.

4902

Halenka J.

$3113,3996,4305,4308,4457$,

$4587,4699,4801,4849,4903$

Hall J. L.

3337,4184

Halpern G.

3423

Hamaguchi Y.

$3917,3918,3919,4244$

Hamme1 B. A.

4912

Hammer D.

4076

Haner D.

4842 
Author. Ref. No. from Part 3 .

Hanle W.

3475

Hänsch T. W.

3700

Hansen J. P.

4422

Haraguchi H.

4309

Harde $\mathrm{H}$.

4003

Harima H.

$3663,3754,3838,3909,4004$, $4005,4006,4588$

Haroche S.

3739

Harris M.

$3704,3839,4056,4057,4175$,

$4458,4514,4589,4654$

Harris S. E.

4983

Hart C. F.

3991

Hart R. C.

4896

Hartmann S. R.

$3170,3293,3490,3491,3524$,

$3525,3685,3715,3795,3855$,

$3874,4534,4792$.

Hasegawa $\mathrm{T}$.

4309

Hashi T.

3984

Hashimoto S .

$3180,3840,4007$
Author. Ref. No. from Part 3.

Hasselbrink E.

3822

Haubold H. J.

3304

Hauer A.

$3423,3476,3664$

Hauser M.

3568

Häusser 0 .

4997

Havey M. D.

$3790,4008,4114$

Hayes M. H.

4615

Hays G. N.

4990

Heber K. - D.

4700,5018

Hebner G. A.

4990

Heering $W$.

41.76

Hegerfeldt G. C.

3665, 3841, 4009, 4010, 4701, 4802

Heinke $\mathrm{H}$.

4011

Helbig V .

$3096,3288,3621,3642,3666$,

$3667,4012,4087,4310,4366$,

4377, 4459, 4492, 4632, 4806,

$4991,5019,5041$

Held B .

$3668,3669,3842,3843,4013$,

$4177,4178,4179,4311,4312$,

$4460,4461,4590,4702,4904$ 
Author. Ref. No. from Part 3.

Helmcke J.

3337

Heneghan S. P.

4336

Hennecart D.

3788

Henry B. I.

4014,4015

Herman P. S.

4094, 4809

Herman R. M.

4016

Hermann G.

$4651,4668,4703$

Hernandez G.

3305

Hernandez $J$.

4313

Herrero A.

4591

Hese A.

5038

Heselius S. -J.

4180

Hess $\mathrm{H}$.

4017,4181

Heuts M. J. G.

3920

Hey J. D.

$3181,3182,3477,3478,3479$,

$3670,3671,3844,4669,4794$,

$4803,4804,4905$
Author. Ref. No. from Part 3.

Hildebrandt $\mathrm{J}$.

$3480,4018,4019,4462,4592$

Hill K. W.

3264,3618

Hill R. M.

3352

Hillard G. B.

3827

Hillard M. E.

4574

Himbert $M$.

3384,3898

Himmel G.

$3306,3350,4020,4830,4834$

Hindmarsh $\mathrm{W}$. R.

3352

Hirabayashi N.

3415

Hiragi $\mathrm{Y}$.

4314

Hiraki N.

3672

Hiramatsu M.

4463

Hirano I .

3307

Hirono $\mathrm{M}$.

3845

Hirose A.

3242,3426

Hirose C.

$4578,4725,4805$ 
Hitzschke L.

$4017,4181,4333,4464,4704$, 4832,4989

Hoang-Binh D.

4593,4672

Hof D. E.

4923,5000

Hoffbeck F.

3153

Hogan D.

4200

Hohimer J . P.

$3673,3846,4182,4183,4315$

Hollander T. J.

3920

Hollander $\mathrm{T} j$.

$3183,3681,3682,4021,4073$,

$4523,4623,4624,4625$

Hollberg L.

4184

Holstein $\mathrm{T}$.

4368

Holys A.

3159

Honda $\mathrm{C}$.

4705

Hooper C. F.

3592,4187

Hooper C. F. Jr.

$3683,3776,4030,4121,4253$, 4284, 4598, 4612, 4758, 4759, $4906,4922,4999,5026$

Hooper Jr. C. F. $3849,3850,3934$
Hora H.

3481,4015

Hori H.

4909

Horst E. ter

4021

Horton R.

3264,3618

Höss P.

4316, 4501

Howell R. H.

3482

Hsieh W. - F.

4572

Huang $\mathrm{Y}$. W.

4907, 4908, 5044

Hubbard W. B.

4318

Hubeny I .

$3968,4022,4023,4465,4594$,

4778

Huber $G$.

4163

Huennekens J .

$4024,4025,4595,4970$

Hugon $M$.

$3674,3832,4173$

Hugues T. P.

3982

Hühnermann $\mathrm{H}$.

3308

Human H. G. C.

$3097,3466,3645$ 


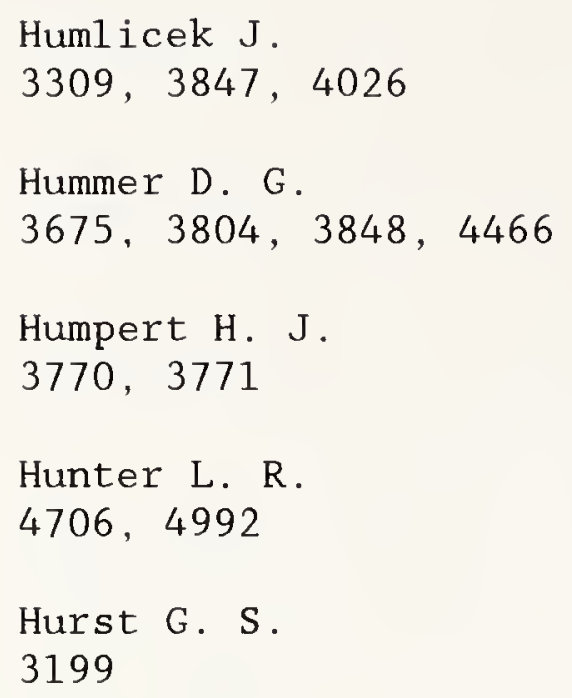

Inguscio $M$.

4272,4744

Inoue $\mathrm{Y}$.

4909

Irons F. E.

3484,3485

Irwin A. W.

3310

Ishimura $\mathrm{T}$.

4319

Ispolatov Ya. 0 .

4694,4897

Issa M. A. A.

3433

Istrefi L.

4709

Itano W. M.

3677,3851

Ito $Y$.

4319

Itoh S.

3672

Ivanov A. M.

3104

Ivanov L. N.

4188

Ivanov G. K.

3114

Iwasaki A.

3185

Iwasaki S .

3389 
Author. Ref. No. from Part 3.

Izmailov A. M.

3429

Izotova S. L.

$3311,3486,3678,4320,4321$

Jabr S. N.

3487

Jackowska I .

$4062,4063,4064$

Jackson D. A.

3679

Jackson D. J .

3330

Jacobs V. L.

$3488,3632,5026$

Jaeglé P .

$3312,3313,3852,4479,4910$

Jäger $\mathrm{H}$.

4365,4622

Jamelet G.

4910

Jamelot G .

$3312,3313,3852,4479$

Jannitti E.

$3200,3343,3355,3853$

Janssen G. C. A. M.

3680

Javanainen $\mathrm{J}$.

3941

Jayakumar R.

3680

Jeannet J . C .

$3269,3727,3890$
Author. Ref. No. from Part 3.

Jelenkovic B. M.

4966

Jelinek 0 .

4774

Jenkins D. B.

4322

Jess K.

4632,4806

Jimenez-Dominguez $\mathrm{H}$.

4807

Jitschin W.

3489

John R. W.

3304

Johnson B. C.

3545

Johnson D .

3618

Johnson P. M.

4353

Jo11y J .

4928

Jones D. W.

$4033,4189,4468,4596$

Jones L. A.

$3315,3493,3686$

Jones M. C.

4201

Jones R. N.

4034

Jongerius M. J .

$3183,3681,3682,4597$ 
Author. Ref. No. from Part 3.

Jönsson G .

4190

Joos V. E.

3568

Jortner J .

3115

Joshi N. K.

4035

Joyce R. F.

$3683,3776,4284,4598,4612$

Julien L.

4895,4963

Julienne P. S.

$3854,4191,4469,4483$

Jungmann $\mathrm{K}$.

3772,3773

Jungner $P$.

4384

Junkes J .

3082

Juric Z. D.

4783

Jüttner B.

5025

Kabiel A. M.

3684

Kachru R.

$3293,3490,3491,3524,3525$,

$3685,3715,3855,4395$

Kacprzyk M.

3492

Kadota K.

3710
Author. Ref. No. from Part 3 .

Kafrouni H.

4393

Kaftand jian P. V.

4934

Kaftand jian V. P.

$3314,3454,4235,4385,4386$, $4516,4519,4641$

Kaivola M.

3941,4323

Kaliteevskii N. I.

3186,4320

Kalkand jiev T. K.

4808

Kallne E.

$3315,3493,3686,4773$

Kalman G.

4865,4911

Kamke B .

4036

Kamke $W$.

4036

Kamla G. J .

4226

Kammermayer E.

4642

Kanorskii S. I.

$4424,4553,4666,4772$

Kantor P. Ya.

$4324,4325,4326,4327,4328$, 4329

Kantserov A. I.

$3311,3486,3678$ 
Author. Ref. No. from Part 3.

Kapicka V.

3110,4671

Karabourniotis D.

$3157,3970,4037,4038,4330$, 4331

Karabut E. K.

3494

Karamochi N.

3495

Karp A. H.

3184

Karras C.

$4038,4330,4331$

Kaspareit J .

4806

Kastner S. 0 ,

3496,5029

Kato I.

$3185,3497,3856$

Kato $\mathrm{K}$.

4192

Kato $\mathrm{T}$.

3651

Katriel J .

3857

Katulin V. A.

3619

Kauffman R. L.

$4053,4193,4203,4284,4906$

Kaulakis B. P.

3498

Kaulakys B .

3858
Author. Ref. No. from Part 3 .

Kaulakys B. P.

4194

Kawaguchi $\mathrm{H}$.

3859

Kazanskii A. K.

4667

Kazansky A. K.

4964,5030

Kazantsev S. A.

3186

Keane C. J.

4912

Kearney R. J .

$4764,4765,4766$

Kearney W. R.

4809

Keil R.

3187

Kelleher D. E.

$3096,3316,3463,3549,3687$,

$3730,4061,4355,4496,4732$,

4733,4913

Keller J. C.

3454

Kenda11 D. J. W.

4673

Kepple P. C.

$3188,3300,3476,3660,3860$,

$3931,4265,4900,4954$

Kertanguy A. de

3317

Keshavamurthy R. S.

4599 
Author. Ref. No. from Part 3.

Kesting $V$.

4701

Keto J. W.

3959,4145

Kett1itz M.

4332,4333

Key M. H.

3318,3501

Khakhaev A.D.

4124

Khan T. P.

4600

Khanin Ya. I .

4126

Khashan M. A.

3319

Khelfaoui F.

$4872,4873,4912$

Khoury R.

4677

Khvostenko G. I.

4334

Khvostov A. N.

3979

Kichenassamy S .

3861

Kidravov F. Kh.

3586

Kielkopf J .

$4862,4950,4951$

Kielkopf J. F.

$3320,3321,3499,3500,3688$, $3689,3786,3862,4039,4040$, $4335,4861,4994$
Author. Ref. No. from Part 3 .

Kilcrease D. P.

4999

Kilimann K.

$3741,4790,4914$

Kilkenny $\mathrm{J}$.

3690

Kilkenny J. D.

3501, 4053, 4193, 4203, 4345, 4416

Kim J . J .

4605

Kim S. H.

3189

Kindt $\mathrm{S}$.

3657

Kipper R.

4955

Kiriyama S. I.

3538

Kissami H.

4710

Kitade A.

4494

Kleiber P. D.

$3800,3863,4336,4601,4611$

K1 ein L.

$3314,3911,4641$

Kleinmann I.

3083

K1 im A.

3691

Klimchitskaya G. L. 4993 
Author. Ref. No. from Part 3.

Klimontovich Yu. L.

3692

Klimovskii I. I.

3251,3693

Klivadenko V. A.

4195

Kluge H. J

3459

Klyucharev A. N.

3190

Knauer J .

4824

Kneizys F. X.

3272

Knezevic V.

3214

Knollenberg R.

3689

Knudtson J. T.

4602

Koaizawa $\mathrm{H}$.

4230

Kobilarov R.

$4690,4711,4810,4915,5002$

Kobzev G. A.

$4569,4679,4875$

Kock M.

3430

Koelman J. M. V. A.

4647

Koenig M.

$4137,4214,4270,4348,4470$, $4491,4712,4713$
Author. Ref. No. from Part 3.

Kogan V. I .

4603

Kolbe G .

$3148,3625,4337$

Koledin D.

3280

Koleva I .

3780

Kolwas M.

3178

Kon'kov A. A.

3322

Kondo $\mathrm{K}$.

3984

Kondrateva V. A.

3979

Konjevic N.

3084, 3085, 3095, 3099, 3161, $3209,3210,3211,3237,3279$, $3316,3371,3460,3636,3638$, $3640,3694,3813,3932,3974$, $4041,4157,4196,4197,4338$, $4339,4340,4435,4436,4471$, $4472,4500,4522,4565,4604$, $4688,4689,4711,4722,4788$, $4810,4822,4845,4893,4915$, $4916,4917,5024,5045$

Konjevic R.

$4081,4340,4472,4689,4890$, 4891,4980

Kononov E. Ya.

3502

Koo J. Y.

4605

Koppel L. N.

3243 
Koptev Yu. V. 4133

Korving $\mathrm{J}$.

4407

Kosasa K.

3353

Koshelev K. N.

3502,4714

Kot1ikov E. I.

3789

Kotlikov E. N.

$3102,3323,3864,3979,4341$,

4473

Kötteritzsch M.

5038

Kotylev V. N.

3924,4247

Kovarskii V. A.

4628

Kozyrev A. A.

31.91

Krametz E.

4278,4429

Kramida A. E.

3676

Krause D. Jr.

4706,4992

Krause L.

3933,4523

Kravchenko V. F.

3494

Krebs D. J .

3865,3866
Kretzas D.

3192

Kreye W. C.

$3867,4042,4994$

Krikorian R.

3861

Krishnamurty G.

4831,5040

Kroll R.

4825

Kroop V.

3503,3606

Krsl janin V.

$4290,4399,4401,4437,4811$,

$4812,4813,4814$

Krueger D. A.

4918

Kruger R. A.

3645

Krylov P. S .

4403

Kryszewski S.

4995

Kryukov N. A.

3695,4497

Kuchinskii V. V.

$3129,3130,3244,3285,3429$

Kuchta E.

4918

Kudrya V. P.

4043

Kudryavtsev A. A.

3868 
Author. Ref. No. from Part 3 .

Küh1 T.

3459,4163

Kuik P.

4523

Kulander K. C.

4044

Kulkarni I. V.

4831

Kulyasov V. N.

$3924,4128,4398,4539,4646$

Kunasz P.

3787

Kunski R .

3921,3922

Kunze H. J.

$3421,3467,3480,3696,4066$, 4695,4794

Kunze H. - J .

$4554,4617,4669,4905,5005$

Kuo C. - Y.

3959

Kuramochi N.

$3118,3193,3324$

Kurbatov A. L.

4646

Kurilenkov Yu. K.

$3504,3697,4868$

Kurochka L. N.

3086,3325

Kusch H. J.

$3216,3386,3387,3400,3869$

Kutznetsov M. N.

4198
Author. Ref. No. from Part 3.

Kuznetsov S. V.

4474

Labastie P.

3870

Labat J .

$3084,3098,4630,4736,4737$,

4738, 4741, 4889, 4890, 4891,

4892, 4919, 4933, 4979, 4980,

$4981,4982,5011,5033,5034$,

5035

Labat J. M.

4996

Labat 0 .

$3735,4687,4919,4979,4996$

Labuhn F .

3155

Labuz S.

$4362,4489,4730$

Labzovskii L. N.

4045

Lado $\mathrm{F}$.

4475,4606

Lakicevic I. S .

$3212,3326,3379,3380,3553$,

$3698,3699,3735,3736,3737$,

$3871,3893,4046,4047,4048$,

$4049,4054,4083,4084,4223$,

$4224,4342,4372$

Lakshmi P. A.

4544

Laloë F.

3369

Lam J. F . 3907 
Lambert D .

$3505,4050,4343$

Laming J . M.

4607

Lancaster H. L.

4735

Landen O. L.

$4344,4345,4346$

Landers F. J .

4501

Lane A. M.

4815

Lane R. G.

4608

Lange $\mathrm{W} . \mathrm{K}$. H.

3545

Lanz $\mathrm{T}$.

4715

Laporte $\mathrm{P}$.

$3327,3328,4051$

Larenz R. W.

4052

Larkins P. L .

$4199,4347,4716$

Larour J .

4381

Larour J. B.

4866

Larson B.

4997

Larson G. F. 3329
Lasnitschka G.

4651,4668

Lassale J .

3647

Latipov R. Z.

4508,4633

Latush E. L.

4133

Lau A. M. F.

4476,4609

Lavi S .

4241

Law J .

4200,4201

Lawler J. E.

$3297,3330,3700$

Lawrenz J .

4011,4754

Lax B.

3360,3541

Lazarenko A. V.

3190

Lazarus E.

3423

Lazovskaya V. R. 3331

Le Gall P.

4166

Le Gouët J. L.

3194

Le Toulouzan J. N. 3701 
Author. Ref. No. from Part 3.

Lebedev V. S.

4610

Lebedeva $V$. V.

4202

Leboucher E.

$3506,3528,3702,3719,3884$, $4348,4562,4563,4670$

Lebowitz J. L.

$4031,4127,4186,4318,4949$

Lebrun J. L.

$4225,4722,4920$

Leclair J.

3388

Lecler D.

3788

Lecourt A.

3458

Lednev M. G.

4852

Lee C. M.

3423

Lee R. W.

$3268,3332,3333,3334,3335$,

$3336,3501,3507,3690,3703$,

$3799,3872,3873,3957,4053$, $4187,4193,4203,4204,4284$, $4317,4344,4345,4349,4350$, 4717,4912

Lee S. A.

3337,4323

Leegwater J.A.

4625

Leeuw A. de

4021
Author. Ref. No. from Part 3 .

Lekhto G. F.

4320,4321

Lemaire J. L.

$4351,4477,4478$

Lemaire $\mathrm{P}$.

4479,4910

Lemoine $\mathrm{D}$.

4718

Lempert $\mathrm{W}$. R.

4574

Leneva A. E.

3091

Lennuier R.

3890

Lesage A.

$3214,3522,3753,3879,4054$, $4086,4225,4358,4722,4816$, 4920,5010

Letzring $\mathrm{S}$.

3423

Leung $\mathrm{K}$. P. 3715,3874

Levesque D . 4127,4949

Levin L. A. 3115

Levine M. A.

3198,3563

Levinson C .

4190

Levoshkin A. V.

4512,4513 
Levy B .

$3271,4430,4676,4932,5016$

Lewis E. L.

$3117,3144,3449,3508,3656$,

$3704,3826,4055,4056,4057$,

$4175,4361,4383,4458,4485$,

$4514,4589,4614,4654,4729$

Lewis $\mathrm{J} . \mathrm{T}$.

4445

Lewis L. L.

3677,3851

Leycuras $\mathrm{Y}$.

4352

Li E.

4139

Li L .

4353

Li Q. $-R$

4760

Li Y. H.

4918

Liao P. F.

$3258,3338,3509$

Liberman $\mathrm{S}$.

4058

Lilenfeld H. V.

3339

Lin C. L.

3340

Lin $\mathrm{J}$.

4855

Lindberg $M$.

4384
Lindblom $P$.

4180

Lindsay A. C .

4817, 4998

Lindsay J. M.

3347

Linnebur E. J.

3476

Lins G. A. W.

3421

Liran J .

3115,4241

Lisicki E.

$3140,3341,3510,3511,3512$,

$3616,3617,3705,3875,3876$,

$4059,4205,4276,4354,4551$,

$4570,4571,4692,4789$

Lisitsa V. S.

3091, 3342, 3602, 4603, 4818, 4863

List E.

3513

Little R.

4577

Liu J. R.

4416

Liu W. K.

3514

Ljublin B. V.

$4060,4719,4851$

Llewellyn E. J.

4673

Lobb W. S.

4720 
Author. Ref. No. from Part 3.

Locquet $\mathrm{J}$. J .

3701

Lokner V.

3515,4113

Lombardi G. G.

4061,4355

Lorenzen C. - J .

4105

Loudon R.

3784

Louis-Jacquet $M$.

4050,4343

Lovett R. J .

$3116,3516,4482,4560,4677$, 4678

Lowe R. P.

3351

Lozingot $\mathrm{J}$.

$3391,3465,3559,3560,3644$

Luiten 0. J .

4647

Luizova L. A.

3706

Lukaszewski M.

$4062,4063,4064$

Lunney J . G.

3318,3501

Lwin N.

$3117,3195,3839$

Lyublin B. V.

$3952,4418,4819$

Lyyra A. M.

4336,4611
Author. Ref. No. from Part 3.

MacGowan D.

4031,4318

Mackinnon D. J .

4322

Made j J .

$3996,4305,4587,4820,4921$

Maeda M.

4705

Maiorov S. A.

3619,4721

Majdi $Y$.

4144

Makdisi Y.

4869

Makhrov V. A.

4256

Maldelbaum D. 3900

Malesevic M.

4787

Malikov R. F. 3707

Malnoult $P$.

4712

Malvern A.

3156

Malvern A. R. 3517.

Malvezzi A. M. 3200,3343

Malyshev V. A. 3707 
Author. Ref. No. from Part 3.

Malyugin A. V.

3101

Manassah J. T.

4792

Mancini R. C.

$4612,4906,4922,4999,5026$

Mande1 baum D .

$3964,4032,4799$

Mangeot $B$.

3837

Mann C. K.

4821

Manners J.

$4161,4162,4480$

Manning $\mathrm{T}$. J .

4923,5000

Manola S.

$4086,4225,4722$

Maquet $\mathrm{A}$.

3877,3942

Mar S.

$3344,3990,4242,4313,4481$,

$4797,4926,5007,5008$

Marangos J . P.

4136,4723

Marasinghe P. A. B.

4482

Marchenko V. S.

4610,4724

Margerie J .

3585,3926

Marié E.

3232,3757
Author. Ref. No. from Part 3.

Marinkovic $M$.

5006

Markman D. L.

3995

Marmolino C.

4584

Marsha11 T. C.

3472

Martin G. A.

3172

Martin P.

3708,3732

Maruyama $Y$.

3353

Masaki T.

4725,4805

Maslennikova L. B.

3086

Maslov V. A.

4164

Masnou-Seeuws F .

$3364,3633,3634,3709,3971$

Matera M.

4965,5037

Mathys $\mathrm{G}$.

$4065,4206,4207,4208,4356$, 4357,4924

Matisov B. G.

$3104,3105,3106,3253,3254$, 3995

Matsuda I.

$3118,3193,3324,3495$ 
Author, Ref. No. from Part 3 .

Matsunaga $\mathrm{K}$.

3710

Matsuoka $\mathrm{H}$.

$4131,4132,4266,4542,4543$

Matthews D. L.

$3482,3703,4053,4193,4203$

Matthias E.

$3657,4700,5018$

Mattioli M.

3441,3620

Matveev V. S.

3711

Maulat C.

4298

Maurmann S.

4066,4695

May R. D.

4726

Mayer G.

3518

Mazighi R.

4422

Mazing M. A

3519

Mazure A.

$3196,3345,3520,3653,3878$, 4102,4209

Mazzoni M.

5037

McCartan D. G.

$3117,3195,3839,4720$

McClain S. C.

4595
Author. Ref. No. from Part 3.

Mc Cown A.

3717

McCrory $\mathrm{R}$.

3423

McGrory R. L.

3592

McDade I. C.

4673

McDowell C. A.

3542

McFarlane R. A.

3907

McGinley J. V. M.

3627,3807

McHugh D.

4175

McHugh D. R.

$4458,4514,4589,4654$

McLaren J. W.

4210

McMahon D. R. A.

3712

McNeil J . R.

3346

McNeill D. H.

4067

Measures R. M.

4148, 4559

Meckler A.

4695

Meier R. R.

3713 
Author. Ref. No. from Part 3.

Meijer H. A. J.

3920

Meise1 G.

3489

Me jaski-Tone jc A.

3087

Melik-Pashaev D. A.

4769

Mendez A.

3964

Menzel N.

3308

Mergault P.

3758

Mermet J. M.

$3605,3714,4210$

Metcalf $\mathrm{H}$.

3910

Metzke E.

4017,4181

Meyer $W$.

4213

Meystre P.

4367

Michelis C. de

3620

Mies F. H.

$4191,4469,4483$

Mihajlov A. A.

$4566,4783,4784$

Mihalas D.

4564
Author. Ref. No. from Part 3 .

Mi jatovic Z.

$4613,4626,4690,5001,5002$

Mi jovic S.

4822

Mikhalevskii V. S.

3494

Miklaszewski W.

4874

Miles R. B.

3781

Miller B. J.

3172

Miller E. A.

4638

Miller M. H.

$3347,3348,3521,3522,3753$,

$3879,4086,4358,4816$

Miller T. A.

$3360,3541,5036$

Millie $\mathrm{Ph}$.

3271

Milone A. A. E.

4727

Milone L. A.

4727

Milonni P. W.

4823

Milosavl jevic M.

4687,4787

Milosevic S.

$3796,3822,3925,4109$

Minaev P. V.

3693 
Author. Ref. No. from Part 3.

Minguzzi $\mathrm{P}$.

$4359,4427,4484$

Miron E.

4241

Mironov A. V.

4728

Mirza M. Y.

3146,3798

Mishin I. V.

4925

Misyunas A. A.

$3119,3120,3121$

Mitchell K. B.

3476

Mitev V. M.

3349

Miyake S.

$4131,4132,4266,4542,4543$

Mizui J.

3651

Mizuike A.

3859

Mizuta $\mathrm{Y}$.

3523

Mnatsakanyan A. Kh.

3597,4360

Möbius E.

3350

Moffatt D. J.

4147

Mokhov A. V.

4324
Author. Ref. No. from Part 3.

Molander $\mathrm{W}$.

4750

Mon ju M.

3754

Montaser A.

3880,4776

Monteiro T. S.

$4361,4383,4485,4614,4729$

Moos H. W.

4664

Moreno $\mathrm{F}$.

4211

Moreno J. C.

$4824,4901,4908,4988,5039$

Moreno J. M.

3344

Morgan F. J.

3351

Morgan W. L.

4350

Morozov A. V. 3251,3693

Morris C. E.

4615

Moshary F.

4534

Mossberg $\mathrm{T}$.

3293

Mossberg T. W.

$3170,3490,3491,3524,3525$, $3685,3715,3795,3855,3874$

Moussounda P. S.

4486,4616 
Movre $\mathrm{M}$.

$3190,3233,3356,3515,3526$, $3583,3584,3755, .3796,3797$, 4140

Movsesyan M. E.

4487

Moynault J. M.

3537

Mueller M. M.

3476

Mukai yama $\mathrm{T}$.

3423

Mukame1 S .

$3738,3881,3882,3894$

Mullamphy D. F. T.

5003

Muller C.

4212

Müller W.

4213

Mul1igan F. J.

4488

Mungo A. J.

3759

Muradov V. G.

3241

Murakawa K.

3094,$3197 ; 4068$

Muraoka $\mathrm{K}$.

4705

Murthy S.

4706
Musielok J .

$3113,3122,3716,3937,4255$, $4457,4554,4617$

Musiol K.

$4033,4362,4489,4730$

Mwana Umbella I. S. K. 4220

Myers B. R. 3198,3563

Myint $\mathrm{H}$.

3352

N'Dollo M.

4443,4618

Nadkhin A. I. 3958,4840

Naka jima S. 3353

Naka jima T.

4192

Nakamura K.

3672

Nakazawa T.

3845

Nam C. H.

4619

Namioka T.

5043

Naqvi A. S.

$4363,4364,4490$

Narumi $\mathrm{H}$.

$3594,3778,4123$

Nash D. L.

3759 
Nasr F. I .

3684

Naveedullah K.

$4363,4364,4490,4620$

Nayfeh M. H.

$3199,3717,3827$

Nee T. -J. A.

4621

Nefedev L. A.

3883

Neger $T$.

4365,4622

Nesterov M.

3140

Neufeld C. R.

3354

Neumann D. K.

4069

Neureiter C.

4757

Nez F.

4963

Nguyen D. H.

3413

\section{Nguyen Hoe}

$3506,3527,3528,3718,3719$, $3884,4137,4214,4270,4348$, $4470,4491,4546,4562,4563$, $4670,4712,4713,4867$

Nick K. P.

$3621,3667,4012,4366$

Nick K. -P.

$4377,4459,4492$
Nickolov J. B.

4808

Nicol J. L.

$4817,4937,4998$

Nicolosi P.

$3200,3343,3355,3720,3853$, 4095

Niemax $\mathrm{K}$.

$3356,3418,3419,3529,3885$, $3929,3930,4011,4036,4070$, $4105,4116,4231,4232,4245$, 4754

Nienhuis G.

$3201,3202,3230,3270,3357$, $3530,3531,3532,3721,3886$, $3903,4071,4072,4228,4267$, $4378,4509,4995$

Niepraschk R.

4181

Nieuwesteeg K. J.

$4073,4623,4624,4625,4731$

Nightingale M. P. S .

4074

Nigmatullin R. R.

5004

Nikitin V. V.

3783

Nikoghossian A.

3861

Ninoyan Zh. 0 .

4215

Niple E.

3358

Nishimura Y.

4299 
Noll R. J .

3533

Nollez G.

$3196,3345,3520,3653,3828$,

$3878,3993,4102,4209$

Nordgren $\mathrm{J}$.

4135

Norkunas V. K.

3119

North P.

4825

Nosach V. Yu.

3619

Nota M.

4969

Novikov V. G.

4568

Nowak S .

4826

Nubbemeyer $\mathrm{H}$.

3534

Nurmatov E. M.

4467

Nussenzveig H. M.

3158

Nyman E. M.

4180

O'Brien D. P.

4367

$0^{\prime}$ Callaghan M. J .

$4368,4827,4828$

O'Connell R. F.

4445
O'Leary S. V.

3823

O'Mara B. J.

3203, 4493, 4953

O'Neill J. A.

3535,3536

Obbarius H. U.

3245

Occelli R.

3537

Oda $\mathrm{T}$.

3538

Odintsov A. I.

4202

Ohman Y.

4075

Okada K.

4494.

Okasaka R.

3123 .

Oks E. A.

$31.25,3985,3987,4216,4300$,

$4495,4694,4762,4793,5005$

Olesik J. W.

4829

O1son M. L.

3474,3539

Omenetto $\mathrm{N}$.

3540

Omont A.

3089,3092

Oreg J.

4241 
Author. Ref. No. from Part 3.

Orihara S.

3180

Orlov A. V.

3923

Oshida T.

3389

Oshio Y.

3859

Osipova E. A.

4146

Osterheld A. L.

4912

Osterhold M.

4830,4834

Ostryakov V. M.

3434

Otieno A. V

3204

Ottersbach G.

4052

Oura N.

3324,3495

Ovakimyan T. 0 .

4487

Ovsiannikov V. D.

3722

Oxenius $\mathrm{J}$.

$3968,4022,4023,4594$

Oża D. H.

$4496,4732,4733,4734,4831$, 4913,4942

Padmanabhan S.

5040
Author. Ref. No. from Part 3.

$\mathrm{Pal}$ R.

$3205,3359,4076$

Palmer B. A.

$3983,4297,4923,5000$

Palomares $\mathrm{F}$.

4683

Pan Y. L.

3243

Pankonin V.

4233

Pankratov P. M.

$4569,4679,4875$

Panock R.

3360,3541

Pantelic D.

4822

Papchenko A. A.

4666,4772

Pargamanik L. E.

$3206,3723,3887,3888,3889$, 4217

Park C.

3374

Park H. J.

4595

Parsons M. L.

3116,3516

Parthasarathi V.

3542

Pascale J.

3093,4402

Patch R. W.

3361 
Author. Ref. No. from Part 3.

Patil S. H.

3724

Paul E.

3275,3362

Paul in $\mathrm{P}$.

3922

Pavlov E.

3250

Pavlov L. I.

3349

Pavlov $M$.

$4613,4626,4627,5001,5002$

Pavlov S. V.

3285

Pavlov Yu. V.

4993

Pavlovic M. S.

5006

Pavlovic N. Z.

5006

Pavlovskaya N. A.

4853, 4946, 4947

Payne G. L.

3544

Payne M. G. .

$3199,3363,4575,4896$

Peach G.

$3725,3726,4218,4540,4886$, 5003

Peacock N. J.

3124,3222

Pease D. C.

3950,4077
Author. Ref. No. from Part 3.

Peck S. K.

4561

Pelayo J.

3107

Pellissier J. L.

3458

Penkin N. P.

$3425,3695,4324,4325,4326$,

$4327,4328,4411,4497$

Perchuk 0. V.

4341, 4473

Peregudov G. V.

3619,3676

Pere1'man N. F.

3543,4628

Pérez C.

$4926,5007,5008$

Perez J. D.

3544

Perrin D.

3727,3890

Perrot F.

$4369,4433,4927$

Perry B.

3423

Pert G. J.

3455,3456

Pestov E. G.

4219

Petite G.

3545

Petrashen A. G.

3891 
Author. Ref. No. from Part 3.

Petrov V. P.

4808

Petrov. A. L.

3619

Petrukhin E. A.

3595

Pettersson L.

4135

Petzold H. C.

3207

Pfenning $\mathrm{H}$.

4220

Phelps A. V.

3824

Philippe M.

3364

Phillips H. A.

4735

Phillips W. D.

3767,3768

Picart $J$.

$4246,4593,4672$

Pichler G.

$3208,3233,3356,3381,3526$, $3583,3584,3728,3761,3796$, $3822,3925,4109,4110,4596$

Pickett H. M.

3546,3547

Piel A.

$3350,3365,3366,3548,3729$, $4078,4079,4221,4374,4412$, 4948

Pignolet P.

$3367,3820,3980,4460, .4461$, $4498,4590,4702$
Author. Ref. No. from Part 3 .

Pikuz S. A.

3265,3619

Pilon P. J.

3368

Pinard $J$.

4058

Pinard $\mathrm{M}$.

3369,3892

Pinder A. C.

3517

Pinnekamp F.

$3365,3370,3548$

Pipkin F. M.

3412

Pires A.

3533

Pittman $\mathrm{T}$.

4339

Pittman T. L.

$3549,3730,4080,4471,4499$,

4500,4604

Plain A.

4928

Platisa M.

$3085,3209,3210,3211,3371$,

$4081,4340,4631,4687,4689$,

$4736,4737,4738,4740,4889$,

$4890,4891,4933,4979,4981$,

$5011,5033,5034$

P1ayford C. St. Q.

$3148,3443,3625$

P1omdeur P.

3828,3993 
P1on J .

4963

Poise1 H.

4501

Pokrzywka B.

4362,4730

Pollock E. L.

4370,4517

Polrzywka B.

4489

Polushkin I. N.

4126

Ponomarev Ya. I.

4286

Popov A. K.

3550

Popov K. G.

$3372,3373,3551$

Popov V. I.

4261

Popovic L.

4980

Popovic M.

$3210,3371,4822$

Popovic M. M.

4566, 4756, 4785

Popovic M. V.

$3211,4711,4810$

Popovic S.

3095

Popovics C.

4134
Poquerusse A.

$4562,4563,4670$

Pospieszny J .

4870

Post H. A.

4502, 4503

Pouilly B.

4718,5009

Poulsen 0 .

4323

Prakash S. G.

3374

Pratesi R.

5037

Pratt R. H.

5014

Preobrazhenskii N. G.

$3375,3376,3377,3552,4674$

Preppernau B. L.

5036

Price D. C.

3731

Prigent $\mathrm{P}$.

4294

Prilipko V. K.

3596

Pritchard D. E.

$3588,3767,3768,4082,4250$

Privalov V. E.

4403

Proctor T. R.

3239 
Author. Ref. No. from Part 3.

Profeti S.

4484

Protasevich E. T.

4680

Prud'homme M.

4660

Prunelé E. de

3674

Puerta J .

3708,3732

Puetter R. C.

3733

Pujol G.

3378

Purce11 S. T.

4222

Puric J.

$3098,3212,3213,3214,3326$,

$3379,3380,3522,3553,3698$,

$3699,3734,3735,3736,3737$,

$3871,3893,4047,4048,4049$,

$4054,4083,4084,4223,4224$,

$4371,4372,4629,4630,4631$,

$4687,4736,4737,4738,4739$,

$4740,4741,4787,4889,4890$,

4891, 4919, 4933, 4979, 4996,

$5010,5011,5034$

Put1itz G. zu

4373

Qian J .

4653

Quattropani A.

3944

Rabin Y.

$3738,3894,3895$
Author. Ref. No. from Part 3 .

Rabinovitch A.

3649

Rabitz H.

3607,4752

Radmore P. M.

3650

Radovanov S. B.

4966

Radtke R.

$4332,4333,4504,4505$

Raggett D. St. J .

3746

Raimond J. M.

3739

Raja Sekhar B. N.

5040

Rajan M. S.

4085

Ra jaRao P. M.

5040

Rakotoarijimy D.

3994

Rakowitz J .

3250

Ramadan A. G.

3945

Ramette J.

$3163,3164,3283,3284,3620$

Rang L. Q.

3740,4506

Ranson P.

$3468,4486,4616$ 
Author. Ref. No. from Part 3 .

Rao B. K.

3896

Rao P. M. R.

4831

Rarig P. L.

3577

Rathore B. A.

4048, 4054, 4083, 4223, 4224, 4629

Ratkevich V. K.

4418

Rautian S. G.

3554,3897

Raymer M. G.

3381

Raymond T. D.

3959,4145

Razumov V. A.

3483

Rebane T. K.

3891

Rebane V. N.

$3215,3382,3383,3891$

Rebentrost $F$.

3895,4044

Rebhan U.

4118

Rebolledo M. A.

4171

Redko T. P.

3695,4497

Rees D. E.

4749
Author. Ref. No. from Part 3.

Reibold R.

$3555,3665,3841,4009,4010$

Rethmatulla M. I.

4490

Reyna Almandos $\mathrm{J}$.

4682,4781

Reynaud S.

$3153,3384,3898$

Ricard A.

4547

Richards A. G.

3336

Richards L. M.

3243

Richards M. A.

4615

Richardson M. C.

4284, 4906

Richardson R. J .

3339

Richou J.

$3753,4086,4225,4722,4920$

Richter H.

$3366,4078,4079,4374$

Ridard J .

3271

Riis E.

4323

Rish O. M.

3186

Rizzo J.

3423 
Author. Ref. No. from Part 3.

Robbe J. M.

4718

Robert D.

3143

Roberti G.

4584

Röche-Hansen J .

4632

Rodin N. V.

4646

Roesler F. L.

4042

Rogers F. J.

3957,4375

Rogers G. L.

5012

Rogoff G. L.

3556

Rohatgi V. K.

4035

Rohde V.

4806

Röhe-Hansen J .

4087, 5041

Roig J .

3647

Roig R. A.

3348

Romanenko E. V.

3794

Romanov G. S .

3385
Author. Ref. No. from Part 3.

Ron A.

4229,4390

Röndigs $G$.

$3216,3386,3387$

Roney $W$.

3618

Röpke G.

$3741,4464,4704,4832,4989$

Rosado R. J .

3388

Rosenbluh M.

3360,3541

Rosenfeld Y.

4833

Rosinski K.

4746

Rostas F.

$3401,3633,3634,3971,4351$, 4477,4478

Rottler L.

4000

Roueff E.

$3401,3748,3899,4088$

Rous J .

4381

Rousse1-Dupré D.

4089

Rout R. K.

4831

Rovera G.

3613

Rowan W. L.

4421 
Royer A.

$3217,3557,4090,4091$

Rozsa K.

4735

Rozsnyai B. F .

3218, 4092, 4581

Rudavets A. G.

3554

Ruffert $M$.

4834

Rukavina $J$.

3584

Rumsby P. T.

3318

Russo A. L.

3145

Ruzov V. P.

$3372,3373,3551$

Ryabtsev A. N.

4507

Rybko L. B .

3325

Safinya K. A.

3558,3652

Safronova U. I.

3502

Sahal-Bréchot S.

$3637,3815,3816,3817,3973$, $3976,3977,3978,4156,4158$, $4287,4291,4292,4438,4567$, $4786,4881,4882,4883,4885$, $4887,4971,4973,4974,4975$, $4976,4977,4978,5013,5031$, 5032
Sakharov V. B.

3176

Sakurai T.

3389,4909

Salakhov M. Kh.

$3646,3742,4093,4376,4508$, $4576,4579,4633,4743,4835$, 5004

Salganik Yu. A.

3372

Salour M. M.

3545

Salpeter E. W. 3082

Salter J.M.

3704

Salzmann D.

5014

Sanchez A.

$3900,3964,4032,4634,4799$

Sanchez-Soto L. L.

4767,4768

Sandeman R. J.

3246

Sandle W.

4639

Sandner $\mathrm{W}$.

3652

Sando K. M.

$3464,4094,4296,4336,4601$,

$4611,4742,4809$

Santi D .

4095 
Author. Ref. No. from Part 3.

Sapondzhyan S. 0 .

4215

Sarandaev E. V.

$3646,3742,4376,4508,4633$,

4743,4835

Sarandayev E. V.

4093

Saraswathy P.

4831

Sargent III M.

4428

Sarkisyan G. S .

4215

Sasso A.

4744

Sato $M$.

3219

Sato Y.

$5020,5021,5022,5043$

Sattarov I.

3220

Sautenkov V. V.

3783

Sauthoff N.

3618

Sauthoff N. R.

3264

Savard J. Y.

3921

Savary $P$.

3701

Savinov S. Yu.

4096
Author. Ref. No. from Part 3.

Savukynas A. J.

3390

Savushkin A. F .

3595

Saxena R.

3901

Sayer B .

$3391,3465,3559,3560,3644$,

$3751,3762,3763,3832,3902$,

$4173,4402,4441,4442$

Schade W.

4377

Schäfer J . H.

4278,4429

Schäfer R.

4103,4391

Scharmann A.

3475,4651

Schatzman E.

3392

Schawlow A. L.

3297,3330

Schearer L. D.

3865,3866

Scheeline A.

4226

Scheibner $\mathrm{H}$.

4138

Schilling $M$.

4115

Schle jen J.

4407,4635 
Author. Ref. No. from Part 3 .

Schlessinger L.

3743

Schlüter $\mathrm{H}$.

4830,4834

Schmidt D.

3657

Schöning $\mathrm{T}$.

4836,4837

Schram D. C.

3388,4826

Schröder K.

3869

Schuessler H. A.

3459

Schüller D.

4278

Schuller F.

$3202,3270,3357,3532,3903$,

$4227,4228,4378,4509$

Schulz-Gulde E.

3245

Schulze H.

4802

Schumann L. W.

3590

Schwamb D. H.

3393,3561

Scoarnec L.

3157

Scofield J.

3703

Scott A. M.

3455,3456
Author. Ref. No. from Part 3.

Scott R. H

3097

Seaton M. J

$4636,4745,4838,4929$

Sebyakin Yu. N.

$4285,4286,4681,4854$

Sedel'nikov A. I .

$3376,3377,3552$

Sedelnikov A. I

3375

Seely J. F.

4619

Segal D

4839

Segre E. R. A.

3765

Seidel J

$3394,3562,3744,3904,4097$,

$4379,4510,4511,4698$

Seifert T

3741,4464

Selezneva L. A.

3251

Sem M. F .

4133

Semin P. S.

$3291,3646,3742$

Senkov N. V.

3783

Severino $G$.

4584,4952

Shabaev V. M.

5015 
Author. Ref. No. from Part 3.

Shabanova L. N.

$3425,3936,4324,4325,4326$, $4327,4328,4329,4411,4512$, 4513,4930

Shalaev V. M.

3550

Shalagin A. M.

3554

Shalitin D.

4229,4390

Shalom A.

3690

Shannon I.

$4175,4458,4514,4589,4654$

Shapiro D. A.

3398,3897

Shaver $\mathrm{P}$. A.

3395

Shaw J. H.

3340,3358

Shaw R. S.

3563

Shcherbakova N. K.

5004

Shchipakov V...A.

4863

She C. Y.

4918

Shea R. F.

4069

Shefer R. E.

3396
Author. Ref. No. from Part 3.

Sheremeteva T. A.

3905

Shevel'ko A. P.

3519

Shikov V. K.

4360

Shilov K. A.

3619

Shimizu M.

3123

Shimizu T.

3185

Shimoda K.

3408

Shimokoshi K.

4034

Shindo $\mathrm{H}$.

3397,3564

Shiomi N.

3118

Shirai $\mathrm{H}$.

4230

Shmavonyan S. V.

4487

Shoaeb A. M.

3684

Sholin G. V.

$3431,3662,4456,4603$

Shubin M. V.

4646

Shuker R.

4582 
Author. Ref. No. from Part 3 .

Shul'ga A. G.

4202

Shyam A.

4831

Siddiqui A.

4931

Sidel'nikov Yu. V.

3502

Siegel A.

3700

Siegling $\mathrm{F}$.

4231,4232

Sienkiewicz J.

$4151,4152,4380$

Silver $\mathrm{E}$.

3618

Silver J. D.

4607

Simard P. A.

3906

Simonneau E.

4022, 4023

Singer S. J.

4483

Singh S.

4763

Sirko L.

4746

Sivkov V. N.

3372

Skarsgard H. M.

3242,3426
Author. Ref. No. from Part 3.

Skobelev I. Yu.

3619

Skowronek $M$.

$4381,4649,4650,4755,4756$

Skrebov V. N.

3868

Skupsky S

$3423,3565,3592$

Slemzin V. A.

3519

Slivinsky V. W.

3243

Slupek J .

4221

Smirnov G. I.

3398,3897

Smirnov G. T.

4233,4382

Smirnov V. G.

4418

Smith C. C.

3221,3222

Smith E. W.

$3092,3154,3446,3745,3805$,

$4234,4235,4236,4237,4385$

Smith G.

$3535,3536,3746,4383,4637$, 4747

Smith S. R.

3561

Smulders P. J. M.

4515 
Snow W. L.

3168

Sobel'man I. I.

$3410,3747,4424,4666,4772$

Sokolov A. S.

3399

Sokolov I. M.

$3434,3793,3946,3947$

Solin 0 .

4180

Solnyshkov D. A.

4418

Soltwisch H.

3400

Solyanikova V. A.

3223

Sonobe 0 .

5020,5043

Sorochenko R. L.

4233

Sorokin V. N.

$4424,4666,4772$

Sotnichenko S. A.

3958,4840

Sotome H.

5021,5022

Soures J.

3423

Soures J. M.

3592

Sowa L.

3306,4020
Spanke R.

$4332,4333,4505$

Spektorov V. L.

3303

Spiegelmann F.

4098,4486

Spielfiedel A.

$3401,3588,3748,3767,3768$, $3899,4088,4842,4932,5016$

Squire $\mathrm{W}$.

3566

Sreckovic A.

$4630,4631,4687,4736,4737$, $4738,4739,4740,4741,4787$, $4889,4890,4891,4892,4919$, 4933, 4979, 4980, 4981, 4982, $4996,5011,5033,5034,5035$

Srivastava H. M.

4638

Stacey D. N.

$3224,3247,3517,4099,4817$, 4998

Stahlberg B.

3567,4384

Stamenov K. V.

3349

Stamm R.

$3402,3766,3904,4100,4234$, $4235,4236,4237,4238,4385$, $4386,4516,4517,4519,4558$, $4641,4675,4872,4873,4912$, 4934

Stanton A. C. 4101

Starostin A. N. 4256,4863 
Stastny $\mathrm{F}$.

$4277,4556,4671$

Steckner M.

4293

Steel D.

3423

Stee1 D. G.

3907

Stefanel A.

4658

Stefanov B.

3923

Stefanovic I.

5024

Stehlé C.

4102, 4239, 4240, 4387, 4388,

$4389,4518,4748,4841,4935$,

4936,5017

Stein J.

$4229,4390,5014$

Steinfeld J. I.

3648

Steinwande1 J.

3568

Stepanov K. I .

3385

Stephenson G.

3650

Stewart B.

4250

Stodiek W.

3264,3618
Stoicheff B. P.

$3403,3569,3749,4642,4643$

Stoner R.

4561

Stoof H. T. C.

4647,5042

Stormberg H. P. 3570,4103

Stormberg H. - P. 4391

Stotskii G. I. 3225

Stout II R.E. 4204

Strauss $M$.

4241

Streater A.

$4420,4639,4749,4750$

Streeter T. J.

3955

Stroke H. H.

3384

Struk I. I.

$4424,4666,4772$

Strumia F.

3613,4272

Stul'pinene N. A.

$3119,3120,3121$

Stulpinene $\mathrm{N}$.

3571

Stwalley W. C

$3238,3239,3240,3777,4336$ 
Su J. F.

4937

Subtil J. L.

4051

Suckewer S.

4619

Suemitsu H.

4938

Sugie $\mathrm{T}$.

3404

Sukhin S. A .

3692

Sullivan D. E.

3988,4169

Sultan G.

4547

Sulzmann K. G. P.

4104

Sun J. N. - P .

3474

Sun J . - Q .

4939,5018

Sung T. W.

4706

Supronowicz J.

3933

Suter L. J.

4912

Sutton D. G.

4602

Sutton $\mathrm{K}$.

3226
Suvorov A. E.

4640,4674

Svanberg S .

4190

Syrkin M. I .

3385,3750

Szebesta D.

4654

Szudy J .

$3227,3228,3229,3260,3341$,

$3438,3511,3512,3572,3615$,

$3705,3751,3762,3763,3832$,

$3875,3876,3908,4059,4173$,

$4205,4276,4354,4423,4532$,

$4551,4570,4571,4652,4870$,

4961,4962

Tabei K.

4230

Tabisz G. C.

4984

Tachibana K.

$3663,3754,3838,3909,4004$, $4005,4006,4588$

Taiqian D.

3910

Takemoto $\mathrm{Y}$.

4938

Taleb A.

4058

Talin B.

$3314,3745,3911,4235,4236$, $4238,4385,4386,4516,4517$, $4519,4558,4641,4675,4872$, $4873,4912,4934$

Tallents G. J.

$3573,3912,4773$ 
Author. Ref. No. from Part 3 .

Tan T. H.

3476

Tanaka K.

3389

Tang K. T.

4940

Tanigawa $M$.

3984

Tanner C. E.

4751

Taran M. D.

4256,4863

Tarrini 0 .

3962,4427

Taylor P. R.

4520

Tchang-Brillet W. -Ü. L.

4842

Tenenbaum $\mathrm{J}$.

4241

Terpugova N. S.

3191

Terray L.

4348,4470

Terry J. L.

4664

Terskikh A. 0 .

4856

Terzic M.

4627

Tetu M.

$3413,3921,3922$
Author. Ref. No. from Part 3 .

Thieberger R.

3649

Thiessen D.

4997

Thoma P.

3137

Thomann P.

3574

Thompson D. C .

$3749,4642,4643$

Thompson R. C .

$3224,3247,3517,3913,4099$

Thompson R. E.

3577

Thomsen C.

5019

Thomson J. J.

3243

Thorsos E.

3423

Tiesinga E.

5042

Tighe $W$.

4619

Tilgner $\mathrm{J}$.

4120

Timmermans C. J.

4138

Tino G. M.

4744

Tipping R. H.

3809 
Author. Ref. No. from Part 3.

Tischer $\mathrm{H}$.

3822

Titov E. A.

3601

Titov Ye. A.

3249

Tkachev A. N.

4537,4721

Toader E. I.

3405

Toi K.

3672

Tokarev V. I.

$3323,3864,3979$

Tondello G.

$3200,3343,3355,3853$

Tonelli M.

4427,4484

Tong W. G.

4644

Toptyghin I. N.

3252

Toptygin I. N .

3105,3106

Toptygina G. I.

3575

Torres F.

4242, 4303, 4304, 4313, 4448,

4449,4521

Torres Y. F.

4450,4451

Toschek P. E.

3187,3614
Author. Ref. No. from Part 3.

Tran Minh N.

$3317,3411,3576,3757,4106$,

$4246,4593,4672$

Tran N. H.

4395

Trassy C.

3714

Trawinski R. S.

$4870,4961,4962$

Treanor C. E.

3145

Trifonov E. D.

3707

Trippenbach M.

4984

Trukhacheva V. A.

3706

Truong-Bach

$3406,3752,3753,3819,3914$,

4439,4440

Tsakiris G. D.

3836

Tserepi A. D.

5036

Tskhai N. S.

3407

Tskhai S. N.

4096

Tsoi V. I.

3915

Tsukakoshi M.

3408 
Tsukuda K.

4319

Tuganov V. F.

4243

Tumakaev G. K.

3331

Tumarkin Ya. N.

4146

Turner J. E.

3363

Turski L. A.

4283

Twitty J. T.

3577

Uchida K.

4909

Uchino K.

4705

Ueda K.

$3295,3578,3825,3916,3917$,

$3918,3919,4244,4392,5020$,

$5021,5022,5043$

Uhlenbusch $\mathrm{J}$.

$4278,4429,4843,4941$

Ullah K. N.

4844

$\mathrm{U} 1 \mathrm{~m} \mathrm{G}$.

4163

Unnikrishnan $\mathrm{K}$.

$4942,4967,5023$

Urakawa $\mathrm{H}$.

4314
Urano $\mathrm{Y}$.

$3663,3754,3838,3909,4004$, $4005,4006,4588$

Urinson A. S .

3923

Uzelac N. I.

$4522,4845,4916,5024$

Vacquie $\mathrm{S}$.

4393

Vad1a C.

$3409,3755,3797,4105,4113$,

4140,4245

Vaessen P. H. M.

4394

Vainshtein L. A.

3410,3747

Valentin A.

3626

Valentini H. B.

3756

Valiron P.

3364

Val1bona G.

4864

Vallee 0 .

$3411,3757,4106,4246,4593$,

4672,4752

Valognes J. C

$3758,3943,4417,4866,4943$

Valuzhis A. D.

3119,3120

Van Baak D. A.

3412 
Author. Ref. No. from Part 3.

Van Bergen A. R. D.

3681

Van Calcar R. A.

3920

Van de Weijer P.

4503

Van den Wi jngaart

4523

Van der Mullen J. A. M.

4826

Van der Sijde B.

4826

Van Dijk C. A.

$3230,3540,3579$

Van Engelen J. M. L.

4394

Van $\mathrm{Hal}$ R. P. M.

4407

Van Hemert M. C.

4407

Van Hulsteyn D. B.

3476

Van Linden van den Heuvell H. B. 4395

Van Regemorter $\mathrm{H}$.

$4396,4397,4524,4525,4753$

Van Rensbergen $W$.

3580

Van Uitert B. K.

3920

Van Veen E. H.

4846
Author. Ref. No. from Part 3.

Vandeplanque $\mathrm{J}$.

3093

Vanderhaegen D.

4876

Vanier $\mathrm{J}$.

$3413,3921,3922$

Vasil'eva I. A.

3923

Vasilenko L. S.

3967

Vasilevskii K. P. 3924,4247

Vasilieva I. A.

4248,4526

Vdovin Yu. A.

3131,3599

Veats S.

3690

Vedenin V. D.

4128, 4398, 4539, 4645, 4646,

4944

Vedmich V. G.

3231,3581

Veguillas J .

4683,4879

Vegvar P. de

3136

Velichanskii V. L.

3783

Velichko A. G.

3915

Velikic Z. B.

4966 
Vella M. C.

3563

Venkatesan $\mathrm{T}$.

3759

Verges $\mathrm{J}$.

$3156,3630,3631,4107,4969$

Verhaar B. J.

4647,5042

Verma R.

4108

Vetter R.

$3232,3582,3757,3760$

Veza D.

$3583,3584,3761,3796,3925$,

$4109,4110,4754$

Veza D.

3233

Vicharelli P. A. 4111

Vickers T. J.

4821

Vienne-Casalta D.

3585,3926

Viladrosa R.

3174

Vince I.

$4399,4400,4401,4847,4848$

Vinogradov A. V.

3619

Viöl W.

4843,4941

Visticot J . P .

$3465,3559,3560,3644,3751$,

$3762,3763,4402,4441,4442$
Vitel Y.

$4648,4649,4650,4755,4756$

Vitrant G.

3739

Vlasov A. N.

4403

Vogel. N.

5025

Voigt P.

3549

Volk C. H.

3963

Volkova L. M.

3586

Volonté S.

$3234,3256,3257,3720$

Von Borstel $M$.

4651

Von Goeler S.

3264,3618

Voslamber D.

$3402,3587,3740,3764,3765$,

$3766,3779,3927,4404,4506$,

$4527,4528,4529,4841,4936$

Vrakking J. J. A. M.

4425, 4555

Vrhovac S. B.

4966

Vujicic B.

5002

Vujicic B. T.

3803, 4112, 4249, 4405, 4801, 4849 
Vujnovic $\mathrm{V}$.

$3087,3409,3584,4113$

Wackherr P.

3367

Wada A.

4805

Wagner A.

3759

Walder V. S.

$3432,3598,3603,3791,3801$

Walker Z. H.

4550

Walkup R.

4250

Walkup R. E.

$3588,3767,3768,3928,4082$

Walters P. E.

4530

Walther $\mathrm{H}$.

4367

Wang J. S .

$4850,4907,5044$

Wang J. - S .

4908

Wang S. Y.

3150,3414

Wang W. J.

4008,4114

Wang $\mathrm{Z}$.

4855

Ward J. M.

3318
Wareing D. P.

4322

Warrington D. M.

4262

Wasilewski J.

3439

Wasserman K. R.

4857

Waszink J. H.

3235,3236

Watanabe $Y$.

3415

Watkin G.

4322

Wawrzynski J .

$3953,3954,4273,4531,4652$

Weber E. W.

$3416,3417,3769,3770,3771$,

$3772,3773,4016,4115$

Weber K. H.

$3418,3419,3929,3930,4116$

Weber K. - H.

4011

Weber P. G.

3472

Weckström $\mathrm{K}$.

3567

Wehenke1 C.

3312,3313

Wehrse R.

4860

Weinberger $\mathrm{E}$.

$3403,3569,3749,4642,4643$ 
Author. Ref. No. from Part 3.

Weirauch $\mathrm{T}$.

4806

Weisheit J . C.

$3420,3787,4370$

Wende $B$.

$3177,3654,3989,4302,4432$

Weniger $\mathrm{S}$.

$3378,3829,3830,3994,4452$, 4583

Werner $\mathrm{H}$.

4017

Werner $\mathrm{K}$.

4251

West P. J.

$4700,4939,5018$

Wetzer J. M.

4252

Wexler B. L.

3589

Whitney K. G.

3931

Whittaker E.

3525,3715

Whittal D. M.

4997

Whitten B. L.

4187,4204

Whittingham I, B.

5003

Wiegart N. J.

$3421,4117,4118$

Wieman C.

4751
Author. Ref. No. from Part 3.

Wiese W. L.

$3096,3099,3237,3316,3932$,

$4033,4189,4196,4197,4468$,

$4596,4917,5045$

Wilcomb B. E.

3589

Wilczek E.

3774

Wildman D. W.

3590

Wilksch P. A.

4406

Williams P. F.

3457

Williams R. R.

4119

Windhol $\mathrm{z}$ L.

3591,4757

Winefordner J. D.

$3540,4923,5000$

Wineland D. J .

3677,3851

Winfield R. J.

$4344,4345,4346$

Wing $W . H$.

3643

Winkelmann $G$.

4120

Wirsig M.

4017, 4181

Wirz P.

3475 
Author. Ref. No. from Part 3.

Wodkiewicz K.

3775

Woerdman J. P.

$3422,4407,4635$

Wolnikowski J.

$3140,3141,3341,3438,3512$,

$3933,4059,4205,4273,4276$,

$4354,4423,4531,4532,4652$,

$4870,4945,4961,4962$

Woltz L. A.

$3683,3776,3934,4121,4253$,

4284, 4468, 4533, 4598, 4619,

4758, 4759, 4902, 4906, 4999,

5026

Woodworth M. R.

4122

Wormhoudt J. C.

4101

Woschnik T.

4573

Wray J. E.

4896

Wright E. L.

4141

Wright $\mathrm{J}$.

3743

Wright J J .

3790

Wu C. Y. R.

$3238,3239,3240,3777$

Wurster W. H.

3145

Xu E. Y.

4534
Author. Ref. No. from Part 3.

Xu G. $-\mathrm{X}$.

4643

$\mathrm{Xu}$ X. J .

4794,4905

Yaakobi B.

3423,3592

Yablochkov E. Yu.

3241

Yakolev D. G.

4719

Yakovlenko S. I.

$3935,4143,4537,4721$

Yakovlev D. G .

$3952,4060,4819,4851$

Yakovson N. N.

4261

Yamaguchi N.

3651,4007

Yamamoto $\mathrm{K}$.

$3593,3594,3778,4123$

Yan X. Z .

4535,4536

Yanagisawa $\mathrm{T}$.

4005, 4006

Yang B. $-\mathrm{X}$.

4353

Yang J .

4760

Yang $X$. D .

4940

Yasevich V. Yu.

$4418,4719,4819,4851$ 
Author. Ref. No. from Part 3.

Yatsenko L. P.

3127

Yazenkov V. V.

4126

Yeh S.

3424

Yelnik J.-B.

3779

Ying-Jian $W$.

4254

Yonehara A.

3497,3856

Yoshida E.

4938

Yoshihara K.

4494

Young J. P.

3199

Yukov E. A.

$3410,3747,4424,4666,4772$

Yurkin E. K.

3783

Zagrebin A. L.

4779, 4852, 4853, 4854, 4946, 4947

Zaibi M. A.

4866

Zaidi A. A.

4869

Zakaraya M. G .

4408

Zaprianova $\mathrm{R}$.

3780
Author. Ref. No. from Part 3.

Zarovnyaev G. V.

4124

Zarro D. M.

4409

Zatsepa L. F.

3130

Zeegers P. J. Th.

3230

Zeeman P. B.

4530

Zemtsov Yu. K.

4256,4863

Zhang J. - Y.

4760

Zhang $\mathrm{Z}$.

4855

Zhechev D.

3780

Zhi G.

4653

Zhidkov A. G.

$4410,4537,4856$

Zhiglinskii A. G.

3429

Zhou H. - T .

4760

Zhu X.

4538,4761

Zhuk V. P.

3595

Zhuvikin G. V.

$3425,3936,4411$ 
Zhuzhunashvili A. I.

3125

Zibrov A. S .

3783

Zimmermann J. P. 3828

Zimmermann J.-P. 3993

Zimmermann $M$.

3781

Zimmermann $\mathrm{R}$.

4464

Zirin $\mathrm{H}$.

4409

Zoellner M. J .

4226

Zokai M.

4589,4654

Zolotarev M. S.

4769

Zon B. A.

4771

Zughul M. B .

3607

Zugravescu P. Gh.

4693 


\section{ERRATA}

Reference

No.*

2760

2913

2996

3058

3061

3075
Corrections or Additions to NBS Special Publication 366, Supplement 3 (1978)

In Part 2, add the classification of Na I (Stark, T).

In Part 3, change the reference to the English translation: Sov. Phys.--JETP 46, 209 (1977).

In Part 1, add the classification of 1.6.4. In Part 2, delete $\mathrm{Na}$ I and $\mathrm{K}$ I (Stark, E).

In Part 1, add the classification of 1.4.3. (E).

In Part 1, add the classification of 1.1.2.2. (T).

In Part 1, add the classification of 1.3.4. (E).

*The numbers refer to paper identification numbers of Part 3 of the third supplement to the original bibliography. 




\section{Periodical}

Journal of Research of the National Institute of Standards and Technology-Reports NIST research and development in those disciplines of the physical and engineering sciences in which the Institute is active. These include physics, chemistry, engineering, mathematics, and computer sciences. Papers cover a broad range of subjects, with major emphasis on measurement methodology and the basic technology underlying standardization. Also included from time to time are survey articles on topics closely related to the Institute's technical and scientific programs. Issued six times a year.

\section{Nonperiodicals}

Monographs-Major contributions to the technical literature on various subjects related to the Institute's scientific and technical activities.

Handbooks - Recommended codes of engineering and industrial practice (including safety codes) developed in cooperation with interested industries, professional organizations, and regulatory bodies.

Special Publications - Include proceedings of conferences sponsored by NIST, NIST annual reports, and other special publications appropriate to this grouping such as wall charts, pocket cards, and bibliographies.

Applied Mathematics Series-Mathematical tables, manuals, and studies of special interest to physicists, engineers, chemists, biologists, mathematicians, computer programmers, and others engaged in scientific and technical work.

National Standard Reference Data Series - Provides quantitative data on the physical and chemical properties of materials, compiled from the world's literature and critically evaluated. Developed under a worldwide program coordinated by NIST under the authority of the National Standard Data Act (Public Law 90-396). NOTE: The Journal of Physical and Chemical Reference Data (JPCRD) is published bimonthly for NIST by the American Chemical Society (ACS) and the American Institute of Physics (AIP). Subscriptions, reprints, and supplements are available from ACS, 1155 Sixteenth St., NW, Washington, DC 20056.

Building Science Series-Disseminates technical information developed at the Institute on building materials, components, systems, and whole structures. The series presents research results, test methods, and performance criteria related to the structural and environmental functions and the durability and safety characteristics of building elements and systems.

Technical Notes - Studies or reports which are complete in themselves but restrictive in their treatment of a subject. Analogous to monographs but not so comprehensive in scope or definitive in treatment of the subject area. Often serve as a vehicle for final reports of work performed at NIST under the sponsorship of other government agencies.

Voluntary Product Standards-Developed under procedures published by the Department of Commerce in Part 10, Title 15, of the Code of Federal Regulations. The standards establish nationally recognized requirements for products, and provide all concerned interests with a basis for common understanding of the characteristics of the products. NIST administers this program in support of the efforts of private-sector standardizing organizations.

Consumer Information Series - Practical information, based on NIST research and experience, covering areas of interest to the consumer. Easily understandable language and illustrations provide useful background knowledge for shopping in today's technological marketplace.

Order the above NIST publications from: Superintendent of Documents, Government Printing Office, Washington, DC 20402.

Order the following NIST publications-FIPS and NISTIRs-from the National Technical Information Service, Springfield, VA 22161.

Federal Information Processing Standards Publications (FIPS PUB) - Publications in this series collectively constitute the Federal Information Processing Standards Register. The Register serves as the official source of information in the Federal Government regarding standards issued by NIST pursuant to the Federal Property and Administrative Services Act of 1949 as amended, Public Law 89-306 (79 Stat. 1127), and as implemented by Executive Order 11717 (38 FR 12315, dated May 11, 1973) and Part 6 of Title 15 CFR (Code of Federal Regulations).

NIST Interagency Reports (NISTIR) - A special series of interim or final reports on work performed by NIST for outside sponsors (both government and non-government). In general, initial distribution is handled by the sponsor; public distribution is by the National Technical Information Service, Springfield, VA 22161, in paper copy or microfiche form. 

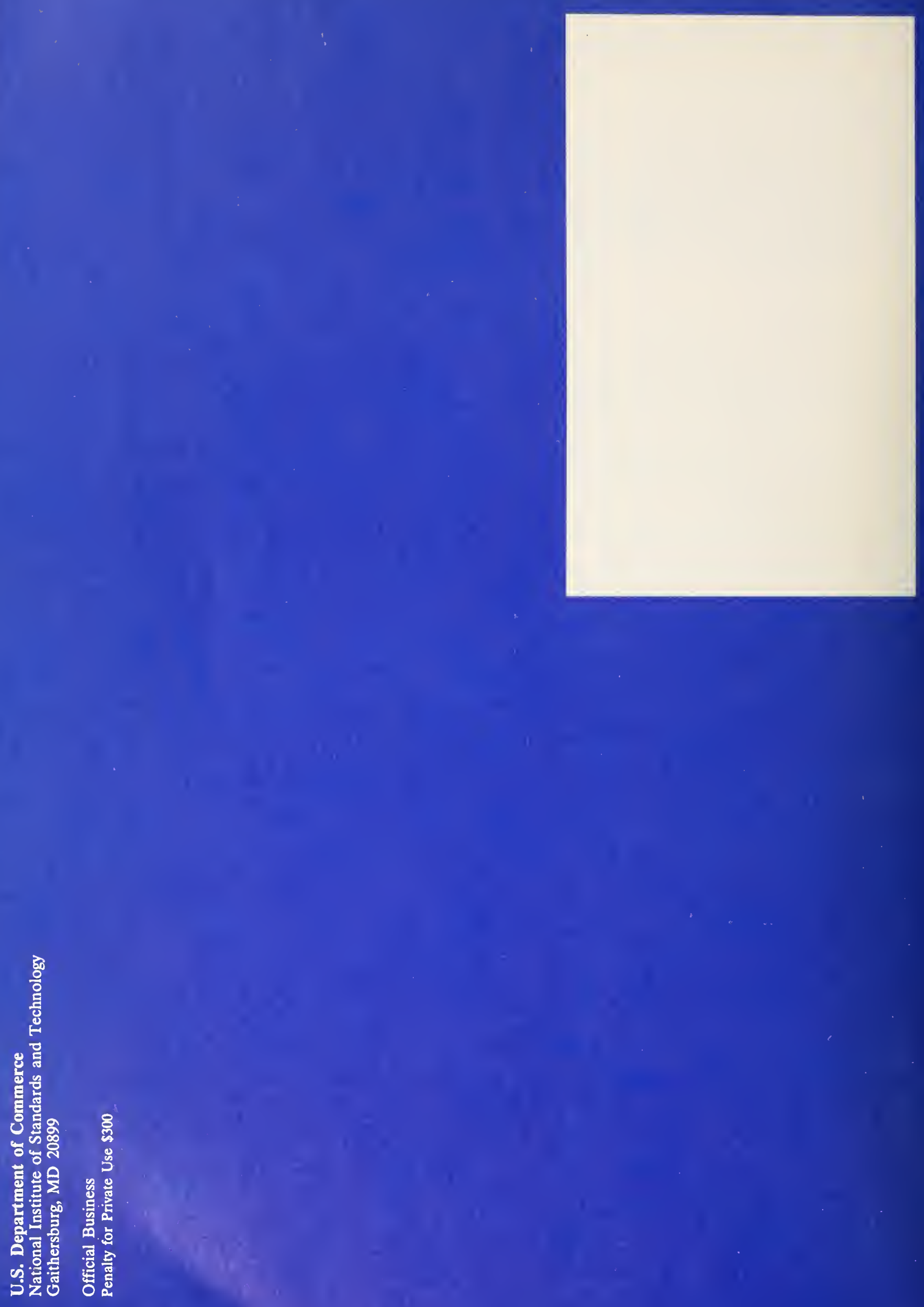